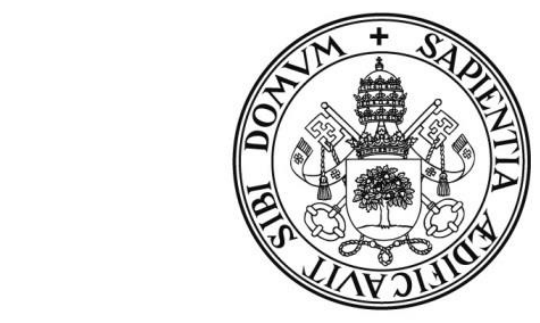

Universidad deValladolid

FACULTAD DE CIENCIAS

DEPARTAMENTO DE FÍSICA APLICADA

TESIS DOCTORAL:

\title{
OPTIMIZATION OF NANOFILTRATION MEMBRANE PROCESSES APPLIED TO GRAPE MUST FOR THE PRODUCTION OF LOW ALCOHOL WINES
}

Presentada por Camila Mariana Salgado Faller para optar al grado de doctora por la Universidad de Valladolid

Dirigida por:

D. Pedro Prádanos del Pico

Dña. Laura Palacio Martínez 





\title{
(․ㅜ \\ Universidad deValladolid
}

\author{
Dr. Pedro Prádanos del Pico \\ Catedrático del Departamento de Física Aplicada \\ Universidad de Valladolid \\ y \\ Dr. Laura Palacio Martínez \\ Profesora Titular del Departamento de Física Aplicada \\ Universidad de Valladolid
}

Certifican que:

como directores de la Tesis Doctoral titulada "OPTIMIZATION OF NANOFILTRATION MEMBRANE PROCESSES APPLIED TO GRAPE MUST FOR THE PRODUCTION OF LOW ALCOHOL WINES" presentada por D." Camila M. Salgado Faller, alumna del programa de doctorado en Ingeniería de Procesos y Sistemas, impartido por la Universidad de Valladolid, autorizan la presentación de la misma, considerando que el trabajo presentado constituye su tesis para optar al grado de Doctor, ya que se trata de un trabajo original y todos los resultados presentados y los análisis realizados son fruto de su investigación.
Valladolid, a de
de 2015

Fdo. Pedro Prádanos del Pico

Fdo. Laura Palacio Martínez 

Por dónde empezar? Esta parte es tan difícil.... No quiero olvidar nada ni a nadie.

Primero quiero agradecer al Ministerio de Educación Español por la beca FPU (AP2010-5769) que me fue otorgada para realizar este doctorado durante todos estos años. Quiero agradecer a la Universidad de Valladolid (UVa) por las becas que me concedió para realizar mis dos estancias de doctorado, dos experiencias maravillosas en todo sentido.

Quiero agradecer también a mis dos directores: Pedro y Laura por todo su apoyo. Han sido grandes mentores, consejeros y amigos a lo largo de este doctorado y experiencia de vida... simplemente gracias por todo!

A Antonio, por tratarme siempre como un igual a pesar de que siempre tuviste que orientarme!

A Encarna, por la colaboración y apoyo en Palencia. Sin ella esto no hubiera sido posible.

A todo el SMAP: Sarita, Moni, Alberto, Vero, Pedro, Laura, Antonio y José Ignacio son un grupo de investigación y de amigos espectacular!!!

Thanks to Carla Brazinha and Joao Crespo for giving me the oportunity of doing part of my research at the Requimte (Universidade Nova de Lisboa) and also for being such great friends.

A want to thank also Roland Haseneder, Dr. Repke and all my friends at the ITUN (TU Bergakademie Freiberg) for all your help and support during that wonderful second internship

A lo largo de estos años he mantenido grandes amistades que la distancia no logró debilitar y que no puedo dejar de agradecer. A mis bell@s amig@s en la Argentina, que han sido un gran apoyo y motivo de alegría siempre. Mis amig@s en Bolivia, esas personas maravillosas que hace una eternidad amo y adoro. Todas estas amistades son las que me hacen sentir feliz de haber vivido en distintas ciudades y son aquellas por las que no puedo inclinarme hacia una nacionalidad.

Pero durante estos cinco últimos años he hecho grandes amigos en España. Mi gran comisión de ocio: Victor, Julián, Pinto, Dani, Ana, Sori, Cris, ese manicomio portátil de personitas maravillosas y especiales que me llevaron a la cordura. Las chicas del mundo que conocí gracias al máster y que me acompañaron y soportaron a lo largo de taaaanto: Bea, Mafe, Pami, Marthy y Maria Eugenia....Gracias! Katia, mi gran amiga y compañera en este doctorado....No puedo dejar de mencionar a mis 
argentinitos: Gloriani y Gonzalez! Una pareja divina que me devolvió el sentido de familia a pesar de estar tan lejos. Carla, no me alcanzan las palabras para agradecer y agradecerte el haberlos conocido!

A Amado, ese gran guía personal y espiritual que me reorientó especialmente en la parte final de esta experiencia

Por último quiero agradecer a mi familia: Mamá, Papá, Rodrigo, Ignacio, Mamina, Otto, Eli, Xime, Cande, Fran, Vingy y nuestro nuevo Felipe! Cada uno de ustedes a su manera me acompañó y apoyó para salir adelante en este periodo tan importante. Agradezco a la distancia y experiencia por permitirme aprender que son lo más grande que tengo, lo que nada ni nadie podrá quitarme jamás pase lo que pase. Los amo!!!

Gracias a todos. Gracias por ser, gracias por aparecer y gracias por estar! 


\section{TABLE OF CONTENTS}

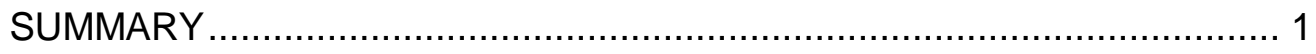

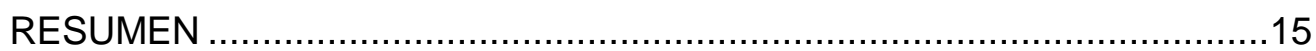

Section I. Introduction and general methodology ................................27

Chapter 1. From Grapes to wine. Analysis of current situation ...................31

1.1 Problematic and Motivation: Influence of climate change on grape maturation and wine quality................................................................... 31

1.2 Alcohol control techniques used in the grape and wine industry..........32

1.3 Grape must and its composition .......................................................35

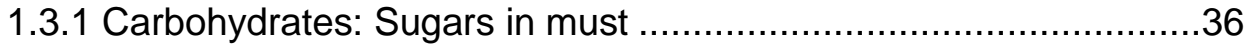

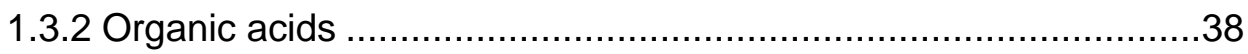

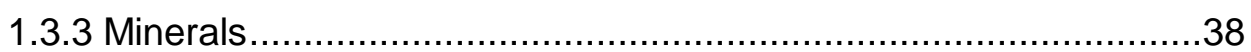

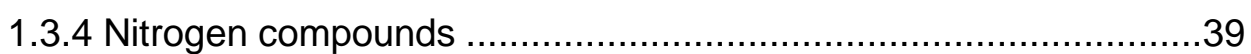

1.3.5 Phenolic compounds ............................................................40

1.3.6 Aromatic compounds ......................................................... 41

1.3.6.1 Terpens, Carotenoids and pyrazines ....................................41

1.3.6.2 C6-alcohols and aldehydes ...............................................42

1.4 Aims and outline of the PhD thesis...............................................43

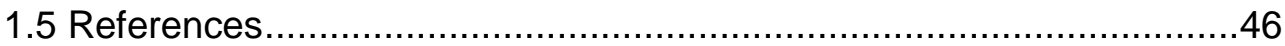

Chapter 2. Nanofiltration and Pervaporation membrane processes............51

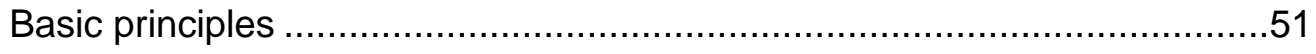

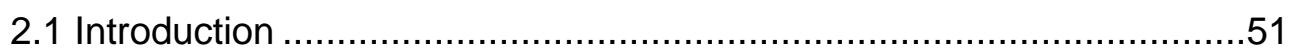

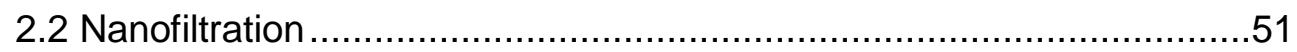

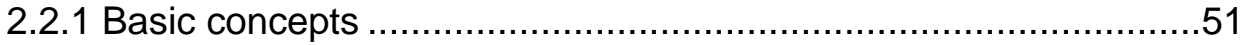

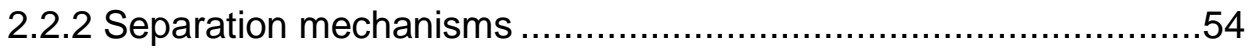

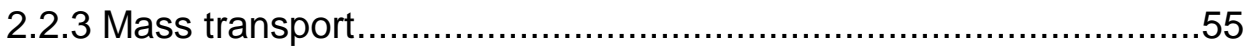

2.2.4 Concentration Polarization. Film Theory ....................................56

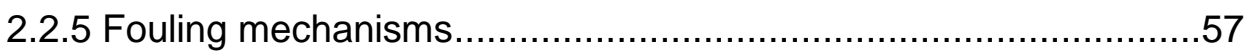

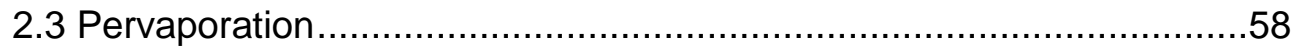

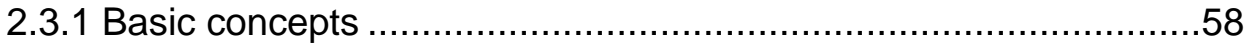

2.3.2 Mass transport. Solution - diffusion theory ............................60

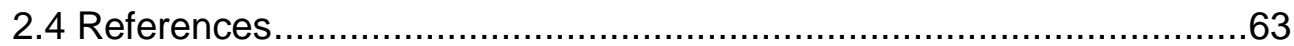


Section II. Permeate flux decrease during the nanofiltration of grape juice.

Study of the influence of the different molecular weight compounds.

Chapter 3. Influence of low and high molecular weight compounds on the permeate flux decline in nanofiltration of red grape must 71

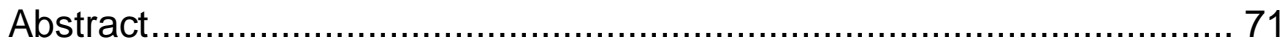

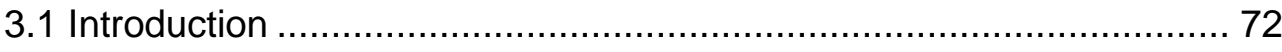

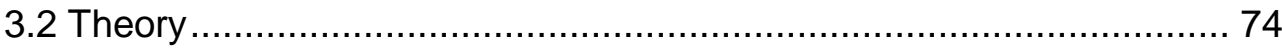

3.2.1 Permeate Flux Limit........................................................... 74

3.2.2 Concentration Polarization. Film Theory .................................. 76

3.2.3 Fouling mechanism and models .......................................... 77

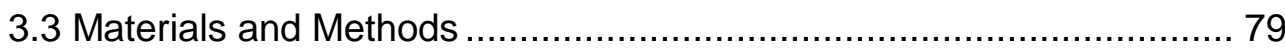

3.3.1 Membrane and Experimental Setup......................................... 79

3.3.2 Synthetic Solution and Must .............................................. 81

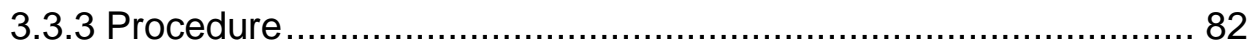

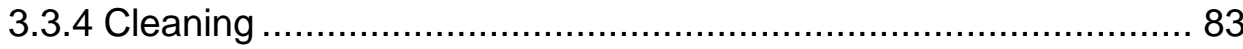

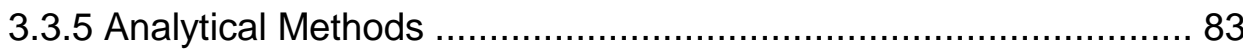

3.4 Results and Discussion .......................................................... 84

3.4.1 Nanofiltration Processes ........................................................ 84

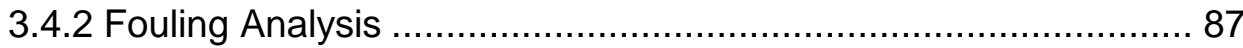

3.4.3 Evolution of concentration of sugars and membrane efficiency.... 88

3.4.4 Determination of the resistances to the permeate flux ................ 91

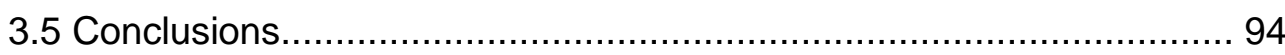

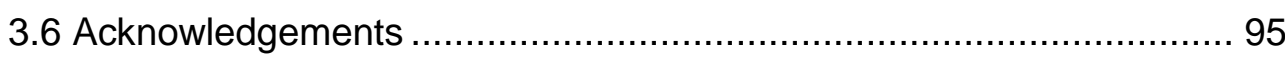

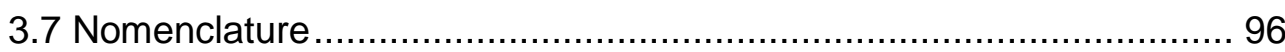

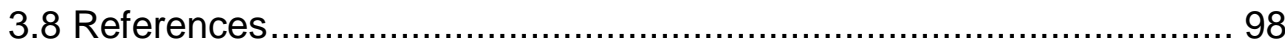

Chapter 4. Fouling study of Nanofiltration membranes for sugar control in grape must. Analysis of resistances and the role of osmotic pressure ...... 105

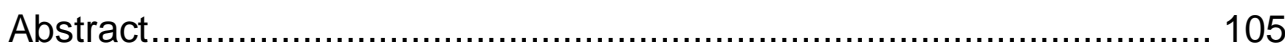

4.1 Introduction ............................................................................ 106

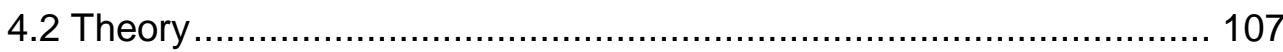

4.2.1 Permeate flux decrease and retention model ...................... 107

4.2.2 Fouling mechanisms ................................................... 108

4.2.3 Pressure drops along the membrane system ....................... 109

4.2.4 Specific cake resistance. Principles of cake filtration. .............. 110 
4.2.5 Pore size evolution

4.3 Materials and methods ........................................................113

4.3.1 Membranes and experimental set-up ..................................113

4.3.2 Synthetic solution and commercial grape must........................114

4.3.3 Experimental protocol ........................................................114

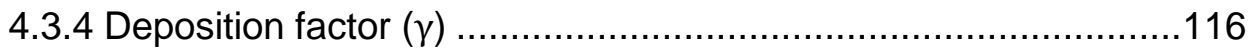

4.3.5 Analytical methods .......................................................116

4.3.6 SEM and AFM microscopy .............................................116

4.4 Results and discussion............................................................ 117

4.4.1 Permeate flux and permeability ...........................................117

4.4.2 Sugars retention and passage ..............................................118

4.4.3 Analysis of the fouling mechanisms ....................................120

4.4.4 Microscopy .................................................................. 122

4.4.5 Resistances to the permeate flux......................................123

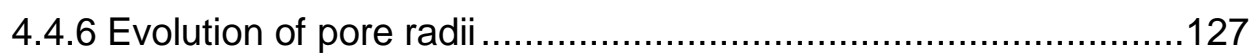

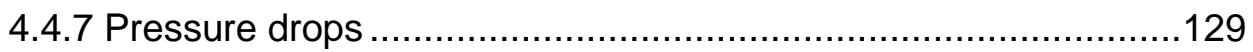

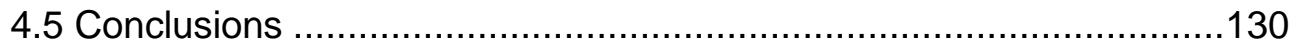

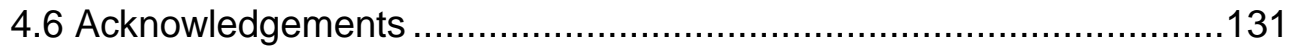

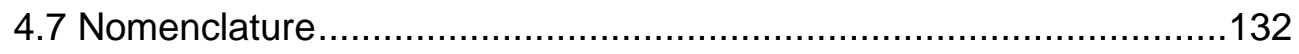

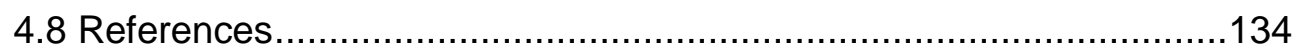

4.9 Supplementary Material .........................................................138

Section III. Scale-up a of nanofiltration process for sugar reduction of grape must. Elaboration of low alcohol content wines 139

Chapter 5. Comparative Study of Red Grape Must Nanofiltration: Laboratory and Pilot Plant Scales ..................................................................143

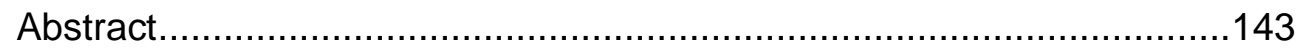

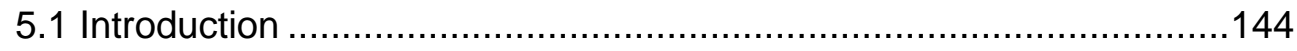

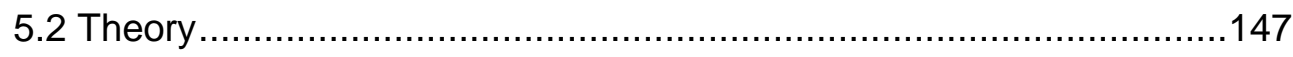

5.2.1 The Spiral Wound Module ................................................. 147

5.2.1.1 Flow conditions in a Spiral Wound Module...........................147

5.2.1.2 Mass- transport in spacer-filled channels ..............................149

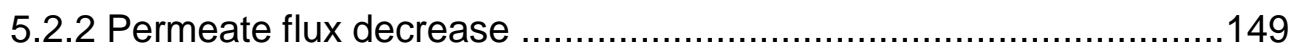

5.2.3 Concentration Polarization. Film theory .................................150

5.2.4 Fouling mechanism. Cake Filtration..........................................151 
5.2.5 Retention model 151

5.3 Materials and Methods ........................................................ 152

5.3.1 Membrane and Experimental Set-up .................................. 152

5.3.2 Must ................................................................................... 153

5.3 .3 Procedure .................................................................... 154

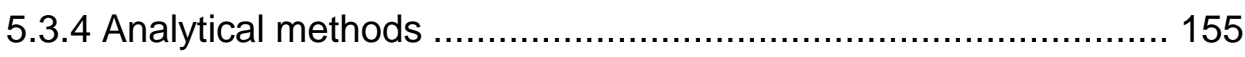

5.4 Results and Discussion ........................................................... 156

5.4.1 Permeate flux evolution .................................................... 156

5.4 .2 Efficiency of the spiral wound module ................................... 157

5.4.2.1 Analysis of the filtrated musts ......................................... 157

5.4.2.2 Sugars rejection ......................................................... 158

5.4.3 Resistance to the permeate flux .......................................... 159

5.4.4 Fouling mechanism ............................................................ 162

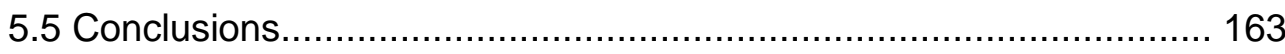

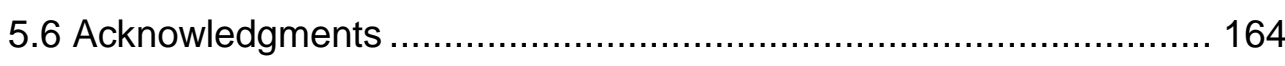

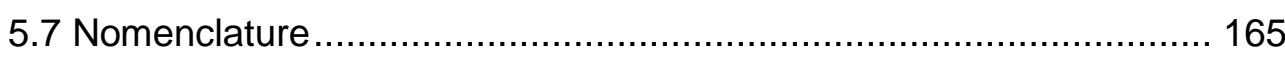

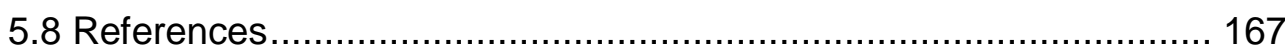

Chapter 6. Alcohol reduction in red and white wines by nanofiltration of musts before fermentation ............................................................... 173

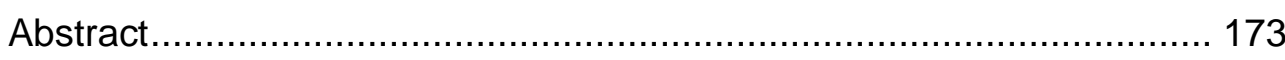

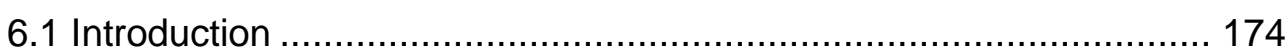

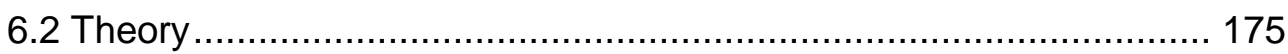

6.3 Materials and Methods ............................................................... 176

6.3.1 Membrane and experimental set-up ..................................... 176

6.3.2 Grape musts ............................................................... 177

6.3.3 Procedure .................................................................. 178

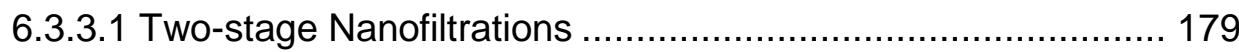

6.3.3.2 Single-stage Nanofiltration ................................................ 180

6.3.4 Winemaking process .................................................. 181

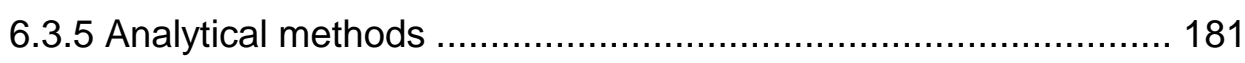

6.3.6 Consumer sensory test .................................................. 182

6.4 Results and discussion.......................................................... 183

6.4.1 Nanofiltration processes .................................................... 183 


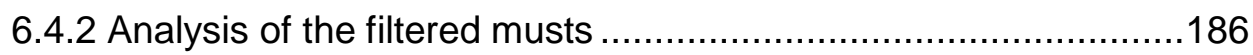

6.4.3 Production and analysis of wines.........................................189

6.4.4 Chemical and sensory characteristics of the resulting wines ......191

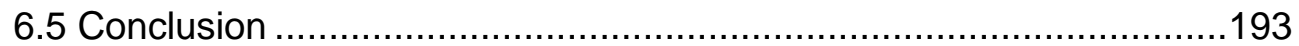

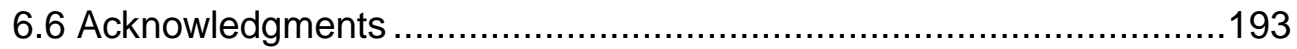

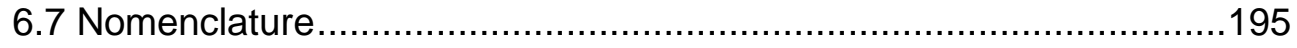

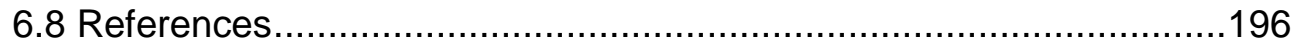

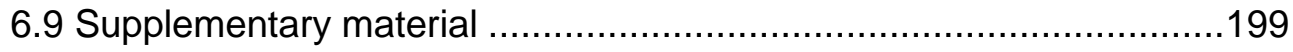

Section IV. Aroma recovery of grape must using pervaporation. elaboration of a full flavored low alcohol content wine

Chapter 7. Experimental investigation of pervaporation membranes for aroma recovery in white grape must..................................................207

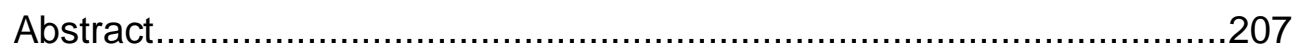

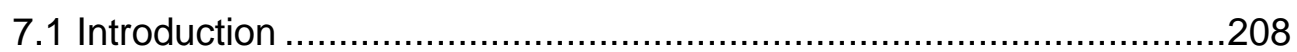

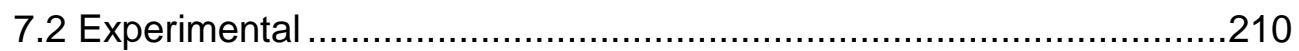

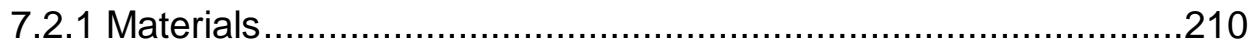

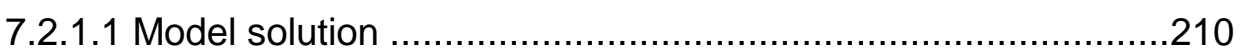

7.2.1.2 Verdejo Grape Juice ....................................................210

7.2.1.3 Membranes tested ............................................................211

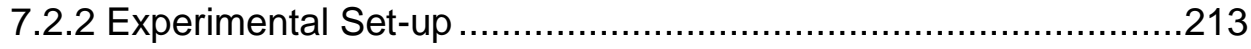

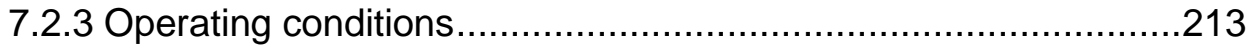

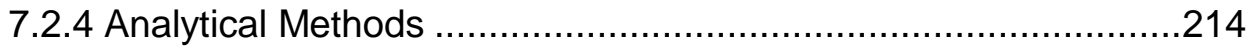

7.2.5 Methods of Calculation ...................................................215

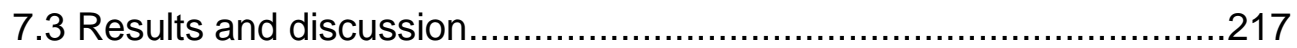

7.3.1 Model solution experiments ...................................................217

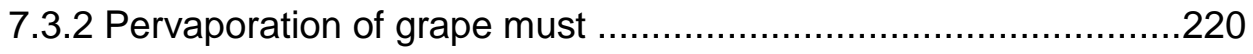

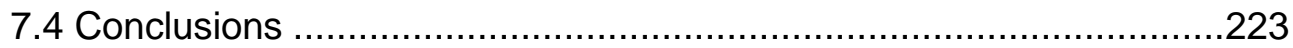

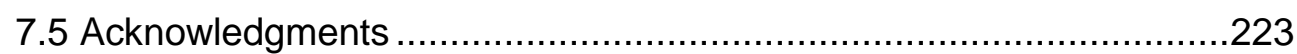

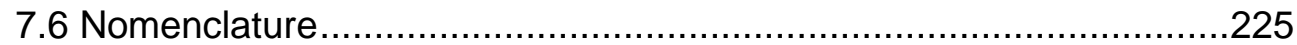

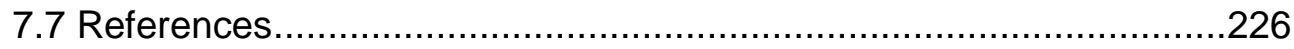

Chapter 8. Application of pervaporation and nanofiltration membrane processes for the optimization of sugar reduction in grape must in order to produce a full flavored low alcohol content wine 


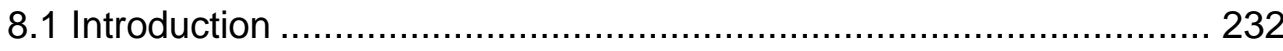

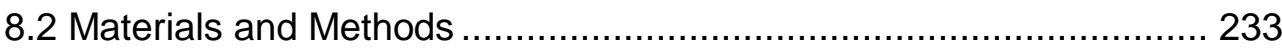

8.2.1 Pervaporation experimental set up ..................................... 233

8.2.2 Nanofiltration experimental set up........................................ 234

8.2.3 Verdejo white grape must ................................................... 235

8.2.4 Experimental Procedure ........................................................... 236

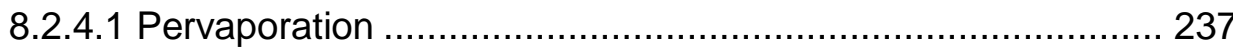

8.2.4.2 Two-stage nanofiltration................................................... 237

8.2.5 Elaboration of the corresponding wines ................................. 239

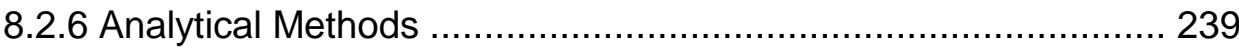

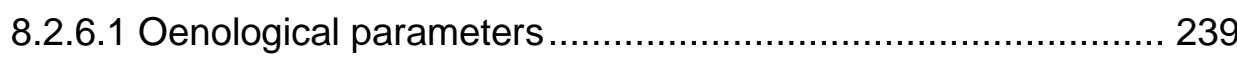

8.2.6.2 Volatile compounds......................................................... 240

8.2.7 Consumer sensory test...................................................... 241

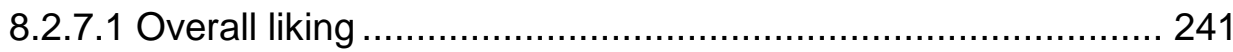

8.2.7.2 Intensity scales .......................................................... 242

8.2.7.3 Projective mapping ........................................................ 242

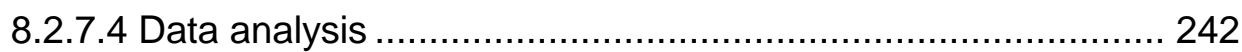

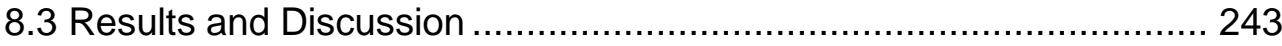

8.3.1 Pervaporation experiments .............................................. 243

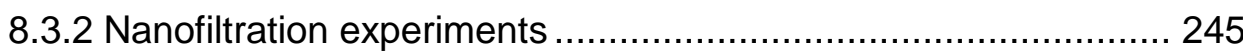

8.3.3 Analysis of the resulting musts ............................................ 247

8.3.4 Production and chemical analysis of wines ............................. 249

8.3.5 Sensory characteristics of the resulting wines ........................ 250

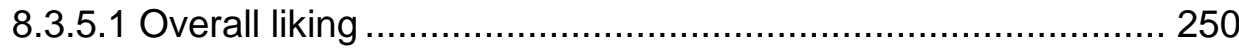

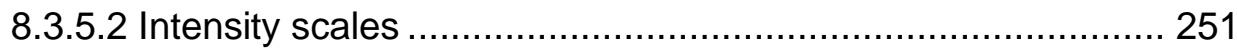

8.3.5.3 Projective mapping ................................................... 252

8.3.6 Aromatic profile of the resulting wines .................................... 252

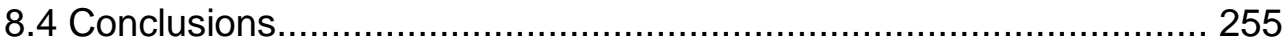

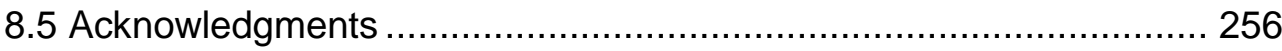

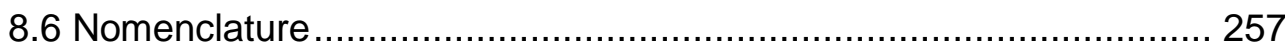

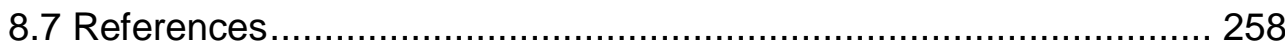

8.8 Supplementary material......................................................... 260

Section V. Main conclusions \& future work ........................................... 261 
Conclusions.

Future directions.. 

SUMMARY 



\section{SUMMARY}

As it is widely known, most of the compounds that determine the sensory characteristics of wines are produced during the ripening of grapes. Along this period, the concentration of sugars, aminoacids, phenolic compounds and potassium increase, while the content of organic acids, particularly malic acid, decreases. These changes do not necessarily occur simultaneously and therefore winemakers need to consider the technological maturity (i.e. sugar content and acidity), and also the phenolic (especially anthocyannins and tannins) and aroma maturity of grapes in order to set the harvest date.

Along the last years, due to climate change, various world winemaking regions have provided evidence of modified vine development and fruit maturation patterns as a consequence of global warming. Among the most important climate change-related effects there is a higher sugar content, lower acidities and modification of varietal aroma compounds. Fermentation of this must leads to alcoholic degrees higher than desired, as they may be too burning in the mouth and mask the fruity aromas and taste of wine. Premature grape harvest and winemaking should affect the final wine quality, leading to more acid and less colored wines, because the phenolic maturity would not be yet fully achieved. A commendable oenological practice establishes that the quality of wines depends essentially on the maturity of phenolic components contained in the grape berries. Therefore, in order to produce a full flavored wine, the harvest should be carried out in the optimum ripeness of the fruits and then innovative techniques to reduce the final alcohol content should be applied.

Winemakers have applied these methods mainly to two different sources: wine and grape must. The most used dealcoholisation method in the industry is the spinning cone column (SCC) for the separation of volatile components from liquids and slurries. This procedure requires several steps to remove first the wine aromas and afterwards alcohol and finally the aromas are returned to the dealcoholized wine. Because it is a time consuming and expensive process, other dealcoholization techniques have been used too. Some examples are the thermal processes such as distillation columns, evaporators, or freeze concentration. Heat-based processes can produce wines with very low alcohol content, however most of the volatile aroma compounds are also lost during the ethanol removal. Reverse osmosis $(\mathrm{RO})$ is also used to reduce alcohol in wines, but the problem is that $\mathrm{RO}$ membranes are permeable to both alcohol and water, and after the filtration it is necessary to add water again to the dealcoholized wine. This creates legal problems in some countries where the addition of water is 
forbidden by law. Membrane processes, namely dialysis, pervaporation and vacuum membrane distillation are also being used to get low-alcohol drinks.

An adequate control of sugars in musts can also be useful to obtain low alcohol degree wines. Examples of this are the use of enzymes or yeasts that use sugars for cell growth. However these methods also produce high levels of microbiological side products such as gluconic acid or esters which alter the sensory quality of the resulting wine.

Processes involving membranes have also been used for reducing the sugar content. If the molecular weight of sugars in must is taken into account, nanofiltration (NF) should be the membrane process to be chosen to control them. Several studies have revealed the feasibility of NF for sugar control in grape must and the alcohol reduction of the resulting wine. However, a slight loss of color and aroma intensity and a slender unbalancing of some important substances (potassium, malic and tartaric acid) were detected. Moreover, these experiments of must nanofiltration, showed that there are some problems that are common in membrane separation processes, among them especially relevant trouble is caused by fouling and the permeate flux decline.

For all these reasons, the main scope of this $\mathrm{PhD}$ thesis is to optimize the nanofiltration process for sugar control in grape must in order to produce full flavored wines with reduced alcohol content. For this purpose different aspects had to be evaluated and studied.

First of all, it was intended to analyze the reduction of the nanofiltration permeate volume flux $\left(J_{v}\right)$ due to fouling, resistances $\left(R_{j}\right)$ and osmotic pressure generated by the different compounds present in must. In that sense, a detailed method for the study of the individual influence in must NF of its main low and high molecular weight compounds (LMW and HMW respectively) was developed. For this purpose a synthetic solution containing the typical LMW of natural must, namely glucose, fructose, malic and tartaric acids, potassium, sodium, calcium and magnesium was nanofiltered. The results were compared with those obtained from the filtration, under the same operation conditions, of commercial red must; which, besides the already mentioned solutes, contains HMW such as polyphenols, polysaccharides and proteins. Experiments were carried out at laboratory scale using a NF270 flat sheet membrane from Dow Filmtech in a crossflow module. The rapid formation and thickening of the gel layer on the membrane surface, during must filtration caused extreme conditions of analysis: small increase in the concentration of sugars in the retentate and rapid decline in $J_{v}$, obtaining a small volume of permeate. In spite of this, the analytical method proposed enabled the individual study of the resistances and fouling mechanism generated by LMW and HMW. The results proved that HMW have 
more influence on the permeate flux decrease since they are the main responsible of the fouling phenomenon (cake filtration fouling mechanism), while LMW contribute to the flux decay mostly through an increase of osmotic pressure during the process. Regarding the resistances generated individually by LMW and HMW $\left(\mathrm{R}_{\mathrm{fLMW}}\right.$ and $\mathrm{R}_{\mathrm{fHMW}}$ respectively) two different evolutions were observed. $R_{\mathrm{fLMW}}$ remained practically constant in comparison to the $\mathrm{R}_{\mathrm{fHMW}}$ which increased progressively until reaching a maximum, beyond which there is a progressive slight decrease. The decay of $R_{\mathrm{fHMW}}$ at the end of the red must filtration suggested that the cake formed may be compressible causing an osmotic pressure increase which reduces the effective pressure drop across the cake and so its resistance to $J_{v}$. Moreover, the formation of the gel layer on the membrane surface changed the selectivity to sugars, but the compression of this cake increases the retention even more.

According to these results, the next issue to be assessed consisted on the selection of the most suitable NF membrane. It should show an appropriate sugars retention (pore size), about 50\%, and a low affinity to HMW (manufacturing polymer) in order to maintain substantially unaltered its retention characteristics due to the accumulation of these substances on the membrane surface. In this sense, the method previously proposed was used for the systematical study and comparison of different NF membranes. The parameters evaluated were membrane fouling, resistances to permeate flux and osmotic pressure gradients through the membrane system generated individually by LMW and HMW during grape must filtration. Here, the performance of three flat sheet NF membranes was studied: NF270, from Dow Filmtech; HL, from GE: Water \& Proccess technologies, and KMS SR3 from Koch Membrane Systems. Figure 1a shows that, for the three membranes, the kinetics of fouling when HMW compounds were present included three consecutive steps: pore blocking followed by cake deposition and an increase in compression until arriving to compaction (arrows in Figure 1a). Moreover, it was observed that while the cake was being assembled, sugar retention increased and arrived to a maximum when the cake was completely built. During the process, the osmotic pressure of the system increased and the effective pressure decreased in the three membranes. Once again, $R_{f H M w}$ increased progressively until reaching a maximum beyond which a gradual small decrease was observed. Figure $1 \mathrm{~b}$ shows the comparison of the resistances due to fouling for the three membranes studied. Relating the cake fouling mechanism with this resistances analysis for the three membranes it was observed that, the maximum $R_{\mathrm{fHMW}}$ agreed fairly well with the beginning of the third fouling mechanism, where the cake starts to be compacted. 

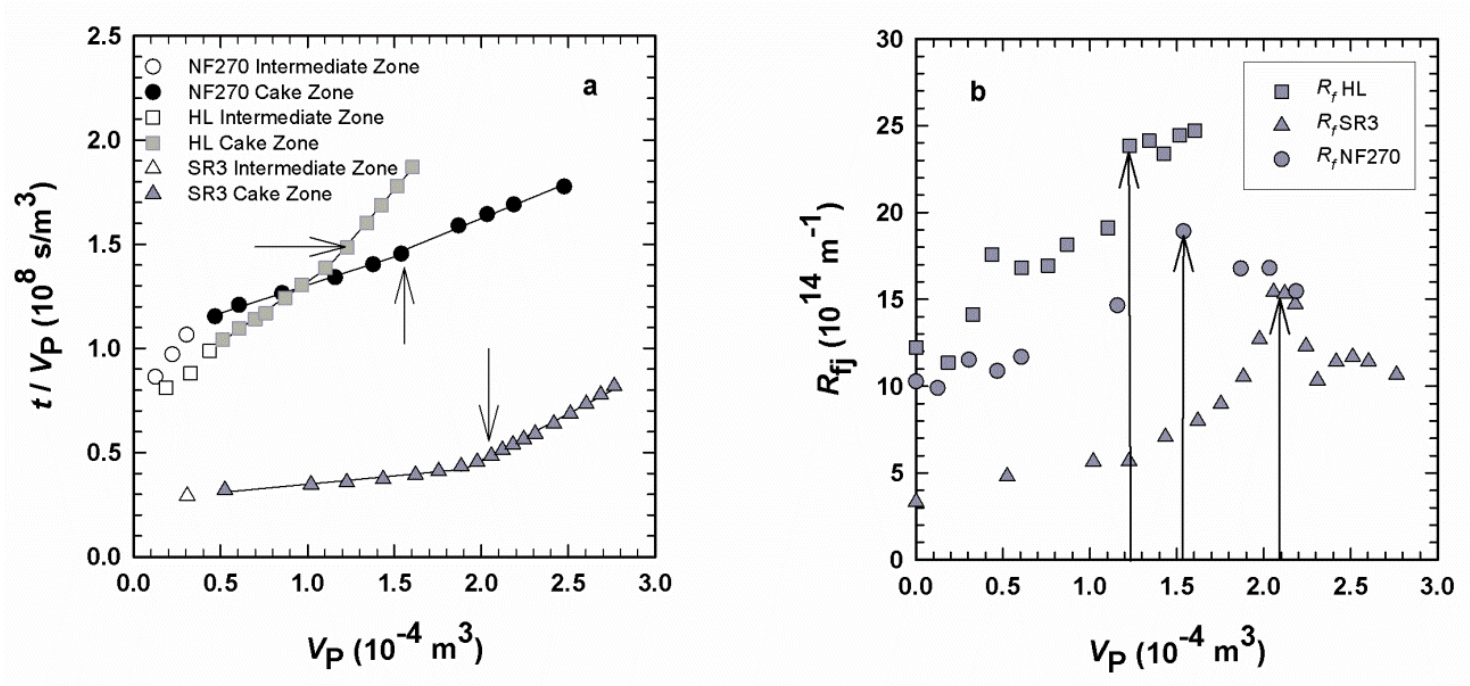

Figure 1 (a) $\left(t / V_{\mathrm{P}}\right)$ versus $V_{\mathrm{P}}$ for each membrane during red must NF. Open symbols correspond to intermediate zone; filled symbols correspond to cake formation mechanism zone; (b) Comparison of the total fouling $\left(R_{f}\right)$ resistance for the three membranes. Arrows point to the respective maxima

Apparent membrane pore size can also be used to study flux decay through the analysis of its evolution. In order to estimate pore size, a convection-difussion model was used. The model used considers only the steric partitioning in the interface, with the introduction of the applied pressure gradient term. According to it, the retention coefficient, $R$, is a function of the pore radius, $r_{p}$. From a set of data, of $J_{v}$ and $R$, the pore radius was estimated for the three membranes along the filtrations of the LMW model solution and grape must. In this way the evolution of the retention and effective pore radii was studied. Results showed that during the permeation of must, there was a continuous increase of retention while flow decreases slowly. This progressive increase of retention was so high that it seemed inappropriate to assume a single pore size. In this case, the model was applied to each measurement and the pore radius obtained as a function of the permeated volume. In Figure 2, the effective pore radii evaluated from must retention experiments are shown. It can be seen that there was a clear reduction of the effective pore size of the membrane (much slower, although a little larger, for the SR3 membrane). The mean pore radii for the synthetic solution are also shown here by horizontal lines. The evolution of retention and the effective pore size shows that for long filtration periods the three membranes show similar final effective pore size. In spite of the final convergence in equivalent pore radii, initial details do show differences between the membranes, especially between SR3 and the other two. Figure 2 shows a clear and pronounced drop of pore radii during the very first filtration moments for NF270 and HL. This happened as a consequence of the initial pore blocking mechanism. It appears clear that, for $\mathrm{HL}$ and NF270, pore blocking was the 
main factor determining the effective pore size with a final smooth additional reduction of pore size caused by the formation of the cake. The SR3 membrane was only slightly influenced by pore blocking with a final deep reduction due to the cake deposit and its compaction. Vertical solid lines arrows in Figure 2 correspond to the maximal resistances. Thus, it seems clear that maximal resistance occurs when the trend of decrease in pore size due to the cake formation starts to stabilize. This is especially apparent for the SR3 membrane.

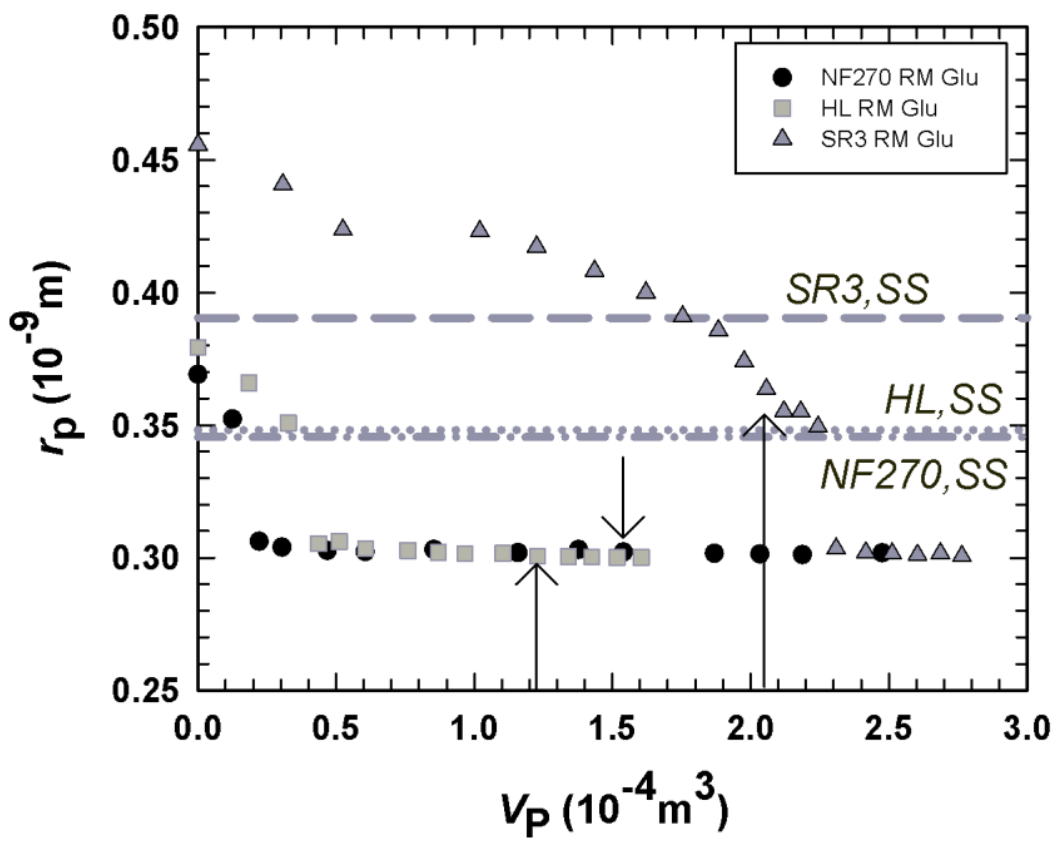

Figure 2.-Time evolution of pore radii calculated for each single data point of $\bullet$ NF270 (Glu), $\mathrm{HL}(\mathrm{Glu}), \boldsymbol{\Delta} \mathrm{SR} 3$ (Glu) of the red must NF process. As example the glucose (GLU) data are shown. Horizontal lines represent the average values obtained for the synthetic solution (SS) $\mathrm{NF}$ along the complete process. Arrows correspond to the maximum total fouling resistance for each membrane (according to Figure 1)

The analysis of the flux decay and retention of sugar in musts showed that, two of the three membranes studied, HL and SR3 are appropriate to reduce the content of sugar of red must. Specifically SR3 showed the best passage of sugar and less fouling as shown in Figure 1a. Therefore SR3 membrane was selected to continue the studies.

Membranes can be presented in several configurations such as: spiral wound, hollow fibers, tubular and plate-and-frame modules. Amongst them, spiral wound modules (SWM) are often preferred in industry because they offer a good balance between ease of operation, fouling control, permeation rate and packing density. Therefore, as a continuation of this research, the scale-up of the selected NF process was tested using the SR3 membrane in a spiral wound configuration. The analysis of the differences between red grape must NF at laboratory and at pilot plant scale using 
the same membrane were considered as the first stage of the optimization of the procedure for sugar reduction of must at a higher scale. Specifically the fouling mechanisms, sugars rejection and osmotic pressure were compared. For this purpose, the previous results obtained for the NF of grape must using the SR3 membrane in a flat sheet crossflow module were compared with those obtained for the filtration of must using the same membrane in a spiral wound module. Moreover, because in previous studies the increase of the osmotic pressure was considered to be a limiting factor of the permeate flux, the study of the increase of the applied transmembrane pressure was relevant. Therefore the effect of the variation of the applied pressure in the performance of the SWM was also analyzed in order to continue with the optimization process. The comparison of the performance of both modules allowed the analysis of the influence of feed spacers on fouling mechanism, time evolution of sugar retention and osmotic pressure during must nanofiltration. Results showed that the flow destabilization and eddy promotion caused by spacers in the SWM mitigated the rate at which the cake thickens and compacts on the membrane surface. The latter caused a less-sharp $J_{v}$ decrease with more appropriate almost constant sugars rejection and small osmotic pressure differences.

Furthermore, higher applied pressure promoted a higher membrane fouling and osmotic pressure that worsen the flux decay. In this sense, the optimization of the system wouldn't consist in a simple increase of the applied transmembrane pressure but in promoting higher shear stress (presumably with a higher effective velocity) on the membrane surface combined with higher driving force (applied pressure). Thus, $J_{v}$ would be increased and concentration polarization would be mitigated decreasing also the resistance toward mass transport (i.e. osmotic pressure and fouling).

Aiming to select the most appropriate NF technique at pilot plant scale to reduce the alcohol content of wines different NF tests were carried out for sugar control before fermentation. Therefore the performance of single- stage and two-stage nanofiltration processes were compared for white must (Spanish Verdejo) while for red must (Spanish Garnacha) a two-stage procedure was tested. Moreover, during the single stage procedure 2-minutes-stops were performed every 30 minutes. In this way, only the osmotic pressure acts as driving force creating a backflush of permeate to the retentate. This overturn of the flow promotes shear, which may affect the deposition and detachment behavior of the fouling species on the membrane surface. Figure 3 provides as an example the scheme of the techniques tested and the mixtures of must white must carried out before fermentation. 


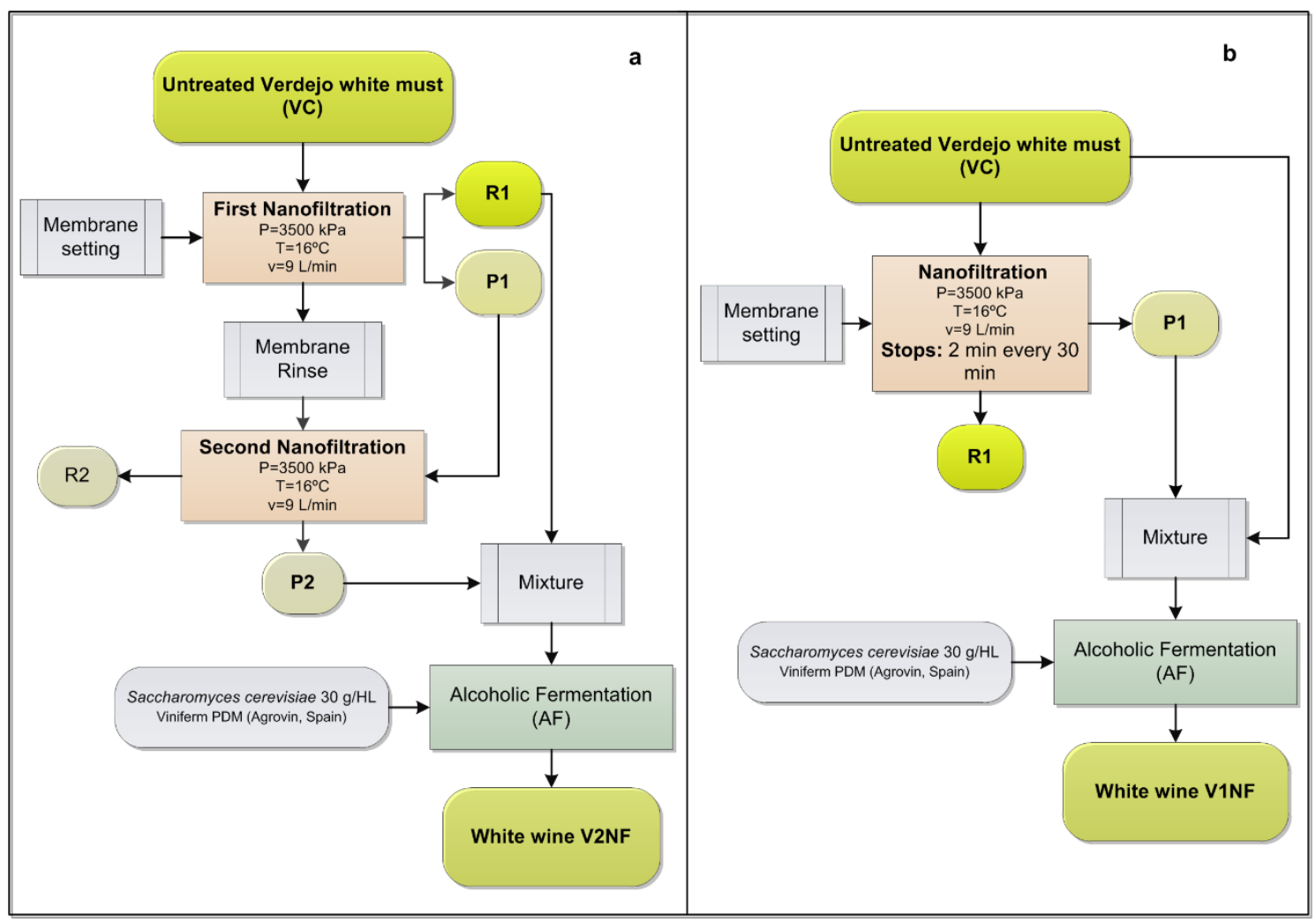

Figure 3. Scheme of the Nanofiltration procedures carried out for the Verdejo white must and ulterior fermentation. (a) two-stage and (b) single-stage nanofiltration

The analysis of the permeate flux of the different techniques showed that the use of backflush during the single-stage NF of Verdejo must was not appropriate since it caused lower permeate flow values. This means that it did not improve the productivity of the process. Apparently, the permeate backflush affects in an unexpected way the deposition of foulants and their attachment on the membrane surface, this is, on the growing cake surface. Results suggest that the re-suspension of the deposited molecules promoted by shear leads to a thinner cake or the formation of smaller aggregates. This may have higher resistance to the permeate flux and therefore be more effective in reducing the permeate flow.

After the NF processes, permeate one (P1) of the single-stage or two (P2) of the two-stage were blended with untreated juice and with first retentate (R1) respectively. Mixtures were carried out in order to preserve the specific grape features linked to the high molecular weight components present the original must or retained in $\mathrm{R} 1$ but with lower sugar content in comparison to the original must. These blends were chemically analyzed revealing the feasibility of single-and-two- stage NF processes for sugar reduction in grape must without a significant alteration of important compounds such as polyphenols, malic and tartaric acids. Moreover, results showed that the 
mixture (P2+R1) promoted a higher recovery of polyphenolic compounds (IPT) than with untreated must $(\mathrm{P} 1+\mathrm{C})$.

Three different Garnacha red wines were elaborated: A control made from the control must (GC) and two low alcohol content wines obtained from the mixture of musts (P2+R1): G2NF1 and G2NF2. Also, three different Verdejo white wines were manufactured: a control (VC), and two low alcohol content wines: one made from the mixture proceeding from the single-stage nanofiltration $(\mathrm{P} 1+\mathrm{C})$ : $\mathrm{V} 1 \mathrm{NF}$ and one produced from the mixture (P2+R1) obtained from the two-stage nanofiltration process: V2NF. The corresponding wines obtained by adequate mixing of permeated and retained or control musts showed a 1 to 2 degrees alcohol reduction. Moreover, they were submitted to a sensory evaluation which revealed that none of the wine samples was particularly preferred by the consumers, showing that there were no significant differences between the control and the filtered wines. Furthermore, this evaluation showed that NF did not affect significantly the odor and color of the resulting red wines, since the G2NF1 had the highest color and odor acceptance. Regarding white wines, they showed the highest acceptance in flavor and overall liking. But sample V1NF presented lower persistence in mouth. This feature could be related, from the sensorial point of view, to a wine with a lower alcohol degree. Besides, Verdejo is a wine variety characterized by its aroma components (volatile compounds). That is why nanofiltration could be more effective in the loss of these compounds in this variety.

All in all, it can be said that among the processes studied, the best NF technique is the two- stage process without backflush. This technique allows not only an appropriate sugar content reduction, but also the mixture $(\mathrm{P} 2+\mathrm{R} 1)$ promotes a higher recovery of polyphenolic compounds (i.e. color). Besides it minimizes volume losses since the retentate of the first stage and the permeate of the second stage are used for the appropriate blend of must .Therefore, this technique could be applied at a larger scale for the production of low alcohol content wines.

In order to minimize the resulting impairment of the aroma and flavor quality of the final wine, the primary aroma compounds could be recovered from the grape juice before NF and then added back to the filtered must before fermentation. In view of their intrinsic characteristics, namely high selectivity and possibility of operation at moderate temperatures, pervaporation (PV) is a membrane process that seems highly appropriate for the separation of dilute species in liquid solutions. Specifically, organophilic PV membranes have a high potential for recovering natural and naturalidentical aroma compounds, highly diluted in complex aqueous media. For the selection of the appropriate PV membrane the performance of two membranes was assessed. One was coated with polyether-block-amide (PEBA) and the other with 
polydimethylsiloxane (PDMS). For this purpose, PV experiments were carried out using a model aqueous solution made of six of the main aroma compounds present in grape must. These substances were two aldehydes: Hexanal and Benzaldehyde and four alcohols: isoamylalcohol, 1-hexanol, benzylalcohol and 2-phenylethanol. The concentration of each compound was in ppm levels. Results were then tested using natural grape must as feed of the experiments. The module used was a flat sheet crossflow module. During model solution experiments it was observed that both membranes have higher selectivity for aldehydes than for alcohols. But PEBA membrane was not selective to benzylalcohol since this compound could not be detected in its permeate. In general, PDMS membrane presented better permeation performance parameters. Both membranes showed a different permeation behavior during pervaporation of grape juice tests changing to a higher selectivity for alcohols. This means that probably aldehydes have stronger interactions than alcohols with the rest of the components of grape must. This study revealed the feasibility of pervaporation for natural aroma recovery in beverages to decrease aromatic depletion before their processing. Even though both membranes exhibited similar performance, PDMS showed the best permeation behavior to all compounds of interest and for both feeds.

The last study of the present work evaluates the performance of the combination of pervaporation and nanofiltration at a higher pilot plant scale, for the elaboration of a full flavored low alcohol content wine. Based on the results obtained in the previous work, the PV SWM used was a PV-SR1 (Pervatech) with a PDMS based membrane inside for aroma recovery of grape must before NF and fermentation. Moreover, in order to reduce the time required for the NF procedure, the effective membrane area was increased in the first NF-stage (two NF SWMs arranged in parallel) and the effective crossflow velocity was increased in both stages. Two processes were studied and compared in this work in order to assess the effectiveness of PV for aroma recovery of grape must. The first process consisted of the use of a two stage NF process for the reduction of the sugar content of must. The second combined the use of PV for aroma recovery of grape must followed by the two-stage NF process for sugar reduction. A scheme that summarizes the steps and operating conditions of each process and the combination of them is depicted in Figure 4. Six different wine samples were obtained from the must blends shown in Figure 4. Two control wines (C1 and C2); two nanofiltered wines (2NF1 and 2NF2) and two pervaporated -nanofiltered wines (PV+2NF1 and PV+2NF2). 


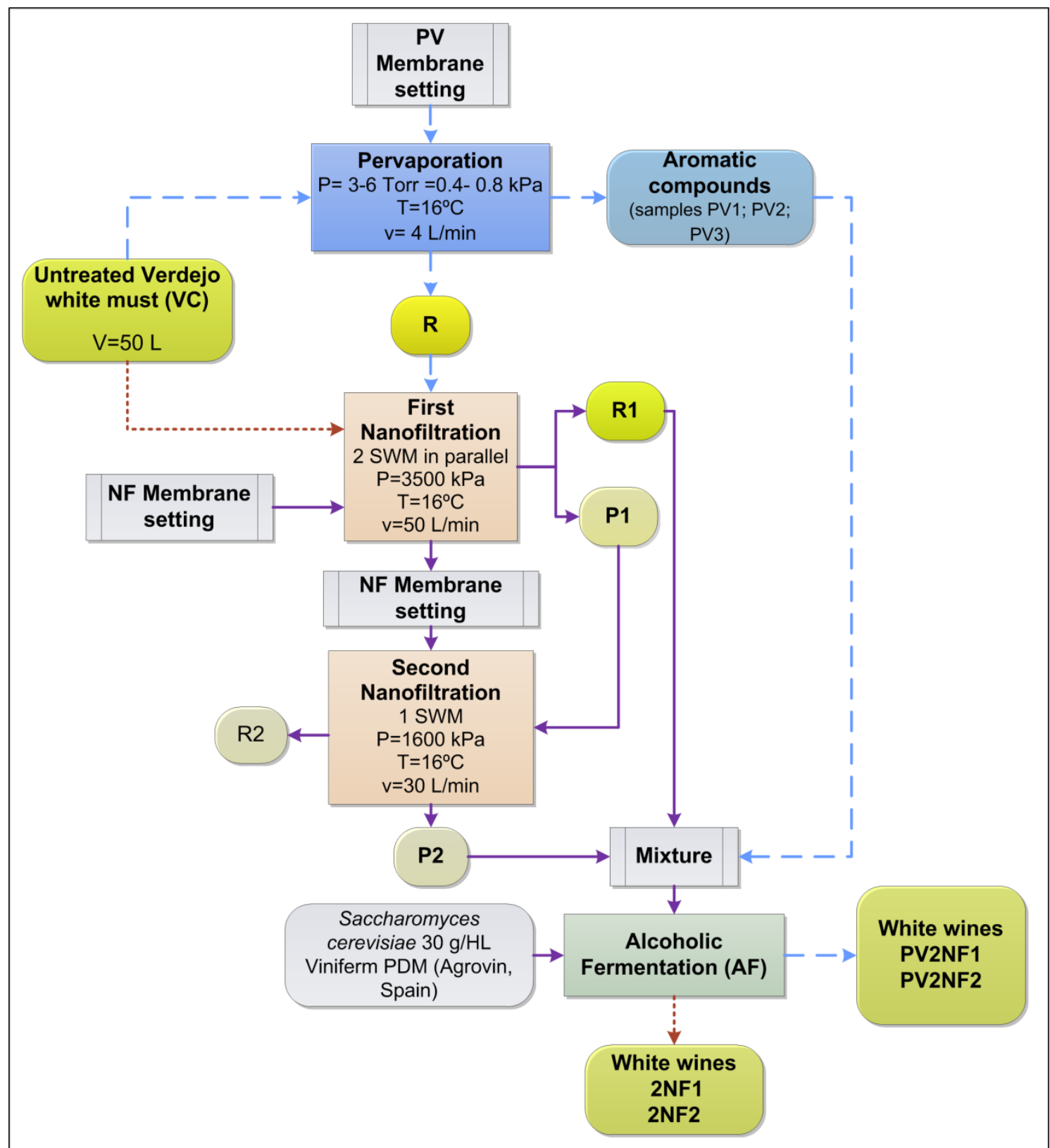

Figure 4. Experimental steps carried out during the different methods proposed. Dashed blue arrows stand for PV; red dotted arrows are only for NF and purple arrows are common for both processes.

The assessment of the permeate flux showed that in terms of the PV tests the values were remarkably lower than those obtained in the previous test using the PDMS flat sheet module. This decrease is only attributable to the difference in the configuration of the modules used. On one hand the configuration in a SWM modifies the effectivity of the vacuum in the permeate side. On the other hand, as studied before, the presence of spacers modifies the hydrodynamic conditions in the retentate side modifying concentration polarization and fouling effects. Regarding the NF tests, the new experimental set up allowed the reduction of the NF time necessary for the intended sugar control. Moreover, the analysis of the aromatic profile revealed that the 
mixture of musts ( $\mathrm{P} 1+\mathrm{R} 2+$ aromas) corresponding to the process $\mathrm{PV}+2 \mathrm{NF}$ exhibited an aroma content more similar to the original grape must with the exception of benzaldehyde and 1-hexanol.

The wines produced were sensorial analyzed and Consumers' overall liking scores showed that Sample $\mathrm{C} 1$ and $(\mathrm{PV}+2 \mathrm{NF} 1)$ were the most liked. Moreover, results exhibited that consumers found the wine samples corresponding to the PV tests more similar to the control samples. The analysis of the aroma compounds of the resulting wines showed that in comparison to the most liked control wine, wines coming from the PV experiments had a more similar aromatic profile than the ones coming only from the NF tests.

According to this study, it can be concluded that among the membrane processes assessed, the combination of PV and a 2 stage NF process presented the best results for the elaboration of a full flavored low alcohol content wine. Nevertheless mass transfer during the PV process needs to be enhanced. This can be presumably achieved by increasing the time of PV. Also a higher feed tangential flow or feed pressure should improve the aroma transfer if care was taken to avoid exceeding the maximal pressure drop through SWM recommended by the manufacturer. 



\section{RESUMEN}





\section{RESUMEN}

Como es ampliamente conocido, la mayoría de los compuestos que determinan las características sensoriales del vino son sintetizados durante la maduración de las uvas. A lo largo de este periodo, la concentración de azúcares, aminoácidos, compuestos fenólicos y sodio crece, mientras el contenido de ácidos orgánicos, principalmente el ácido málico, decrece. Estos cambios no ocurren necesariamente al mismo tiempo. Por lo tanto, para establecer la fecha de vendimia, los productores deben considerar la madurez tecnológica (es decir contenido de azúcares y acidez) y también la madurez fenólica (especialmente antocianos y taninos) y aromática de los frutos.

A lo largo de los últimos años, debido al cambio climático, varias zonas productoras de vino han proporcionado evidencia de modificaciones en el desarrollo de las viñas y patrones de maduración de las bayas. Dentro de los efectos más importantes relacionados con el cambio climático se ha observado un mayor contenido de azúcares, menor acidez y la modificación de aromas varietales. La fermentación de estos mostos conduce a contenidos alcohólicos mayores a los deseados, puesto que estos vinos resultan demasiado ardientes en boca, lo cual enmascara los aromas y sabores frutales característicos. Una vendimia y fermentación anticipadas afectaría la calidad del producto puesto que se obtendrían vinos más ácidos y con menor color ya que el fruto no habría alcanzado su madurez fenólica. Las prácticas enológicas apropiadas establecen que la calidad de los vinos depende esencialmente de la madurez fenólica de los frutos. Por lo tanto, para elaborar un vino de calidad la vendimia debe ser realizada en la madurez adecuada de los frutos y luego reducir el contenido alcohólico final del producto mediante técnicas novedosas y adecuadas.

Los productores han aplicado estos métodos principalmente a dos fuentes: vino y mosto de uva. El método de desalcoholización más utilizado en la industria alimentaria es la columna de cono giratorio mediante la cual se logra la separación de los compuestos volátiles de los líquidos. Este proceso requiere varias etapas para recuperar primero los aromas del vino, luego el alcohol y finalmente devolver los aromas al vino desalcoholizado. Puesto que ésta es una técnica cara y que requiere mucho tiempo, se han utilizado otros métodos de desalcoholización. Ejemplos de éstos son las columnas de destilación, evaporadores o concentradores por congelación. Los procesos térmicos de desalcoholización pueden producir vinos de baja graduación alcohólica, sin embargo, la mayoría de los compuestos volátiles son eliminados o deteriorados durante la recuperación del alcohol. La ósmosis inversa (OI) también se utiliza para la desalcoholización de vinos. El problema es que las 
membranas de OI son permeables tanto al alcohol como al agua y por lo tanto tras la filtración es necesaria la adición de agua al vino desalcoholizado. En algunos países esto genera problemas legales puesto que la adición de agua está prohibida por ley. Es conocido también que procesos de membrana tales como la diálisis, pervaporación y destilación por vacío con membranas también han sido utilizados para la producción de bebidas de baja graduación alcohólica.

Un control adecuado de los azúcares del mosto también se considera útil para la obtención de vinos de bajo contenido alcohólico. Ejemplos de éstos es el uso de enzimas o levaduras que utilizan los azúcares para el crecimiento celular. Sin embargo, durante estos procesos, se generan elevadas cantidades de compuestos microbiológicos secundarios como ácido glucónico o diversos ésteres. Éstos alteran la calidad sensorial del vino final.

También se han utilizado procesos de membrana para la reducción del contenido de azúcares en bebidas de fruta. Si se tiene en cuenta el peso molecular de los azúcares del mosto, la nanofiltración (NF) debe ser el proceso de membrana adecuado para controlarlos. Varios estudios han revelado la habilidad de la NF para el control de azúcares y la reducción del grado alcohólico del vino resultante. Sin embargo, se detectó una leve pérdida de color y de compuestos aromáticos además de un leve desajuste en la concentración de sustancias importantes como potasio y ácidos málico y tartárico. Conjuntamente, estos experimentos mostraron la existencia de problemas comunes en los procesos de separación por membrana. Entre éstos, los más importantes son los causados por el ensuciamiento de membrana y los relacionados con la disminución de flujo de permeado.

Por las razones mencionadas, el objetivo principal de la presente tesis doctoral es la optimización del proceso de nanofiltración para el control de azúcares de mosto de uva con el objetivo de producir vinos de contenido alcohólico reducido que, a su vez, conserven sus características sensoriales. Para tal finalidad, se debieron evaluar y estudiar distintos aspectos.

Primeramente, se realizó el análisis de la reducción del flujo de permeado $\left(J_{v}\right)$ debido al ensuciamiento, las resistencias $\left(R_{j}\right)$ y la presión osmótica generadas por los distintos compuestos característicos del mosto. En tal sentido, se desarrolló un método para el estudio de la influencia individual de los principales compuestos de alto y bajo peso molecular (LMW y HMW respectivamente) del mosto durante el proceso de NF. Para ello, se nanofiltró una disolución sintética que contenía los LMW característicos del mosto de uva, principalmente: glucosa, fructosa, ácidos málico y tartárico, potasio, sodio, calcio y magnesio. Los resultados fueron comparados con aquellos generados de la filtración (bajo las mismas condiciones de operación) de mosto tinto de uva 
comercial, el cual además de contener los solutos mencionados contiene HMW como polifenoles, polisacáridos y proteínas. Los experimentos se llevaron a cabo a escala laboratorio utilizado la membrana plana NF270 de Dow Filmtech en un módulo de flujo tangencial. La rápida formación y crecimiento de la capa de gel sobre la superficie de la membrana durante la NF de mosto, provocó condiciones extremas de análisis. Estas fueron un bajo incremento de la concentración de azúcares en el retenido y una rápida disminución de $J_{v}$, causando un pequeño volumen de permeado. A pesar de esto, el método analítico propuesto permitió el estudio de las resistencias y mecanismos de ensuciamientos generados individualmente por los LMW y HMW. Los resultados probaron que los HMW tienen mayor influencia sobre la disminución de $J_{v}$, puesto que son los principales responsables del fenómeno de ensuciamiento por formación de torta sobre la superficie de la membrana (cake filtration fouling mechanism). Mientras tanto, los LMW contribuyen a la caída de $J_{v}$ principalmente a través del incremento de la presión osmótica durante el proceso. Respecto a las resistencias generadas individualmente por los $L M W$ y $H M W\left(R_{f L M W}\right.$ y $\left.R_{f H M W}\right)$ se observaron dos evoluciones diferentes. $R_{\mathrm{fLMW}}$ se mantuvo prácticamente constante en comparación a $\mathrm{R}_{\mathrm{fHMW}}$ la cual aumentó progresivamente hasta alcanzar un máximo a partir del cual se observó una leve disminución. La caída de $R_{\mathrm{fHMW}}$ al final de la filtración de mosto sugirió que la torta formada sobre la superficie de la membrana puede ser compresible, lo cual provoca un aumento de la presión osmótica. Ésto reduce la caída de presión efectiva a través de la torta formada y por lo tanto su resistencia a $J_{v}$. Además se observó que la formación de la capa de gel sobre la superficie de la membrana provocó el cambio de la retención de los azúcares, pero la compresión de esta capa aumento aún más la retención.

De acuerdo a estos resultados, el siguiente aspecto que debía ser abordado era la selección de la membrana de NF más apropiada para el objetivo planteado. Para ello, ésta debe poseer una retención a los azúcares apropiada (tamaño de poro): aproximadamente 50\% y baja afinidad hacia los HMW (polímero de fabricación) para evitar la acumulación de estas sustancias sobre su superficie y así conservar sus propiedades de retención sustancialmente inalteradas. En tal sentido, el método anteriormente propuesto se utilizó para el estudio sistemático y comparación de diferentes membranas de NF. Los parámetros evaluados fueron: ensuciamiento, resistencias al $J_{v}$ y gradiente de presión osmótica a través del sistema de membrana generados individualmente por los LMW y HMW a lo largo de la NF de mosto tinto de uva. En este trabajo se estudió el funcionamiento de tres membranas de NF planas: NF270, de Dow Filmtech; HL, de GE: Water \& Proccess technologies, y KMS SR3 de Koch Membrane Systems. La Figura 1a muestra que para las tres membranas el 
mecanismo de ensuciamiento, en presencia de los HMW estuvo compuesto de tres etapas consecutivas: bloqueo de poros, seguido de deposición de la torta y un crecimiento y compresión de la misma hasta alcanzar la compactación (flechas en la Figura 1a). A su vez, se observó un aumento en la retención de azúcares durante el crecimiento de la torta, el cual alcanzó un máximo cuando ésta estaba completamente formada. Para las tres membranas se observó que durante este proceso, la presión osmótica del sistema aumentó y por lo tanto la presión efectiva disminuyó. La $R_{f H M W}$ incrementó progresivamente hasta alcanzar un máximo a partir del cual se observó un leve decrecimiento. En la Figura 1b se muestra la comparación de las resistencias debidas al ensuciamiento $\left(R_{f}\right)$ para las tres membranas estudiadas. Relacionando el mecanismo de ensuciamiento por formación de torta con las resistencias, se apreció que en los tres casos el máximo de $R_{f}$ coincide con el comienzo del tercer mecanismo de ensuciamiento, es decir cuando la torta comienza a compactarse.
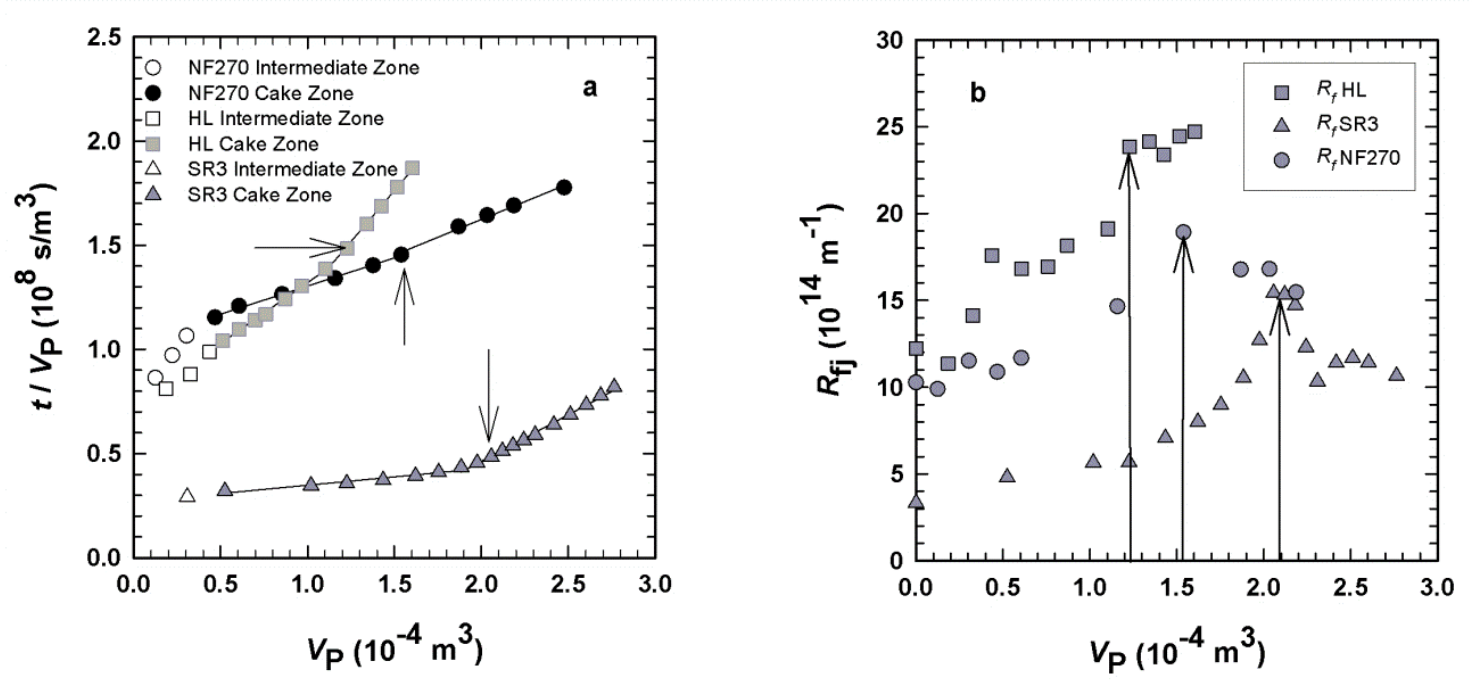

Figura 1 (a) $\left(t / V_{\mathrm{P}}\right)$ versus $V_{\mathrm{P}}$ para cada membrana durante la NF de mosto tinto. Los círculos blancos correponden al mecanismo intermedio, los símbolos coloreados representan en mecanismo de formación de torta. (b) Comparación de la resistencia total debida al ensuciamiento $R_{f}$ para las tres membranas. Las flechas muestran el máximo en $R_{f}$ correspondiente

Mediante el análisis de la evolución del tamaño de poro aparente también puede estudiarse la caída de flujo de permeado. El modelo utilizado considera únicamente la partición estérica en la interface con la introducción del término de gradiente de presión aplicada. De acuerdo a él, el coeficiente de retención, $R$, es una función del radio de poro $r_{p}$. A partir de los valores de $J_{v}$ y $R$ obtenidos durante la filtración de LMW y de mosto tinto se estimó el radio de poro para las tres membranas. De esta forma, se estudiaron la evolución del radio de poro efectivo y la retención. Los resultados mostraron que durante la permeación de mosto ocurría un aumento progresivo en la retención mientras que el flujo disminuía lentamente. Este incremento 
progresivo de la retención fue tan pronunciado que pareció inapropiado asumir un tamaño de poro único. En nuestro caso, el modelo fue aplicado para cada par de valores y así se obtuvo el radio de poro en función del volumen permeado. En la Figura 2 se muestra el radio de poro efectivo evaluado de los experimentos de filtración de mosto. Se puede apreciar una clara reducción en el tamaño de poro de la membrana el cual fue mucho más lento pero finalmente mayor para el caso de la membrana SR3. El radio de poro medio calculado para la disolución sintética se muestra en la figura mediante líneas horizontales.

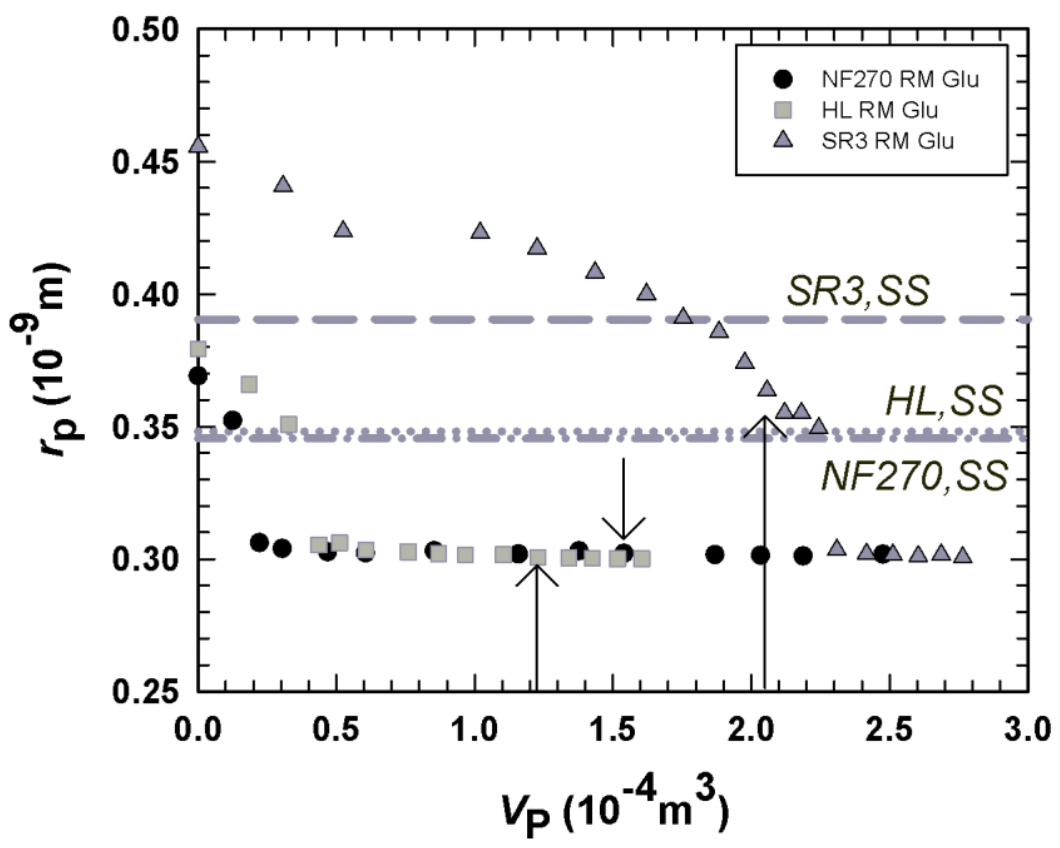

Figura 2 Evolución del tamaño de poro calculado para cada par de valores de - NF270 (Glu), - HL (Glu), $\Delta$ SR3 (Glu) en la filtración de mosto tinto. Como exemplo se muestran los valores generados para la glucosa (GLU). Las líneas horizontales representan los valores medios obtenidos durante la filtración de la disolución sintética (SS). Las flechas corresponden al máximo de la resistencia debida al ensuciamiento de cada membrana (de acuerdo a la Figura 1)

La evolución de la retención y el tamaño efectivo de poro muestra que para periodos de filtración largos las tres membranas alcanzan un valor mínimo similar. A pesar de la convergencia final, los valores iniciales sí mostraron diferencias entre las tres membranas, especialmente entre la SR3 y las otras dos. La Figura 2 muestra una clara y pronunciada reducción del tamaño de poro durante los primeros instantes de filtración para las membranas NF270 y HL. Este suceso ocurrió como consecuencia del mecanismo inicial de bloqueo de poro. Claramente se aprecia que este mecanismo es el factor determinante del tamaño de poro de las membranas NF270 y HL en tanto que la formación de la torta ocasiona una pequeña disminución adicional del poro 
efectivo. En cambio la membrana SR3 fue mínimamente influenciada por el bloqueo de poros y se observó una pronunciada disminución final debida a la formación y compactación de la torta. Las flechas en la Figura 2 corresponden a los máximos observados en $R_{f}$. Por lo tanto, parece claro que el máximo en la resistencia ocurre cuando el tamaño de poro tiende a decrecer debido a la formación de la torta. Este hecho es especialmente notorio para la membrana SR3.

El análisis de la disminución de flujo de permeado y la retención de azúcares demostró que dos de las tres membranas evaluadas, HL y SR3, son apropiadas para la reducción de azúcares en el mosto. Particularmente la SR3 mostró el mejor pasaje de azúcares y menor ensuciamiento como puede apreciarse en la Figura 1a. Por lo tanto la membrana SR3 fue seleccionada para la continuación de los estudios de la presente tesis.

Como es sabido, las membranas pueden presentarse en diferentes configuraciones, tales como módulos en espiral, de fibras huecas, tubulares o de placas y marcos. Entre todos ellos, los módulos en espiral (SWM) son mayormente preferidos en la industria puesto que ofrecen una mejor relación entre facilidad de operación, ensuciamiento, flujo de permeado y densidad de empaquetamiento. Por lo tanto, como continuación de este trabajo se estudió el escalado del proceso de NF utilizando la membrana SR3 en una configuración en espiral. Para la optimización del proceso a mayor escala, se consideró apropiado primeramente analizar las diferencias principales entre las filtraciones de mosto a escala laboratorio y escala piloto utilizando la misma membrana. Concretamente se compararon los mecanismos de ensuciamiento, retención de azúcares y presión osmótica. Para ello, los resultados obtenidos previamente, utilizando la membrana plana SR3 en el módulo de flujo tangencial, se compararon con aquellos obtenidos de la filtración de mosto de uva tinto utilizando la misma membrana en un SWM. Además, puesto que en el estudio previo se concluyó que la presión osmótica es un factor limitante en el flujo de permeado, se consideró apropiado el estudio de la influencia del incremento en la presión aplicada en el funcionamiento del SWM. La comparación del rendimiento de ambos módulos permitió el análisis de la influencia de los espaciadores en el mecanismo de ensuciamiento, evolución de la retención de azúcares y presión osmótica durante la filtración de mosto. Los resultados probaron que la desestabilización de flujo y la promoción de vórtices generada por los espaciadores en el SWM mitigaron la velocidad de crecimiento de la torta sobre la superficie de la membrana. Ésto se tradujo en una disminución menos pronunciada de $J_{v}$, una retención de azúcares constante y una diferencia de presión osmótica pequeña. A su vez, se observó que un incremento en la presión aplicada promueve un mayor ensuciamiento de la membrana 
y presión osmótica lo cual provocó una mayor disminución de $J_{v}$. En tal sentido, la optimización del proceso no consistiría en un simple incremento de la presión aplicada. Lo que debe hacerse es promover un mayor esfuerzo de corte sobre la superficie de la membrana (presumiblemente mediante una mayor velocidad efectiva) combinada con una mayor fuerza motriz (presión aplicada). De esta forma se incrementaría $J_{v}$ y los efectos de la polarización por concentración se mitigarían reduciendo también las resistencias al transporte de masa (presión osmótica y ensuciamiento).

Con el objetivo de seleccionar a escala piloto la técnica de NF más apropiada para la reducción del contenido de alcohol en vinos, se realizaron distintas pruebas de NF para la reducción de azúcares antes de la fermentación. Para ello se comparó el rendimiento de un proceso de etapa simple de NF y uno de doble etapa de NF utilizando mosto de uva blanco (Verdejo). A su vez se estudió el rendimiento en mosto tinto (Garnacha) de un proceso de doble etapa de NF. Además durante el proceso de etapa simple se realizaron paradas de 2 minutos cada 30 minutos. De esta forma sólo actúa como fuerza motriz la presión osmótica creando un flujo inverso desde el permeado hacia el retenido. Esta inversión en el sentido del flujo provoca esfuerzos de corte los cuales pueden afectar a la deposición y adhesión de los compuestos acumulados sobre la superficie de la membrana. La Figura 3 proporciona un esquema que ejemplifica las técnicas estudiadas y las mezclas de mosto blanco realizadas antes de la fermentación.

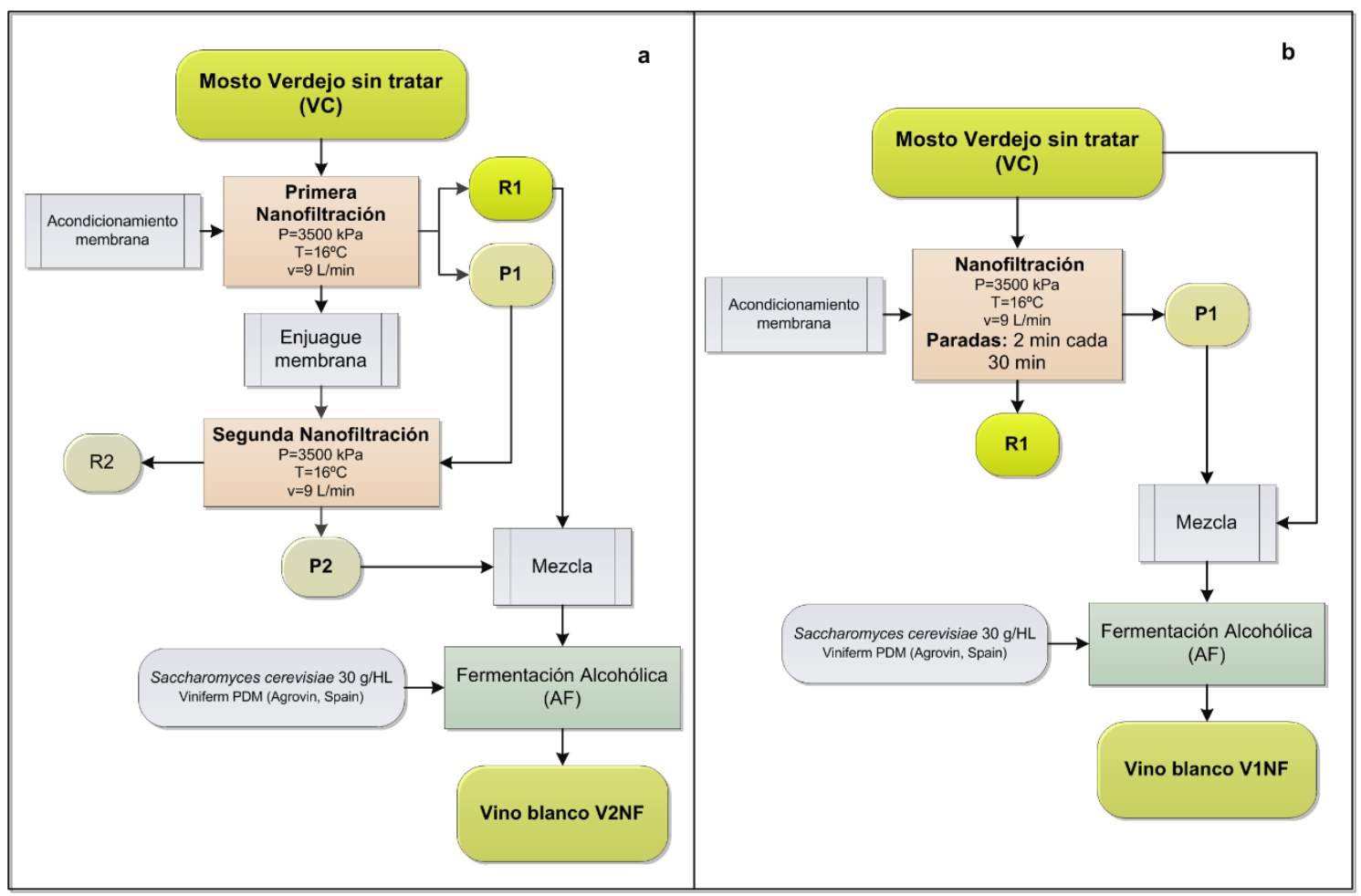

Figure 3 Esquema de los procesos de NF llevados a cabo para el mosto blanco Verdejo y posterior fermentación. (a) NF de doble etapa, (b) NF de etapa simple 
El análisis del flujo de permeado de las diferentes técnicas propuestas demostró que la aplicación del retro flujo durante la NF de etapa simple no fue adecuado, puesto que produjo una mayor caída de $J_{v}$. Esto significa que no mejoró la productividad del proceso. Aparentemente el retro flujo de permeado afecta inesperadamente el depósito y adhesión de las partículas sobre la superficie de membrana. Los resultados sugieren que la re-suspensión de las moléculas depositadas ocasionada por los esfuerzos de corte se traducen en la formación de una torta más delgada compuesta de agregados más pequeños. Ésta puede tener mayor resistencia al flujo de permeado y por lo tanto ser más efectiva en la reducción de $J_{v}$.

Tras los procesos de NF, el primer permeado (P1) del proceso de etapa simple o el segundo (P2) del proceso de doble etapa se mezclaron respectivamente con mosto original o con el primer retenido (R1). Así estas mezclas preservan características de las uvas relacionadas con los HMW presentes en el mosto o retenidas en $\mathrm{R} 1$, pero con un contenido de azúcares menor al original. Las mezclas fueron analizadas químicamente revelando la habilidad de ambos procesos para la reducción de azúcares sin alterar significativamente la concentración de otros compuestos tales como polifenoles y ácidos málico y tartárico. A si mismo, los resultados mostraron que la mezcla $(\mathrm{P} 2+\mathrm{R} 1)$ promueve una mayor recuperación de compuestos polifenólicos que la mezcla $(\mathrm{P} 1+\mathrm{C})$.

Se elaboraron tres vinos tintos de la variedad Garnacha: Un testigo (GC) y dos de baja graduación alcohólica a partir de la mezcla (P2+R1): G2NF1 y G2NF2. A su vez se elaboraron tres vinos blancos de la variedad Verdejo: un testigo (VC) y dos vinos de bajo contenido alcohólico, uno proveniente de la mezcla $(P 1+C)$ : V1NF y otro producido a partir de la mezcla (P2+R1): V2NF. Los vinos obtenidos mostraron una reducción del contenido alcohólico entre 1 y 2 grados. Además éstos fueron evaluados sensorialmente por un panel de consumidores. Los resultados afirmaron que ninguno de los vinos fue particularmente preferido por los consumidores. Esto significó que no existieron diferencias significativas entre los vinos testigo y los nanofiltrados. A su vez, este análisis reveló que la NF no afectó el olor y color de los vinos obtenidos. Particularmente los vinos blancos presentaron los valores más altos en sabor y aceptabilidad global. Pero la muestra V1NF exhibió los valores de persistencia en boca más bajos. Este atributo puede estar relacionado sensorialmente con una baja graduación alcohólica. Además la variedad Verdejo se caracteriza por ser muy aromática, es decir por poseer una mayor cantidad de compuestos volátiles. Es por ello que la NF puede ser más efectiva en la pérdida de estos compuestos en esta variedad de vino. 
En general, puede decirse que entre los procesos estudiados, la mejor técnica de NF fue el proceso de doble etapa sin retro flujo. Este método permitió no solamente una correcta reducción de azúcares sino que a su vez la mezcla (P2+R1) promueve una mayor recuperación de compuestos polifenólicos (color) y una menor pérdida de volumen útil.

Con la finalidad de minimizar el deterioro de la calidad aromática y de sabor detectados, los compuestos aromáticos primarios podrían ser recuperados de la alimentación antes de la NF y ser agregados nuevamente al mosto filtrado antes de la fermentación. Debido a sus características intrínsecas, principalmente alta selectividad y posibilidad de trabajo a temperaturas moderadas, la pervaporación (PV) parece ser el proceso de membrana más apropiado para la recuperación de compuestos altamente diluidos en matrices acuosas complejas. Para la selección de la membrana de PV más apropiada se evaluó el funcionamiento de dos membranas. Una de ellas recubierta del polímero polyeter-block-amida (PEBA) y la segunda de polydimetilsiloxano (PDMS). Para tal fin se llevaron a cabo experimentos de PV utilizando una disolución modelo acuosa compuesta de seis de los principales compuestos aromáticos característicos del mosto de uva. Estas sustancias fueron, dos aldehídos: hexanal y benzaldehído y cuatro alcoholes: alcohol isoamílico, 1- hexanol, alcohol bencílico y 2- feniletanol. La concentración de cada compuesto fue del orden de los ppm. Los resultados fueron luego comparados con aquellos generados de la PV de mosto de uva natural. Los experimentos se llevaron a cabo a escala laboratorio en un módulo de membrana de flujo tangencial. Durante los experimentos utilizando la disolución modelo, se observó que ambas membranas tienen una mayor selectividad hacia los aldehídos que hacia los alcoholes. Sin embargo, la membrana de PEBA no fue selectiva hacia el alcohol bencílico puesto que no se detectó su presencia en el permeado. En general la membrana de PDMS demostró mejores parámetros de funcionamiento. Ambas membranas exhibieron un comportamiento de permeado distinto durante la PV de mosto de uva. En este caso, ésta fue mayor hacia los alcoholes. Ello significa que probablemente los aldehídos poseen mayor interacción con los compuestos de la matriz del mosto que los alcoholes. Por lo tanto, este estudio reveló la habilidad de la PV para la recuperación de aromas naturales antes del procesado de bebidas con el objetivo de disminuir el deterioro aromático del producto. Finalmente, a pesar de que ambas membranas mostraron un rendimiento similar, la de PDMS presentó una mejor permeación hacia todos los compuestos de interés en ambas alimentaciones.

El último estudio realizado en este trabajo, evalúa el funcionamiento de la combinación de los procesos de pervaporación y nanofiltración a escala piloto para la 
elaboración de un vino de bajo contenido alcohólico que conserve sus propiedades organolépticas completas. Basados en los resultados obtenidos en el estudio previo, el SWM de pervaporación utilizado para la recuperación de aromas antes de la NF, fue el PV-SR1 (Pervatech) con una membrana recubierta de PDMS en su interior. Además, con el objetivo de reducir el tiempo necesario para el proceso de NF, se incrementó durante la primera etapa el área efectiva de membrana utilizando dos módulos en paralelo y aumentando la velocidad efectiva del proceso. En esta investigación se estudiaron y compararon dos técnicas con el objetivo de evaluar la efectividad de la aplicación de la PV. La primera experiencia consistió en el uso de un proceso de NF de doble etapa para la reducción de azúcares. El segundo proceso estudiado combinó el uso de PV para la recuperación de compuestos aromáticos seguido de un proceso de NF de doble etapa para la reducción de azúcares. La Figura 4 proporciona un esquema que resume las etapas y condiciones de operación de cada proceso. Tras las filtraciones se elaboraron seis muestras de vino. Dos vinos testigos ( $\mathrm{C} 1$ y $\mathrm{C} 2)$, dos nanofiltrados (2NF1 y 2NF2) y dos pervaporados y nanofiltrados (PV+2NF1 y $\mathrm{PV}+2 \mathrm{NF} 2)$.

El análisis del flujo de permeado de las pruebas de PV mostró que los valores obtenidos fueron considerablemente menores que los correspondientes a las pruebas realizadas a escala laboratorio. Esta disminución es únicamente atribuible a la diferencia en la configuración de los distintos módulos utilizados. Por una parte,, la configuración en un SWM modifica la efectividad del vacío en el lado del permeado. Por otro, como se estudió anteriormente, la presencia de los espaciadores modifica las condiciones hidrodinámicas en el lado del retenido, variando los efectos del ensuciamiento y de concentración por polarización. Con respecto a las pruebas de NF, el nuevo dispositivo experimental permitió disminuir del tiempo necesario para la reducción de azúcares. Además, el análisis del perfil aromático reveló que la mezcla de mostos ( $\mathrm{P} 1+\mathrm{R} 2+$ aromas) correspondiente al proceso de $\mathrm{PV}+2 \mathrm{NF}$ poseía un contenido aromático más parecido al mosto original a excepción del benzaldehído y el 1-hexanol.

Los vinos elaborados fueron analizados sensorialmente por un panel de consumidores. Los valores de aceptabilidad global exhibieron que las muestras $\mathrm{C} 1 \mathrm{y}$ $(\mathrm{PV}+2 \mathrm{NF} 1)$ fueron las más preferidas. Además, los resultados demostraron que los consumidores detectaron las muestras correspondientes a las pruebas de PV más parecidas a las muestras testigo. El análisis aromático de los vinos obtenidos demostró que, en comparación con $\mathrm{C} 1$, los vinos provenientes de las pruebas de PV poseían un perfil aromático más parecido que los respectivos al proceso de NF. 


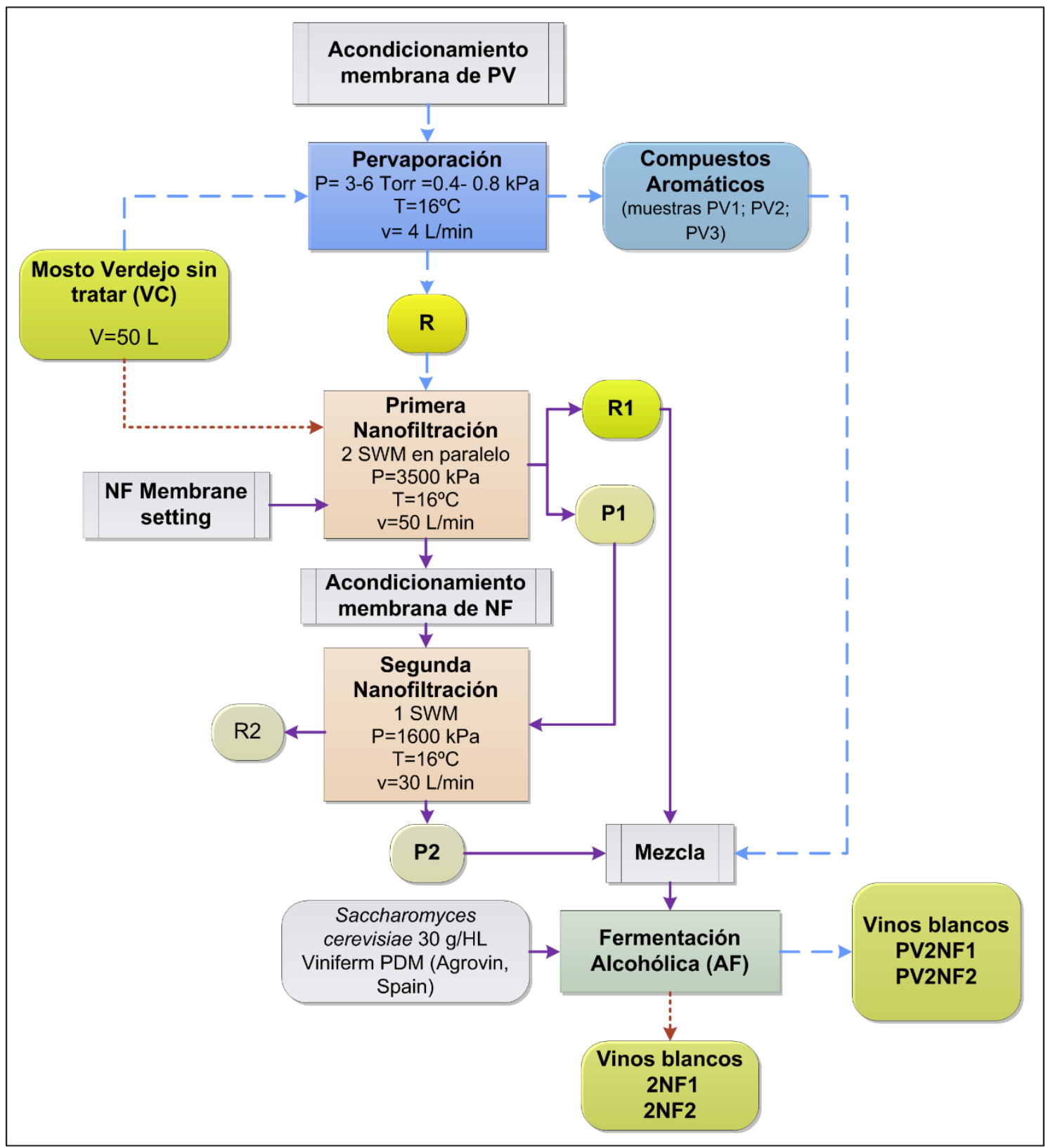

Figura 4 Etapas llevadas a cabo durante los procesos de membrana propuestos. Las líneas de trazos azules corresponden a la PV, las líneas de puntos rojas corresponden al proceso de NF y las líneas moradas representan a las etapas comunes en ambos procesos

De acuerdo a este estudio se puede concluir que entre los procesos de membrana evaluados, la combinación de PV y un proceso de doble etapa de NF presentaron los mejores resultados para la elaboración de vinos de baja graduación alcohólica y elevada calidad organoléptica. Sin embargo, hay que incrementar la transferencia de masa durante el proceso de PV. Esto se puede lograr presumiblemente elevando el tiempo de PV. A su vez, una mayor velocidad de flujo tangencial o presión aplicada incrementarían la transferencia de aromas. Es importante mencionar que esto debe realizarse teniendo en consideración las 
condiciones límite de gradiente de presión dentro del SWM recomendadas por el proveedor. 
SECTION I. INTRODUCTION AND GENERAL METHODOLOGY 



\section{Chapter 1}

From grapes to wine. Analysis of current

situation 



\section{Chapter 1. From Grapes to wine. Analysis of current situation}

\subsection{Problematic and Motivation: Influence of climate change on grape maturation and wine quality}

Ripening of grapes is considered to be the physiological period of the plant that starts with veraison and ends with berry maturity. During it, the majority of the compounds that determine the sensory characteristics of wines are synthetized [1]. Along this period, the concentration of sugars, aminoacids, phenolic compounds and potassium increase, while the content in organic acids, particularly malic acid, decreases. These changes do not necessarily occur simultaneously and it is therefore necessary to control all of them to determine the optimal date of harvest. Classical parameters based on technological maturity, i.e. sugar content, total acidity and $\mathrm{pH}$ are used to identify the harvest date. However analysis of phenolic and volatile compounds is important to monitor the varietal characteristics of grapes and to obtain the maximum wine quality. The phenolic composition of the grape at maturity, especially regarding anthocyanins and tannins, has significant influence on the quality of the resulting wine. These compounds play a crucial role since they are related to color, aroma, bitterness and mouthfeel. Therefore, winemakers need to consider the technological maturity (i.e. sugar content and acidity), and also the phenolic and aroma maturity of grapes in order to set the harvest date [1-4].

Due to climate change, last years have been warmer and dryer in some areas. Over this period, observations from various world winemaking regions have provided evidence of modified vine development and fruit maturation patterns. Among the most important climate change-related effects there is higher sugar content, lower acidities and modification of varietal aroma compounds.

Regarding the sugar content, high temperatures accelerate grape maturation, but temperature effects on final sugar accumulation are relatively small. Although higher temperatures $\left(30^{\circ} \mathrm{C}\right)$ may lead to higher suspended solid concentrations. This higher Brix levels (higher than 24-25 Brix) are likely not due to photosynthesis and sugar transport from leaves and wood, but to concentration by evaporative loss. A more considerable temperature effect is known for total acidity since higher $\mathrm{pH}$ values in grapes have been measured. While the main grape acid, tartaric acid, is relatively stable with regards to temperature effects, malic acid levels decrease with higher temperatures. It has also been observed that higher temperatures lead to increased potassium levels. Besides sugars, acids and potassium, higher temperatures also modify the accumulation and formation of polyphenols which may be less important 
quantitatively but highly relevant for wine color and aroma quality. Temperatures of 30 ${ }^{\circ} \mathrm{C}$ and higher lead to lower anthocyanin synthesis, which may be completely and irreversibly inhibited at very elevated temperatures and hence reduce grape color [2] .

All in all, it can be said that during last years higher temperatures have promoted a gap between the technological and polyphenolic maturities in grapes. Therefore, if grapes are picked when the phenolic and aromatic maturity is reached, they would have a high potential alcohol content, up to $17 \%$ with low acidity [5].

The International Organization of Vine and Wine (OIV), defines wine as the beverage resulting exclusively from the partial or complete alcoholic fermentation of fresh grapes, or grape must, having an ethanol content higher than $8.5 \%$ [6]. But in some countries, as USA, wine producers have to struggle with a supplementary tax added to beverages with alcohol content over $14.5 \%$. Moreover, this over maturity leads to problems in wine making as some difficulties appear in alcoholic fermentation and in microbiological stabilization. It also causes a gustatory disequilibrium since the strengthening of warm sensation in mouth could mask the fruity aromas and taste of wine. Meanwhile, consumers show an increasing interest and demand in reducedalcohol, low-alcohol (between 9 and 13\%) and dealcoholized wines. Some of the reasons for this tendency are the social consciousness for the moderate consumption of alcohol, the regulations of these products [7, 8] and the demand of low calorie products [9]. Premature grape harvest and winemaking should affect the final wine quality, because the acidic and phenolic maturity should not be fully achieved [10] leading to more acid and less colored wines. A commendable oenological practice establishes that the quality of wines depends essentially on the maturity of phenolic components contained in the grape berries. At the same time, there is a growing demand, by consumers, of more powerful and full flavored wines that are achieved with greater maturity of the grapes, both skin and seeds. This means that producers struggle to achieve the same levels of phenolic ripeness and tannic characteristics without an increase in alcohol content. Therefore, in order to produce a full flavored wine, the harvest should be carried out in the optimum ripeness of the fruits and then innovative techniques to reduce the final alcohol content should be applied.

\subsection{Alcohol control techniques used in the grape and wine industry}

Wine producers have used many dealcoholisation processes or methods to produce low alcohol-content wine. The most used method in the industry is the spinning cone column (SCC). SCC is used in the food industry for the separation of volatile components from liquids and slurries. This procedure requires several steps to 
remove first the wine aromas and afterwards alcohol and finally the aromas are returned to the dealcoholized wine [11, 12]. Because it is a time consuming and expensive process, other dealcoholization techniques have been used too. Some examples are thermal processes such as distillation columns, evaporators, or freeze concentration [9]. Heat-based processes can produce wines with very low alcohol content $(<0.5$ vol. $\%)$, however most of the volatile aroma compounds are also lost during the ethanol removal [13].

An adequate control of sugars in musts can also be useful to obtain low alcohol degree wines. In their work, Pickering et al. [14] studied the use of an enzyme system (glucose oxidase (GOX)-catalase) to reduce the glucose content in must by converting it to gluconic acid. However, this method produces musts and wines with higher acidity due, precisely, to the higher content of gluconic acid (ca. $73 \mathrm{~g} / \mathrm{L}$ ). Another method is the use of aerobic yeasts (Pichia and Williopsis) that are capable of a limited ethanol production during the fermentation of must. These yeasts use sugars for cell growth with the production of esters and other flavors of wine with a minimal ethanol production. However, for the production of low alcohol wines $(<3 \%)$ non-traditional equipment is required to provide agitation and aeration during fermentation. Although these yeasts are capable of an extreme alcohol reduction, the high levels of esters produced may affect the wine flavor [15].

Processes involving membranes have also been used for reducing the sugar content. Since June 2010 the International Organization of Vine and Wine (OIV) introduced in the "International Code of Oenological practices" the application of membrane techniques for the treatment of musts and wine in order to enable the selective holding back or passing of some compounds. The objectives sought by the application of these techniques are: to elaborate more balanced wine or other vitivinicultural products in terms of organoleptic characteristics; to compensate effects of adverse weather conditions and climate change; and to resolve certain organoleptic issues; in addition to expand the techniques available for development of products more adapted to consumer expectations [6].

Membrane filtration has been applied to wine for a long time: cross - flow microfiltration (MF) and ultrafiltration (UF) to clarify white grape must [16], sugar concentration using nanofiltration (NF) [17] and reverse osmosis (RO) [18] in musts. Reverse osmosis is also used to reduce alcohol in wines, but the problem is that RO membranes are permeable to both alcohol and water, and after the filtration it is necessary to add water again to the dealcoholized wine which creates legal problems in some countries where the addition of water is forbidden by law [19]. Membrane processes, namely dialysis [19], pervaporation [20] and vacuum membrane distillation 
[2] are also being used to get low-alcohol drinks. The advantage of the use of membrane technologies in the food industry, is that the high sugar containing byproducts could be used to manufacture liquors or as additives to other foodstuffs [21] Concentrated must plays an important role in the beverage and wine industry; it is a natural sweetener in wine production, and a vitamin- and aroma-rich drink [22].

According to the molecular weight of the sugars (i.e. glucose and fructose) present in grape must, nanofiltration should be the membrane process to be chosen to retain them [21].

In their studies, Garcia - Martin et al. [21] analyzed the use of different ultrafiltration and nanofiltration membranes to control the sugar content in must. Specifically, they studied the retention of glucose and fructose in model solutions and commercial musts. Also the rejection of the most important high and low molecular weight compounds was analyzed in this work. The results showed that nanofiltration is the most appropriate technique for controlling sugars and a moderate retention of low molecular weight compounds.

Moreover, in their research Kiss and coworkers [22] regulated the resulting sugar content of must to allow its preservation. They concluded that NF is a process alternative to conventional evaporation attending to economic considerations. Nanofiltration has also been used to increase the sugar content of grape must (to increase the final alcohol degree) in wine production [17]. Using a two stage NF process of grape must, Versari, et al. [17] obtained relatively high sugar retentions (7$97 \%$ ) with low retention of malic acid (ranging from $2 \%$ to $14 \%$ ).

In subsequent work García - Martin and coworkers $(2010,2011)[10,19]$ studied the sugar reduction in musts by nanofiltration to obtain wines with a slight alcohol reduction. Specifically, sugar reduction was achieved by two successive nanofiltration steps. To this end, they worked with two types of musts: one white, from Verdejo grape variety, and one red from Tinta de Toro grapes. In the first stage untreated must is filtered to obtain a retentate rich in sugars and high molecular weight compounds and a permeate with a medium sugar content. In the second stage the first permeate is filtered providing a second retentate and a second permeate with a low sugar content. The results showed that the second permeate mixed with untreated must or with the retentate of the first nanofiltration stage in adequate proportions reduced the alcohol content of the resulting wines by $2^{\circ}$.

However, during this experience some problems present in membrane separation processes were observed. The most relevant were:

- $\quad$ Fouling due to accumulation of particles of high molecular weight on the surface of the membranes. 
- $\quad$ Slender decompensation of certain charged substances after the filtering process such as potassium, malic and tartaric acids, which are important for the organoleptic properties of wine.

- $\quad$ Problems of the proposed filtration process: volume losses, high filtration times and temperature increase of the must which could promote alterations to it.

- A slight loss of color and aromatic intensity of the wine obtained from the mixture of must in wine compared to the control.

\subsection{Grape must and its composition}

Grapes and grape must are the most important raw material for wine elaboration. A good understanding of grape composition is essential to understand the process of winemaking and the quality of the resulting product. For the purpose of this thesis the knowledge of the different compounds of grape must is important in order to understand not only their significance in the obtained wine but to assess their influence during the membrane processes carried out.

In the resolution Oeno 18/73, of the International code of eonological practices created by the International Organization of Vine and Wine (OIV), grape must is defined as "liquid product obtained from fresh grapes, whether spontaneously or by physical processes such as: crushing, removing stems from grape berries or crushed grapes, draining, pressing" [6].

Even within the same winemaking region, must composition varies according to several factors, such as:

- The type and variety of grapes used.

- The ripeness and health of the grapes (ripeness depends on a range of factors, such as the climate during the growing season, the type of soil, and the fertilizers used).

- The pressure exerted on the grapes.

Table 1.1 shows the average quantitative composition and characteristics exhibited as substances or groups of substances. 
Table 1.1 Average quantitative composition of grape must [23]

\begin{tabular}{ll}
\hline $\mathbf{p H}$ & $3-4.5$ \\
\hline Water & $700-800 \mathrm{gL}^{-1}$ \\
\hline Sugars & $140-250 \mathrm{gL}^{-1}$ \\
\hline Organic acids & $4-17 \mathrm{gL}^{-1}$ \\
\hline Nitrogen compounds & $4-7 \mathrm{gL}^{-1}$ \\
\hline Polysaccharides & $3-5 \mathrm{gL}^{-1}$ \\
\hline Minerals & $0.8-2.8 \mathrm{gL}^{-1}$ \\
\hline Polyphenols & $0.5 \mathrm{gL}^{-1}$ \\
\hline Vitamins & $0.25-0.8 \mathrm{gL}^{-1}$ \\
\hline Aromatic compounds & $<0.5 \mathrm{gL}^{-1}$ \\
\hline
\end{tabular}

\subsubsection{Carbohydrates: Sugars in must}

The generic term carbohydrates encompasses a wide variety of very important compounds of highly complex composition which are found in grapes and wine. The carbohydrate content of both, grapes and wine, is very important in winemaking as these compounds intervene in practically all the molecular processes that occur from the onset of berry ripening to the transformation of must into wine. They are also key to the quality of the final product because they influence alcohol content, flavor and other organoleptic properties, and clarity.

Carbohydrates can be classified by size, with a distinction being made between monosaccharides, oligosaccharides (di or trisaccharides), and polysaccharides (>10 monomers). Winemakers, however, tend to classify carbohydrates according to their origin and biological function as shown in Table 1.2 [24].

Table 1.2 Classification of carbohydrates in winemaking according to origin and biological function [24]

\begin{tabular}{ll}
\hline \multirow{2}{*}{ Simple sugars } & Fermentable \\
\cline { 2 - 2 } $\begin{array}{l}\text { Monosaccharide and oligosaccharide } \\
\text { derivatives }\end{array}$ & Derived from the vine \\
\cline { 2 - 2 } Polysaccharides & Derived from microorganisms \\
\cline { 2 - 2 } & Derived from plant cell wall structures \\
\hline
\end{tabular}

Simple sugars belonging to the hexoses are easily metabolized by yeasts and bacteria, and are also known as fermentable sugars. Glucose, fructose, and mannose, 
which have analogous configurations, are the most relevant simple hexoses in the study of grapes and wines.

Galactose can also be fermented by certain strains of yeast, albeit with difficulty and only after a period of adaptation to the medium.

Small quantities of pentose sugars such as arabinose, xylose, and ribose are naturally non fermentable monosaccharides present in must and wine [25].

The main disaccharides found in grapes and wine are sucrose and trehalose, although maltose, melibiose, and lactose may also be present. Trehalose is a fermentable disaccharide and sucrose is hydrolyzed in the berries by the enzyme invertase to glucose. There have also been reports of small quantities of the trisaccharide raffinose which is hydrolyzed to fermentable sugars.

Other carbohydrates found in musts and wines are polysaccharides, which are derived from berry or yeast cell walls, or from the microbial flora present on the grape. These materials are formed from an enormous variety and number of monomers, have a high molecular weight, and are extremely complex in terms of composition, structure, and properties. Polysaccharides are high-molecular-weight carbohydrates formed by the polymerization of monosaccharides or monosaccharide derivatives via glycosidic bonds. They are a key component of the cell wall of grapes and are therefore indirectly related to the extraction of the color and odorant compounds from these cells. Their presence in must and wine is due to the degradation and solubilization of a portion of the pectins found in the cells of grape skin and pulp. The classification of polysaccharides has always been subject to debate. In certain wine fields, they are divided into pectins and gums [24, 25].

Among the carbohydrates of interest to winemakers the most abundant sugars in grapes are $[23,24]$ :

- Glucose: 6-carbon aldose (dextrose)

- Fructose: 6-carbon ketose (levulose)

Therefore, the term "sugars" along the present PhD thesis will refer to the concentration of glucose and fructose.

Sugars are produced during photosynthesis, a process that occurs in the green, chlorophyll- containing organs of the plant. Most of the sugar produced is transported from the photosynthetic organs to the rest of the plant in the form of sucrose. The berries continue to accumulate sugar as they ripen. The final concentration is related to photosynthetic activity, but it can be adversely affected by climate factors such as rainfall or temperature. 
The glucose to fructose $(G: F)$ ratio in ripened berries tends to 1:1.

During fermentation, yeasts can grow in aerobic conditions, producing $\mathrm{CO}_{2}$ and $\mathrm{H}_{2} \mathrm{O}$, or in anaerobic conditions, producing ethanol and $\mathrm{CO}_{2}$ as waste products [26]. The general fermentation reaction is shown below:

$$
\mathrm{C}_{6} \mathrm{H}_{12} \mathrm{O}_{6} \rightarrow 2 \mathrm{CH}_{3} \mathrm{CH}_{2} \mathrm{OH}+2 \mathrm{CO}_{2}
$$

Therefore, sugar levels indicate potential alcohol yield after fermentation and the likelihood of residual sugars remaining $[4,25]$. The sugar content of the juice is often expressed in terms of ${ }^{\circ}$ Brix which represent grams of sugar per 100 grams of juice.

\subsubsection{Organic acids}

The principal organic acids found in grapes are tartaric, malic, and to a small extent, citric. The content of them can be measured by titration and expressed as total acidity (TA). During the early period of berry growth, concentration of both acids increases in the fruit. During ripening, as the sugar accumulates in the fruit, the acid concentration decreases. The reduction of TA during maturation is related to the respiration rate of the berry and is a function of temperature [4]. Generally the reduction in malic acid is greater, and consequently, at maturity, the fruit contains more tartaric acid than malic.

\subsubsection{Minerals}

The mineral content of must and wine refers mainly to the cations and elements that these contain. Musts contain many mineral substances, which can be classified according to their electric charge and abundance as shown in Table 1.3 [23].

Table 1.3 Classification of minerals in musts

\begin{tabular}{ccc}
\hline Abundance & Cation & Anion \\
\hline Abundant & $\begin{array}{c}\mathrm{K}^{+} ; \mathrm{Na}^{+} ; \mathrm{Ca}^{2+} ; \mathrm{Mg}^{2+} ; \mathrm{Si}^{4+} \\
\text { Plant } \mathrm{macronutrients}^{2+}\end{array}$ & $\mathrm{PO}_{4}{ }^{3-} ; \mathrm{SO}_{4}{ }^{2-} ; \mathrm{Cl}^{-}$ \\
\hline Less abundant & $\mathrm{Mn}^{2+} ; \mathrm{Zn}^{2+} ; \mathrm{Al}^{3+} ; \mathrm{Cu}^{2+} ; \mathrm{Ni}^{2+} ;$ & \\
& $\mathrm{Li}^{+} ; \mathrm{Mo}^{4+} \mathrm{Co}^{2+} ; \mathrm{V}^{3+}$ \\
& $\mathrm{Plant} \mathrm{micronutrients}^{-} ; \mathrm{I}^{-}$ \\
\hline $\begin{array}{c}\text { Trace levels } \\
(\mathbf{p p b})\end{array}$ & $\mathrm{Pb}^{2+} ; \mathrm{As}^{3+}, \mathrm{Cd}^{2+}, \mathrm{Se}^{4+} ;$ \\
$\mathrm{Hg}^{2+} ; \mathrm{Pt}^{2+}$ & \\
\hline
\end{tabular}


Must and wine contain inorganic anions derived from dissociation of the soluble salts that form inorganic acids and the metal cations absorbed from the soil by the roots of the vine. The mineral or inorganic anions represent a small fraction of the total anion content of the must and wine, in which most anions are organic.

Contrary, metal cations present in wine are important because they form relatively insoluble salts with certain anions. The alkaline cations $\mathrm{K}^{+}$and $\mathrm{Na}^{+}$, the alkaline earth metals $\mathrm{Ca}^{2+}$ and $\mathrm{Mg}^{2+}$, and the metal ions $\mathrm{Fe}^{3+}$ and $\mathrm{Cu}^{2+}$ are particularly important. Potassium is the main cation present in wine [27]. During ripening, the potassium content of the grape increases. Its movement into fruit leads to the formation of potassium bitartrate, which reduces the acidity and increases the juice $\mathrm{pH}$. Therefore, it is important to control the concentrations of potassium and calcium to prevent precipitation of bitartrate and tartrate, respectively. However, other metals particularly iron and copper, can affect the clarity of wines and cause the appearance of a type of haze known as casse.

\subsubsection{Nitrogen compounds}

The main nitrogen compounds found in must are amino acids, either in free form or as polypeptides or proteins. Nitrogen compounds can be classified as mineral or organic. Mineral compounds are essentially formed by the ammonium ion $\left(\mathrm{NH}_{4}{ }^{+}\right)$, which is generated when ammonium salts are dissolved in water. Organic compounds, in contrast, are carbon and hydrogen compounds that contain a nitrogen atom.

Table 1.4 Nitrogen fractions of interest in winemaking [28]

\begin{tabular}{ccc}
\hline Fraction & Compounds & $\begin{array}{c}\text { Used by } \\
\text { microorganisms }\end{array}$ \\
\hline Inorganic nitrogen & $\begin{array}{c}\text { Ammonia }\left(\mathrm{NH}_{3}\right) \\
\text { Ammonium }\left(\mathrm{NH}_{4}{ }^{+}\right)\end{array}$ & Easily assimilated \\
\hline & Amino acids with molecular \\
weight $<200 \mathrm{Da}$ \\
Organic nitrogen & $\begin{array}{c}\text { Polypeptides with molecular } \\
\text { weight }=200-10000 \mathrm{Da}\end{array}$ & Non - assimilable \\
& Proteins with molecular & \\
& weight $>10000 \mathrm{Da}$ & \\
\hline
\end{tabular}

Nitrogen containing compounds are important because they serve as the nutrient for yeast and lactic acid bacteria. Nitrogen influences biomass formation (cell population or cell yield), rate of fermentation, and production of various byproducts, which in turn affects the sensory attributes of wine. Insufficient nitrogen in must can 
stuck fermentation. Therefore, another classification system, which is of more interest in winemaking, is based on how nitrogen compounds are used by microorganisms; that is, it distinguishes between assimilable and non-assimilable compounds. Examples of the former are the ammonium ion and free amino acids, and examples of the latter are peptides and proteins $[23,28]$ as shown in Table 1.4 .

\subsubsection{Phenolic compounds}

Grapes acquire their color from different compounds in the berries. The most noteworthy of these are [23]:

- Chlorophyll

- Carotenoids

- Betalains

- Polyphenols

Polyphenolic compounds play an essential role in both grapes and wine, as they are responsible for sensory properties, such as appearance (color), taste (astringency, bitterness), and aroma (volatile phenols). They can be mainly classified as:

- Simple (non-flavonoid) polyphenols

- Flavonoids

Figure 1.1 exhibits the phenolic compounds that are present at the highest concentrations, their role and location in grapes.

Polyphenols are primarily located in the seeds and skins of the berry and they are by-products of sugar catabolism. They are formed from the beginning of development in all of the organs of the vine. From veraison to the ripened grape, the skin becomes progressively enriched in phenolic compounds. The anthocyanins appear during veraison and are responsible for the characteristic color change observed during this physiological phenomenon; they then accumulate during ripening and are partially degraded at the end of the process. The tannins in the skin exhibit a similar temporal profile although they are already found at notable concentrations during veraison [29]. 


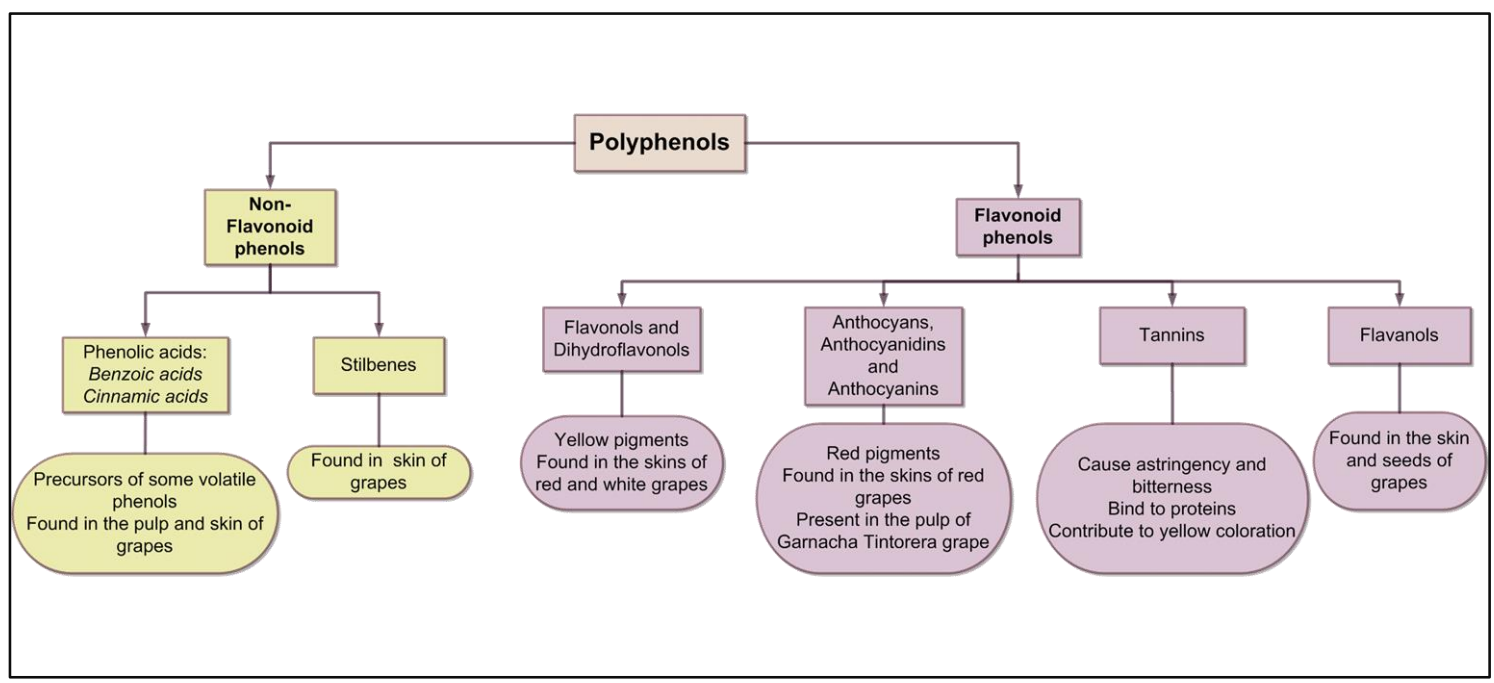

Figure 1.1 Summary of the main polyphenols found in grapes

\subsubsection{Aromatic compounds}

Aroma is one of the most important factors determining a wine's character and quality. There is a direct relationship between wine character and grape/must volatile composition [30].

Substances that contribute to the aroma of musts can be classified according different criteria. For the purpose of the present thesis, aromatic compounds have been divided into two main categories:

- those that are already present in the grapes: terpenes, carotenoids, and pyrazines

- those that are generated during must extraction and as a result of the treatments applied prior to fermentation: C6-alcohols, benzene compounds and aldehydes [31, 32].

These aromatic components are present in the berry in their free form, playing a key role in the quality and the peculiar aroma, or bound to sugar molecules in the form of glycosides being odourless [32-34].

\subsubsection{Terpens, Carotenoids and pyrazines}

Terpenes are usually found at concentrations below $1 \mathrm{mg} / \mathrm{L}$, and are more abundant in aromatic white grape varieties such as Muscat, Souvignon blanc, Riesling and Gewürztraminer. These compounds constitute the primary aroma of the wine and are largely responsible for the varietal character [4, 31]. As mentioned they can be present as free or glycosidically bound forms. Free terpenes are volatile and largely 
responsible for the distinctive aroma of grapes and must. Bound terpenes are nonvolatile and constitute what is known as the "hidden aroma" of the grapes. The concentration of bound terpenes begins to increase at veraison and exceeds that of free forms [31].

Carotenoids belong to the family of C40-terpenes. These substances are light sensitive and can be degraded by oxidases from the grape through a process of coupled oxidation that gives rise to $\mathrm{C} 9, \mathrm{C} 10, \mathrm{C} 11$, and $\mathrm{C} 13$ compounds that are more volatile, and more odorant than their precursors.

Pyrazines, specifically methoxipyrazines, are responsible of "vegetal" or "green" aroma in musts and wines from the Chardonnay, Riesling, Pinot Noir, and Gewürztraminer grape varieties. Usually they are present at levels below the perception threshold. Given the very low concentrations of these compounds in grapes and wine (a few nanograms per liter), they are very difficult to detect and quantify.

\subsubsection{C6-alcohols and aldehydes}

These compounds are generated through the activity of lipoxygenase enzymes present in the grapes. These enzymes come into contact with linoleic and linolenic (C18:2 and C18:3) fatty acids during pressing or crushing of the grapes generating saturated and unsaturated C6-alcohols and aldehydes. Hexanal, (E)-2-hexenal, (Z)- 3hexenal, hexanol-1, (E)-2-hexen-1-ol, and (Z)-3-hexen-1-ol have all been detected and mentioned as some of the characteristic aroma compounds in grape must [31, 32, 34]. The synthesis of these compounds is schematized in Fig. 1.2. This process occurs in the grape and it is enhanced by the mechanical processes that are used at different points between harvesting and alcoholic fermentation. These mechanical processes rupture the berries and cause release of the juice, and as a result, the fattyacid substrates come into contact with the relevant enzymes and give rise to the corresponding C6 compounds [31]. Oxygen plays a fundamental role in the production of these C6 compounds. Consequently, must from harvests that are subjected to intense mechanical processing, such as destemming, have higher concentrations than must from harvests that have not undergone such a process. Crushing also increases the levels of C6 compounds found in musts. Other factors that influence on the concentration of these compounds are for example the variety and ripeness of the grapes [32], climate and cultivar factors [34] treatments prior to fermentation, and temperature and duration of contact with the skins.

The presence of C6-alcohols and aldehydes compounds in grapes and must has been widely studied [32, 34], since they can potentiate the vegetal aroma and flavor that contributes undesirable sensory characteristics to the wine, despite being at 
very low concentrations. For example hexanol contributes as an aroma that is described in terms such as "green", "peanut", and "spicy", and it appears in wines at concentrations of between 0.3 and $12 \mathrm{mg} / \mathrm{L}$.

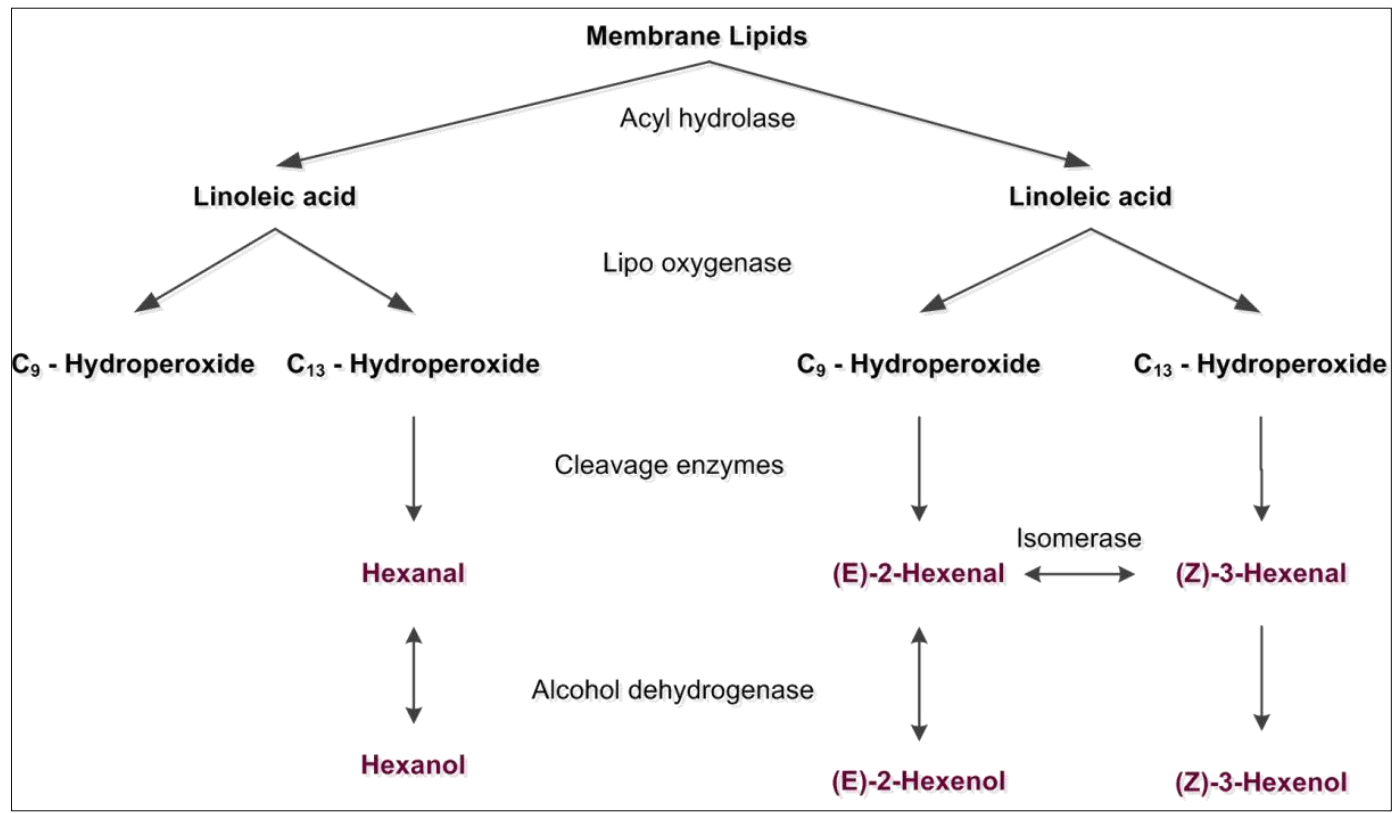

Figure 1.2 Synthesis of C6-alcohols and aldehydes in grapes [31]

Among all the aromatic substances and precursors mentioned here, C6alcohols and aldehydes are in general extremely volatile. The depletion of these compounds during beverage processing is often inevitable [35]. In this sense, the loss of them during nanofiltration of grape must will be studied in section III and IV of the present thesis in order to study the aroma depletion mentioned in Chapter 1.

\subsection{Aims and outline of the PhD thesis}

Now that the motivation of this thesis has been introduced, it is appropriate to define the aims of it.

The main objective of this work is to optimize the nanofiltration process for sugar control in grape must in order to produce full flavored wines with reduced alcohol content.

The specific aims (side objectives) established for the concretion of the main scope are: 
- $\quad$ To study the mass transfer and membrane fouling due to the presence of compounds with different molecular weight and chemical nature during the nanofiltration of grape must.

- To improve the filtration procedure and set-up in order to minimize volume losses, filtration times and temperature variations.

- $\quad$ To control the aroma depletion during the nanofiltration procedure.

For this purpose, the present work has been structured in five different sections. Section I is divided in two chapters. Chapter 1 is focused on the motivation of the present $\mathrm{PhD}$ thesis. It introduces the current problems related to the viticultural sector and to the methods and processes which are nowadays available to solve them. The different compounds present in grape must play an essential role not only in wine quality but also in the membrane processes involved in this work. Therefore Chapter 1 also provides a brief summary of grape must and its composition. Chapter 2 is aimed to present the general principles of the membrane processes used along this work.

Section II is focused on the study of the influence of the different molecular weight compounds present in grape must on the membrane and on permeate flux decrease. Chapter 3 entitled "Influence of low and high molecular weight compounds on the permeate flux decline in nanofiltration of red grape must" presents the development of a method proposed to study individually the influence of low and high molecular weight compounds on the permeate flux decrease during the nanofiltration of grape must. In Chapter 4, named "Fouling study of Nanofiltration membranes for sugar control in grape must. Analysis of resistances and the role of the osmotic pressure", the method proposed in Chapter 3 is used for the study and comparison of fouling, resistances to permeate flux and osmotic pressure generated during grape must filtration using different nanofiltration membranes. Section III, divided in two chapters, is focused on the scale-up of the nanofiltration process of grape must using the most appropriate membrane according the conclusions presented in Chapter 4. Therefore, the scope of Chapter 5 entitled "Comparative study of red grape must nanofiltration: Laboratory and pilot plant scales" is to analyze the main differences between red grape must nanofiltration at laboratory and at pilot plant scale using the same membrane. Specifically the hydrodynamics, fouling mechanisms, sugars rejection and osmotic pressure are compared. Furthermore, in Chapter 6 named "Alcohol reduction in red and white wines by nanofiltration of musts before fermentation" the first vintage and wine production during this thesis is described. This chapter is aimed to the selection of the most appropriate nanofiltration technique at pilot plant scale to reduce the alcohol content of wines by controlling the sugar content of the grape must before its 
fermentation. For that purpose the performance of single- stage and two-stage nanofiltration processes using a spiral wound unit were compared.

The scope of Section IV is to minimize the aroma depletion detected during nanofiltration. For that purpose, the use of pervaporation for aroma recovery of grape musts before the nanofiltration is proposed. In Chapter 7 entitled, "Experimental investigation of pervaporation membranes for aroma recovery of white grape must", the performance of different organophilic pervaporation membranes is analyzed for the recovery of primary aromas present in grape must. Chapter 8 named "Application of pervaporation and nanofiltration membrane processes for the optimization of sugar reduction in grape must in order to produce a full flavored low alcohol content wine" represents the scale-up of the best nanofiltration technique studied in Chapter 6. Here, the second vintage and wine production of the thesis is described. This chapter assesses the performance of the combination of pervaporation and nanofiltration at a higher pilot plant scale, for the elaboration of low alcohol content wine.

Finally, Section $\mathrm{V}$ brings together the main conclusions of this $\mathrm{PhD}$ thesis with a recapitulation of the main results gathered in order to fulfill the mentioned aims In accordance to these results a critical prospective of future research is also suggested here in order to enhance the membrane process proposed. 


\subsection{References}

[1] C. Lasanta, I. Caro, J. Gómez, L. Pérez, The influence of ripeness grade on the composition of musts and wines from Vitis vinifera cv. Tempranillo grown in a warm climate, Food Research International, 64 (2014) 432-438

[2] R. Mira de Orduña, Climate change associated effects on grape and wine quality and production, Food Research International, 43 (2010) 1844-1855.

[3] J. Hidalgo - Togores, Calidad del vino desde el viñedo, Mundi- Prensa, Madrid, 2006.

[4] D.I. Jackson, P.B. Lombard, Environmental and Management Practices Affecting Grape Composition and Wine Quality - A Review, American Journal of Enology and Viticulture, 44 (1993) 409-430

[5] A. Massot, M. Mietton-Peuchot, C. Peuchot, V. Milisic, Nanofiltration and reverse osmosis in winemaking, Desalination, 231 (2008) 283-289

[6] OIV, International Code of Oenological Practices, OIV, Paris, 2012.

[7] J. Masson, P. Aurier, F. d'hauteville, Effects of non-sensory cues on perceived quality: the case of low-alcohol wine, International Journal of Wine Business Research, 20 (2008) 215-229.

[8] J. Labanda, S. Vichi, J. Llorens, E. López-Tamames, Membrane separation technology for the reduction of alcoholic degree of a white model wine, LWT - Food Science and Technology, 42 (2009) 1390-1395.

[9] G.J. Pickering, Low- and Reduced-alcohol Wine: A Review, Journal of Wine Research, 11 (2000) 129-144.

[10] N. Garcia-Martin, S. Perez-Magarino, M. Ortega-Heras, C. Gonzalez-Huerta, M. Mihnea, M.L. Gonzalez-Sanjose, L. Palacio, P. Pradanos, A. Hernandez, Sugar reduction in white and red musts with nanofiltration membranes, Desalination and water treatment, 27 (2011) 167-174.

[11] Y.Y. Belisario-Sánchez, A. Taboada-Rodríguez, F. Marín-Iniesta, A. LópezGómez, Dealcoholized Wines by Spinning Cone Column Distillation: Phenolic Compounds and Antioxidant Activity Measured by the 1,1-Diphenyl-2-picrylhydrazyl Method, J. Agric. Food Chem., 57 (2009) 6770-6778

[12] S.V. Makarytchev, T.A.G. Langrish, D.F. Fletcher, Mass Transfer Analysis of Spinning Cone Columns Using CFD, Chemical Engineering Research and Design, 82 (2004) 752-761.

[13] M. Catarino, A. Mendes, Dealcoholizing wine by membrane separation processes, Innovative Food Science \& Emerging Technologies, 12 (2011) 330-337. 
[14] G.J. Pickering, D.A. Heatherbell, M.F. Barnes, Optimising glucose conversion in the production of reduced alcohol wine using glucose oxidase, Food Research International, 31 (1998) 685-692

[15] I.C. Huseyin Erten, The Production of Low-Alcohol Wines by Aerobic Yeasts, Journal of The Institute of Brewing, 107 (2001) 207 - 215.

[16] A. Cassano, A. Mecchia, E. Drioli, Analyses of hydrodynamic resistances and operating parameters in the ultrafiltration of grape must, Journal of Food Engineering, 89 (2008) 171-177

[17] A. Versari, R. Ferrarini, G.P. Parpinello, S. Galassi, Concentration of Grape Must by Nanofiltration Membranes, Food and Bioproducts Processing, 81 (2003) 275-278.

[18] A. Rektor, A. Kozak, G. Vatai, E. Bekassy-Molnar, Pilot plant RO-filtration of grape juice, Separation and Purification Technology, 57 (2007) 473-475 \%U http://www.sciencedirect.com/science/article/pii/S138358660600236X.

[19] N. García-Martín, S. Perez-Magariño, M. Ortega-Heras, C. González-Huerta, M. Mihnea, M.L. González-Sanjosé, L. Palacio, P. Prádanos, A. Hernández, Sugar reduction in musts with nanofiltration membranes to obtain low alcohol-content wines, Separation and Purification Technology, 76 (2010) 158-170

[20] L. Takács, G. Vatai, K. Korány, Production of alcohol free wine by pervaporation, Journal of Food Engineering, 78 (2007) 118-125.

[21] N. García-Martín, L. Palacio, P. Prádanos, A. Hernández, M. Ortega-Heras, S. Pérez-Magariño, D.C. González-Huerta, Evaluation of several ultra- and nanofiltration membranes for sugar control in winemaking, Desalination, 245 (2009) 554-558.

[22] I. Kiss, G. Vatai, E. Bekassy-Molnar, Must concentrate using membrane technology, Desalination, 162 (2004) 295-300.

[23] J. Moreno, R. Peinado, Chapter 2 - Composition of Grape Must, in: J. Moreno, R. Peinado (Eds.) Enological Chemistry, Academic Press, San Diego, 2012, pp. 13-22

[24] J. Moreno, R. Peinado, Chapter 6 - Sugars: Structure and Classification, in: J. Moreno, R. Peinado (Eds.) Enological Chemistry, Academic Press, San Diego, 2012, pp. 77-93.

[25] J. Moreno, R. Peinado, Chapter 7 - Sugars in Must, in: J. Moreno, R. Peinado (Eds.) Enological Chemistry, Academic Press, San Diego, 2012, pp. 95-107

[26] J. Moreno, R. Peinado, Chapter 11 - The Transformation of Must into Wine, in: J. Moreno, R. Peinado (Eds.) Enological Chemistry, Academic Press, San Diego, 2012, pp. 157-182

[27] J. Moreno, R. Peinado, Chapter 20 - Inorganic Material and Metal Casse, in: J. Moreno, R. Peinado (Eds.) Enological Chemistry, Academic Press, San Diego, 2012, pp. 355-373. 
[28] J. Moreno, R. Peinado, Chapter 12 - Nitrogen Compounds, in: J. Moreno, R. Peinado (Eds.) Enological Chemistry, Academic Press, San Diego, 2012, pp. 183-193

[29] J. Moreno, R. Peinado, Chapter 5 - Polyphenols, in: J. Moreno, R. Peinado (Eds.) Enological Chemistry, Academic Press, San Diego, 2012, pp. 53-76

[30] S.M. Rocha, P. Coutinho, A. Barros, I. Delgadillo, M.A. Coimbra, Establishment of the varietal volatile profile of musts from white Vitis vinifera $L$. varieties, Journal of the Science of Food and Agriculture, 87 (2007) 1667-1676

[31] J. Moreno, R. Peinado, Chapter 3 - Must Aromas, in: J. Moreno, R. Peinado (Eds.) Enological Chemistry, Academic Press, San Diego, 2012, pp. 23-39

[32] E.S. Palomo, M.C. Díaz-Maroto, M.A.G. Viñas, A. Soriano-Pérez, M.S. PérezCoello, Aroma profile of wines from Albillo and Muscat grape varieties at different stages of ripening, Food Control, 18 (2007) 398-403

[33] Y.Z. Gunata, C.L. Bayonove, R.L. Baumes, R.E. Cordonnier, The aroma of grapes I. Extraction and determination of free and glycosidically bound fractions of some grape aroma components, Journal of Chromatography A, 331 (1985) 83-90

[34] E. López-Tamames, N. Carro-Mariño, Y.Z. Gunata, C. Sapis, R. Baumes, C. Bayonove, Potential Aroma in Several Varieties of Spanish Grapes, Journal of Agricultural and Food Chemistry, 45 (1997) 1729-1735

[35] H.O.E. Karlsson, G. Tragardh, Applications of pervaporation in food processing, Trends in Food Science \& Technology, 7 (1996) 78-83 


\section{Chapter 2}

Nanofiltration and Pervaporation membrane processes

Basic principles 



\section{Chapter 2. Nanofiltration and Pervaporation membrane processes. \\ Basic principles}

\subsection{Introduction}

As mentioned in the first chapter, the scope of the present $\mathrm{PhD}$ thesis is to optimize the process of grape must nanofiltration in order to produce good quality wines with a reduced alcohol degree. Moreover, for this purpose the membrane technology pervaporation was also studied in this thesis in order to avoid the aroma depletion detected during nanofiltration. Therefore, the scope of this chapter is to collect the basic concepts and principles the membranes and membrane processes studied along this work: nanofiltration and pervaporation.

This part mentions the general principles and equations in a generic way; more details of them are shown in the corresponding chapter.

\subsection{Nanofiltration}

\subsubsection{Basic concepts}

Nanofiltration (NF) is a type of pressure-driven membrane process with properties in between reverse osmosis (RO) and ultrafiltration (UF) processes. The history of NF dates back to the 1970s when efforts started to develop RO membranes with a reasonable water flux at relatively low pressures. The high pressures used in RO resulted in a considerable energy cost, but, on the other hand, the quality of the obtained permeate was very good, and often even too good. Thus, membranes with lower rejections of dissolved components, but with higher water permeability, would be a great improvement for separation technology. Such low-pressure RO membranes became known as nanofiltration membranes [1].

The retention behavior versus pressure relationship reveals something of the nature of the separation mechanisms of a membrane. For example, with $\mathrm{RO}$ the solute retention increases with increasing pressure for most solutes which can be described by the non-porous Solution-Diffusion model, where solute and solvent are uncoupled. In contrast, for microporous UF the effect of pressure is often a decrease in the observed retention due to convective solute transport and concentration polarization effects. Figure 2.1 shows that NF behaves more like a non-porous $\mathrm{RO}$ membrane, in spite of the strong evidence for pores which characterize NF membranes. The similar behavior between the NF and RO can also be related to the importance acquired by 
the osmotic pressure in both processes. An increase of the applied pressure enhances the concentration polarization phenomenon which results in an increased osmotic pressure and the consequent reduction of the effective pressure. Usually in UF process the effects of the osmotic pressure are negligible.

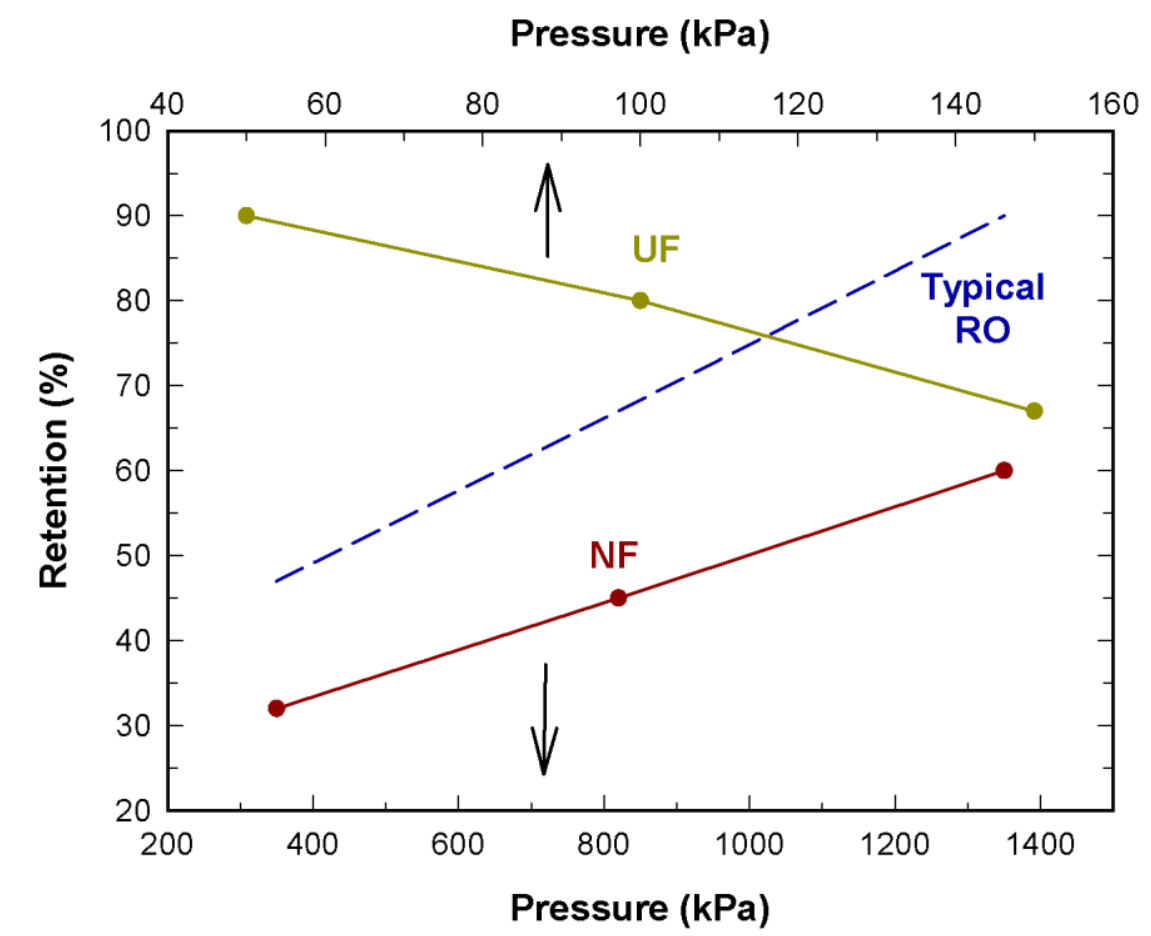

Figure 2.1 Retention as a function of transmembrane pressure. Trends for UF,NF and RO [2]

In fact, NF membranes possess pore size typically of $1 \mathrm{~nm}$ which corresponds to molecular weight cut-off (MWCO) of 150 [2]-500 [3] Da. Similar to RO membranes, NF membranes are potent in the separation of inorganic salts and small organic molecules. Key distinguishing characteristics of NF membranes are low rejection of monovalent ions, high rejection of divalent ions and higher flux compared to RO membranes. Therefore another distinctive feature of NF membranes is the rejection of ions with more than one negative charge like sulfate $\left(\mathrm{SO}_{4}{ }^{2-}\right)$ and phosphate $\left(\mathrm{PO}_{3}{ }^{4-}\right)$ which is virtually total $[2,4]$.

The market for NF membranes is growing dramatically. For example, by 2000 , the installed capacity was about $6000 \mathrm{ML} /$ day, which is 10 times higher than in 1990 [1]. Moreover, according to the market researcher bcc Research, the global membrane market was estimated to be valued at nearly $\$ 12$ billion in 2013. Nanofiltration membranes represent a very small share of this market (less than $2 \%$ ) but their market is growing at a faster rate compared to other membrane technologies. The increased market penetration of these products can be attributed to different factors, including a rising demand for potable water and reduced freshwater sources, environmental 
restrictions on industrial and municipal wastewater discharges, and lower operating costs compared to, for example, reverse osmosis [5]. In fact, as shown in Figure 2.2, the global market for nanofiltration membranes increased from \$172.8 million in 2012 to $\$ 190.2$ million in 2013 , and is estimated to grow to $\$ 445.1$ million by 2019 , with a five-year compound annual growth rate (CAGR) of $15.6 \%$.

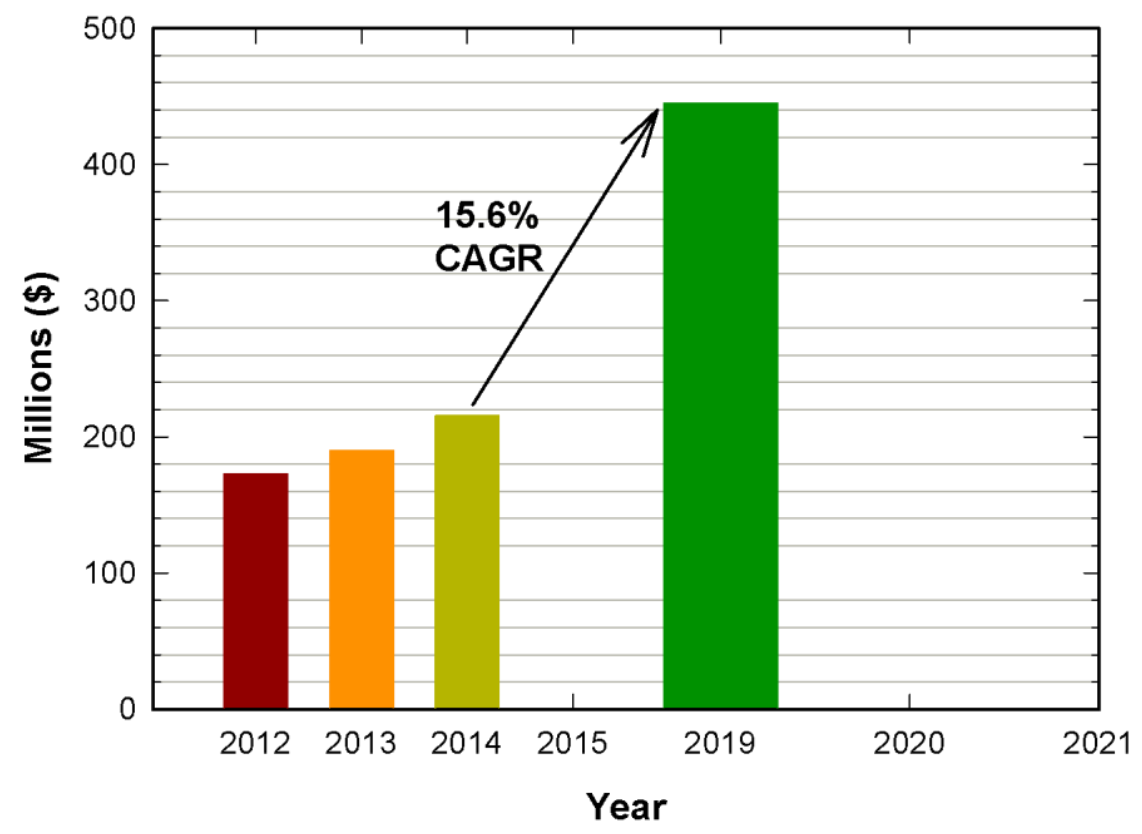

Figure 2.2 Global market for nanoniltration membranes, 2012-2019 [5]

NF is now widely used for water softening and has found application in the removal of natural organic matter and emerging pollutants such as pesticides in drinking water treatment. A wide range of process industry applications have been developed over the past decade [2]. Taking into account the number of possible applications, for example, the chemical and pharmaceutical industry, in addition to the applications that are still to be implemented but can be considered as state-of-the-art, it can be assumed that the increase of installed capacity will continue for many more years [1].

The development in NF membranes to the early 1990s has brought NF technology to its current status. As research continues, membranes become better defined, less prone to fouling, and more resistant to harsh conditions. More and more types, materials and configurations are used to prepare these membranes. Thus a NF membrane can be homogeneous or heterogeneous according to its morphology, symmetric (isotropic) or asymmetric (anisotropic) in structure and can be neutral or carry positive, negative or both charges. Among the anisotropic type, there are two 
important groups of NF membranes: thin film composite membranes (TFC) and integrally skinned asymmetric membranes.

A typical composite membrane consists of a thick, porous, nonselective supporting layer formed in a first process step, which is subsequently over coated with an ultrathin barrier layer on its top surface in a second process step. The multilayer approach allows a more flexible optimization of each layer. The supporting layer consists of a woven or a nonwoven fabric (commonly a polyester) overcoated with a layer of an asymmetric microporous polymer (usually polysulfone); this support layer should offer a maximal mechanical strength combined with a minimal resistance to permeation. The surface of the microporous support is coated with an ultrathin layer of a polymeric composition, which provides the controlling and permeability properties. The two layers are almost always different from one another in chemical composition. This contrasts with the second group mentioned, wherein a polymer-containing dope is cast into a homogeneous film by a single-step phase inversion method. A membrane of this latter type has an anisotropic structure consisting of a dense surface skin on a porous sublayer, both skin and sublayer having the same composition [2, 6]. Examples of the most used materials for NF membranes are cellulose acetate, polysulfones and polyamide [2, 3].

$\mathrm{NF}$ membranes in contact with an aqueous solution are also slightly charged due to the dissociation of surface functional groups or adsorption of charged solutes. For example, polymeric NF membranes contain ionizable groups such as carboxylic groups and sulfonic acid groups which result in charged surface in the presence of the feed solution. This is the reason why most of the NF membranes are highly effective in the ionic separation due to the electrostatic repulsion. This also allows working at lower pressures than for $\mathrm{RO}$ [7]. Normally the operating pressures are in the range 0.3 and 1.4 $\mathrm{MPa}$ [8]. The typical operating conditions in a NF process are: 1-4 MPa, $\mathrm{pH}$ between 2-11 and temperature up to $55^{\circ} \mathrm{C}$. These properties have allowed NF to be used in many applications and areas such as water and wastewater treatment, pharmaceutical and biotechnology, pulp and paper industry and food industry [2, 3].

\subsubsection{Separation mechanisms}

The ability of NF membranes for separating substances or complex solutions with charged and neutral substances is based on the different effects that influence separation mechanism and the combination of them. These are the steric, Donnan, dielectric and transport effects. The transport of neutral solutes is via the steric mechanism, this means that rejection depends on the molecular size and the pore 
diameter (size based exclusion). The Donnan effect describes the equilibria and membrane potential interactions between a charged species and the interface of the charged membrane. The membrane charge attributed to the dissociation of ionizable groups at the membrane surface and inside the membrane pores. The dissociation of these surface groups is strongly influenced by the $\mathrm{pH}$ of the contacting solution and where the membrane surface chemistry is amphoteric in nature, the membrane may exhibit an isoelectric point at a specific $\mathrm{pH}$. Electrostatic repulsion or attraction takes place according to the ion valence and the fixed charge of the membrane that may vary depending on the localized ionic environment as a result of the phenomena mentioned before [3]. The phenomena of dielectric exclusion are less understood and there are two main competing hypotheses for the exact nature of the interaction. These are the so called 'image forces' phenomenon and the 'solvation energy barrier' mechanism [8]. These describe effects associated with the dielectric constant material and dielectric constant change inside the pore. This transport model through the membrane is well described by the Nernst-Planck equation. An advanced form of this model for charged or uncharged solutes, which also takes into account the variation of concentration along the pores can be found in the work of Silva and coworkers [9]. In Chapter 4, a version for uncharged solutes of this model is used in order to determine the pore radii of NF membranes as a function of the rejection of solutes.

\subsubsection{Mass transport}

In general, in the filtration process of small and medium size molecules, for applied pressures $(\Delta p)$ over a certain critical value the permeability decreases until a more or less constant permeate flux is reached regardless of ulterior increases in $\Delta p$. This reduction of flux has been attributed to the phenomenon of concentration polarization, which is due to the building up of a layer of rejected solute in the boundary layer near the membrane surface. There are two fundamental factors that justify this [10-12]:

1. The osmotic pressure increase, $\Delta \pi$

2. The evolution of the total resistance of the membrane system, $R_{\text {sys }}$

When the overall process is taken into account, the evolution of the flux (flow per unit of area through the membrane and per unit time) can be written as: 


$$
J_{v}=\frac{\Delta p-\Delta \pi}{\eta_{f} R_{\text {sys }}}
$$

where $\Delta p$ is the applied transmembrane pressure, $\Delta \pi$ is the osmotic pressure gradient which depends on the concentration difference between both sides of the membrane, $\eta_{f}$ is the feed viscosity and, $R_{s y s}$ is the system resistance. $R_{s y s}$ is the sum of the membrane resistance, $R_{m}$ plus a series of terms that depend on the fouling caused by the solute (shape and size), the membrane itself (pore size, geometry and polymer) and their interaction (adsorption). This resistance will be once again mentioned in this chapter during the description of the membrane fouling mechanism and with more detail in Section II.

Assuming that the osmotic pressure follows the van't Hoff's law, the osmotic pressure difference generated by all components, can be calculated as:

$$
\Delta \pi=\sum_{i=1}^{n} \Delta \pi_{i}=\sum_{i=1}^{n} \frac{R T}{P M_{i}}\left(C_{m, i}-C_{p, i}\right)
$$

where $C_{m, i}$ is the concentration on the membrane surface and $C_{p, i}$ the permeate concentration of each component $\mathrm{i}$. In order to use this equation, it is necessary to know the concentration on the membrane active layer, $C_{m, i}$. This can be done by taking into account the concentration polarization model as described in the next paragraphs.

\subsubsection{Concentration Polarization. Film Theory}

The so called concentration polarization phenomenon inevitably appears in membrane processes such as NF since the selective transport causes an accumulation of the retained solutes in the adjacent membrane surface at the feed side. It results in the formation of a high solute concentration at the membrane surface compared to the bulk solution. Consequently, this polarization reduces the effectiveness of a membrane by: reducing the flow, decreasing separation capacity and increasing membrane fouling. The reduction of the separation capacity is not a result of the phenomenon of polarization itself. In an ideal separation process, the efficiency of a membrane is a constant factor related to the concentrations in both sides of the membrane. If the effects of concentration polarization increase the concentration on the side of high pressure it will consequently increase in the permeate side, reducing hence the efficiency. Concentration polarization can be reduced with an increase of the tangential 
velocity since this promotes shear (turbulence) on the retentate side and reduces the accumulation of solutes near the membrane.

The mentioned phenomenon can be studied by the Film theory. The later correlates the feed concentration, $C_{f, i}$, the concentration on the membrane active layer, $C_{m, i}$, the permeate flux and the retentate flux along the perpendicular to the membrane surface. This theory is based on the calculation of a mass transfer coefficient, $K_{m, i}$ in order to describe the solute transport $[12,13]$ as:

$$
C_{m, i}=C_{p, i}+\left(C_{f, i}-C_{p, i}\right) e^{\left(J_{v} / K_{m, i}\right)}
$$

here $K_{m, i}$ is the mass transfer coefficient of the $\mathrm{i}$-th component that can be evaluated from laborious experimental procedures such as velocity variations (velocity boundary layer) or concentration variation (concentration boundary layer) [4, 14]. A more simple method, which also implies greater error, is the use of an appropriate correlation of dimensionless numbers:

$S h=A \cdot \operatorname{Re}^{\alpha} S c^{\beta}$

where Sh, Re and Sc stand for the Sherwood, Reynolds and Schmidt numbers respectively. The constants $A, \alpha$ and $\beta$ can be different according to the system and process conditions under study. The values given to them will be explained in the different chapters of this thesis in accordance to the different conditions studied in each one of them.

\subsubsection{Fouling mechanisms}

The aforementioned resistance attributed to the fouling process, represents both, the reversible and irreversible fouling and depends on the fouling mechanism or mechanisms acting in the process. This resistance has been related with phenomena such as concentration polarization, gelation, deposition, adsorption of solute molecules inside the pores or pore blocking when the pore size is similar to the molecular dimensions [15-19]. All these processes should influence in a more or less balanced equilibrium, and they can be accounted by using several theoretical kinetic models commonly used for systems showing flux decline [18, 20].

The most usually followed models are: 
- Intermediate blocking

- Standard blocking

- Cake filtration

These three mechanisms can be described within the frame of the following expression:

$$
\frac{J_{v, 0}}{J_{v}}=(1+k t)^{n}
$$

where, $J_{v, 0}$ is the permeate flux per unit or area through the membrane at time $t=0$ in $(\mathrm{m} / \mathrm{s}) ; k$ is the general kinetic constant for the fouling models in $\left(\mathrm{s}^{-1}\right)$ and $n$ is a dimensionless exponent which depends of the fouling model.

The fouling mechanisms studied in the present thesis will be explained with more detail in Section II.

\subsection{Pervaporation}

\subsubsection{Basic concepts}

Pervaporation (PV) is a membrane separation process in which the components from a liquid mixture permeate selectively through a dense membrane [21]. When the membrane is in contact with the liquid mixture, one or more of the components can be preferentially removed from the mixture due to its higher affinity with, and/or quicker diffusivity in the membrane [22]. In contrast to pressure-driven membrane processes, the driving force of pervaporation is a chemical potential gradient between the feed and de permeate (downstream) side [23]. This difference is obtained by partial pressure reduction on the permeate side, which can be accomplished, for example, by applying vacuum or blowing a sweep inert gas on this side. The latter provides low driving forces for industrial applications; therefore vacuum pervaporation represents the common choice. Maintaining very low absolute pressures at the downstream side (133.3-400.0 $\mathrm{Pa}$ ) the continuous mass transport is ensured since all the molecules that migrate to the permeate face are removed. Therefore the concentration difference across the membrane is maintained [22]. The partial pressures of the permeant components are usually lower than their corresponding saturation pressures, and these components are 
therefore removed as vapor. The permeate is collected in traps, which at laboratory scale are normally cooled by using liquid nitrogen $(-196 \circ \mathrm{C})[21]$.

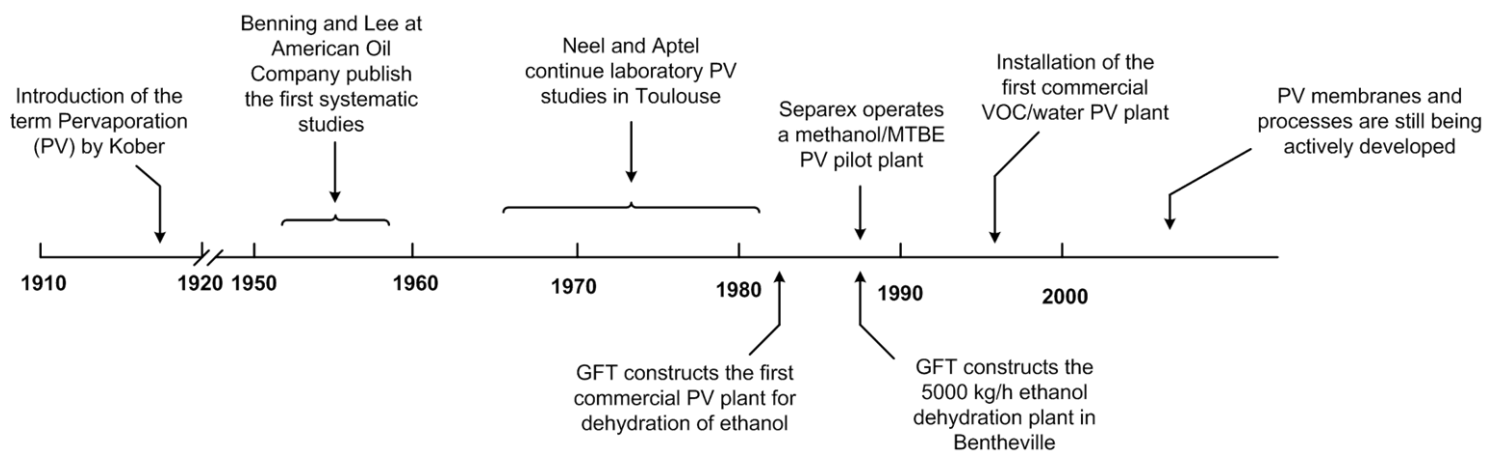

Figure 2.3 Milestones in the development of pervaporation [24]

As briefly shown in Figure 2.3, PV has been known to the scientific world since the early 1900s. In 1906 Kahlenberg reported some qualitative observations concerning the selective transport of hydrocarbon-alcohol mixtures through a thin rubber sheet. The term pervaporation was first introduced by Kober in a study published in 1917. In 1949 Schwob demonstrated dehydration of alcohols by using 20mm-thin membranes during his scientific work. In the early 1960s Binning and coworkers from The American Oil Company (Texas City, Texas), carried out several experiments to separate various hydrocarbons by using PV experiments. However, after several years of work, the technology was not commercialized. Academic research on pervaporation was also carried out by Aptel, Neel and others at the University of Toulouse [24, 25]. By the 1980s, advances in membrane technology made it possible to prepare economically viable pervaporation systems. Pervaporation systems are now commercially available for two applications. The first and most important is the removal of water from concentrated alcohol solution. In 1982 G.F.T., a German company now owned by Sulzer Chemtech, commercialized a PV plant for alcohol dehydration. This plant could produce $1300 \mathrm{~L}$ of ethanol per day of $99.2 \%$ purity from predistilled ethanol. The current largest plant was installed at Bethenville, France in 1988; this unit contains $2400 \mathrm{~m}^{2}$ of membranes and processes $5000 \mathrm{~kg} / \mathrm{h}$ of ethanol. The second commercial application of $\mathrm{PV}$ is the removal of small amounts of volatile organic compounds (VOCs) from contaminated water. This technology was developed by Membrane Technology and Research; the first commercial plant was sold in 1996. Current membrane technology makes PV systems also appropriate for the separation of organic/organic mixtures and the process is being actively developed by a number of companies. The first pilot-plant results for an organic-organic 
application, the separation of methanol from methyl tert-butyl ether/isobutene (MTBE) mixtures, was reported by Separex in 1988 [24, 25].

More recently, hydrophilic pervaporation has been used for the dehydratation of organic solvents and it is the most successful application of pervaporation [21, 22]. Several hundred plants have been installed for the dehydration of ethanol by pervaporation. This is a particularly favorable application for pervaporation because ethanol forms an azeotrope with water at $95 \%$ and a $99.5 \%$ pure product is needed. Because the azeotrope forms at $95 \%$ ethanol, simple distillation does not work. Morever, pervaporation has also been applied to dehydration of other solvents, particularly isopropanol which is used as a cleaning solvent. Dehydration of other solvents, including glycols, acetone and methylene chloride, has been considered. [24].

Organophilic membranes have been used for the recovery of high added-value components, such as aromas [26-28], but also for the removal of VOCs from either ground water [29] or aqueous effluents and process streams in the chemical industry [24]. In the food industry organophilic pervaporation has been used for the dealcoholization of beverages, such as wine and beer [30], it can also be employed for the separation of anhydrous organic mixtures [31,32] and the recovery of volatile flavor and aroma elements from streams produced in the processing of fruits and vegetables [24].

In pervaporation, asymmetric composite membranes are normally used. In this case, an integral asymmetric membrane formed by phase inversion technique is used as support, which is, afterwards, coated by an elastomeric polymer, forming a thin dense skin, the actual responsible for the membrane selectivity. The type of polymer used for the dense active layer determines the selectivity and hence the application of the membranes. There are two categories of membranes and thus the two aforementioned types of applications [33]. Hydrophilic polymers such as polyvinyl alcohol or cellulose acetate allow the permeation of water. Whereas hydrophobic polymers such as poly(dimethylsiloxane) (PDMS), poly(trimethylsilypropyne) (PTMSP) or poly(etherbolckamide) (PEBA) preferentially allow the permeation of organic substances.

\subsubsection{Mass transport. Solution - diffusion theory}

Solution-diffusion is the generally accepted mechanism of mass transport through non-porous (dense) membranes, which was first proposed by Graham [21, 22]. According to this mechanism, one or more components in a liquid mixture are transferred through the membrane in three steps [23, 34]: 
1. Sorption into the membrane polymer

2. Diffusion through the polymer film

3. Desorption and evaporation on the permeate side

The main parameters involved in sorption and diffusion steps are: temperature, pressure, concentration, molecular weight, size and shape of the molecule, polymer/penetrant compatibility, reticulation level and cristallinity of the polymer material. Sorption involves thermodynamic aspects (molecule penetration) while diffusion is related to kinetic factors (molecule mobility within the polymer) [21]. These three fundamental processes also govern the mass transport across pervaporation membranes. When a pervaporation membrane is in contact with a liquid feed mixture, it is generally assumed that the thermodynamic equilibrium is instantly reached at the membrane-feed interface, therefore [22]:

$$
\frac{C_{m, i}}{C_{f, i}}=K_{i}
$$

where $C_{\mathrm{m}, \mathrm{i}}$ and $C_{\mathrm{f}, \mathrm{i}}$ represent the concentrations of the species $\mathrm{i}$ in the membrane surface and the feed, respectively, and $K_{i}$ is thus the partition coefficient of this species between the membrane and the feed phase, which is a characteristic parameter dependent upon the interaction of the species with the membrane.

Assuming small concentration gradients through the membrane, diluted solutions and a negligible partial pressure of all compounds in the downstream side, membrane transport can be described by the Fick's first law [28] as:

$$
J_{i}=-D_{i, m} \frac{d C_{m, i}}{d x}
$$

where $J_{i}$ is the permeation flux of the $\mathrm{i}$-th species through the membrane, $D_{i, m}$ the diffusion coefficient of the $i$-th species in the membrane, and $x$ is the position variable. By introducing the partition coefficient $K$ of the species at the membrane/feed, and membrane/permeate interface, the concentrations of a species in the faces of the membrane can be expressed in its concentrations in the feed and the permeate, respectively, and the Fick's first law thus becomes:

$$
J_{i}=D_{i, m} K_{i} \frac{\Delta C_{i}}{x}=\frac{D_{i, m} K_{i}}{x} \Delta C_{i}
$$


where both the diffusion, and the partition coefficient are treated as constant. If the transmembrane concentration $\left(\Delta C_{i}\right)$ is taken as the driving force for the mass transport, the permeability of the i-th species in the membrane can thus be defined as:

$$
P_{i}=D_{i, m} K_{i}
$$

The permeability is an index for the measuring of the intrinsic mass transport capability of a membrane for a species. The ideal separation factor or selectivity of a membrane for species $i$ and $j$ can thus be defined as:

$$
\alpha_{i, j}=\frac{P_{i}}{P_{j}}=\frac{D_{i, m}}{D_{j, m}} \frac{K_{i}}{K_{j}}
$$

The performance of a PV process is often described by three parameters: The permeate flux, $J_{\mathrm{i}}$, The mass concentration enrichment factor, $\beta_{\mathrm{i}}$, for a component $\mathrm{i}$ and the selectivity $\mathrm{i}$ of a membrane for species $i$ in comparison to $j$. Experimentally these can be obtained respectively by:

$$
J_{i}=\frac{Q_{i}}{A_{m} \Delta t}
$$

and

$$
\beta_{i}=\frac{C_{f, i}}{C_{f, i}}
$$

where $Q_{i}$ is the quantity of permeate of i collected in a time interval $\Delta t, A_{m}$ is the effective membrane area, $C_{\mathrm{p}, \mathrm{i}}$ is the permeate and $C_{\mathrm{f}, \mathrm{i}}$ the mass concentration of $\mathrm{i}$ in the feed.

Finally, the ratio of enrichment factors of a compound $i$ and a compound $j$ indicates the selectivity, $\alpha_{i, j}$, that a membrane has for a compound $i$ in comparison with compound $\mathrm{j}$.

$$
\alpha_{i, j}=\frac{\beta_{i}}{\beta_{j}}
$$




\subsection{References}

[1] B. Van der Bruggen, J. Geens, Nanofiltration, in: Advanced Membrane Technology and Applications, John Wiley \& Sons, Inc., 2008, pp. 271-295.

[2] A.I. Schäfer, A.G. Fane, T.D. Waite, Nanofiltration: Principles and Applications, Elsevier Advanced Technology 2005.

[3] A.W. Mohammad, Y.H. Teow, W.L. Ang, Y.T. Chung, D.L. Oatley-Radcliffe, N. Hilal, Nanofiltration membranes review: Recent advances and future prospects, Desalination, 356 (2015) 226-254.

[4] W.S.W. Ho, K.K. Sirkar, Membrane Handbook, Van Nostrand Reinhold, New York, USA, 1992.

[5] B.C.C. Research, Global Markets and Technologies for Nanofiltration, in, June 2014.

[6] R.J. Petersen, Composite reverse osmosis and nanofiltration membranes, Journal of Membrane Science, 83 (1993) 81-150.

[7] N. Hilal, H. Al-Zoubi, N.A. Darwish, A.W. Mohamma, M. Abu Arabi, A comprehensive review of nanofiltration membranes:Treatment, pretreatment, modelling, and atomic force microscopy, Desalination, 170 (2004) 281-30.8.

[8] V. Silva, P. Prádanos, L. Palacio, J.I. Calvo, A. Hernández, Relevance of hindrance factors and hydrodynamic pressure gradient in the modelization of the transport of neutral solutes across nanofiltration membranes, Chemical Engineering Journal, 149 (2009) 78-86.

[9] V. Silva, Á. Martín, F. Martínez, J. Malfeito, P. Prádanos, L. Palacio, A. Hernández, Electrical characterization of NF membranes. A modified model with charge variation along the pores, Chemical Engineering Science, 66 (2011) 2898-2911..

[10] P. Pradanos, J.I. Arribas, A. Hernandez, Flux Limiting Factors in Cross-flow Ultrafiltration of Invertase through an Asymmetric Inorganic Membrane, Separation Science and Technology, 28 (1993) 1899-1911.

[11] P. Prádanos, J. de Abajo, J.G. de la Campa, A. Hernández, A comparative analysis of flux limit models for ultrafiltration membranes, Journal of Membrane Science, 108 (1995) 129-142.

[12] R.C. Kuhn, F. Maugeri Filho, V. Silva, L. Palacio, A. Hernández, P. Prádanos, Mass transfer and transport during purification of fructooligosaccharides by nanofiltration, Journal of Membrane Science, 365 (2010) 356-365.

[13] P. Prádanos, J.I. Arribas, A. Hernández, Retention of proteins in cross-flow UF through asymmetric inorganic membranes, AIChE Journal, 40 (1994) 1901-1910.

[14] M. Cheryan, Ultrafiltration and Microfiltration Handbook, CRC Press 1987. 
[15] M.W. Chudacek, A.G. Fane, The dynamics of polarisation in unstirred and stirred ultrafiltration, Journal of Membrane Science, 21 (1984) 145-160.

[16] L.J. Zeman, Adsorption effects in rejection of macromolecules by ultrafiltration membranes, Journal of Membrane Science, 15 (1983) 213-230.

[17] J.H. Hanemaaijer, T. Robbertsen, T. Van Den Boomgaard, C. Olieman, P. Both, D.G. Schmidt, Characterization of clean and fouled ultrafiltration membranes, Desalination, 68 (1988) 93-108.

[18] W.R. Bowen, J.I. Calvo, A. Hernández, Steps of membrane blocking in flux decline during protein microfiltration, Journal of Membrane Science, 101 (1995) 153-165.

[19] M.N.A. Seman, M. Khayet, N. Hilal, Nanofiltration thin-film composite polyester polyethersulfone-based membranes prepared by interfacial polymerization, Journal of Membrane Science, 348 (2010) 109-116.

[20] P. Prádanos, A. Hernández, J.I. Calvo, F. Tejerina, Mechanisms of protein fouling in cross-flow UF through an asymmetric inorganic membrane, Journal of Membrane Science, 114 (1996) 115-126.

[21] C.C. Pereira, C.P. Ribeiro Jr, R. Nobrega, C.P. Borges, Pervaporative recovery of volatile aroma compounds from fruit juices, Journal of Membrane Science, 274 (2006) 1-23.

[22] P. Shao, R.Y.M. Huang, Polymeric membrane pervaporation, Journal of Membrane Science, 287 (2007) 162-179.

[23] F. Lipnizki, J. Olsson, G. Trägårdh, Scale-up of pervaporation for the recovery of natural aroma compounds in the food industry. Part 1: simulation and performance, Journal of Food Engineering, 54 (2002) 183-195.

[24] R.W. Baker, Membrane Thecnology and Applications, 2nd ed., John Wiley \& Sons, Ltd, England, 2004.

[25] F.U. Baig, Pervaporation, in: Advanced Membrane Technology and Applications, John Wiley \& Sons, Inc., 2008, pp. 469-488.

[26] C. Brazinha, D.S. Barbosa, J.G. Crespo, Sustainable recovery of pure natural vanillin from fermentation media in a single pervaporation step, Green Chemistry, 13 (2011) 2197-2203.

[27] C. Brazinha, V.D. Alves, R.M.C. Viegas, J.G. Crespo, Aroma recovery by integration of sweeping gas pervaporation and liquid absorption in membrane contactors, Separation and Purification Technology 70 (2009) 103-111.

[28] Á.d. Olmo, C.A. Blanco, L. Palacio, P. Prádanos, A. Hernández, Pervaporation methodology for improving alcohol-free beer quality through aroma recovery, Journal of Food Engineering, 133 (2014) 1-8. 
[29] W. Ji, S.K. Sikdar, S.-T. Hwang, Modeling of multicomponent pervaporation for removal of volatile organic compounds from water, Journal of Membrane Science, 93 (1994) 1-19.

[30] L. Takács, G. Vatai, K. Korány, Production of alcohol free wine by pervaporation, Journal of Food Engineering, 78 (2007) 118-125.

[31] A. Rozicka, J. Niemistö, R.L. Keiski, W. Kujawski, Apparent and intrinsic properties of commercial PDMS based membranes in pervaporative removal of acetone, butanol and ethanol from binary aqueous mixtures, Journal of Membrane Science, 453 (2014) 108-118.

[32] S. Heitmann, V. Krüger, D. Welz, P. Lutze, Experimental Investigation of Pervaporation Membranes for Biobutanol Separation, Journal of Membrane and Separation Technology, 2 (2013) 245-262.

[33] H.O.E. Karlsson, G. Tragardh, Applications of pervaporation in food processing, Trends in Food Science \& Technology, 7 (1996) 78-83.

[34] B.K. Dutta, W. Ji, S.K. Sikdar, Pervaporation: Principles and Applications, Separation \& Purification Reviews, 25 (1996) 131-224. 

SECTION II. PERMEATE FLUX DECREASE DURING THE NANOFILTRATION OF GRAPE JUICE. STUDY OF THE INFLUENCE OF THE DIFFERENT MOLECULAR WEIGHT COMPOUNDS 



\section{Chapter 3}

\section{Influence of low and high molecular weight compounds on the permeate flux decline in nanofiltration of red grape must}

Camila M. Salgado ${ }^{1}$, Laura Palacio ${ }^{1}$, Francisco J. Carmona ${ }^{2}$, Antonio Hernández $^{1}$ and Pedro Prádanos ${ }^{1}$

${ }^{1}$ Grupo de Superficies y Materiales Porosos (SMAP), Dpto. Física Aplicada, Facultad de Ciencias, Universidad de Valladolid, 47071 Valladolid, Spain

${ }^{2}$ Dpto. de Física Aplicada. Esc. Politécnica. Universidad de Extremadura, 1003.

Cáceres, Spain.

This chapter has been published in:

Desalination 315 (2013) 124-134

DOI: http://dx.doi.org/10.1016/j.desal.2012.09.032 



\section{Chapter 3. Influence of low and high molecular weight compounds on the permeate flux decline in nanofiltration of red grape must}

\section{Abstract}

The individual influence of the main low molecular weight compounds present in red grape must, such as glucose and fructose, and the high molecular weight ones such as polyphenols, polysaccharides and proteins, on the permeate flux $\left(J_{v}\right)$ decline in the nanofiltration of red must was studied. For this purpose, a synthetic solution containing the typical low molecular weight compounds of natural must was nanofiltered. The results were compared with those obtained by the nanofiltration of commercial red must.

During red must filtration the formation and thickening of a gel layer on the membrane surface caused a rapid decrease in $J_{v}$ followed by a slow increase of sugars concentration in the retentate due to the small permeate volume recovery. Under these extreme conditions an analytical method was tested allowing the individual study of the resistances and fouling mechanism generated by the sugars and the high molecular weight solutes. The results proved that high molecular weight compounds have more influence on the permeate flux decrease since they are the main responsible of the fouling phenomenon (cake filtration fouling mechanism), while low molecular weight compounds contribute to the flux decay mostly through an increase of osmotic pressure during the process.

Keywords:

Red grape must, Nanofiltration, permeate flux decrease, Low molecular weight compounds, cake formation mechanism 


\subsection{Introduction}

Partly due to the climate change, the last years have been warmer and dryer in some regions. As a consequence of that, an early ripening of grapes takes place which increases sugar content. Thus, fermentation should lead to alcoholic degrees higher than desired [1]. A premature winemaking should affect the final wine quality, leading to more acid and less colored wines, because the phenolic maturity should not be fully achieved [2].

Over the past decade the interest and consumer demand for reduced-alcohol, 'low-alcohol' and dealcoholized wines have increased [3]. Some of the reasons are the social consciousness for the moderate consumption of alcohol, the regulations of these products $[4,5]$ and the demand of low calorie products [6]. But, at the same time, there is a growing demand, by consumers, of more powerful and full flavored wines that are achieved with greater maturity of the grapes, both skin and seeds. This means that producers struggle to achieve the same levels of phenolic ripeness and tannic characteristics without an increase in alcohol content. Therefore the harvest should be carried out in the optimum ripeness and then innovative techniques to reduce the final alcohol content should be used.

Wine producers have used many dealcoholisation processes or methods to produce low alcohol-content wine. The most used method in the industry is the spinning cone column (SCC). SCC is used in the food industry for the separation of volatile components from liquids and slurries. This procedure requires several steps to remove first the wine aromas and afterwards alcohol and finally the aromas are returned to the dealcoholized wine $[7,8]$. Because it is a time consuming and expensive process, other dealcoholization techniques have been used too. Some examples are the thermal processes such as distillation columns, evaporators, or freeze concentration [6]. Heat-based processes can produce wines with very low alcohol content $(<0.5$ vol. $\%)$, however most of the volatile aroma compounds are also lost during the ethanol removal [9].

An adequate control of sugars in musts can also be useful to obtain low alcohol degree wines. In their work, Pickering et al. [10] studied the use of an enzyme system (glucose oxidase (GOX)-catalase) to reduce the glucose content in must by converting it to gluconic acid. However, this method produces musts and wines with higher acidity due, precisely, to the higher content of gluconic acid (ca. $73 \mathrm{~g} / \mathrm{L}$ ). Another method is the use of aerobic yeasts (Pichia and Williopsis) that are capable of a limited ethanol production during the fermentation of must. These yeasts use sugars for cell growth with the production of esters and other flavors of wine with a minimal ethanol 
production. However, for the production of low alcohol wines $(<3 \%)$ non-traditional equipment is required to provide agitation and aeration during fermentation. Although these yeasts are capable of an extreme alcohol reduction, the high levels of esters produced may affect the wine flavor [11].

Processes involving membranes have also been used for reducing the sugar content. Since June 2010 the International Organization of Vine and Wine (OIV) introduced in the "International Code of Oenological practices" the application of membrane techniques for the treatment of musts and wine in order to enable the selective holding back or passing of some compounds. The objectives sought by the application of these techniques are: to elaborate more balanced wine or other vitivinicultural products in terms of organoleptic characteristics; to compensate effects of adverse weather conditions and climate change; and to resolve certain organoleptic issues; in addition to expand the techniques available for development of products more adapted to consumer expectations [12].

Membrane filtration has been applied to wine for a long time: cross - flow microfiltration (MF) and ultrafiltration (UF) to clarify white grape must [13], sugar concentration using nanofiltration (NF) [14] and reverse osmosis (RO) [15] in musts. Reverse osmosis is also used to reduce alcohol in wines, but the problem is that RO membranes are permeable to both alcohol and water, and after the filtration it is necessary to add water again to the dealcoholized wine which creates legal problems in some countries where the addition of water is forbidden by law [16]. Membrane processes, namely dialysis [16], pervaporation [17] and vacuum membrane distillation [1] are also being used to get low-alcohol drinks. The advantage of the use of membrane technologies in the food industry, is that the high sugar containing byproducts could be used to manufacture liquors or as additives to other foods [18]. Concentrated must plays an important role in the beverage and wine industry; it is a natural sweetener in wine production, and a vitamin- and aroma-rich drink [19].

Of course, if the molecular weight of sugars in must is taken into account, nanofiltration should be the membrane process to be chosen to retain them [18]. In their work, Kiss et al. [19] regulated the resulting sugar content to allow the preservation of must and they concluded that NF is a process alternative to conventional evaporation attending to economic considerations. Nanofiltration has also been used to increase the sugar content of grape must (to increase the final alcohol degree) in wine production[14]. Using a two stage NF process of grape must, Versari et al.[14] obtained relatively high sugar retentions (7-97\%) with low retention of malic acid (ranging from $2 \%$ to $14 \%$ ). 
In their work García - Martin, et al. [2, 16] studied the sugar reduction in musts by nanofiltration to obtain wines with a slight alcohol reduction. Specifically, sugar reduction was achieved by two successive nanofiltration steps. To this end, they worked with two types of musts: one from the Verdejo variety of white grapes and the other from red grapes of the Tinta de Toro variety. The results showed that the musts obtained from the nanofiltration treatment mixed with untreated must or with the retentate of the first nanofiltration stage in adequate proportions reduced the alcohol content of the resulting wines by $2 \stackrel{\circ}{\circ}$. However, a slight loss of color and aroma intensity and a slender unbalancing of some important substances (potassium, malic and tartaric acid) was detected. Moreover, these experiments of must nanofiltration, showed that there are some problems that are common in membrane separation processes, among them specially relevant trouble is caused by the permeate flux decline.

The aim of the present work is to study the influence in must nanofiltration of its main low molecular weight compounds in comparison to their higher molecular weight components. In particular we intended to analyze the reduction of the nanofiltration permeate volume flux $\left(J_{v}\right)$. For this purpose a synthetic solution containing the typical low molecular weight compounds (LMW) of natural must, namely glucose, fructose, malic and tartaric acids, potassium, sodium, calcium and magnesium was nanofiltered. The results were compared with those obtained from the filtration, under the same operation conditions, of commercial red must; which, besides the already mentioned solutes, contains high molecular weight compounds (HMW) such as polyphenols, polysaccharides and proteins.

\subsection{Theory}

\subsubsection{Permeate Flux Limit}

In general, in the filtration process of small and medium size molecules, for applied pressures $(\Delta p)$ over a certain critical value the permeability decreases until a more or less constant permeate flux is reached regardless of ulterior increases in $\Delta p$. This reduction of flux has been attributed to the phenomenon of concentration polarization, which is due to the building up of a layer of rejected solute in the boundary layer near the membrane surface. There are two fundamental factors that justify this [20-22]:

1. The osmotic pressure increase, $\Delta \pi$ 
2. The evolution of the total resistance of the membrane system, $R_{\text {sys }}$

When the overall process is taken into account, the evolution of the flux (flow per unit of area through the membrane and per unit time) can be written as:

$J_{v}=\frac{\Delta p-\Delta \pi}{\eta_{f} R_{\text {sys }}}$

where $\Delta p$ is the applied transmembrane pressure, $\Delta \pi$ is the osmotic pressure gradient which depends on the concentration difference between both sides of the membrane, $\eta_{f}$ is the feed viscosity and, $R_{s y s}$ is the system resistance. $R_{s y s}$ is the sum of the membrane resistance, $R_{m}$ plus a series of terms that depend on the fouling caused by the solute (shape and size), the membrane itself (pore size, geometry and polymer) and their interaction (adsorption), $R_{f}$ :

$$
R_{\mathrm{sys}}=R_{m}+R_{f}
$$

According to their different molecular weight, the solutes in red must would give two contributions to $R_{f}$ : the resistance due to the fouling by low, $R_{f L M W}$, and by high molecular weight compounds, $R_{f H M W}$, respectively.

$$
R_{f}=R_{\mathrm{fLMW}}+R_{\mathrm{fHMW}}
$$

Assuming that the osmotic pressure follows the van't Hoff's law, the osmotic pressure difference generated by all components, can be calculated as:

$$
\Delta \pi=\sum_{i=1}^{n} \Delta \pi_{i}=\sum_{i=1}^{n} \frac{R T}{P M_{i}}\left(C_{m, i}-C_{p, i}\right)
$$

where $C_{m, i}$ is the concentration on the membrane surface and $C_{p, i}$ the permeate concentration of each component $\mathrm{i}$. In order to use this equation, it is necessary to know the concentration on the membrane active layer, $C_{m, i}$. This can be done by taking into account the concentration polarization model as described in the next paragraphs. 


\subsubsection{Concentration Polarization. Film Theory}

The Film Theory correlates the feed concentration, $C_{o, i}$, the concentration on the membrane active layer, $C_{m, i}$, the permeate flux and the retentate flux along the perpendicular to the membrane surface. This theory is based on the calculation of a mass transfer coefficient, $K_{m, i}$ in order to describe the solute transport in the membrane active layer $[22,23]$ as:

$$
C_{m, i}=C_{p, i}+\left(C_{0, i}-C_{p, i}\right) e^{\left(J_{v} / K_{m, i}\right)}
$$

here $K_{m, i}$ is the mass transfer coefficient of the i-th component that can be evaluated by means of an appropriate correlation of dimensionless numbers for the system and process conditions:

$S h=A \cdot \operatorname{Re}^{\alpha} S c^{\beta}$

where $S h$ is the Sherwood number, $R e$ is the Reynolds number, $S c$ is the Schmidt number and $\alpha$ and $\beta$ are constants. They are defined as:

$$
\mathrm{Re}=\frac{V \rho_{f} d_{h}}{\eta_{f}} \quad S h=\frac{K_{m, i} d_{h}}{D_{i}} \quad S c=\frac{\eta_{f}}{\rho_{f} D_{i}}
$$

where, $v$ is the velocity inside the channel (average tangential velocity on the membrane surface), $\rho_{f}$ the density and $\eta_{f}$ the viscosity of the feed, $D_{i}$ the diffusion coefficient of the $i$-th component and $d_{h}$ the hydraulic diameter of the membrane channel. This diameter in terms of the transversal area, $A_{T}$, and the transversal perimeter of the channel, $P_{T}$, is:

$$
d_{h}=\frac{4 A_{\mathrm{T}}}{P_{\mathrm{T}}}
$$

The $K_{m, i}$ calculated according to Eq. (6) is the conventional mass transfer coefficient used for impermeable walls. In the case of semipermeable membranes, such as a nanofiltration membrane, this coefficient can be corrected applying the correction factor $\Xi_{i}$ as [24]: 
$K_{m, i}^{*}=K_{m, i} \Xi_{i}$

And defining:

$\phi_{i}=\frac{J_{v}}{K_{m, i}}$

For low permeation fluxes $\left(\Phi_{i} \leq 1\right)$, the correction factor can be calculated according to:

$$
\Xi_{i}=\phi_{i}+\frac{\phi_{i}}{e^{\phi_{i}}-1}
$$

The membrane efficiency can be evaluated by determining the time evolution of the true retention, $R_{i}$, of the $\mathrm{i}$-th component, which is calculated through the following equation:

$R_{i}=1-\frac{C_{p, i}}{C_{m, i}}$

\subsubsection{Fouling mechanism and models}

The additional resistance attributed to the fouling process involved, $R_{f}$, represents both, the reversible and irreversible fouling and depends on the fouling mechanism or mechanisms acting in the process. This resistance has been related with phenomena such as concentration polarization, gelation, deposition, adsorption of solute molecules inside the pores or pore blocking when the pore size is similar to the molecular dimensions [25-29]. All these processes should influence in a more or less balanced equilibrium, and they can be accounted by using several theoretical kinetic models commonly used for systems showing flux decline [28, 30].

The most usually followed models can be described within the frame of the following expression:

$\frac{J_{v, 0}}{J_{v}}=(1+k t)^{n}$ 
where, $J_{v, 0}$ is the permeate flux per unit or area through the membrane at time $t=0$ in $(\mathrm{m} / \mathrm{s}) ; k$ is the general kinetic constant for the fouling models in $\left(\mathrm{s}^{-1}\right)$ and $n$ is a dimensionless exponent which depends of the fouling model.

Assuming that each particle can settle on other particle previously arrived and already blocking some pores or it can also directly block some membrane area, the resulting model corresponds to the so called "intermediate blocking" phenomenon $(\mathrm{n}=1)$. In this case the kinetic constant, $k_{i}\left(\right.$ in $\left.^{-1}\right)$, appears as:

$$
k=k_{i} \cdot J_{v, 0}
$$

This kinetic constant represents the membrane surface blocked per unit of total volume permeated through the membrane.

It is also possible that each particle arriving to the membrane was deposited onto the internal pore walls leading to a decrease in the pore volume. Moreover, if the membrane is supposed to consist in a bunch of equal cylindrical pores, it occurs the so called "standard blocking" phenomenon $(n=2)$. With $k$ being:

$$
k=\frac{1}{2} A_{m} J_{v, 0} k_{s}
$$

$A_{m}$ is the membrane and $k_{S}$ (in $\mathrm{m}^{-3}$ ) is the kinetic constant for this model [28].

Finally, if each particle locates on others already arrived and already blocking some pores and there is no room for a direct obstruction of any membrane area. In such a way the resulting mechanism corresponds to the "cake filtration" model $(n=1 / 2)$. In this case the kinetic constant is $k_{C}$ (in $\mathrm{s} / \mathrm{m}^{6}$ ) that is correlated with the $\mathrm{k}$ constant of Eq.(13) by:

$$
k=2 A_{m}^{2} J_{v, 0}^{2} k_{c}
$$

Actually none of these models predicts usually a complete flux decline curve for the whole time range which seems to be rather divided into several successive steps [28, 30, 31]. The predominant mechanism and the sequential appearance of them would depend on the size relation within the solute and the pore and on the solutemembrane interaction. For big solutes as those characterizing musts a pore blocking mechanism normally should appear first followed by the formation of a cake that would dominate most of the filtration kinetics. The standard blocking doesn't appear usually for nanofiltration because solute and pore sizes are comparable. 
For the intermediate blocking mechanism the integration of Eq. (13) with $n=1$ gives:

$\ln J V=-k_{i} V_{p}+\ln J_{v, 0}$

While for the cake model, with $n=1 / 2$ :

$\frac{t}{V_{p}}=\frac{k_{c} \cdot A_{m}^{2}}{2} V_{p}+\frac{1}{J_{v, 0}}$

where $V p$ is the permeate volume. Both the equations (17) and (18) should allow linear plots to obtain the corresponding kinetic constants.

Depending on the foulants characteristics (molecular weight and size) and the interactions between foulant - foulant (if they form loose coloids or more coiled molecules) and foulant - membrane (if the cake is cohesively bounded to the membrane or not), the cake layer formed on the membrane surface may be compressible and become more compact and dense after a certain period of filtration time. If the cake is compressible, Schippers and Verdouw [32] described that a third mechanism may occur during the flux decline, the so called "cake filtration with compression model". In that case, the slope of the plot of Eq. (18) can gradually change to an empirical form as:

$\frac{t}{V_{p}}=\frac{k_{c} \cdot A_{m}^{2}}{2}\left(1+\Delta P^{a}\right)+\frac{1}{J_{v, 0}}$

where $a$ is a constant dependence on the compressibility of the cake.

\subsection{Materials and Methods}

\subsubsection{Membrane and Experimental Setup}

The nanofiltration membrane used for the filtrations was a NF270, made and commercialized by Dow- Filmtec. The main nominal properties of the membrane are shown in Table 3.1. The membrane selection criterion was based on two aspects. First, the ratio between its MWCO (Table 3.1) and the molecular weight of glucose and fructose $(180 \mathrm{~g} / \mathrm{L})$. The second factor was based on the results obtained by Kuhn et al [22] were the NF270 presented the highest glucose and fructose retention values 
between five other nanofiltration membranes. Furthermore, this membrane has a higher permeability and undergoes less fouling than the membrane used in previous studies [2,16].

Table 3.1. Manufacturer's nominal data of the membrane NF270

\begin{tabular}{|c|c|c|c|c|c|c|}
\hline Membrane & $\begin{array}{c}\text { MWCO } \\
\text { (Da) }\end{array}$ & $\begin{array}{c}\text { Water } \\
\text { Permeability } \\
\left(10^{-11} \mathrm{~m} / \mathrm{Pa} \mathrm{s}\right)\end{array}$ & $\begin{array}{c}\text { Max. } \\
\text { pressure } \\
\left(10^{5} \mathrm{~Pa}\right)\end{array}$ & $\begin{array}{c}\text { Max. T } \\
\quad\left({ }^{\circ} \mathrm{C}\right)\end{array}$ & $\begin{array}{c}\mathrm{pH} \\
\text { range }\end{array}$ & $\begin{array}{c}\text { Rejection } \\
\text { (\%) }\end{array}$ \\
\hline NF270 & $300-400$ & $3.62^{a}$ & 41 & 45 & $3-10$ & $85^{b}$ \\
\hline
\end{tabular}

The experimental set-up used for must filtration is shown in Figure 3.1.

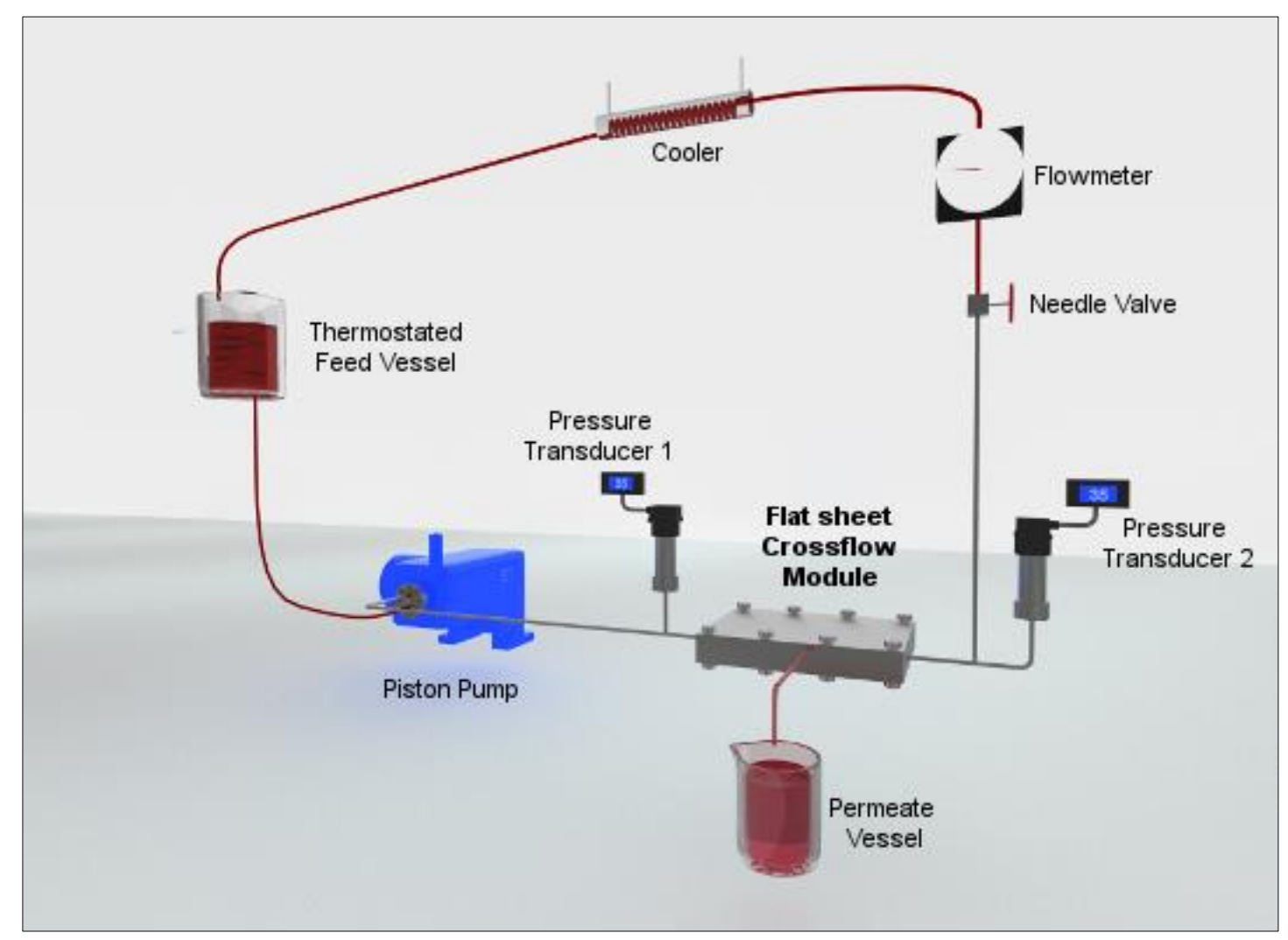

Figure 3.1. Diagram of the experimental setup used in the nanofiltration processes

It consists of a feed vessel, with a cryogenic unit to maintain the feed temperature at $20^{\circ} \mathrm{C}$. The feed was extracted from the thermostated reservoir by means of a regulatable piston pump Hydra - Cell G03. The retentate flow was measured with a flowmeter ranging from 0 to $10 \mathrm{~L} / \mathrm{min}$. Two pressure transducers were placed before and after the membrane module to measure the inlet and outlet pressure. In order to control the pressure inside the module, a needle valve was used. In this flow range the pressure drop across the cell is small enough to assume that the 
pressure drop through the membrane is approximately equal to that indicated by the input and output transducers. Since the retentate temperature could rise due to the friction inside the membrane module, a heat exchanger was placed before its return to the feed vessel in order to support the cryogenic system of the reservoir to assure that the feed temperature is kept at $20 \stackrel{\circ}{ } \mathrm{C}$ and to reduce power consumption.

The experiments were performed by using a flat sheet crossflow module with a single channel of length $L=110 \mathrm{~mm}$, width $W=60 \mathrm{~mm}$ and height $H=0.5 \mathrm{~mm}$. This cell's dimensions provide a membrane active area $A_{m}=6.6 \cdot 10^{-3} \mathrm{~m}^{2}$, a transversal membrane channel area $A_{T}=3 \cdot 10^{-5} \mathrm{~m}^{2}$ and a transversal perimeter $P_{T}=121 \cdot 10^{-3} \mathrm{~m}$, so the hydraulic diameter of the channel $d_{h}=9.917 \cdot 10^{-4} \mathrm{~m}$.

\subsubsection{Synthetic Solution and Must}

Firstly, a synthetic solution was filtered. This solution contained the main low molecular weight compounds present in natural red must and it was isomolecular of glucose and fructose. Its $\mathrm{pH}$ was set to be similar to that of a natural must: $\mathrm{pH}=3.51$ and its composition is shown in Table $3.2[33,34]$. The conductivity, measured at $25^{\circ} \mathrm{C}$ was $2.37 \mathrm{mS} / \mathrm{cm}$.

Table 3.2. Composition of the synthetic solution filtered

\begin{tabular}{|c|c|c|c|c|c|c|c|}
\hline Substance & $\begin{array}{c}\text { Total Sugar }^{a} \\
(g / L)\end{array}$ & $\begin{array}{l}\mathrm{MH}_{2}{ }^{\mathrm{a}} \\
(\mathrm{g} / \mathrm{L})\end{array}$ & $\begin{array}{l}\mathrm{TH}_{2}{ }^{\mathrm{a}} \\
(\mathrm{g} / \mathrm{L})\end{array}$ & $\begin{array}{c}\mathrm{K}^{\mathrm{a}} \\
(\mathrm{mg} / \mathrm{L})\end{array}$ & $\begin{array}{l}\mathrm{Na}^{\mathrm{b}} \\
(\mathrm{g} / \mathrm{L})\end{array}$ & $\begin{array}{l}\mathrm{Ca}^{b} \\
(\mathrm{~g} / \mathrm{L})\end{array}$ & $\begin{array}{l}\mathrm{Mg}^{\mathrm{b}} \\
(\mathrm{g} / \mathrm{L})\end{array}$ \\
\hline Concentration & 204.50 & 2.36 & 6.37 & 1550 & 0.11 & 0.27 & 0.18 \\
\hline
\end{tabular}

Afterwards, the filtration of a commercial red must was performed. Normally, the content of sugars, salts and acidity (mainly tartaric acid) of natural musts is reduced for its commercialization in order to satisfy consumers demands (lower sugar and no sodium content) and to avoid undesirable precipitations mainly due to the formation of tartaric aggregates. Besides, natural must is stabilized by adding citric acid in order to avoid spontaneous fermentations. Therefore the original contents of glucose, fructose, potassium, malic and tartaric acid were analyzed, as showed in Table 3.3 and then, if necessary, they were modified to approach those of the natural must and so the synthetic solution. The sodium, calcium and magnesium contents were adjusted in the must until a pH equal 3.51 using solutions of $\mathrm{NaOH}, \mathrm{Ca}(\mathrm{OH})_{2}, \mathrm{Mg}(\mathrm{OH})_{2}$, in adequate quantities in order to keep the proportions shown in Table 3.2. The conductivity of the 
resulting commercial must was $2.55 \mathrm{mS} / \mathrm{cm}$. Since the color index of the commercial must used was similar to other natural red musts used in previous works [16], it was assumed that the concentration of the high molecular weight compounds in this work was similar, since a significant portion of these compounds contribute to the color. The addition of sugar and other additional compounds does not change the color index, which allowed assuming that this addition does not change the balance of the high molecular weight substances.

Table 3.3. Original composition of the natural red must

\begin{tabular}{lcccccc}
\hline Substance & $\begin{array}{c}\text { Glucose } \\
(\mathbf{g} / \mathbf{L})\end{array}$ & $\begin{array}{c}\text { Fructos } \\
\mathbf{e}(\mathbf{g} / \mathbf{L})\end{array}$ & $\begin{array}{c}\mathbf{M H}_{2}{ }^{a} \\
(\mathbf{g} / \mathbf{L})\end{array}$ & $\begin{array}{c}\mathrm{TH}_{2}{ }^{a} \\
(\mathbf{g} / \mathbf{L})\end{array}$ & $\begin{array}{c}\mathbf{K} \\
(\mathbf{m g} / \mathbf{L})\end{array}$ & $\begin{array}{c}\mathrm{Na}^{a} \\
(\mathbf{g} / \mathbf{L})\end{array}$ \\
\hline Concentration & 69.56 & 68.29 & 2.31 & 1.44 & 1570 & 0.0 \\
\hline $\begin{array}{l}{ }^{a} \text { Provided by manufacturer on the must label } \\
\mathrm{MH}_{2}=\text { malic acid; } \mathrm{TH}_{2} \text { = tartaric acid; } \mathrm{K}=\text { potassium; } \mathrm{Na}=\text { sodium }\end{array}$ & &
\end{tabular}

\subsubsection{Procedure}

In order to avoid any irreversible change during operation, the membrane was pressurized at the highest pressure to be used for a sufficient period of time. Here, the NF270 was pressurized filtering Milli $-\mathrm{Q}$ water at $3510^{5} \mathrm{~Pa}$ with a recirculation flow of $5 \mathrm{~L} / \mathrm{min}$ during one hour. After that, water permeability was measured. This measurement was repeated before and after all filtration and cleaning steps.

The operating conditions for both filtrations (synthetic solution and commercial must) were: a feed temperature of $20^{\circ} \mathrm{C}$; an applied pressure of $35 \cdot 10^{5} \mathrm{~Pa}$; a recirculation flow of $5 \mathrm{~L} / \mathrm{min}$, which supposes a feed tangential velocity on the membrane surface of $2.78 \mathrm{~m} / \mathrm{s}$.

The permeate flux was determined by timing and measuring the volume collected in a test tube during the filtration, first every 15 minutes and then, when the permeate flux reached less variable values, every 45 minutes. Samples of permeate, retentate and accumulated permeate were taken in order to determine their glucose and fructose content by liquid chromatography. Filtrations were performed until the permeate flux decreased to a more or less constant value for a reasonable period of time.

The volumes filtered where of the order of $2500 \mathrm{~mL}$ of both, synthetic solution and red must. The nanofiltration processes were performed by duplicate and similar results were obtained for both experimental determinations. 


\subsubsection{Cleaning}

Even though the membrane flat sheets were not re - used after each filtration process, both were cleaned in order to determine the permanent water permeability loss caused individually by the LMW and the HMW.

After the filtration of the solution, the membrane was rinsed with water, under the same operating conditions of temperature, pressure and recirculation flow, during one hour. Then it was rinsed with Milli-Q water and the hydraulic permeability was determined.

In the case of must filtration, an important reduction in permeability was observed due to the fouling of the membrane. That is why the following cleaning procedure was performed, in this case:

1) Rinsing with water under the operation conditions during one hour.

2) Rinsing with Milli-Q water and permeability measure.

3) After this, a solution of $0.1 \%$ of sodium dodecyl sulfate was used, to clean the membrane module, according to the literature [35].This reduces the surface tension of the liquid, making easier to remove the dirt. According to the membrane manufacturer's cleaning conditions specifications, $\mathrm{pH}$ was adjusted to 9 with $\mathrm{NaOH}$ and, if necessary, $\mathrm{HCl}$. This cleaning step was performed during one hour under the operation conditions.

4) Rinsing with water during one hour at the operation conditions.

5) Once more, rinsing with Milli-Q water and permeability measurement.

6) Storage in phenol solution, with $\mathrm{pH}=6$.

\subsubsection{Analytical Methods}

\section{Glucose and Fructose determination}

Identification and quantification of the concentration of glucose and fructose was achieved by using an HPLC LC-9A apparatus from Shimadzu, with a Refractive Index detector Shimadzu RID 6A, a Rheodyne injector with a $20 \mu \mathrm{L}$ loop and the software Class-VP. Separation was carried out isocratically in $100 \%$ deionized water at a flow rate of $0.5 \mathrm{~mL} / \mathrm{min}$ at $85^{\circ} \mathrm{C}$ using a SUPELCO ion exchange guard column and a Supelcogel $\mathrm{Pb}$ column. In order to improve the resolution and precision, the samples were diluted 1:10 (V/V) with the mobile phase and then filtered through a $0.2 \mu \mathrm{m}$ nylon membrane before the direct injection. 


\section{L- malic acid determination}

The quantification of the malic acid content present in the commercial must was performed according to the enzymatic method described by the OIV [36]. For this purpose the Novakit "L-malic acid" enzymatic kit was used. The NADH formation during the enzymatic reaction was determined by measuring the absorbance at a wavelength of 340nm with an UV-vis Shimadzu UV160A spectrophotometer.

\section{L- tartaric acid determination}

The tartaric acid content of the commercial must was determined by using the colorimetric technique according to the Rebelein modified method [37]. For the absorbance measurements an UV-vis Shimadzu UV160A spectrophotometer at a wavelength of $530 \mathrm{~nm}$ was used.

\section{Potassium determination}

Potassium content of the commercial must was determined by measuring the potassium ion activity according to a potentiometric method [38]. For this purpose a potassium selective CRISON 9661 and a reference CRISON 5044 electrodes were used. The potential measurements were determined with a multimeter YOKOGAWA 7562.

\subsection{Results and Discussion}

\subsubsection{Nanofiltration Processes}

As mentioned, water permeability $\left(L_{p}\right)$ was measured, before and after every filtration or cleaning process as the slope of the $J_{v}$ versus $\Delta \mathrm{P}$ plot with Milli-Q water. From $L_{p}$ data, the initial and final membrane resistances, $R_{m}(t)$, were calculated according to Eqs. (1) and (2) where $R_{f}(t)=0$ and $\Delta \pi=0$. These measurements determine the loss of membrane permeability or the increase of resistance, due to fouling during filtration and the recovery after the cleaning process. Results are presented in Table 3.4. After synthetic solution filtration and membrane rinse, water permeability was slightly reduced (there is a final reduction of $13 \%$ from the original permeability) which is attributed to the irreversible fouling of the membrane due to the adsorption of low molecular weight substances on the surface or inside the pores. After must nanofiltration and membrane rinsing, water permeability was reduced by $45 \%$ and it can be noticed that there is a slight recovery after the cleaning process, without reaching the original value of the brand new membrane (final reduction of $37 \%$ ). This 
means that the filtration of must causes a higher irreversible fouling (permeability permanent loss) due to the presence of high molecular weight compounds.

Table 3.4. Hydraulic permeability and membrane resistance of the NF270, both initially and after filtration and cleaning stages

\begin{tabular}{ccccc}
\hline Process & $\begin{array}{c}\text { Before } \\
\text { filtration }\end{array}$ & $\begin{array}{c}\text { After synthetic } \\
\text { solution rinse }\end{array}$ & $\begin{array}{c}\text { After red } \\
\text { must rinse }\end{array}$ & $\begin{array}{c}\text { After must } \\
\text { cleaning with SDS }\end{array}$ \\
\hline $\begin{array}{c}\text { Water } \\
\text { Permeability } \mathrm{L}_{\mathrm{p}} \\
\left(10^{-11} \mathrm{~m} / \mathrm{Pa} \cdot \mathbf{s}\right)\end{array}$ & 3.84 & 3.34 & 2.10 & 2.45 \\
\hline $\begin{array}{c}\text { Membrane } \\
\text { Resistance } \\
\mathbf{R}_{\mathrm{m}}\left(10^{13} \mathrm{~m}^{-1}\right)\end{array}$ & 2.60 & 2.98 & 4.75 & 4.07 \\
\hline
\end{tabular}

Figure $3.2 \mathrm{a}$ and $\mathrm{b}$ present the kinetics of permeate flux and total volume flow respectively of both, the must and synthetic solution filtrations. As shown (see Figure 3.2a), there is a remarkable decrease of the flow during the first period until reaching a more or less flat plateau. It is worth noting that the synthetic solution permeates approximately 8 times more volume than must while flux is around 10 times higher.
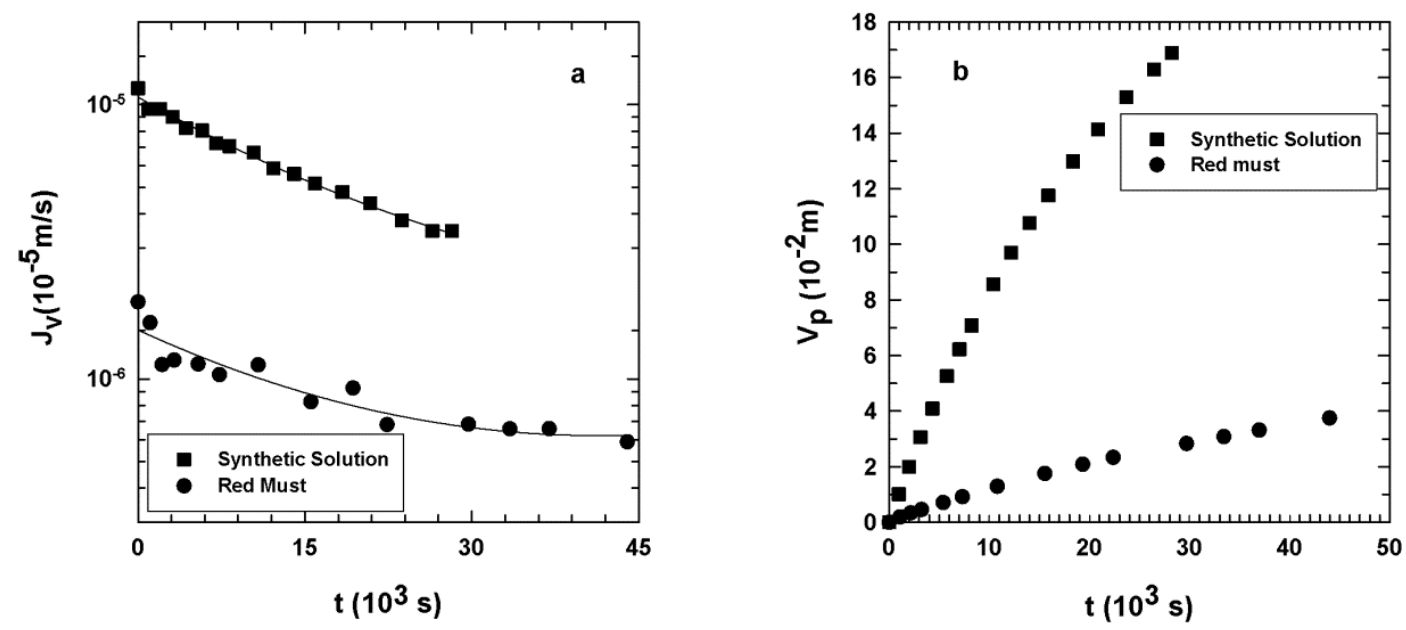

Figure 3.2. Permeate flux (a) and total volume (b) permeated through the membrane per unit area versus filtration time

This decreasing could be expected since there are several factors that promote the corresponding flux decay:

1. The osmotic pressure increase due to the increment of the concentration of small molecules, mainly glucose and fructose, in the retentate, $\left(C_{o, i}\right)$ and consequently on the membrane surface $\left(C_{m, i}\right)$. 
2. Increase of the viscosity of the fluid that goes through the membrane pores.

3. Fouling due to the reversible or irreversible adhesion of the molecules on the membrane surface or inside the pores which reduces their diameter and so the flux too.

4. Formation and thickening of a gel layer (cake) on the membrane surface due to the rise of the concentration of high molecular weight species and colloids on the membrane surface.

In the case of the synthetic solution filtration only the three first factors must be taken into account, since there are no high molecular weight compounds. Therefore in Eq. (3) the resistance $R_{\mathrm{fH} M W}=0$. Of course, for the must filtration none of the four factors can be neglected.

All in all, there are three main differences between both filtrations. First, the initial value of the must permeate flux is practically ten times lower than the corresponding for the solution $\left(1.91 \cdot 10^{-6}\right.$ and $1.15 \cdot 10^{-5} \mathrm{~m} / \mathrm{s}$ respectively). Second, the must could be filtered for a longer period of time than the solution, since there was no significant increment on the osmotic pressure and/or viscosity of the retentate. In the case of the synthetic solution these factors made that the filtration had to be stopped. However, a minimum and almost constant permeate flux was reached at half the total filtration time, as shown in Figure 3.2a. The third important difference is the accumulated volume of permeate, that for the must was less than for the solution, although the period of filtration was longer.

These permeate flux differences were expected, because of the presence of high molecular weight compounds in must. In this case the four mentioned factors have to be taken into account, so the formation and thickening of the gel layer (cake) on the membrane surface generates another resistance to permeate flux, $R_{\mathrm{f}} H M w$, which has to be considered in Eq. (3).

It is worth mentioning that from the first instants of the must filtration a reduction of color in the permeate samples was observed which increased along the process. This means that the high molecular weight substances responsible for the color (polyphenolic compounds mainly anthocyanins) are retained by the membrane and during the process the accumulation of all high molecular weight compounds forms a pseudo membrane which increases the retention of anthocyanins and other compounds. These agrees with the work of García- Martin et al. [16], where a different nanofiltration membrane with similar MWCO was used and their results showed than high molecular weight compounds are almost completely retained. 


\subsubsection{Fouling Analysis}

A description of the flux decline observed in Figures $3.2 \mathrm{a}$ and $3.2 \mathrm{~b}$ can be done in terms of the fouling mechanisms summarized in Eq. (13). In nanofiltration, usually appears first a pore blocking mechanism eventually followed by the formation of a cake.

Eq. (17), predicted by the intermediate blocking model is plotted in Figure 3.3a, showing that such a mechanism seems to be compatible with data corresponding to the filtration of the synthetic solution and with the first steps of must filtration (a second step of intermediate blocking with a different kinetics should be difficult to justify although it could be fitted to the resulting plot).

Eq. (18) corresponding to the "cake formation" mechanism is plotted in Figure $3.3 \mathrm{~b}$ where it is clearly seen that this mechanism could be followed with the synthetic solution filtration (like the "Intermediate Blocking" model) and with the second step of the nanofiltration of must.
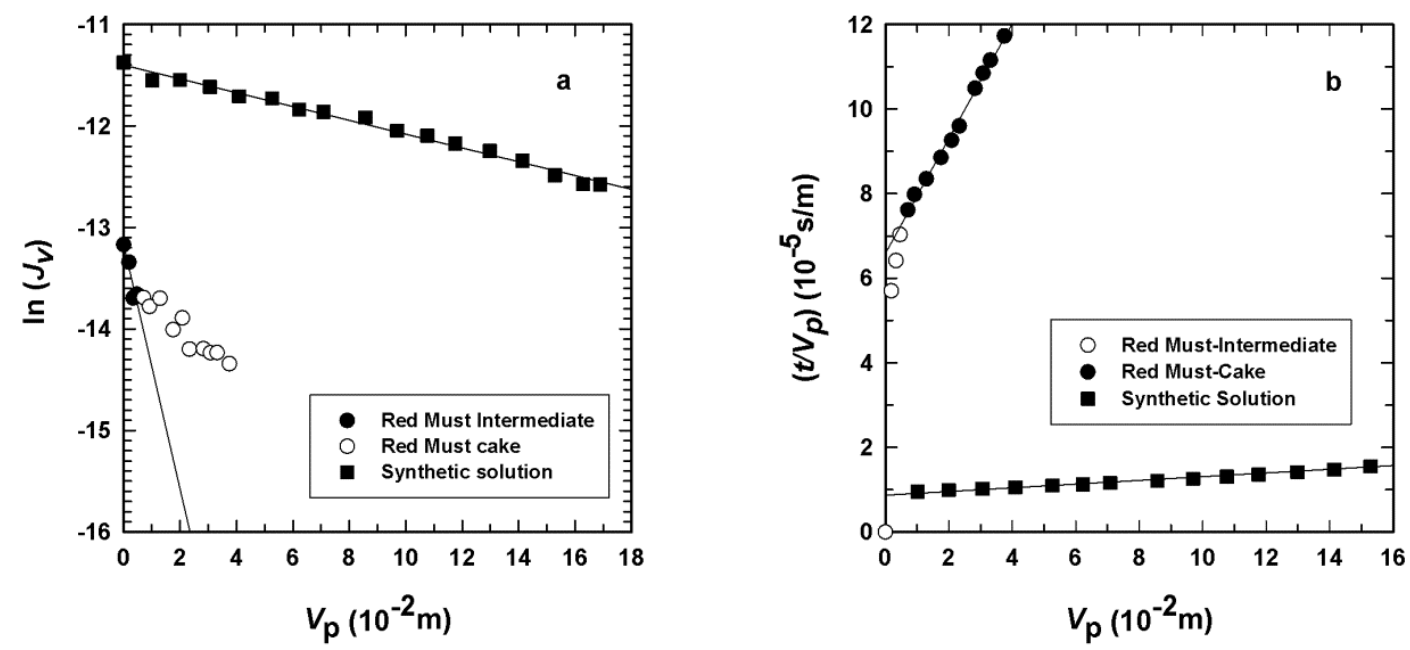

Figure 3.3 $\mathrm{Ln}\left(J_{v}\right)$ versus permeate volume fitted to the intermediate blocking (a) and $t / \mathrm{V}_{\mathrm{p}}$ versus $V_{p}$ fitted to the cake filtration model (b).

For the synthetic solution, because of the exclusive presence of low molecular weight species, both the "intermediate" and the "cake" mechanisms could occur. Although if the pore-to-size relation is taken into account and since the low predictable adsorption of sugars on the membrane seems improbable [39], it seems that an "Intermediate Blocking" should be more feasible. Moreover in Figure 3.3a it is clearly seen that the slope is much higher for the must $\left(k_{=}=120 \pm 30 \mathrm{~m}^{-1}\right)$ than for the synthetic solution $\left(k_{F}=6.80 \pm 0.19 \mathrm{~m}^{-1}\right)$. These agrees with several results reported by Listiarini et al. $[40,41]$ for the study of fouling of nanofiltration membranes where minimal or not pore blocking of the nanofiltration membrane was detected during the filtration of 
systems containing high molecular weight substances (organic matter) such as sodium alginate and humic acid and different ions (calcium and/or alum) .

For the must it seems clear that a change in kinetics appear probably corresponding to an initial pore blocking followed by a formation of a cake when the high molecular weight molecules start to be deposited onto the first arrived ones. The fitting of Eq. (18) leads to the cake formation the following kinetic constants: $\left(k_{c}=3.02\right.$ $\pm 0.08) \cdot 10^{16} \mathrm{~s} / \mathrm{m}^{6}$ for the red must and $\left(k_{c}=9.7 \pm 0.3\right) \cdot 10^{14} \mathrm{~s} / \mathrm{m}^{6}$ for the synthetic solution. According to these values, the presence of high molecular weight compounds accelerates the fouling mechanism in red must nanofiltration by approximately 30 times.

According to Schippers and Verdouw [32] the plot of Eq. (18) can be divided in three regions that differentiate the fouling mechanisms over the filtration period: (I) Pore blocking region, (II) cake formation without compression and (III) cake formation with compression. In our case, as shown in Figure 3.3b, the nanofiltration of must showed: first a pore blocking process $(\mathrm{I})$ then, during a longer period, a cake formation phenomenon (II). No appreciable cake compression (region (III)) has been noticed.

\subsubsection{Evolution of concentration of sugars and membrane efficiency}

The time evolution of the content of sugars in both permeate and retentate for both filtrations is shown in Figure 3.4. A clearly linear, and quite similar, increase of concentrations of both glucose and fructose can be noticed for the synthetic solution retentate. In the case of the synthetic solution permeate at the beginning there is a slight decrease of concentration followed by a clear increase. This phenomenon is attributed to the increase of concentration of glucose and fructose on the retentate side that finally cross the membrane. The accumulated permeate gave $77 \%$ lower sugars concentration and the retentate $30 \%$ higher concentration than the initial feed solution.

On the contrary, in the case of the must permeate (see Figure 3.4), there is a progressive decrease of the concentration of total sugars until reaching very low values. This difference is mainly attributed to the formation of a gel layer on the membrane surface that acts as a pseudo-membrane which lowers even more the passage of sugars through the membrane by changing both: permeability and selectivity of the overall membrane. The final sugars concentration of must permeate was $67 \%$ lower than the initial feed. The must retentate concentration also presented a lineal increase during the filtration, However it's important to remember that a small volume of must permeate was obtained, therefore the increase in sugars concentration was only $4 \%$ of the initial feed must. Figure 3.4 shows that the synthetic solution is 
initially more diluted than the values presented in Table 3.2, but the desired values are reached throughout the process. The experiment was carried out in this way because it allowed analyzing the trend of osmotic pressure without excessively increasing the experimental operation time.

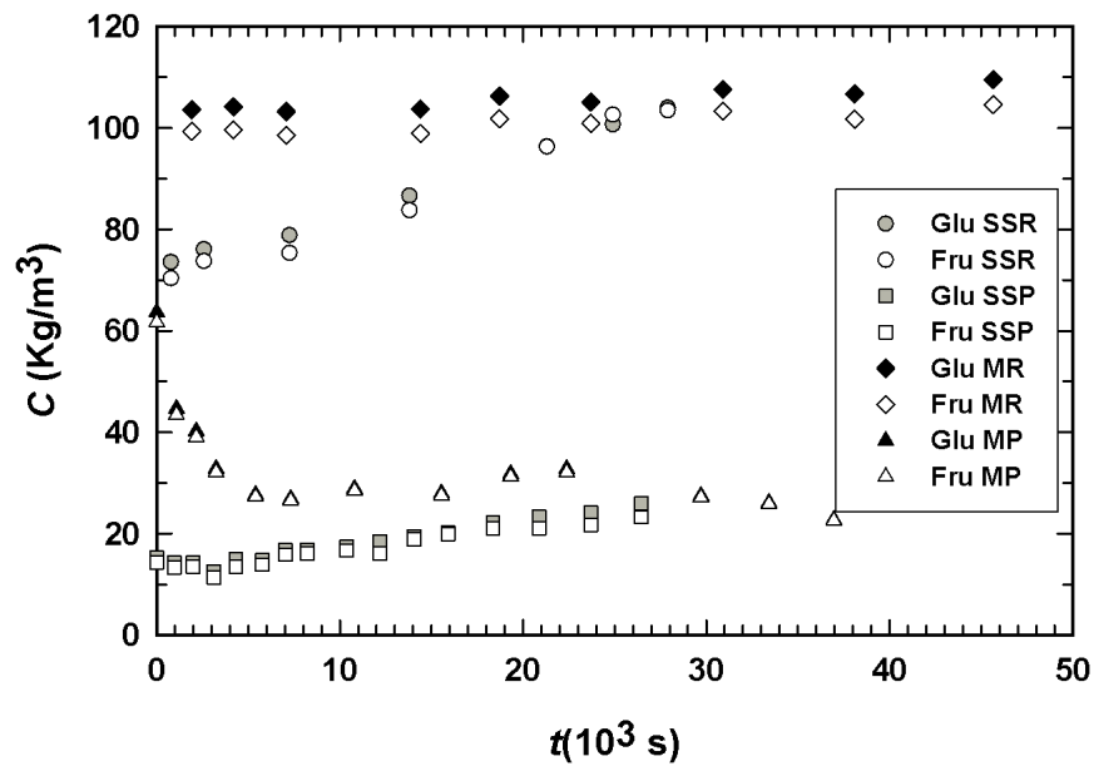

Figure 3.4. Time evolution of the Glucose (Glu) and Fructose (Fru) content of the synthetic solution retentate (SSR), synthetic solution permeate (SSP), must retentate (MR) and must permeate (MP).

As mentioned, the sugars concentration measurements for the permeate and retentate allow the determination of the membrane efficiency by calculating the time evolution of the true retention of each sugar, $R_{i}$, according to Eq.(12).

For the synthetic solution as well as for must, the mass transfer coefficient of each sugar $\left(K_{m, i}\right)$ was calculated by the dimensionless numbers correlation given in Eq. (6). When there is a turbulent flow and when $430<\mathrm{Sc}<10^{5}$, Eq. (6) can be written as the Harriot - Hamilton equation [42]:

$S h=0.0096 \cdot R e^{0.91} \cdot S c^{0.35}$

The density values used for the synthetic solution were the mean density of glucose and fructose solutions as a function of their concentration (mol / L) at $20{ }^{\circ} \mathrm{C}$ obtained from literature [43]. For red must, the correlation between density and its sugar content ('Brix) was extracted from literature too [44].

For the viscosity increase during the synthetic solution filtration, the mean viscosity value between glucose and fructose solutions was used as a function of their concentration at $20 \stackrel{\circ}{\circ}$ obtained from the literature [43]. In the case of red must the viscosity values used were obtained by a correlation as a function of the concentration 
(Brix) according to the procedure proposed by Zuritz et al. [45], in which the Arrhenius equation is used according to:

$\eta=\eta_{0} \cdot e^{\left(E_{a} / R T\right)}$

here $\eta$ is de viscosity in $\mathrm{mPa} \cdot \mathrm{s} ; \eta_{0}$ is a constant in $\mathrm{mPa} \cdot \mathrm{s} ; E_{a}$ is the activation energy; $R$ is the ideal gas constant and $T$ the absolute temperature. The experimental $\eta_{0}$ values of Zuritz et al, were logarithmically correlated as a function of ${ }^{\circ}$ Brix of must with a second degree polynomial equation. In order to obtain the $E_{a} / R$ values as a function of -Brix, the second degree polynomial equation proposed by Zuritz et al. was used.

Since the variation of the diffusion coefficients, $D_{i}$, with concentration is low, the values at infinite dilution for glucose and fructose were used: $6.75 \cdot 10^{-10}$ and $7.002 \cdot 10^{-10}$ $\mathrm{m}^{2} / \mathrm{s}$ respectively [46].

The values of $K_{m, i}$ were corrected by using Eq. (9) and $C_{m, i}$ was obtained for each $J_{v}$ according the Thin Film Theory equation (Eq. 5).

Figure 3.5 shows the results obtained for the retention of sugars in both filtrations. It can be noted that, mainly at the beginning, the retention of sugars in must is lower than in the synthetic solution. Furthermore, it can be seen that the sugars retention in the synthetic solution remains practically constant, while in must it increases remarkably in a first step. These differences are due to the presence of other substances that, as commented, change the permeability and selectivity properties of the membrane.

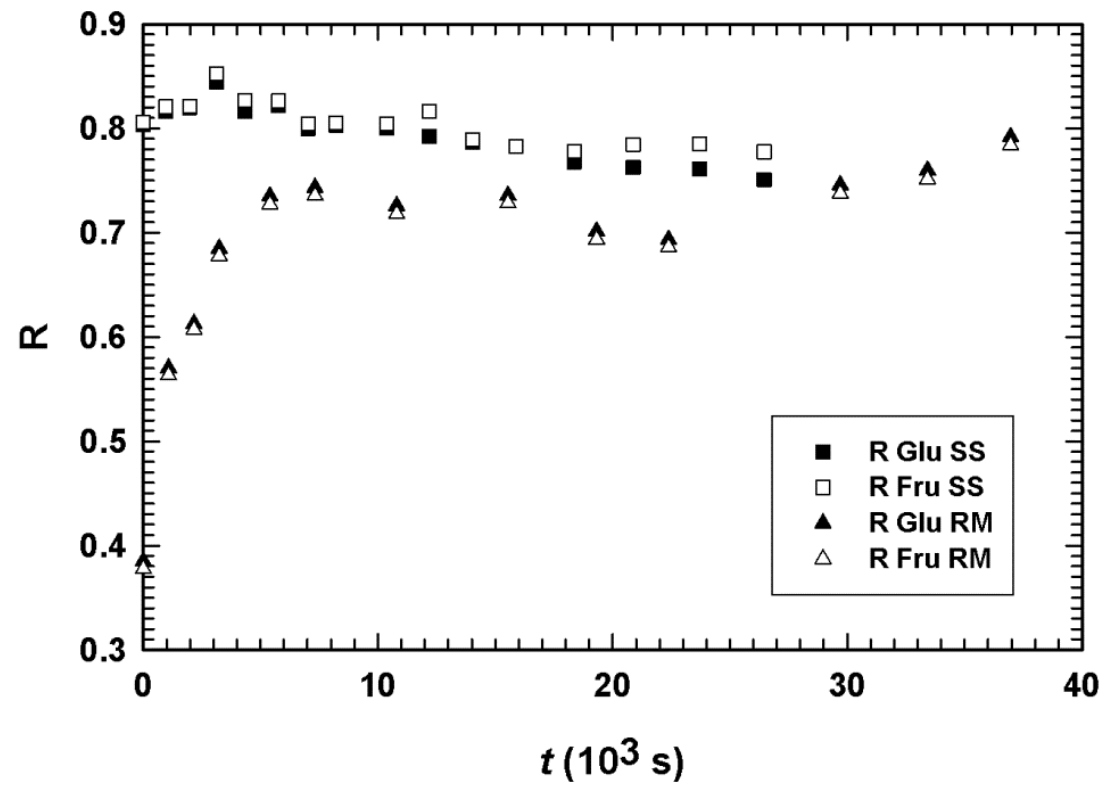

Figure 3.5. Time evolution of the True Retention (R) of Glucose and Fructose in the synthetic solution (SS) and red must (RM) nanofiltration 
As shown in Figures 3.4 and 3.5, the filtration of neither the synthetic solution nor the red must caused a de-compensation between glucose and fructose. This means that even though the total sugar content of the feed varies, the original relation of glucose and fructose is not modified by the process. For a proper fermentation, it is important that the membrane process does not alter this natural grape must property.

\subsubsection{Determination of the resistances to the permeate flux}

First, the values of $R_{f} L M W$ for the synthetic solution permeate flux where calculated by according to Eqs. (1) and (2) when $R_{f H M W}=0$.

The osmotic pressure increase in the synthetic solution and in red must, was determined using Eq. (4), taking into account only the contribution of glucose and fructose. This was considered appropriate since the concentration of charged low molecular weight substances (potassium, calcium, sodium and magnesium) is quite similar on both sides of the membrane. Besides, the organic acids concentration is much lower than that of sugars so their contribution to the osmotic pressure can be considered negligible compared to those of glucose and fructose.
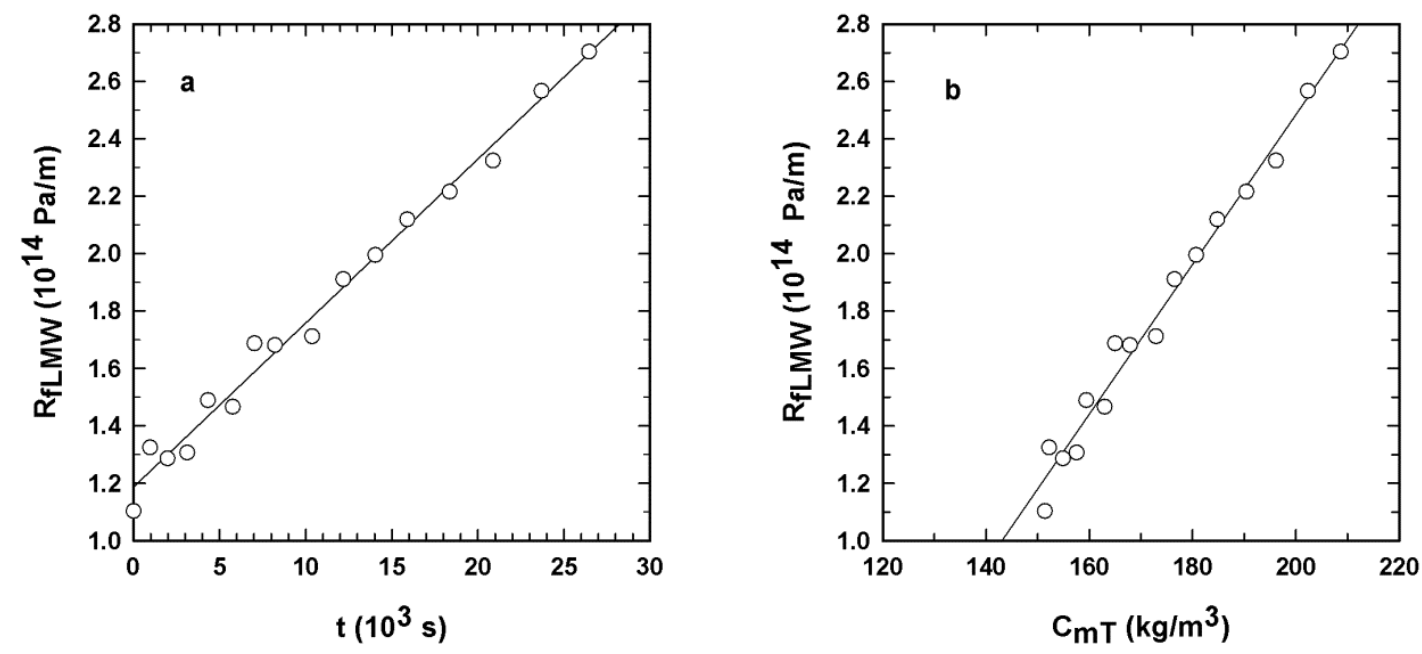

Figure 3.6. Evolution of $R_{f L M w}$ as a function of filtration time (a) and as a function of sugars concentration in the membrane surface $\left(\mathrm{C}_{\mathrm{mT}}\right)(\mathrm{b})$ for the synthetic solution filtration

Figure 3.6a represents the kinetics of $R_{f L M W}$ during the synthetic solution filtration. The correlation between this resistance and the total sugars concentration (glucose and fructose) on the membrane surface, $C_{m T}$ is shown in Figure $3.6 \mathrm{~b}$. It can be noted that there is a progressive increase in this resistance during the filtration (Figure 3.6a) and according to Figure 3.6b, there is parallel increment of the sugars concentration on the membrane surface. Besides, it can be observed that the 
correlation between $R_{f L M W}$ and $C_{m, T}$ is practically lineal, so it can be assumed that the accumulation of sugars on the membrane surface is proportional to the concentration increase.

The values of $R_{f L M W}$ for the red must filtration were determined by the calculation of $C_{m T}$ and the use of the correlation between $R_{f L M W}$ and $C_{m T}$ obtained for the synthetic solution. Figure 3.7 a shows the variation of $R_{f L M W}$ with time along the process of must filtration. As can be seen, there is not a significant increase of this resistance as in the case of the solution. This difference is due to the lower sugars concentration increment in the retained must.Finally, replacing the values $R_{f L M W}$ obtained in Eqs. (1) and (2), the resistance $R_{f H M W}$ during the red must filtration could be determined. Figure $3.7 \mathrm{~b}$ shows the time evolution of the resistances to the permeate flux during must filtration: $R_{f L M W}$ and $R_{f H M w}$ and the sum of them, $R_{f .}$. Here, it can be noted how, in the same period of analysis, $R_{f L M W}$ remains practically constant in comparison to the $R_{f H M W}$ which increases progressively until reaching a maximum, beyond which there is a progressive slight decrease.
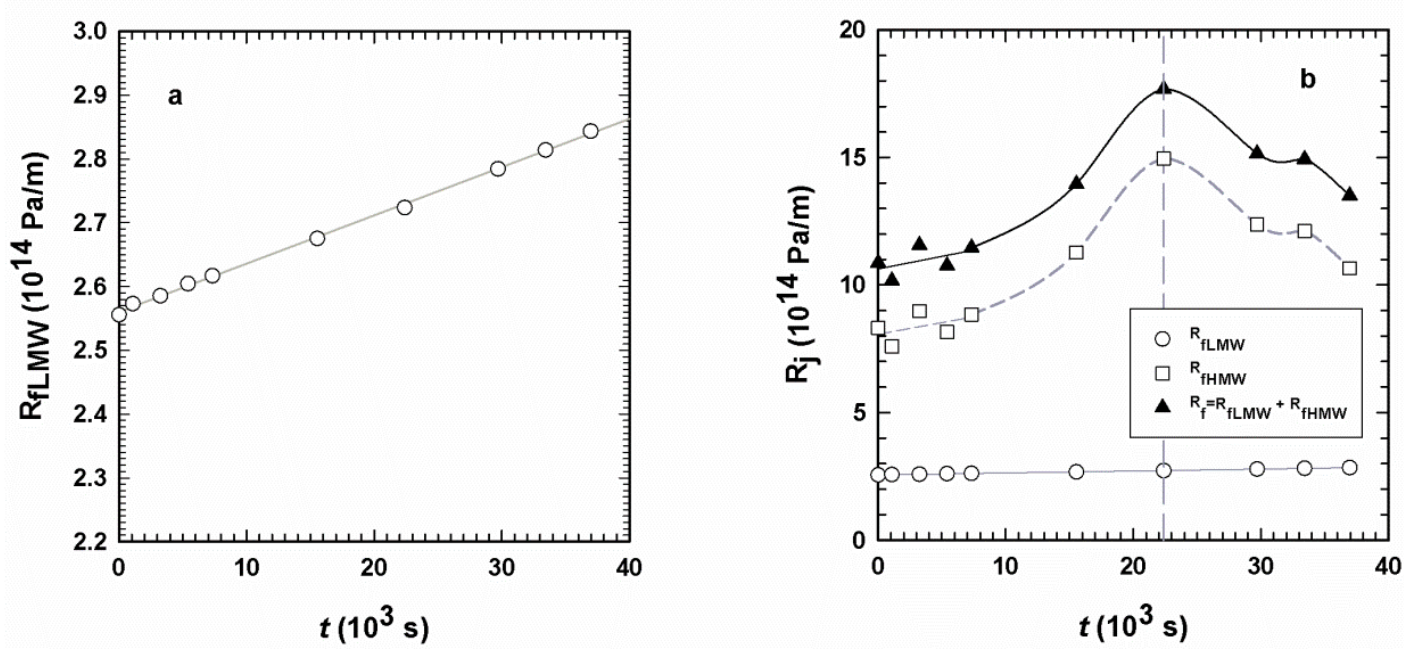

Figure 3.7 Time evolution during must filtration of the resistance due to fouling by low molecular weight compounds: $\mathrm{R}_{\mathrm{fLMW}}$ (a) and comparison of the individual resistances due to fouling caused by all compounds present in red must (b)

According to the studies of Foley et al. [47] a reduction in the (specific) cake resistance can be caused in compressible cakes due to a reduction in the pressure drop across the filter cake. This phenomenon is possible considering that the overall pressure drop (applied transmembrane pressure $\Delta p$ ) at any time is the sum of pressure drops over membrane, $\Delta p_{m}$, cake, $\Delta p_{c}$ and osmotic pressure, $\Delta \pi$. It has to be taken into account that $R_{m}$ may vary with the pressure drop $\Delta p_{m}$, due to the reversible or irreversible adhesion of the molecules on the membrane surface or inside the pores. But this resistance variation is important only during the first stages of filtration. During 
the important stage of the filtration, when the cake is of appreciable thickness $\Delta p_{m}$ is small in comparison with $\Delta p_{c}$. So, a reduction in $\Delta p_{c}$ (and so in $\mathrm{R}_{\mathrm{fHMW}}$ ) may occur due to a remarkable osmotic pressure increase which leads to a decay of the effective pressure across the cake. This suggested that the cake formed may be slightly compressible and its compression begins when the maximum $R_{f H M W}$ is reached. After this, an osmotic pressure increase should take place since sugars may be more retained by the more compacted gel layer.

In order to analyze this, the osmotic pressure during red must nanofiltration was plotted in Figure 3.8. It can be appreciated that exactly when the maximum of $R_{f H M W}$ is reached, the osmotic pressure starts, in effect, to increase, promoting a cake pressure drop as mentioned.

Furthermore, when osmotic pressure starts to increase, sugars begin to be more retained by the membrane system as can be noticed in Figures 3.3 and 3.4. So, as already mentioned, the sugars retention increase can be attributed to the formation of a gel layer on the membrane surface but a compression of it may be the cause of the significant retention increase (and osmotic pressure increase) at the end of the filtration period.

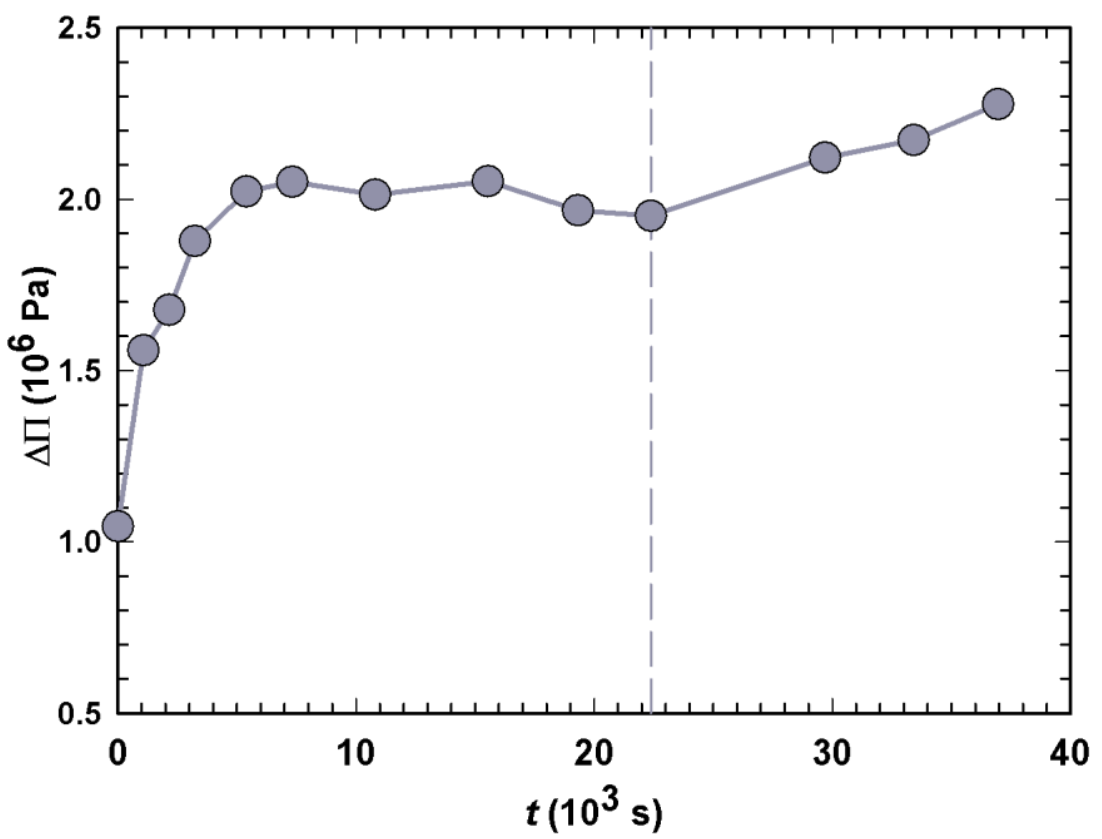

Figure 3.8 Time evolution of the osmotic pressure difference $(\Delta \Pi)$ due to sugars during red must nanofiltration

After the comparison of both filtrations it could be said that the presence of high molecular weight compounds, which are characteristic of red must, enhances the gel layer formation (which plays the role of a pseudo-membrane that changes both: the 
permeability and the selectivity properties) which induces different phenomena such as:

1) Lower values of permeate flux from the beginning of the process.

2) Progressively lower sugar concentration in the permeate.

3) Less water permeability recovered after the cleaning process, which means that these compounds have a higher irreversible adsorption on the membrane surface or inside the pores.

4) Lower permeate volume recovery.

It is worth considering that the last three facts mentioned above may be due to the manufacturing characteristics (polymer and pore size) of the nanofiltration membrane used, NF270. These membrane characteristics can cause a fast formation and thickening of the gel layer on the active layer of the membrane, which leads to a fast decrease of the permeate flux that afterwards slows down the process very steeply. Due to this, the permeate flux reached a minimum in such a short time that a higher permeated volume would need an excessive operation time.

\subsection{Conclusions}

The rapid formation and thickening of the gel layer on the membrane surface, during red must filtration caused extreme conditions of analysis: small increase in the concentration of sugars in the retentate and rapid decline in $J_{v}$, obtaining a small volume of permeate. The analytical method proposed seems adequate, since it enabled the individual study of the influence of the LMW and HMW on the permeate flux decay, even under these very fast and strong irreversible fouling.

According to the methodology of analysis proposed, the following main conclusions can be raised:

1) Since the concentration of sugars in the retentate did not cause a significant increase in $R_{f L M W}$, the primary responsible of the permeate flux decline in the nanofiltration of red must is the formation and thickening of the gel layer on the membrane NF270 caused by the high molecular weight substances. Therefore, low molecular weight compounds influence on the permeate flux decrease is mainly represented by the osmotic pressure increase.

2) The presence of HMW increases the membrane fouling mechanism by around 30 times. 
3) The decay of $R_{\text {fHMw }}$ at the end of the red must filtration suggests that the cake formed may be compressible causing an osmotic pressure increase which reduces the effective pressure drop across the cake and so its resistance to $\mathrm{J}_{\mathrm{v}}$.

4) The formation of the gel layer on the membrane surface changes the selectivity to sugars, but the compression of this cake increases the retention even more.

Finally, the optimization of the process will consist on the selection of a nanofiltration membrane with an appropriate sugars retention (pore size), about $50 \%$, and a low affinity to high molecular weight substances (manufacturing polymer) in order to maintain substantially unaltered its retention characteristics due to the accumulation of these substances on the membrane surface.

\subsection{Acknowledgements}

Authors would like to thank the "Ministerio de Ciencia e Innovación (MCINN)" for the financial support of this work within the frame of the "Plan Nacional de I+D+I" through the research project CTQ2009-07666.

C. Salgado wants to thank the Spanish Ministry of Education for the grant they gave to her within the frame of the "Plan Nacional de Investigación Científica, Desarrollo e Innovación Tecnológica 2008-2011" (FPU grant: AP2010-5769) to complete her PhD.

Authors acknowledge Dow-Filmtec for the free supply of membrane flatsheet samples to conduct this research. 


\subsection{Nomenclature}

Roman

a

$A_{m}$

$A_{T}$

$C_{0, i}$

$C_{m, i}$

$C_{p, i}$

$d_{h}$

$D_{i}$

$E_{a}$

$\mathrm{R}$

T

HMW

$J_{v}$

$J_{v, 0}$

k

$k_{c}$

$k_{i}$

$k_{s}$

$K_{m, i}$

$K_{m, i}^{*}$

LMW

$L_{p}$

$P_{T}$

Re

$R_{f}$

$R_{f H M W}$

$R_{f j}$

$R_{f L M W}$

$R_{i}$

$R_{m}$

$R_{\text {Sys }}$

Sc cake compressibility constant

Membrane active area $\left(\mathrm{m}^{2}\right)$

Transversal membrane channel area $\left(\mathrm{m}^{2}\right)$

Feed concentration of each component $\left(\mathrm{kg} \mathrm{m}^{-3}\right)$

Concentration of each component on the membrane active layer $\left(\mathrm{kg} \mathrm{m}^{-3}\right)$

Permeate concentration of each component $\left(\mathrm{kg} \mathrm{m}^{-3}\right)$

Hydraulic diameter of the membrane channel $(\mathrm{m})$

Diffusion coefficient of each component $\left(\mathrm{m}^{2} \mathrm{~s}^{-1}\right)$

Activation energy $\left(\mathrm{kcal} \mathrm{mol}^{-1}\right)$

ideal gas constant $\left(1.987 \cdot 10^{-3} \mathrm{kcal} \mathrm{mol}^{-1} \mathrm{~K}^{-1}\right)$

Absolute temperature $(\mathrm{K})$

High molecular weight compounds

Permeate flux per unit of area through the membrane $\left(\mathrm{m}^{3} \mathrm{~m}^{-2} \mathrm{~s}^{-1}\right)$

Permeate flux per unit of area through the membrane at time $t=0$ $\left(\mathrm{m}^{3} \mathrm{~m}^{-2} \mathrm{~s}^{-1}\right)$

General kinetic constant for the fouling models $\left(\mathrm{s}^{-1}\right)$

Kinetic constant for the cake model $\left(\mathrm{s} \mathrm{m}^{-6}\right)$

Kinetic constant for the intermediate blocking model $\left(\mathrm{m}^{-1}\right)$

Kinetic constant for the standard blocking model $\left(\mathrm{m}^{-3}\right)$

Mass transfer coefficient $\left(\mathrm{m} \mathrm{s}^{-1}\right)$ of each component at impermeable membranes $\left(\mathrm{m} \mathrm{s}^{-1}\right)$

Mass transfer coefficient of each component at semipermeable membranes $\left(\mathrm{m} \mathrm{s}^{-1}\right)$

Low molecular weight compounds

Water permeability $\left(\mathrm{m} \mathrm{Pa}^{-1} \mathrm{~s}^{-1}\right)$

Transversal channel perimeter $(\mathrm{m})$

Reynolds number

Total resistance due to fouling $\left(\mathrm{m}^{-1}\right)$

Resistance due to fouling by high molecular weight compounds $\left(\mathrm{m}^{-1}\right)$

General resistance due to fouling $\left(\mathrm{m}^{-1}\right)$

Resistance due to fouling by low molecular weight compounds $\left(\mathrm{m}^{-1}\right)$

Membranes true retention of each component

Membrane resistance $\left(\mathrm{m}^{-1}\right)$

System resistance $\left(\mathrm{m}^{-1}\right)$

Schmidt number 


$\begin{array}{ll}\text { Sh } & \text { Sherwood number } \\ v & \text { Average velocity inside the channel }\left(\mathrm{m} \mathrm{s}^{-1}\right) \\ V_{p} & \text { Permeate volume }(\mathrm{m}) \\ C_{m T} & \text { Total sugar concentration on the membrane active layer }\left(\mathrm{kg} \mathrm{m}^{-3}\right)\end{array}$

Greek

$\Delta p \quad$ Applied transmembrane pressure $(\mathrm{Pa})$

$\Delta \pi \quad$ Osmotic pressure gradient $(\mathrm{Pa})$

$\eta_{f} \quad$ feed viscosity (Pa s)

$\phi_{i} \quad$ ratio of the permeate flux by the mass-transfer coefficient of the component i at impermeable membranes

$\rho_{f} \quad$ Feed density $\left(\mathrm{kg} \mathrm{m}^{-3}\right)$

$\Xi_{i} \quad$ Correction factor by which $\mathrm{K}_{\mathrm{m}, \mathrm{i}}$ must be multiplied to obtain $\mathrm{K}_{\mathrm{m}, \mathrm{i}}^{\star}$ 


\subsection{References}

[1] R. Mira de Orduña, Climate change associated effects on grape and wine quality and production, Food Research International, 43 (2010) 1844-1855.

[2] N. Garcia-Martin, S. Perez-Magarino, M. Ortega-Heras, C. Gonzalez-Huerta, M. Mihnea, M.L. Gonzalez-Sanjose, L. Palacio, P. Pradanos, A. Hernandez, Sugar reduction in white and red musts with nanofiltration membranes, Desalination and water treatment, 27 (2011) 167-174.

[3] M. Howley, N. Young, Low-alcohol Wines: The Consumer's Choice?, International Journal of Wine Marketing, 4 (1992) 45-46.

[4] J. Masson, P. Aurier, F. d'hauteville, Effects of non-sensory cues on perceived quality: the case of low-alcohol wine, International Journal of Wine Business Research, 20 (2008) 215-229.

[5] J. Labanda, S. Vichi, J. Llorens, E. López-Tamames, Membrane separation technology for the reduction of alcoholic degree of a white model wine, LWT - Food Science and Technology, 42 (2009) 1390-1395.

[6] G.J. Pickering, Low- and Reduced-alcohol Wine: A Review, Journal of Wine Research, 11 (2000) 129-144.

[7] Y.Y. Belisario-Sánchez, A. Taboada-Rodríguez, F. Marín-Iniesta, A. López-Gómez, Dealcoholized Wines by Spinning Cone Column Distillation: Phenolic Compounds and Antioxidant Activity Measured by the 1,1-Diphenyl-2-picrylhydrazyl Method, J. Agric. Food Chem., 57 (2009) 6770-6778.

[8] S.V. Makarytchev, T.A.G. Langrish, D.F. Fletcher, Mass Transfer Analysis of Spinning Cone Columns Using CFD, Chemical Engineering Research and Design, 82 (2004) 752-761.

[9] M. Catarino, A. Mendes, Dealcoholizing wine by membrane separation processes, Innovative Food Science \& Emerging Technologies, 12 (2011) 330-337.

[10] G.J. Pickering, D.A. Heatherbell, M.F. Barnes, Optimising glucose conversion in the production of reduced alcohol wine using glucose oxidase, Food Research International, 31 (1998) 685-692.

[11] I.C. Huseyin Erten, The Production of Low-Alcohol Wines by Aerobic Yeasts, Journal of The Institute of Brewing, 107 (2001) 207 - 215.

[12] OIV, International Code of Oenological Practices, OIV, Paris, 2012.

[13] A. Cassano, A. Mecchia, E. Drioli, Analyses of hydrodynamic resistances and operating parameters in the ultrafiltration of grape must, Journal of Food Engineering, 89 (2008) 171-177. 
[14] A. Versari, R. Ferrarini, G.P. Parpinello, S. Galassi, Concentration of Grape Must by Nanofiltration Membranes, Food and Bioproducts Processing, 81 (2003) 275-278.

[15] A. Rektor, A. Kozak, G. Vatai, E. Bekassy-Molnar, Pilot plant RO-filtration of grape juice, Separation and Purification Technology, 57 (2007) 473-475.

[16] N. García-Martín, S. Perez-Magariño, M. Ortega-Heras, C. González-Huerta, M. Mihnea, M.L. González-Sanjosé, L. Palacio, P. Prádanos, A. Hernández, Sugar reduction in musts with nanofiltration membranes to obtain low alcohol-content wines, Separation and Purification Technology, 76 (2010) 158-170.

[17] L. Takács, G. Vatai, K. Korány, Production of alcohol free wine by pervaporation, Journal of Food Engineering, 78 (2007) 118-125.

[18] N. García-Martín, L. Palacio, P. Prádanos, A. Hernández, M. Ortega-Heras, S. Pérez-Magariño, D.C. González-Huerta, Evaluation of several ultra- and nanofiltration membranes for sugar control in winemaking, Desalination, 245 (2009) 554-558.

[19] I. Kiss, G. Vatai, E. Bekassy-Molnar, Must concentrate using membrane technology, Desalination, 162 (2004) 295-300.

[20] P. Pradanos, J.I. Arribas, A. Hernandez, Flux Limiting Factors in Cross-flow Ultrafiltration of Invertase through an Asymmetric Inorganic Membrane, Separation Science and Technology, 28 (1993) 1899-1911.

[21] P. Prádanos, J. de Abajo, J.G. de la Campa, A. Hernández, A comparative analysis of flux limit models for ultrafiltration membranes, Journal of Membrane Science, 108 (1995) 129-142.

[22] R.C. Kuhn, F. Maugeri Filho, V. Silva, L. Palacio, A. Hernández, P. Prádanos, Mass transfer and transport during purification of fructooligosaccharides by nanofiltration, Journal of Membrane Science, 365 (2010) 356-365.

[23] P. Prádanos, J.I. Arribas, A. Hernández, Retention of proteins in cross-flow UF through asymmetric inorganic membranes, AIChE Journal, 40 (1994) 1901-1910.

[24] V. Geraldes, M.D. Afonso, Prediction of the concentration polarization in the nanofiltration/reverse osmosis of dilute multi-ionic solutions, Journal of Membrane Science, 300 (2007) 20-27.

[25] M.W. Chudacek, A.G. Fane, The dynamics of polarisation in unstirred and stirred ultrafiltration, Journal of Membrane Science, 21 (1984) 145-160

[26] L.J. Zeman, Adsorption effects in rejection of macromolecules by ultrafiltration membranes, Journal of Membrane Science, 15 (1983) 213-230.

[27] J.H. Hanemaaijer, T. Robbertsen, T. Van Den Boomgaard, C. Olieman, P. Both, D.G. Schmidt, Characterization of clean and fouled ultrafiltration membranes, Desalination, 68 (1988) 93-108. 
[28] W.R. Bowen, J.I. Calvo, A. Hernández, Steps of membrane blocking in flux decline during protein microfiltration, Journal of Membrane Science, 101 (1995) 153-165

[29] M.N.A. Seman, M. Khayet, N. Hilal, Nanofiltration thin-film composite polyester polyethersulfone-based membranes prepared by interfacial polymerization, Journal of Membrane Science, 348 (2010) 109-116.

[30] P. Prádanos, A. Hernández, J.I. Calvo, F. Tejerina, Mechanisms of protein fouling in cross-flow UF through an asymmetric inorganic membrane, Journal of Membrane Science, 114 (1996) 115-126.

[31] G. Jonsson, P. Prádanos, A. Hernández, Fouling phenomena in microporous membranes. Flux decline kinetics and structural modifications, Journal of Membrane Science, 112 (1996) 171-183.

[32] J.C. Schippers, J. Verdouw, The modified fouling index, a method of determining the fouling characteristics of water, Desalination, 32 (1980) 137-148.

[33] Estación Enológica, Instituto Tecnológico Agrario, Conserjería de Agricultura y Ganadería de Castilla y León. Personal communication of Grape must analysis, in, Rueda, Valladolid, Spain, 2010.

[34] A. Madrid, J.M. Cenzano, A.M. Cenzano, Tecnología y legislación del vino y bebidas derivadas, IRAGRA, S.A., Madrid, 1994.

[35] A. Al-Amoudi, P. Williams, S. Mandale, R.W. Lovitt, Cleaning results of new and fouled nanofiltration membrane characterized by zeta potential and permeability, Separation and Purification Technology, 54 (2007) 234-240.

[36] OIV, Compendium of International Methods of Wine and Must Analysis, OIV, Paris, 2011.

[37] M. Vidal, J. Blouin, Dosage colorimetrique rapide d lacide tartarique dans les moust et les vins, Rev Fr. Oenol., 70 (1978) 39 - 46.

[38] B.W. Zoecklein, K.C. Fuglesang, B.H. Gump, F.S. Nury, Wine analysis and production, Chapman \& Hall, New York, 1995.

[39] V. Kochkodan, N. Hilal, V. Melnik, O. Kochkodan, O. Vasilenko, Selective recognition of organic pollutants in aqueous solutions with composite imprinted membranes, Advances in Colloid and Interface Science, 159 (2010) 180-188.

[40] K. Listiarini, D.D. Sun, J.O. Leckie, Organic fouling of nanofiltration membranes: Evaluating the effects of humic acid, calcium, alum coagulant and their combinations on the specific cake resistance, Journal of Membrane Science, 332 (2009) 56-62.

[41] K. Listiarini, W. Chun, D.D. Sun, J.O. Leckie, Fouling mechanism and resistance analyses of systems containing sodium alginate, calcium, alum and their combination in dead-end fouling of nanofiltration membranes, Journal of Membrane Science, 344 (2009) 244-251. 
[42] P. Prádanos, Estudio y Caracterización de Membranas de Ultrafiltración. Su aplicación a Procesos de Interés Enológico, PhD Thesis, Secretariado de Publicaciones de la Universidad de Valladolid, ISBN 84-7762-524-7, Valladolid, (1994). [43] D.R. Lide, Handbook of Chemistry and Physics, Internet version 2006, in, Taylor and Francis, Boca Raton, 2006.

[44] J. Hidalgo - Togores, Calidad del vino desde el viñedo, Mundi- Prensa, Madrid, 2006.

[45] C.A. Zuritz, E.M. Puntes, H.H. Mathey, E.H. Pérez, A. Gascón, L.A. Rubio, C.A. Carullo, R.E. Chernikoff, M.S. Cabeza, Density, viscosity and coefficient of thermal expansion of clear grape juice at different soluble solid concentrations and temperatures, Journal of Food Engineering, 71 (2005) 143-149.

[46] H. Uedaira, H. Uedaira, Translational frictional coefficients of molecules in aqueous solution, J. Phys. Chem., 74 (1970) 2211-2214.

[47] G. Foley, D.M. Malone, F. MacLoughlin, Modelling the effects of particle polydispersity in crossflow filtration, Journal of Membrane Science, 99 (1995) 77-88. 



\section{Chapter 4}

\section{Fouling study of Nanofiltration membranes for sugar control in grape must. Analysis of resistances and the role of osmotic pressure}

Camila M.. Salgado ${ }^{1}$, Francisco.J. Carmona ${ }^{2}$, Laura. Palacio ${ }^{1}$, Antonio. Hernández ${ }^{1}$, Pedro. Prádanos ${ }^{1}$

${ }^{1}$ Grupo de Superficies y Materiales Porosos (SMAP, UA-UVA-CSIC), Dpto. de Física Aplicada, Facultad de Ciencias, Universidad de Valladolid, 47071 Valladolid, Spain.

${ }^{2}$ Dpto. de Física Aplicada. Esc. Politécnica. Universidad de Extremadura, 10003. Cáceres, Spain.

This chapter has been accepted for publication in the journal:

Separation Science and Technology 



\section{Chapter 4. Fouling study of Nanofiltration membranes for sugar control in grape} must. Analysis of resistances and the role of osmotic pressure

\section{Abstract}

Three membranes are analyzed attending to their retention, flux and fouling when used to nanofiltrate sugars in red grape musts. In presence of high molecular weight compounds, i.e. when filtering must, fouling develops from initial pore blocking to final cake deposition. A decrease of resistance appears due to a decrease of the effective transmembrane pressure and cake compaction. The final effective pore size corresponds to that of the compacted cake.

Attending to flux decay and sugar retention, two membranes, HL and SR3, are appropriate to reduce the content of sugar of red must. Specifically SR3 shows the best passage of sugar and less fouling.

Keywords:

Must nanofiltration, Fouling, Osmotic pressure, Cake Compaction, Pore size 


\subsection{Introduction}

Membrane technology has been increasingly used in the beverage industry. For example, it has been successfully used for the recovery of low molecular weight polyphenols and polysaccharides coming from winery effluents [1]. Moreover, it is considered as an alternative concentration method of different fruit juices such as apple, pear [2] or grape must [3]. These processes play an important role in the beverage and wine industry as preservation and concentration methods. The concentrates are a natural sweetener in the production of wine and vitamin- and aroma-rich drinks.

If the molecular weight of sugars in must is taken into account, nanofiltration (NF) is the membrane process to be chosen to retain them. It has been successfully used to increase the sugar content of grape must (to increase the final alcohol degree) in wine production [4]. Using a two stage NF process of grape must, Versari et al. [4] obtained relatively high sugar retentions (7-97\%). Moreover, in their work GarcíaMartin et al. $[5,6]$ studied the sugar reduction in musts by a two stage nanofiltration process to obtain wines with a slight alcohol reduction.

One of the main obstacles of NF technology is membrane fouling. Fouling in general causes deterioration in permeate quality and quantity, and eventually leads to a mandatory and expensive membrane replacement routine [7]. This is because the dominant mechanism of fouling in NF processes is the formation of a layer (a "cake") that can significantly degrade membrane performance [8]. The conventional cake filtration theory consists in a compilation of knowledge of the dynamics of cake filtration developed by Ruth [9] and successive researchers [10-14]. This approach states that during filtration, the cake thickness increases with time. In most cases, it also becomes more compact and its resistance to fluid flow increases accordingly. The main features of the dynamic behavior of cake filtration are the variation of the cake thickness, the evolution of the cake structure, specific cake resistance and total filtered volume for a specified set of operating conditions $[15,16]$.

During the last years, there has been a great development and improvement in optical and thermal techniques which give unquestionable testimony of fouling and allow the study of membrane fouling mechanisms. For example, confocal scanning laser microscopy (CSLM) has been used by Ferrando and coworkers [17] to visualize and characterize membrane's surface and pores, after the microfiltration of protein solutions. More recently infrared thermography (IRT) has been used to characterize fouled membranes by measuring surface temperature and emissivity of different 
foulants [18]. Moreover, Lanteri et al. [19] developed a streaming potential method for the characterization of surface electrical properties of particle deposits during filtration by measuring simultaneously transversal streaming potential and permeate flux during cake growth.

However, most studies on membrane fouling characterization focus on the evolution of permeate flux and total resistance versus time. Fouling mechanisms during membrane filtration processes (i.e. Micro MF, and Ultrafiltration, UF) have been studied in deepness along the last century [20-25]. Subsequently, Schippers and Verdow [26] studied the mechanisms involved during the performance of Reverse osmosis (RO) membranes. More recently, Listiarini and coworkers [7, 27] and Koo et al. [28] applied these mechanisms to the analysis of fouling for NF membranes.

In our previous work [29], a method was proposed to allow studying individually the resistances and fouling mechanism generated by low and high molecular weight solutes, LMW and HMW respectively, in red grape must NF.

The aim of the present work is to analyze in deepness the fouling mechanism, osmotic pressure and resistances of different NF membranes during the filtration of commercial grape must. The assessment of these results and their influence on the performance of NF membranes will give elements for an adequate selection of appropriate membranes for sugar control in grape must.

For this purpose, the methodology suggested in previous studies [29] has been applied in order to analyze individually the influence of LMW and HMW compounds on $\mathrm{NF}$ and this information used to select the best out of three particular membranes.

\subsection{Theory}

\subsubsection{Permeate flux decrease and retention model}

When the overall filtration process is taken into account, the flux through the membrane per unit of membrane area can be written in terms of the applied transmembrane (hydraulic) pressure, $\Delta p_{h, s}$, the osmotic pressure gradient, $\Delta \pi_{s}$, the viscosity of the solution that goes through the pores of the membrane, $\eta_{p}$, and the system resistance. This is the sum of the membrane resistance, $R_{m}$, and the terms that depend on the fouling caused by the LMW $\left(R_{f L M W}\right)$ and the HMW $\left(R_{f H M W}\right)$ solutes [3033]. In this way the permeate flow $\left(J_{v}\right)$ can be calculated as 


$$
J_{v}=\frac{\Delta p_{h, s}-\Delta \pi_{s}}{\eta_{p}\left(R_{m}+R_{f}\right)}=\frac{\Delta p_{h, s}-\Delta \pi_{s}}{\eta_{p}\left(R_{m}+R_{f L M W}+R_{f H M W}\right)}
$$

Since the concentration of monovalent ionic species (potassium and sodium) is similar on both sides of the membrane $[5,6]$ and the concentration of divalent ions (calcium and magnesium) and organic acids is much lower than that of sugars [29], the increase of osmotic pressure can be determined by taking only into account the contribution of glucose and fructose by means of the van't Hoff's law:

$$
\Delta \pi_{s}=\sum_{i=1}^{N} \Delta \pi_{s, i}=\sum_{i=1}^{N} \frac{\mathrm{R} T}{M_{i}}\left(C_{\mathrm{m}, i}-C_{\mathrm{p}, i}\right)
$$

components contributing to the osmotic pressure drop through the membrane system (here $\mathrm{N}=2$ and $\mathrm{i}$ is glucose and fructose), $\mathrm{R}$ the gas constant and $\mathrm{T}$ the temperature. $C_{m, i}$ and $C_{p, i}$ are the concentrations on the membrane system interfaces at the feed and permeate sides respectively.

The concentration on the feed membrane system interface, $C_{m, i}$ can be calculated by taking into account the concentration polarization phenomenon [34], which can be studied by following the Film theory [35-37] as:

$$
C_{m, i}=C_{p, i}+\left(C_{0, i}-C_{p, i}\right) e^{\left(J_{v} / K_{m, i}\right)}
$$

Here $K_{m, i}$ is the mass transfer coefficient of the $i$-th component that can be evaluated by means of the Harriot - Hamilton equation [38] as mentioned in a previous work [29].

\subsubsection{Fouling mechanisms}

NF membranes have very narrow pores as compared to the solute size. Hence, fouling mechanisms where it is assumed that all the solute molecules plug a pore (complete blocking); or are deposited inside the pores (standard blocking) seem inappropriate. Rather, molecules could deposit on other previously settled on the membrane surface or directly plug a pore as assumed in the so called intermediate blocking. Therefore, for the synthetic solution nanofiltration, so as for the first steps of must nanofiltration, flux decay should be caused by the intermediate blocking mechanism according to $[24,25]$ 
$\ln J_{v}(t)=-\kappa_{i} \frac{V_{p}(t)}{A_{m}}+\ln J_{v, 0}$

where $\kappa_{i}$ is the intermediate blocking kinetic constant in $\mathrm{m}^{-1}, V_{\mathrm{P}}$ is the permeated volume in $\mathrm{m}^{3}$ and $A_{\mathrm{m}}$ the membrane surface area in $\mathrm{m}^{2}$.

After saturation of the intermediate mechanism, a cake would be built. According to this model $J_{v}$ can be described as

$$
\frac{t}{V_{\mathrm{P}}(t)}=\frac{\kappa_{\mathrm{c}}}{2} V_{\mathrm{P}}(t)+\frac{1}{J_{v, 0} A_{m}}
$$

where the kinetic constant $\kappa_{c}$ (in $\mathrm{s} \cdot \mathrm{m}^{-6}$ ) is twice the Modified Fouling Index (MFI) that is defined as the slope of the plot of $t / V_{P}$ versus $V_{P}[26,28]$.

\subsubsection{Pressure drops along the membrane system}

As mentioned, in cake filtration mechanisms, the feed has to overcome two resistances that are placed in series: that of the membrane and that of the layer formed due to the fouling (cake).

In the same way, the effective applied pressure drop, the hydraulic pressure applied and the osmotic pressure through the membrane system at any time should be the sum of the contributions of both the membrane and the cake. Then:

$$
\left.\begin{array}{l}
\Delta p_{e f f, s}=\Delta p_{e f f, m}+\Delta p_{\text {eff,c }} \\
\Delta p_{h, s}=\Delta p_{h, m}+\Delta p_{h, c} \\
\Delta \pi_{s}=\Delta \pi_{m}+\Delta \pi_{c}
\end{array}\right\}
$$

where:

$$
\left.\begin{array}{l}
\Delta p_{\text {eff,s }}=\Delta p_{h, s}-\Delta \pi_{s} \\
\Delta p_{\text {eff, } m}=\Delta p_{h, m}-\Delta \pi_{m} \\
\Delta p_{\text {eff }, c}=\Delta p_{h, c}-\Delta \pi_{c}
\end{array}\right\}
$$

Therefore, according to Eq. (1), each effective pressure can be calculated as

$$
\Delta p_{e f f, k}=J_{v} \eta_{P} R_{k} \quad k=s, \text { mor } c
$$


Now we need to know $\Delta \pi_{k}$ to get $\Delta p_{h, k}$ or vice versa from data on the resistances.

According to Eq. (2) we can get the osmotic pressure difference once the concentration on the membrane active layer, $C_{m, i}$ is known. When these calculations are done for the synthetic solution $C_{m, i}$ is the concentration of glucose or fructose on the membrane active layer because no cake would appear and can be determined with Eq (3).

But, according to the definition of the true retention of the solutes, Ri (i.e. for glucose and fructose) [29] is:

$$
R_{i}=1-\frac{C_{\mathrm{p}, i}}{C_{\mathrm{m}, i}}
$$

When grape must is filtered, $C_{m, i}^{\prime}$ is the concentration of the i-th component on the feed-cake interface and can be calculated also by means of Eq (3). In this case, the concentration of the i-th component on the membrane-cake interface $C_{m, i}$, can be calculated by Eq. (9), if it is accepted that the true retention of sugars through the membrane is equal to that evaluated for the synthetic solution filtration and that it behaves in the same way when the cake appears as when it is not present. This is acceptable since true retention is not a concentration dependent parameter for neutral species although it wouldn't be applicable for charged substances. This statement also implies that retentions in the synthetic solution do not vary with permeate flux. The later will be shown in the experimental results (section 4.4.6) were it will be see that $R_{i}$ varies very little with $J_{v}$ for all the membranes under study.

Eq. (2) allows the evaluation of both $\Delta \pi_{m}$ and $\Delta \pi_{s}$. Then, by Eqs. (7) and (8), $\Delta p_{h, k}$ can be calculated. Consequently, all the osmotic addends and pressure drops along the membrane system could be evaluated by using Eqs. (6) and (7).

\subsubsection{Specific cake resistance. Principles of cake filtration.}

The cake sheet formed over the membrane consists in a thin layer of solid particles through which the permeate flows. The specific cake resistance represents the fouling resistance caused by the cake on the membrane, $R_{f}$, normalized by the accumulated cake mass per unit of membrane area [27], so 
$\alpha=\frac{R_{f} A_{m}}{m_{c}}$

Thus, according to Eq. (1), for the cake:

$\alpha=\frac{\Delta p_{\text {eff,c }} A_{m}}{\eta_{p} J_{v} m_{c}}$

where $m_{c}$ is the mass of the cake deposited on the membrane surface.

A material balance allows the correlation of $m_{\mathrm{c}}$ with the permeate volume $V_{\mathrm{P}}$ (volume collected up to time $t$ ). If $C_{\mathrm{b}}$ is the bulk concentration of foulants, the mass of the particles deposited onto the membrane can be correlated to the permeate volume as

$m_{c}=\gamma V_{p} C_{b}$

where $\mathrm{Y}$ is a particle deposition factor (less than unity) that accounts for the reduction of cake mass due to its partial removal induced by the crossflow conditions. This coefficient was first proposed by Sioutopoulos et al. [39] in order to extrapolate specific cake resistance calculations to cross flow conditions.

Therefore Eq. (10) could be used to evaluate $\alpha$ if $C_{\mathrm{b}}$ were known, and Eq. (11) can be used to get $\Delta p_{\text {eff,c }}$.

In order to calculate $C_{b}$ along the filtration process, the following assumptions must be made:

The global concentration of foulants is considered to be that of the total dry extract of must, $C_{D E}$, which includes all matter that is non-volatile. This concentration was defined and determined in accordance to the OIV methods [40].

All the HMW compounds are always retained by the membrane; therefore the mass of these particles in the retentate side, $m_{H M w}$, is considered to be constant during the process.

Only the variation of the concentrations of glucose and fructose in the retentate were taken into account since their concentration is so high that the variation of the other LMW is considered negligible.

In accordance to these ideas, the concentration of HMW can be obtained as

$$
C_{H M W}=C_{D E}-C_{T, O}
$$


where $C_{T, 0}$ is the initial total sugar concentration (glucose and fructose). Moreover

$$
m_{H M W}=C_{H M W} V_{0}
$$

$V_{0}$ being the initial volume of must.

Finally, $C_{\mathrm{b}}$ can be evaluated, as a function of time, by

$$
C_{b}(t)=\frac{m_{H M W}+m_{T R}(t)}{V_{R}(t)}
$$

where $m_{T R}(t)$ is the total sugar content and $V_{R}(t)$ the volume of the retentate at the filtration time $t$. Then, by using Eqs. (12) and (8), Eq. (11) can be used to calculate $\alpha$.

Another strategy could be used for the estimation of $\alpha$. In effect, according to Eqs. (1), (5) and (11), $\kappa_{c}$, that can be determined from the flux kinetics according to

$$
\kappa_{c}=\frac{\gamma \eta_{p} C_{b} \alpha}{A_{m}^{2} \Delta p_{e f f, s}}
$$

where, $\Delta p_{\text {eff,s }}$ is known because $\Delta \pi_{\mathrm{s}}$ can be evaluated by Eq. (2).

\subsubsection{Pore size evolution}

Apparent pore size can be used to study flux decay through the analysis of its evolution. In order to estimate pore size, a convection-difussion model was used. This model considers only the steric partitioning in the interface, with the introduction of the applied pressure gradient term as has been previously described [41]. In these terms, the retention coefficient that a NF membrane presents can be written as

$$
R=1-\frac{K_{\mathrm{c}} \phi}{1-\left(1-K_{\mathrm{c}} \phi\right) e^{-P e}}
$$

In this expression, the steric partition coefficient is $\phi=\left(1-r_{i} / r_{p}\right)^{2}$ if a cylindrical geometry is assumed for the pores, being $r_{i}$ and $r_{p}$ the i-th component and pore radii respectively. The dimensionless Peclet number is given by: 
$P e=\frac{K_{\mathrm{c}} J_{V}}{K_{\mathrm{d}} D_{\mathrm{i}}}\left(\frac{\Delta x}{A_{k}}\right)=\frac{K_{\mathrm{c}} J_{V}}{K_{\mathrm{d}} D_{i}}\left(\frac{r_{\mathrm{p}}^{2}}{8 L_{\mathrm{p}} \bar{\eta}}\right)$

where $L_{p}$ is the water permeability, $\bar{\eta}$ the viscosity inside the pore, and $\Delta x$ and $A_{k}$ are the thickness and porosity of the membrane respectively. $K_{\mathrm{c}}$ and $K_{\mathrm{d}}$. represent the hindrance factors for convection and diffusion, respectively. According to Dechadilok and Deen [42] these factors can be calculated according to polynomes that depend on $\lambda=r_{i} / r_{p}$.

For the viscosity inside the pore, the model proposed by Wesolowska et al.[43] was adopted defining a factor $y=d / r_{\mathrm{p}}$, and $d=0.28 \mathrm{~nm}$.

Through this set of relations, the retention coefficient, $R$, is a function of the pore radius, $r_{p}$. From a set of data, of $J_{v}$ and $R$, the pore radius could be estimated as the free parameter in the best fit to Eq. (18). In this work, instead of using the whole data set to estimate a unique $r_{p}$ average value, each pair of values $\left(J_{v}, R\right)$ were used to calculate the corresponding $r_{\mathrm{p}}$ from Eq. (18). As the filtration process modify flux rate and retention coefficient along the process, $r_{\mathrm{p}}$ changes with time too as logical.

\subsection{Materials and methods}

\subsubsection{Membranes and experimental set-up}

Three different nanofiltration flat sheet membranes were tested: NF270 from Dow - Filmtec (the flatsheets were kindly supplied by the manufacturer); HL from GE Water \& Process Technologies and KMS SR3 from Koch Membrane systems. The main characteristics of them are shown in Table 4.1. The molecular weight cutoff, MWCO, was provided by the manufacturer for the SR3 and HL and in the case of the NF270 it wasobtained from different studies were the membrane was used [44], [35]. Drop contact angles were obtained from the literature [45], [46], [47].

The experimental set-up used in this study is described in sufficient detail elsewhere [29] thus only a brief summary is provided here. All the experiments were performed in a batch unit without dilution with a stainless steel flat sheet crossflow module with a single channel of length $L=110 \mathrm{~mm}$; height $H=0.5 \mathrm{~mm}$ and width $W=60$ $\mathrm{mm}$. These dimensions provide a membrane surface area $A_{m}=6.6 \cdot 10^{-3} \mathrm{~m}^{2}$.

The operating conditions for every filtration process were: feed temperature of $20^{\circ} \mathrm{C}$, applied pressure of $35 \cdot 10^{5} \mathrm{~Pa}$ and retentate recirculation flow of $5 \mathrm{~L} / \mathrm{min}$. 
According to the dimensions of the channel, this supposes a feed tangential velocity on the membrane surface of $2.78 \mathrm{~m} / \mathrm{s}$.

Table 4.1. Main characteristics of the membranes

\begin{tabular}{|c|c|c|c|c|c|c|c|}
\hline \multirow[b]{2}{*}{ Membrane } & \multirow[b]{2}{*}{ Manufacturer } & \multirow[b]{2}{*}{$\begin{array}{c}\text { MWCO } \\
\text { (Da) }\end{array}$} & \multirow{2}{*}{$\begin{array}{c}\mathrm{MgSO}_{4} \\
\text { Rejection } \\
(\%)\end{array}$} & \multicolumn{3}{|c|}{ Operating range } & \multirow{2}{*}{$\begin{array}{c}\text { Drop } \\
\text { Contact } \\
\text { angle } \\
(\stackrel{0}{)})\end{array}$} \\
\hline & & & & $\mathrm{pH}$ & $\begin{array}{c}P \\
\left(10^{5} \mathrm{~Pa}\right)\end{array}$ & $\begin{array}{c}\mathrm{T} \\
\left({ }^{\circ} \mathrm{C}\right)\end{array}$ & \\
\hline NF270 & Dow & $200^{a}-400^{b}$ & $97^{\mathrm{c}, \mathrm{d}}$ & $3-10$ & $<41$ & $<45$ & $30^{g}$ \\
\hline HL & GE Water & $150^{c}-300^{c}$ & $98^{\mathrm{c}, \mathrm{e}}$ & $3-10$ & $<40$ & $<50$ & $27.5^{h}$ \\
\hline SR3 & Koch & $200^{c}$ & $99^{\mathrm{c}, \mathrm{f}}$ & $4-10$ & $<44.8$ & $<50$ & $49^{i}$ \\
\hline
\end{tabular}

a [44], ${ }^{b}$ [35], ${ }^{\mathrm{C}} \mathrm{According}$ to the information provided by the manufacturers, ${ }^{\mathrm{d}} \mathrm{MgSO}_{4} 2000 \mathrm{mg} / \mathrm{L}$ at $480 \mathrm{kPa},{ }^{\mathrm{e}} \mathrm{MgSO}_{4} 2000 \mathrm{mg} / \mathrm{L}$ at $690 \mathrm{kPa},{ }^{\mathrm{f}} \mathrm{MgSO}_{4} 5000 \mathrm{mg} / \mathrm{L}$ at $655 \mathrm{kPa},{ }^{\mathrm{g}}$ [45], ${ }^{\mathrm{h}}[46],{ }^{\mathrm{i}}[47]$.

\subsubsection{Synthetic solution and commercial grape must}

Two NF processes were performed for each membrane. Firstly, a synthetic solution prepared in the laboratory containing the main low molecular weight compounds (LMW) of grape must was filtered. These are namely glucose (Glu), fructose (Fru), malic and tartaric acids, potassium, sodium, calcium and magnesium. The concentrations of this synthetic solution were the same that those reported in a previous work [29]

Then it was carried out the filtration of commercial red must, which also contains high molecular weight compounds (HMW) such as polyphenols, polysaccharides and proteins. Attempting to reproduce the same conditions as in the first filtrate, the experiments with grape must were made using a brand new membrane flat sheet.

In this way, it was possible to analyze individually the influence of these HMW and LMW compounds on: the permeate flux decline, the true retention, the fouling mechanism and the resistances to the permeate flux.

\subsubsection{Experimental protocol}

The experimental protocol can be summarized as:

1. Membrane compaction was performed during one hour using Milli-Q water at $35 \cdot 10^{5} \mathrm{~Pa}, 20 \stackrel{\circ}{\circ} \mathrm{C}$ and a recirculation flow of $5 \mathrm{~L} / \mathrm{min}$, in order to avoid irreversible changes during operation. Under these conditions water 
permeability was determined. This measurement was repeated before and after all filtration and cleaning steps.

2. The membrane was soaked in the synthetic solution for 12 hours at $20-25^{\circ} \mathrm{C}$. This was done to allow an initial deposition of foulants.

3. Nanofiltration of the synthetic solution of LMW at the operating conditions mentioned in 4.3.1.

4. Then, the membrane was cleaned with soft water at low pressure, under the same operating conditions of temperature and recirculation flow, during one hour sending both permeate and retentate to the drain. Afterwards it was rinsed with Milli-Q water using at least a volume equal to the system hold-up volume and sending the permeate and retentate to the drain too. Finally, the hydraulic permeability was measured.

5. Compaction and determination of hydraulic permeability of a new membrane sheet (step 1).

6. Soaking of the membrane in commercial red must during 12 hours with the same purpose as in step 2.

7. Nanofiltration of commercial red must at the operating conditions mentioned in 4.3.1.

8. A two stage membrane cleaning procedure consisting in a water rinse step followed by the use of a tensoactive solution of $0.1 \%$ sodium dodecyl sulfate as described in [29]. After each step, hydraulic permeability was measured.

In each nanofiltration process, permeate fluxes were determined by recording the time required to collect a known volume of filtrate $(10 \mathrm{~mL})$, firstly every 15 minutes and when the flux reached more stable values, every 45 minutes. At the same time samples of permeate and retentate were taken in order to determine their glucose and fructose content by liquid chromatography.

As mentioned, the filtration of both the synthetic solution and the red must were carried out in a batch concentration mode. The permeate was sent to the thermostated permeate vessel in order to collect it and the retentate was recirculated to the thermostated feed vessel. The experiments were performed until the permeate flux decreased to a more or less constant value for a reasonable period of time (which depended on the membrane). The volumes filtered were of the order of $2.5 \mathrm{~L}$ of both, synthetic solution and red must. 


\subsubsection{Deposition factor $(\gamma)$}

A significant issue is the extent to which the cross-flow operation may affect particle deposition on the membrane surface and therefore the specific cake resistance. In the present investigation, the deposition factor $\gamma$ was estimated by determining the ratio of the true amount of must foulants deposited on each membrane surface over the theoretical one.

The true mass deposition was determined by calculating the mass difference between each fouled NF membrane and the respective new one. For this purpose, red must filtrations were performed using the three membranes.

Pieces of both, fouled and clean, membrane were dried under temperature (70 $\left.{ }^{\circ} \mathrm{C}\right)$ and pressure $(25 \mathrm{mmHg})$ until reaching a constant weight and the mass difference was measured. These conditions were established by the OIV [40] for grape and wine dry extract determination.

The theoretical cake mass was calculated by considering that all the dry extract of must filtrated was attached to the cake layer on the basis of the total permeate volume of each membrane test.

\subsubsection{Analytical methods}

The chromatography system used for the identification and quantification of glucose and fructose was composed of a Shimadzu ${ }^{T M}$ LC-9A HPLC apparatus, a Shimadzu ${ }^{\mathrm{TM}}$ Refractive Index device with a detector RID 6A, a Rheodyne ${ }^{\mathrm{TM}}$ injector with a $20 \mu \mathrm{L}$ loop and the software Class-VP ${ }^{\mathrm{TM}}$. Separation was carried out isocratically in $100 \%$ deionized water at a flow rate of $0.5 \mathrm{~mL} / \mathrm{min}$ at $85^{\circ} \mathrm{C}$ using a Supelco ${ }^{\mathrm{TM}}$ ion exchange guard column and a Supelcogel ${ }^{\mathrm{TM}} \mathrm{Pb}$ column.

\subsubsection{SEM and AFM microscopy}

The surfaces of the membranes were imaged by Scanning Electron Microscopy, SEM. The samples were put on an aluminum plate and sheltered with a thin metal layer by a Polaron ${ }^{\mathrm{TM}}$ (SC7640 model) Sputter Coater. The electronic imaging device XL30 ES type EM (from Phillips ${ }^{\mathrm{TM}}$ ) was used and several accelerating voltages were applied to reach different magnifications.

Topography of the active layers was also studied through AFM. Images were acquired in the tapping mode at room temperature, with a Nanoscope IIIA microscope from Digital Instruments (of the Veeco ${ }^{\mathrm{TM}}$ Metrology Group). The tip was an Olympus ${ }^{\mathrm{TM}}$ 
OTESPA7 made out of an etched silicon probe aluminum coated with a length of $14 \mu \mathrm{m}$ and an end with a radius of $7 \mathrm{~nm}$. This allowed the minimization of the undesirable convolution of the tip shape and the membrane surface topography [48]. Images were processed by means of the Nanoscope software version 5.30r3.sr3.

\subsection{Results and discussion}

\subsubsection{Permeate flux and permeability}

As mentioned, hydraulic permeability, $L_{P}$, was determined before and after every filtration or cleaning process and for each membrane as the slope of the $J_{V}$ vs $\Delta p$ plot with Milli-Q water ${ }^{\mathrm{TM}}$. From $L_{P}$ data, the initial and final membrane resistances were calculated for $R_{f}=0$ and $\Delta \pi=0$. Results are shown in Table 4.2. It is clear that after the filtration and rinse of the synthetic solution, water permeability was slightly reduced for the three membranes. The main differences were detected after must nanofiltration and cleaning procedure. The SR3 membrane presented the highest permeability recovery (93\%), followed by the HL membrane (70\%) and finally by NF270 (65\%). This means that SR3 has the most reversible fouling, presumably due to a less adhesion of molecules on the membrane surface.

Table 4.2. Hydraulic permeability and resistance of the membranes, initial value and after nanofiltration and cleaning processes.

\begin{tabular}{|c|c|c|c|c|c|c|c|c|}
\hline \multirow[b]{2}{*}{ Membrane } & \multicolumn{4}{|c|}{$\begin{array}{c}\text { Water Permeability } \\
L_{\mathrm{p}}\left(10^{-11} \mathrm{~m} / \mathrm{Pa} \mathrm{s}\right)\end{array}$} & \multicolumn{4}{|c|}{$\begin{array}{l}\text { Membrane resistance } \\
\qquad R_{\mathrm{m}}\left(10^{13} \mathrm{~m}^{-1}\right)\end{array}$} \\
\hline & $\begin{array}{l}\text { Before } \\
\text { filtration }\end{array}$ & $\begin{array}{c}\text { After } \\
\text { synthetic } \\
\text { solution } \\
\text { rinse }\end{array}$ & $\begin{array}{l}\text { After } \\
\text { must } \\
\text { rinse }\end{array}$ & $\begin{array}{c}\text { After } \\
\text { must } \\
\text { cleaning } \\
\text { with SDS }\end{array}$ & $\begin{array}{l}\text { Before } \\
\text { filtration }\end{array}$ & $\begin{array}{c}\text { After } \\
\text { synthetic } \\
\text { solution } \\
\text { rinse }\end{array}$ & $\begin{array}{l}\text { After } \\
\text { must } \\
\text { rinse }\end{array}$ & $\begin{array}{c}\text { After } \\
\text { must } \\
\text { cleaning } \\
\text { with SDS }\end{array}$ \\
\hline NF270 & 3.84 & 3.34 & 2.10 & 2.45 & 2.60 & 2.98 & 4.75 & 4.07 \\
\hline HL & 3.70 & 3.35 & 2.21 & 2.56 & 2.69 & 2.98 & 4.52 & 3.90 \\
\hline KMS SR3 & 2.18 & 2.10 & 1.44 & 1.97 & 4.57 & 4.74 & 6.92 & 5.06 \\
\hline
\end{tabular}

The permeate flux of the synthetic solution and red must filtrations for each membrane are plotted in Figure 4.1. Each point corresponds to an average of three experiments and the error bars plotted represent an error around $8 \%$. In all cases, a decay of flux is observed. Here it can be noticed that the NF270 membrane has clearly the highest flux of the synthetic solution, followed by SR3 and HL. Bigger differences were appreciated mainly at the beginning of the red must NF, when the SR3 membrane presented the highest flux while NF270 and HL presented very similar fluxes, 3 times lower than that for the SR3. Besides, SR3 showed a less-sharp initial 
decline of flux (during approximately the first $170 \mathrm{~min}=10.2 \cdot 10^{3} \mathrm{~s}$ ) followed by a very sharp flux decay. It is worth noting, that after a certain filtration time, the three membranes reached a more or less flat plateau around a quite similar value.

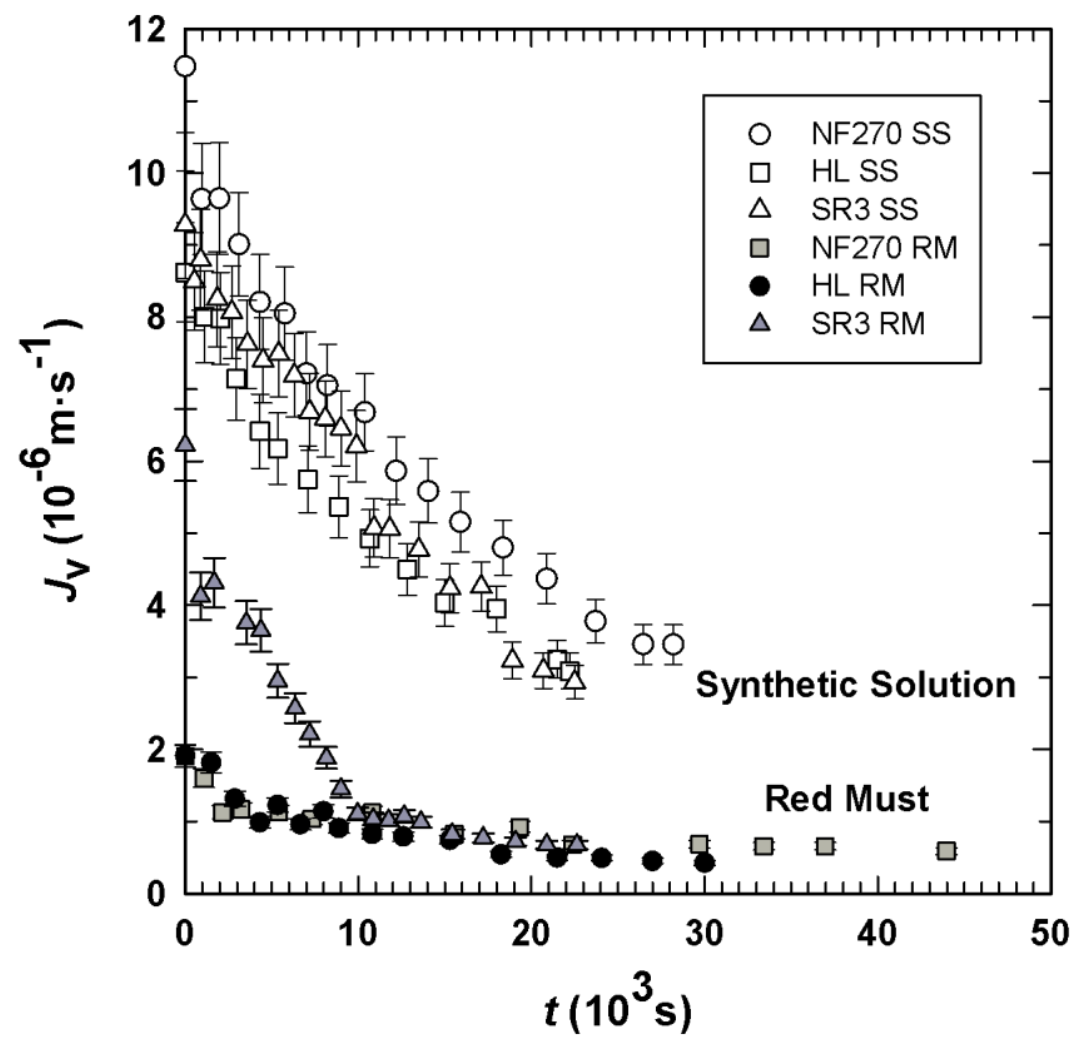

Figure 4.1 Permeate flux time evolution of red must (RM) and synthetic solution (SS) NF for each membrane.

\subsubsection{Sugars retention and passage}

In order to test that the increase of osmotic pressure can be determined by taking into account only the contribution of glucose and fructose the conductivity of the permeates and retentates of each experiment was measured. The difference between them was $0.13 \pm 0.04 \mathrm{mS} \mathrm{cm}^{-1}$ for the synthetic solution and $0.08 \pm 0.04 \mathrm{mS} \mathrm{cm}^{-1}$ for the grape must. This corroborates that the contribution of the ionic species to this parameter can be neglected. Moreover, this is also supported by the studies carried out by Garcia- Martin et al $[5,6]$ using the HL membrane for the NF of grape must. Here they confirmed that the concentration of potassium, malic and tartaric acids do not significantly vary along the process.

In this way, true retentions of glucose and fructose have been evaluated using the equations of section 4.2. The corresponding results are shown in Figure 4.2a (for the synthetic solution) and in Figure 4.2b (for the commercial must) as a function of 
time. Each point is plotted with its corresponding error bar which is around $10 \%$. Errors will not be plotted from now on since they refer to indirect magnitudes derived from the actual results shown in Figures 4.1 and 4.2 and they would mask the graphs and results obtained.
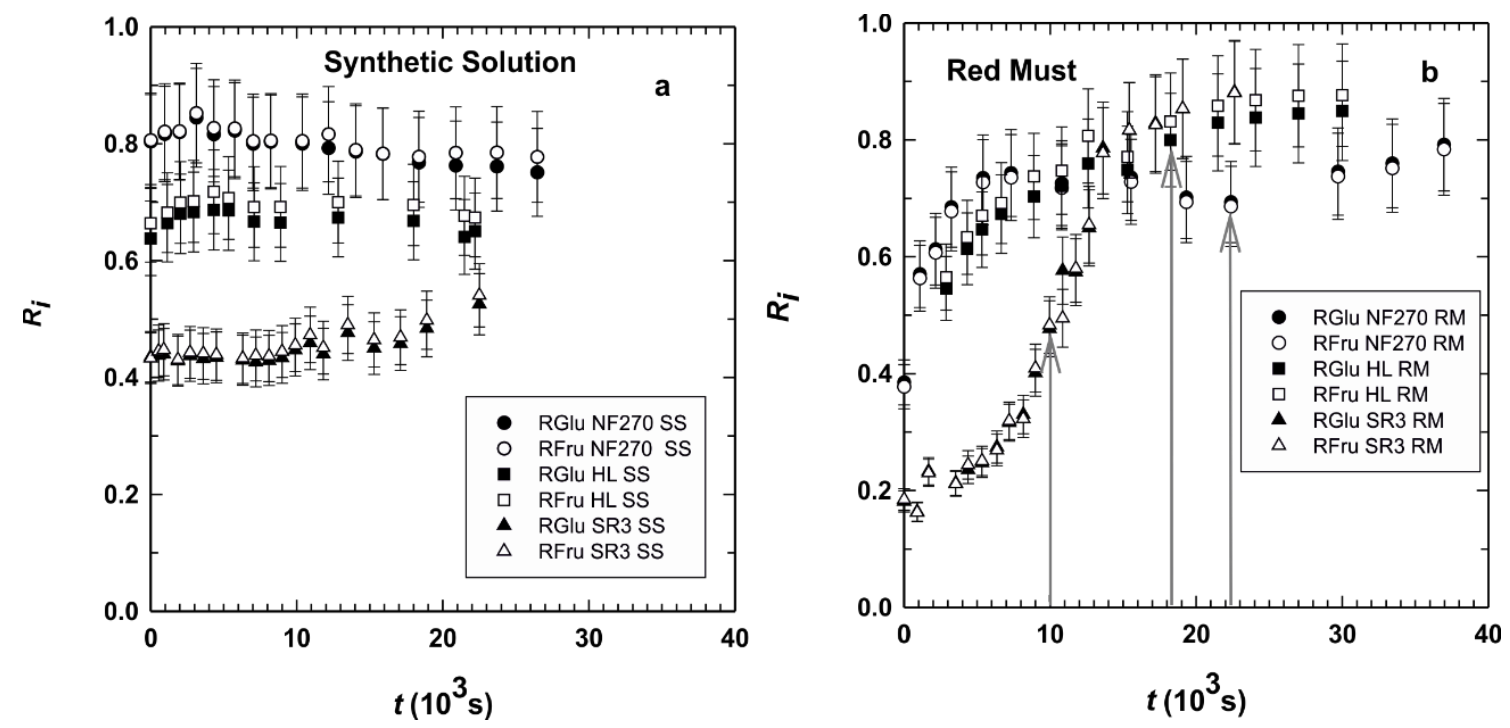

Figure 4.2 Glucose (Glu) and fructose (Fru) retentions as a function of time: (a) for the synthetic solution, (b) for red must [46]. Arrows correspond to maximum total fouling resistances.

Sugars retention remains practically constant during the synthetic solution filtration for the three membranes. Both sugars (glucose and fructose) were retained by all the membranes, especially by NF270 and SR3. NF270 presented the highest retention values (around 0.8 ) followed by $\mathrm{HL}$ (ranging from 0.65 to 0.72 ) and finally by SR3 (between 0.44 and 0.52 ); which is in accordance with the estimated radius for each of them, as we will show below.

These retentions do not agree with the nominal data shown in Table 4.1. According to them, the SR3 membrane is the most retentive one for $\mathrm{MgSO}_{4}$ while NF270 is the less retentive. This different salt rejection could be due to the charge of the membranes and/or to their hydrophillicity. Given that the three membranes have quite similar isoelectric points, around $\mathrm{pH}=3.5[47,49,50]$, the difference must be mainly attributable to their contact angles. In fact, SR3 is the most hydrophobic membrane (see Table 4.1) [45-47], what should explain its high retention of a charged and hydrated salt as $\mathrm{MgSO}_{4}$.

However, as it is shown in Figure 4.2b, the presence of HMW compounds modifies the retention characteristics of the three membranes. The initial retention falls drastically, between 0.2 , for SR3 and 0.4 for NF270, with the same membrane order as shown in the case of the synthetic solution. This decrease in membrane retention during the initial period can be attributed to two factors. First, due to the difference in 
the fluid matrices of the synthetic solution and grape must, the osmotic pressure is slightly lower in the synthetic solution so that the effective pressure is greater in this case and particles are transported to the surface of the membrane more rapidly forming a fouling layer on it. The second aspect to consider is the porosity of the fouling layer. The initial porosity is higher, for the must, due to steric hindrance between HMW molecules that leads to an increase in retention. The long time increase of retention occurs equally for the three membranes, although much steeply for SR3; this and HL present values of $R$ around 0.9 , well above the value (0.8) around which the NF270 finally stabilizes.

This evolution, when HMW compounds are present, must be attributed to the formation, thickening and compaction of a gel layer on the membrane surface that acts as a pseudo-membrane which lowers the passage of sugars through the membrane by changing both: selectivity and permeability of the overall membrane. As seen in Figure $4.2 \mathrm{~b}$, the influence of this pseudo-membrane on the membrane retention is more significant in the case of SR3.

\subsubsection{Analysis of the fouling mechanisms}

In order to analyze the fouling kinetics of both the synthetic solution and the red must filtrations in a quantitative way, the previously outlined fouling models $[7,24,25$, $27,28]$ have been used to fit the experimental data.

The intermediate blocking model seems to be compatible with the data corresponding to the filtration of the synthetic solution and with the first steps of must filtration. The slopes of the synthetic solution fits for the intermediate model, given by Eq. (4), were similar for the three membranes. Note that, the slope is related with the area of the membrane blocked per unit of total volume flown (through $\kappa_{i}$ ). The values for $\kappa_{i}$ are shown in Table 4.3. The highest $\kappa_{i}$ was obtained for HL, followed by SR3 and finally by NF270.

Table 4.3 Kinetic constants for fouling and the deposition factor $\gamma$ for the synthetic solution (SS) and red must (RM) filtrations

\begin{tabular}{|c|c|c|c|c|c|}
\hline \multirow{2}{*}{ Membrane } & \multicolumn{2}{|c|}{$\begin{array}{c}\kappa_{i} \\
\left(m^{-1}\right)\end{array}$} & \multirow{2}{*}{$\frac{\begin{array}{c}\kappa_{\mathrm{c}} \text { (initial) } \\
\left(10^{11} \mathrm{~s} \mathrm{~m}^{-6}\right)\end{array}}{\mathrm{RM}}$} & \multirow{2}{*}{$\frac{\begin{array}{c}\kappa_{c}(\text { final }) \\
\left(10^{11} \mathrm{~s} \mathrm{~m}^{-6}\right)\end{array}}{R M}$} & \multirow{2}{*}{$\begin{array}{c}\gamma \\
\left(10^{-3} \text { dimensionless }\right)\end{array}$} \\
\hline & $\begin{array}{c}\text { SS } \\
\text { global }\end{array}$ & $\begin{array}{c}\mathrm{RM} \\
\text { initial }\end{array}$ & & & \\
\hline SR3 & 8.61 & 88.17 & 1.60 & 8.92 & 1.30 \\
\hline HL & 8.65 & 100.35 & 11.62 & 19.60 & 3.56 \\
\hline NF270 & 6.80 & 120.18 & 5.40 & 6.84 & 1.04 \\
\hline
\end{tabular}


Figure 4.3a shows, as an example, the plots of flux versus the total volume permeated over time for the synthetic solution and red must filtration for SR3, fitted to the intermediate blocking model.

Here it can be seen that the slope is much higher for must than for the synthetic solution revealing a faster fouling kinetics. This should be due to the additional pore blocking caused by the high molecular weight compounds probably affecting the widest pores in the membrane.

The corresponding kinetic constants for the three membranes and the synthetic solution are shown in Table 4.3.
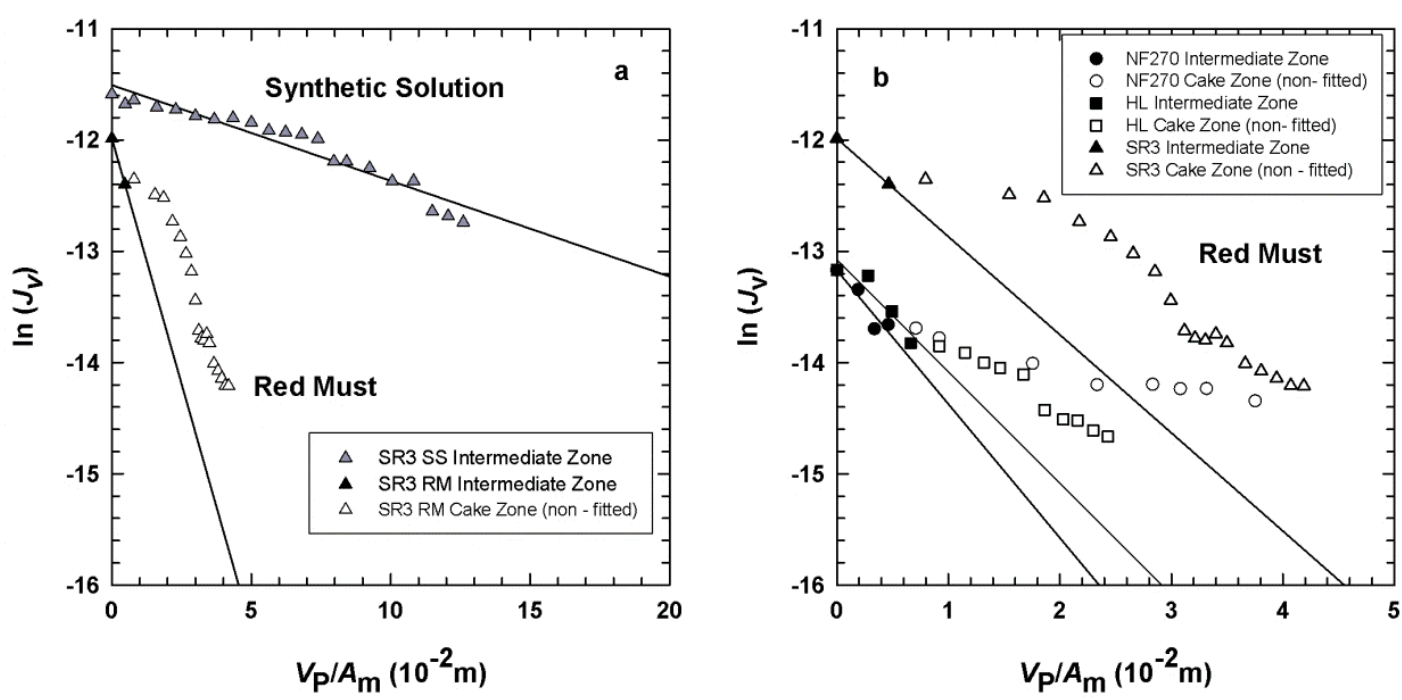

Figure 4.3 $\ln \left(J_{v}\right)$ versus $\left(V_{p} / A_{m}\right)$ : (a) The case of the SR3 membrane for the synthetic solution (SS) and for the red must (RM), (b) The case of the three membranes during red must NF as a comparison. Solid lines represent linear fit to the intermediate blocking mechanism zone of the data, corresponding to Eq. (4).

In Figure 4.3b, the corresponding flux decay for red must filtration is shown for the three membranes studied. The kinetic constants are also shown in Table 4.3. The fastest kinetics corresponds now to NF270 followed by HL and finally by SR3. This agrees with the order of sugars initial retention (compare Figures $4.2 \mathrm{a}$ and $4.2 \mathrm{~b}$ ). What seems reasonable, because more retention would lead to more deposition and consequently to faster flux decay. Note that $\kappa_{i}$ for NF270 was the lowest one (slowest kinetics) for the synthetic solution, while it is the highest (fastest kinetics) when HMW components are present (red must filtration). This increase in $\kappa_{i}$ for the NF270 should be due to a high affinity (chemical or electrostatic) of the membrane material to these 
high molecular weight components. Note too that the less blocked area (less $\kappa_{i}$ ) corresponds to SR3 when HMW compounds are present.

Eq. (5) corresponding to the "cake filtration" mechanism is plotted in Figure 4.4. Here it is clearly seen that, for the three membranes, this mechanism is followed after the initial intermediate blocking during nanofiltration of must. In general, the three membranes suffer little pore blocking, especially SR3, where this mechanism seems to occur only during the first $30 \mathrm{~mL}$ of filtration. It is worth noting that, in the three cases, the cake filtration mechanism seems to be divided into two steps: cake formation and cake formation with compaction. In any case both of the cake fouling steps, are faster for $\mathrm{HL}$ and the corresponding initial $\kappa_{c}$ is relatively low for SR3 while the final $\kappa_{c}$ is lower for NF270 (less compaction). The values of these kinetic constants are shown in Table 4.3.

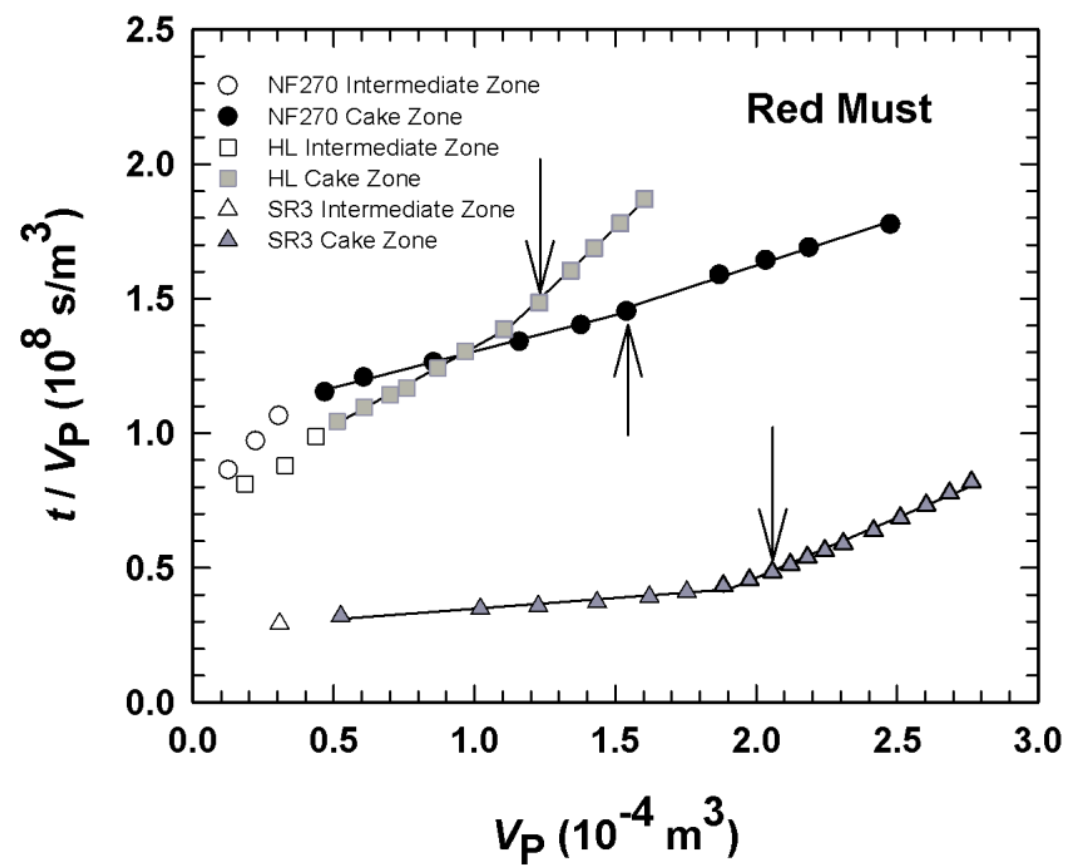

Figure 4.4 $\left(t / V_{p}\right)$ versus $V_{p}$ for each membrane during red must NF. Open symbols correspond to intermediate zone; filled symbols correspond to cake formation mechanism zone.

\subsubsection{Microscopy}

Figure 4.5 provides examples of AFM pictures of an SR3 membrane before fouling (a) and afterwards (b). It seems clear that, after fouling, there is a quite compact thick cake layer that reduces extraordinarily the roughness. 

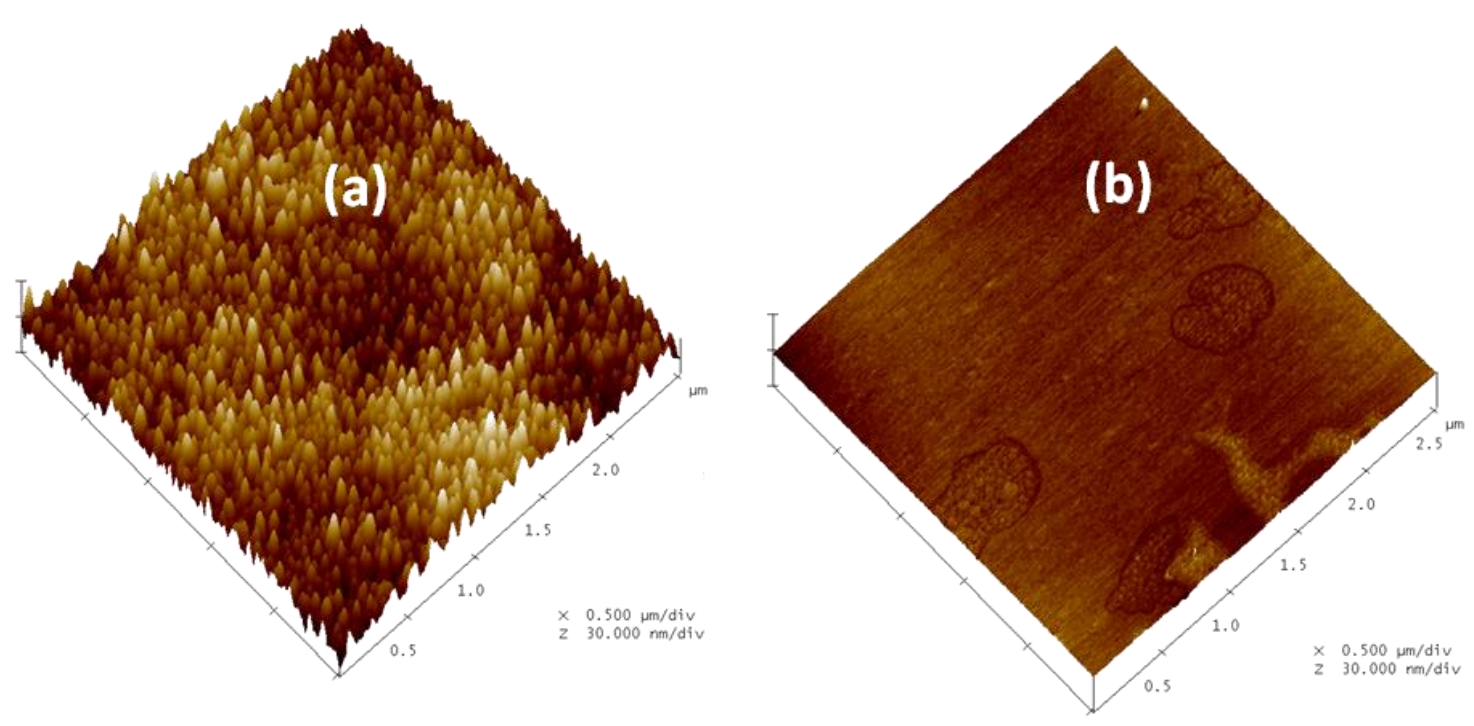

Figure 4.5 AFM pictures of the SR3 membrane before (a) and after (b) fouling. Note that after fouling roughness has decreased substantially.

In Figure 4.6, two SEM pictures of an HL membrane before and after fouling are showed. The two pictures correspond to a $20 \mu \mathrm{m}$ size. Figure $4.6 \mathrm{~b}$ shows a small square area that reveals how the electron beam damaged the cake layer. The same procedure on the clean membrane didn't leave any similar trace (Figure 4.6a).
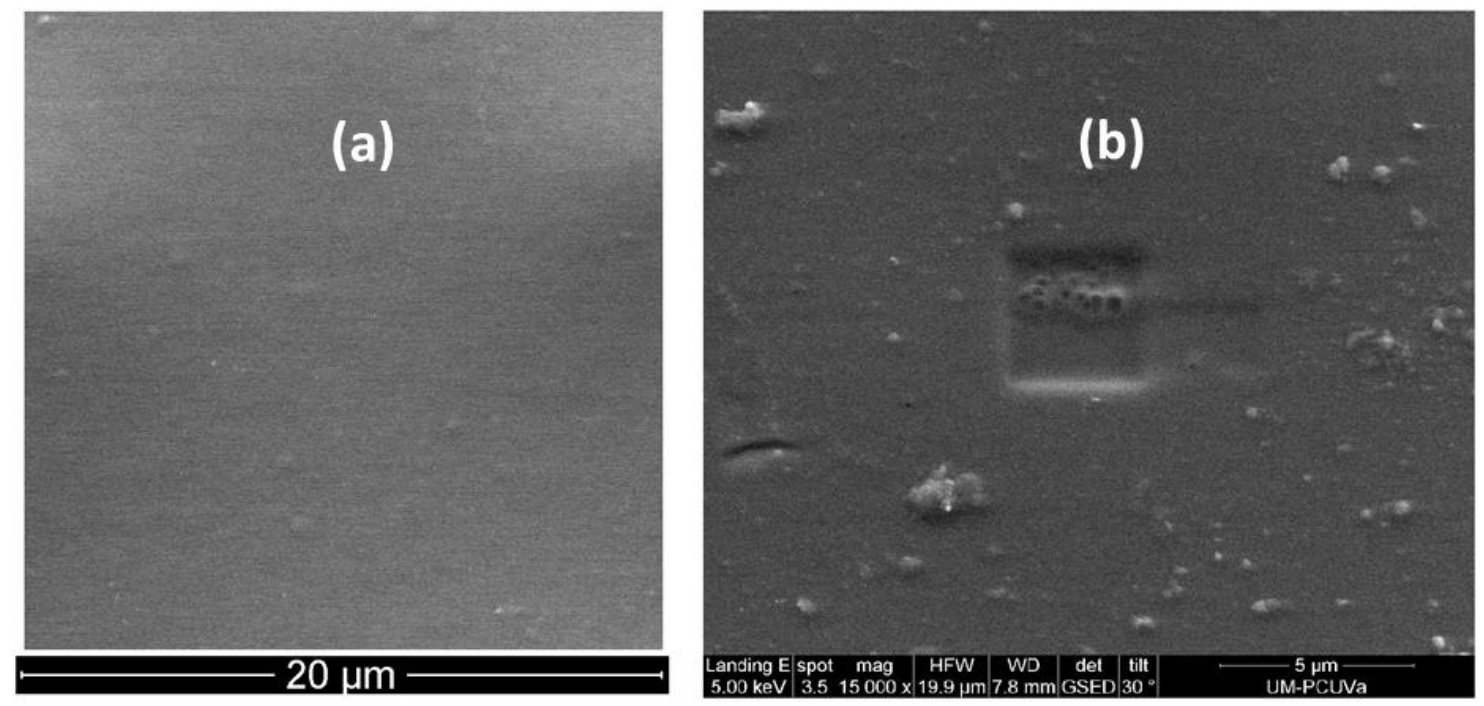

Figure 4.6 SEM pictures of the HL membrane before (a) and after (b) fouling. Note that after fouling a smaller square has been imaged and consequently the deposited layer eroded by the electron beam

\subsubsection{Resistances to the permeate flux.}

The resistances to $J_{v}$ due to the presence of LMW, $R_{f L M W}$, and HMW, $R_{f H M W}$, were determined and analyzed individually. The values of $R_{f L M W}$ for the synthetic 
solution were calculated according to Eq. (1) and (2) with $R_{f H M W}=0$. The kinetics of $R_{f L M W}$ for each membrane during the filtration of the synthetic solution increased with time as observed in previous studies [29]. In this case, NF270 presented the lowest values of resistance due to fouling, followed by $\mathrm{HL}$ and by SR3 (see Figure S4.1a from the supplementary material). This was to be expected because this order appeared also in retention as was shown in Figure 4.2a. Higher retentions lead to increasing viscosity and osmotic pressure that resulted in higher resistance to flux and also to faster fouling according to their corresponding $\kappa_{i}$ in Table 4.3.
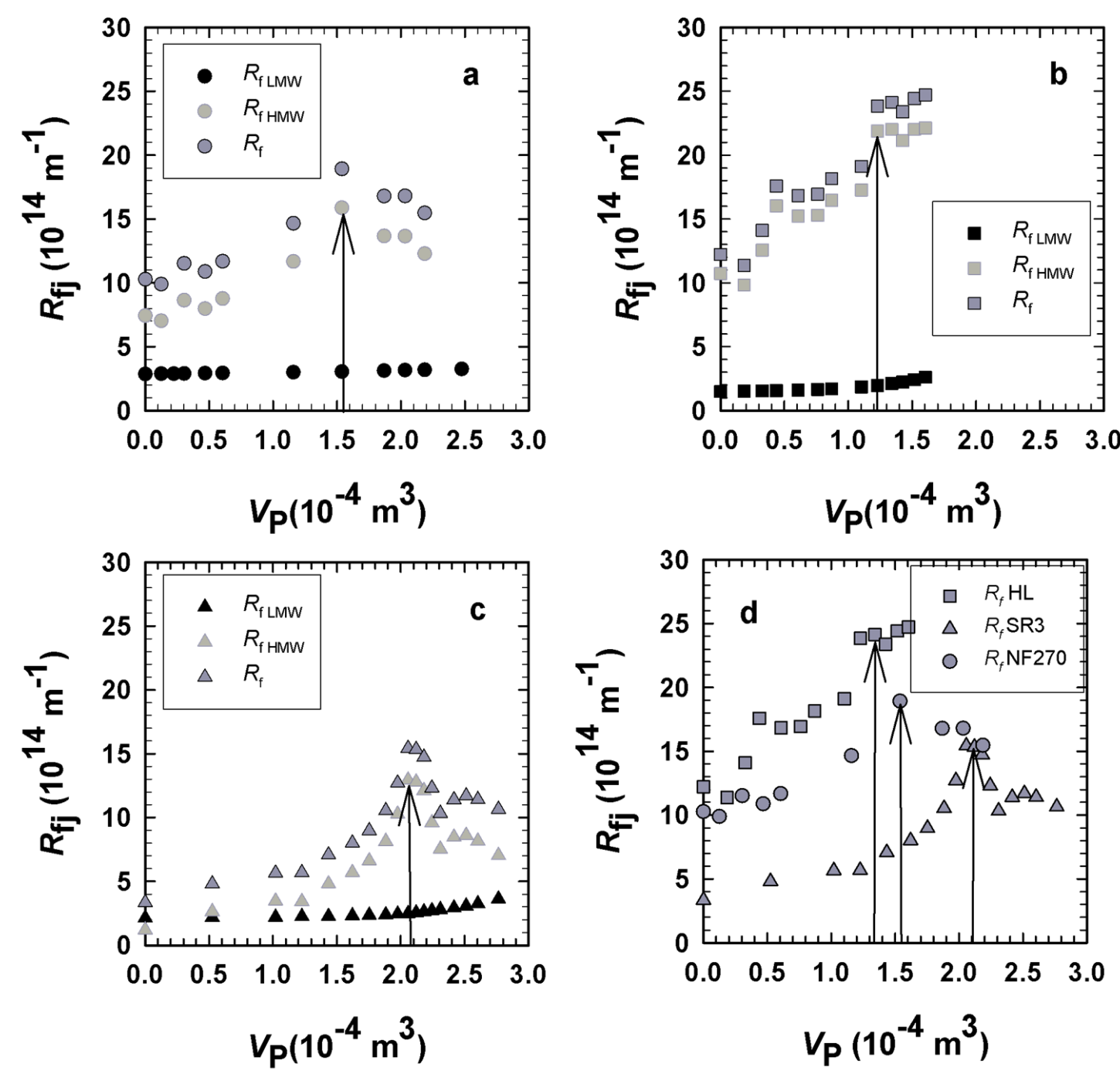

Figure 4.7 Resistance due to fouling by low molecular weight, high molecular weight, and all compounds ( $R_{f L M W}, R_{f H M W}$ and $R_{f}$ respectively) in commercial red must versus the total permeated volume for: (a) NF270, (b) HL and (c) SR3 membranes. (d) Comparison of the total fouling $\left(R_{f}\right)$ resistance for the three membranes. Arrows point to the respective maxima

The correlation between $R_{f L M W}$ and the total sugar concentration (glucose and fructose) on the membrane surfaces, $C_{m T}$ was practically linear (refer to Figure $S 4.1 \mathrm{~b}$ in 
the supplementary material), so it can be concluded that the resistance due to the accumulation of sugars on the membrane surface is proportional to their surface concentration [29].In the case of red must filtrations, the values of $R_{f L M W}$ were determined by the calculation of $C_{m T}$ and the use of the correlation between $R_{f L M W}$ and $C_{m T}$ obtained for the synthetic solution. Replacing $R_{f L M W}$ in Eq. (1), the values of $R_{f H M W}$ were determined for each membrane. Figure 4.7 shows the evolution, with the permeated volume, of the individual resistances due to fouling $\left(R_{f L M W}\right.$ and $\left.R_{f H M W}\right)$ and their addition $\left(R_{f}\right)$ for the three membranes.

The figure shows that during most of the nanofiltration process there is no significant increase of $R_{f L M W}$ as was also the case for the synthetic solution. When filtering red musts, $R_{f L M W}$ remains practically constant in comparison to $R_{f H M W}$ which increases progressively until reaching a maximum beyond which there is a gradual small decrease. This mechanism is clearly followed by SR3 (Figure 4.7c). In all cases, $R_{f H M W}$ has more influence on the $J_{V}$ decrease, but this phenomenon seems to be lower for the SR3 membrane (Figure 4.7d). It is interesting to relate the cake fouling mechanism (Figure 4.4) with the resistances analysis (Figure 4.7).For the three membranes, the maximum $R_{f}$ (or $R_{f H M W}$ ) agrees fairly well with the beginning of the third fouling mechanism, where the cake starts to be compacted.

The specific cake resistance, $\alpha$ (total resistance divided by the mass deposited per unit membrane area) (see Eq. (10)), can help to somehow normalize the resistance to permeate flux due to the fouling generated by all the species present in red must $\left(R_{f}\right)$. As mentioned in section 4.2.4, there are two methods proposed for the estimation of the specific resistance. First, the specific cake resistance was calculated using Eq. (16) with $C_{b}$ evaluated by Eq. (15). For this purpose the numeric derivative of $\left(t / V_{P}\right)$ versus $V_{\mathrm{P}}$ (Figure 4.4) is performed to get $\kappa_{d} / 2$. In this calculation, all the cake formation mechanisms (with and without compaction) were included. This was considered appropriate to describe the evolution of this parameter along the complete filtration. This differs from the methodology applied by Listiarini et al.[7, 27] where a linear regression was performed including only the portion corresponding to the cake filtration without compression. The deposition factor $\gamma$ was estimated for each membrane in order to take into account the incomplete foulant deposition giving the values shown in Table 4.3. Note that $\gamma$ follows the tendency of $\kappa_{c}$ (second step).

In Figure 4.8, the evolution of this theoretical specific cake resistance as a function of the filtered volume is shown for each membrane. It is worth noting, that this parameter shows also a maximum followed by a slight decrease. The arrows correspond to the maximal values of $R_{f}$ for each membrane, which are near the zone of maxima for their specific cake resistance. As expected, the highest a was shown by $\mathrm{HL}$ 
followed by NF270. SR3 presented the lowest values during the first period of filtration (around $175 \mathrm{~mL}$ ) afterwards the resistance increases following the tendencies appearing in $\kappa_{\mathrm{c}}$ (see Figure 4.5). The results obtained for the resistances $\left(R_{f}\right.$ and $\left.\alpha\right)$, and even for the cake formation mechanism, for SR3 explain its different flux decline trend. The less sharp flux decline during the beginning of red must nanofiltration is due to a lower cake formation with a low resistance $\left(R_{f}\right.$ and $\left.\alpha\right)$. But later, the progressive formation and mainly the compaction of the cake cause a flux decay to values close to those for the other two membranes.

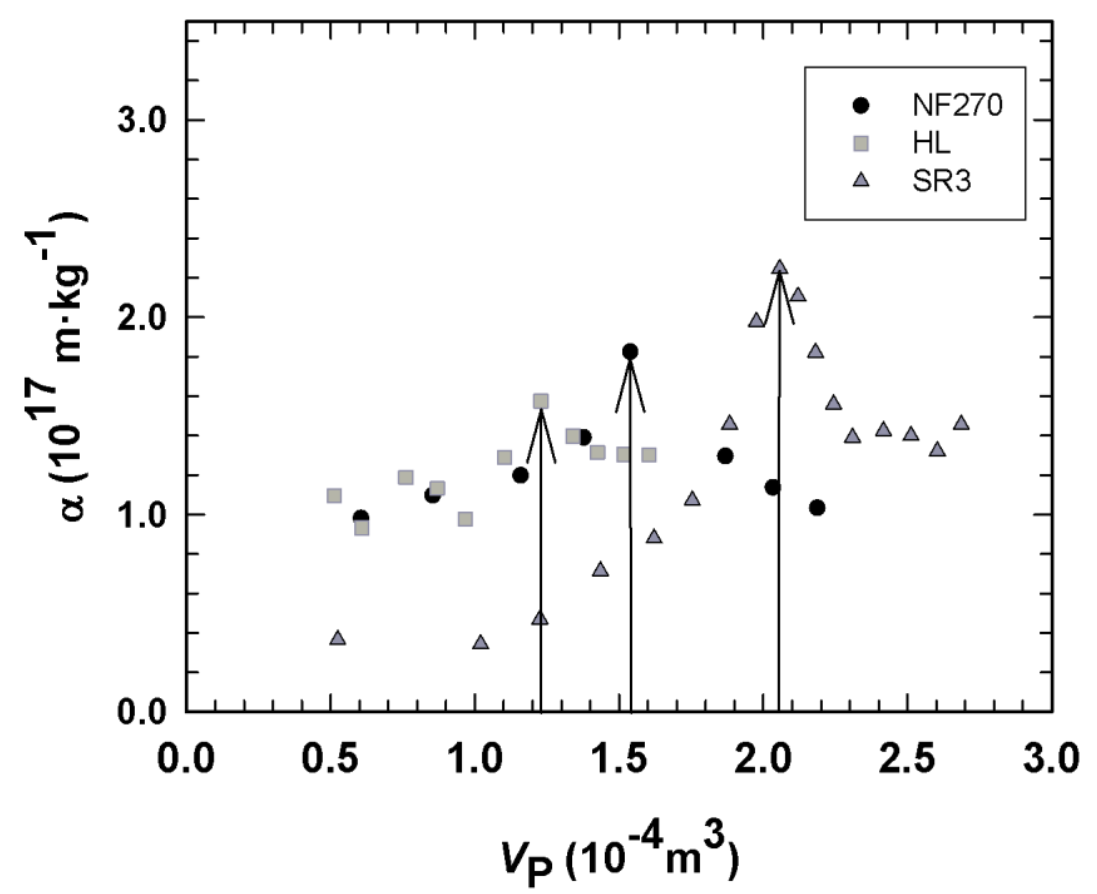

Figure 4.8 Evolution of the specific cake resistance $(\alpha)$ as a function of the permeate volume $\left(\mathrm{V}_{p}\right)$ for the three membranes during red must NF. Arrows correspond to the maximum total fouling resistance for each membrane (according to Figure $4.7 \mathrm{~d}$ ).

A second method was proposed for the estimation of the specific resistance $\alpha$ by using Eq. (20) and the experimental data. In Figure 4.9, the experimental total fouling resistance, in fact evaluated by using Eq. (1) and (5), is compared with that evaluated from the specific resistance $\alpha$ by using Eqs. (10) and (16), for the SR3 membrane. It can be appreciated that the calculated $R_{f}$ follows the same trend as the experimental one. Note that around maximal resistances, the fouling kinetics give values for the resistance which are close to those directly obtained from the HagenPoiseuille equation. For shorter filtration times, fouling kinetics underestimates (while for longer filtration times it overestimates) the total fouling resistance. This can be attributed to the fact that the fouling kinectics predicts a low cake formation and for longer periods the cake mass is over estimated. 
All in all, Figure 4.9 shows that the method proposed for the estimation of $\alpha$ using the fouling kinetics is acceptable since it describes the behavior of the experimental data specially in the period where the cake should be completely formed (before its compaction).

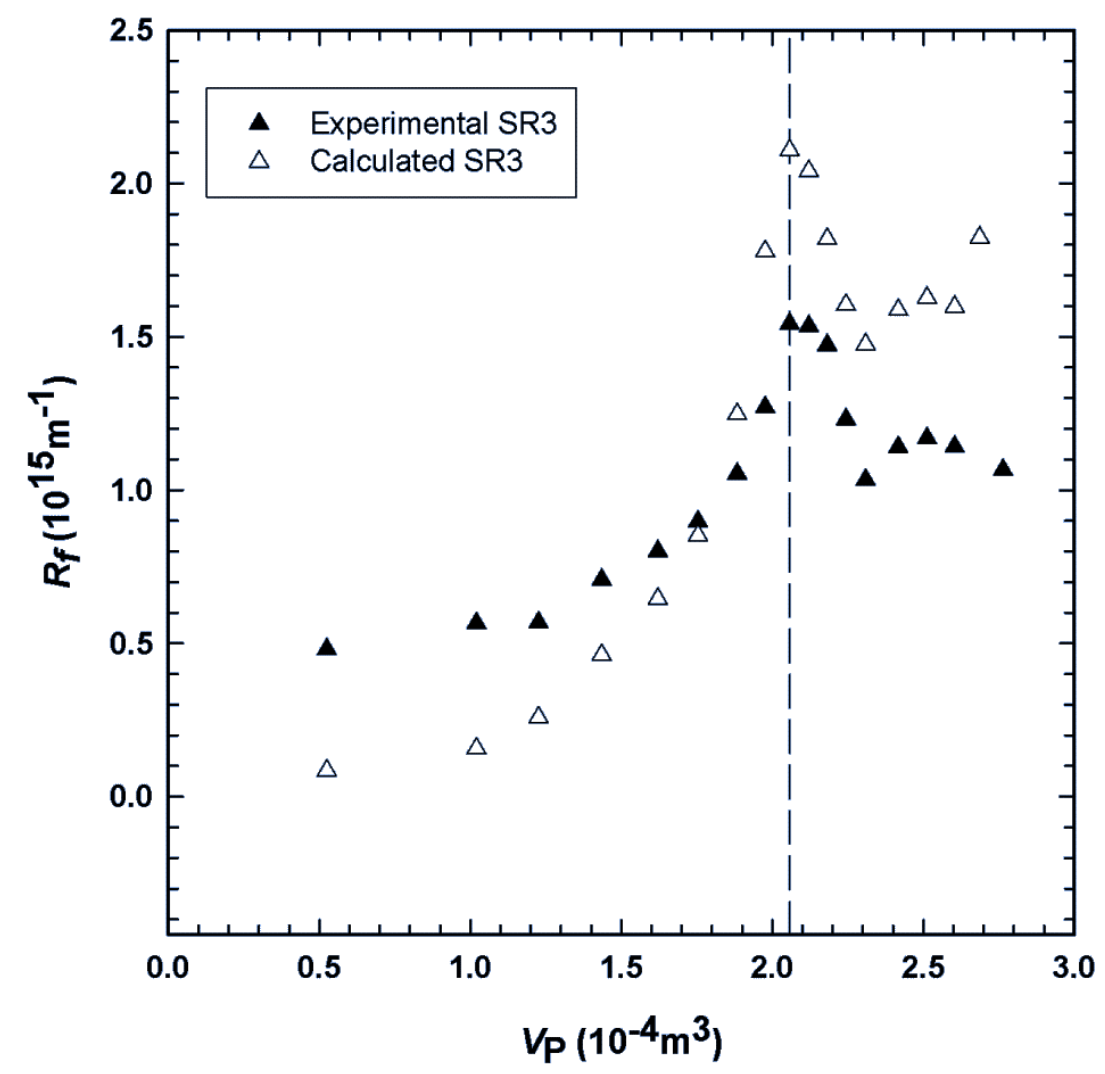

Figure 4.9 Resistance due the total fouling $\left(R_{f}\right)$ for the SR3 membrane. Black triangles show the experimental resistance (see figure $7 \mathrm{~d}$ ) and white triangles refer to the calculated ones.

\subsubsection{Evolution of pore radii}

Pore radii were calculated as the value that minimizes the sum of squared residuals, $\left(R_{\mathrm{cal}}-R_{\mathrm{exp}}\right)^{2}$ for each data set, following the theoretical model explained in section 4.2.5. The fitted dependence between $R$ and $J_{V}$ obtained for the synthetic solution is plotted in Figure 4.10a using grey curves. Here, it can be noticed that the evolution of $R_{i}$ with $J_{v}$ is almost constant. This means that the statement mentioned in section 4.2.3 that data $C_{m, \mathrm{i}}$ coming from the synthetic solution are transportable to must is correct. Evidently, it is worth noting that the model was elaborated for a membrane with a constant average pore size, $r_{p}$; while it seems clear that in our case the effective mean pore size should change during the process of filtration due to the corresponding fouling process that includes pore blocking. Thus, the gray lines in Figure $4.10 \mathrm{a}$ correspond to the mean pore size of the membrane during the filtration process. 

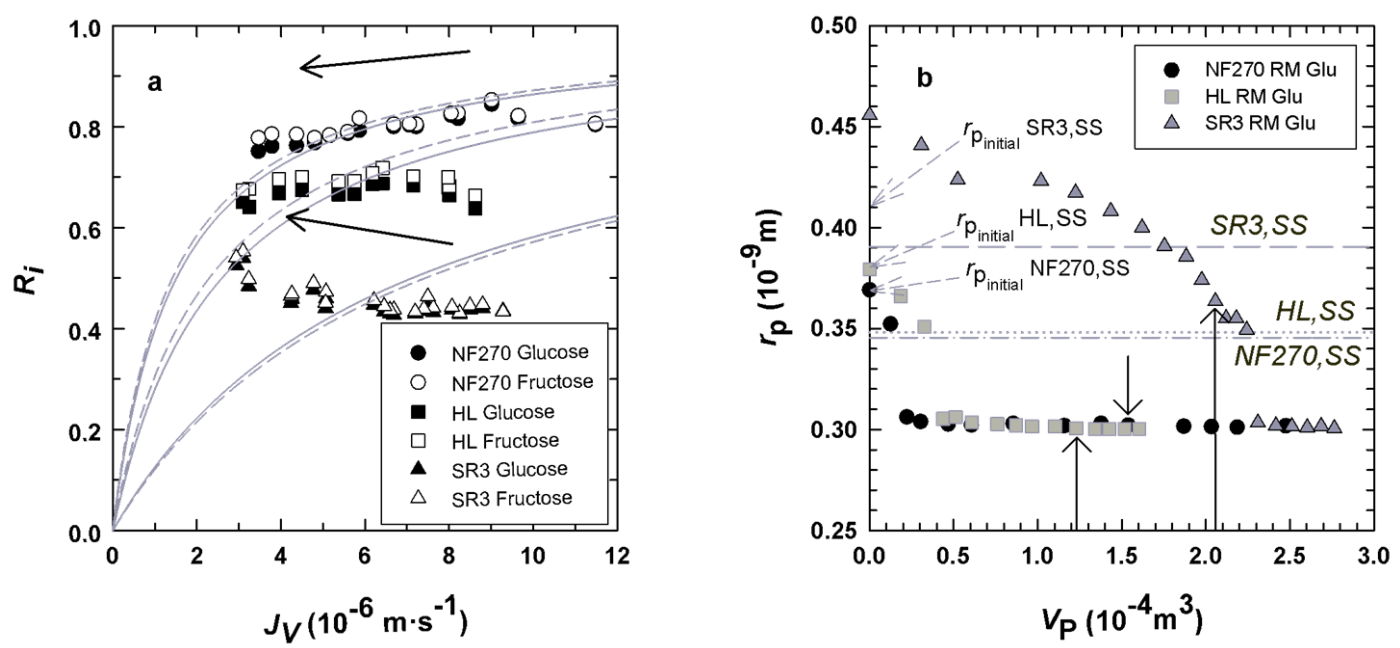

Figure 4.10 (a) Retention versus $J_{V}$ for the synthetic solution filtration. Gray lines are the fits using theoretical model for pore radius calculation (solid for Glucose, dashed for fructose). Arrows indicate time line. (b.)-Time evolution of pore radii calculated for each single data point of - NF270 (Glu), $\mathbf{H L}(\mathrm{Glu}), \boldsymbol{\Delta}$ SR3 (Glu) of the red must NF process. Horizontal lines represent the average values obtained for the synthetic solution NF along the complete process. Dashed grey arrows show the initial pore radii obtained for the synthetic solution. Black arrows correspond to the maximum total fouling resistance for each membrane (according to Figure $4.7 \mathrm{~d})$.

During the permeation of must, there is a continuous increase of retention while flow decreases slowly. The progressive increase of retention is so high that it seems inappropriate to assume a single pore size. In this case the model has been applied to each measurement and the pore radius obtained as a function of the permeated volume. In Figure $4.10 \mathrm{~b}$, the effective pore radii evaluated from red must retention experiments are shown. It can be seen that there is a clear reduction of the effective pore size of the membrane (much slower, although a little larger, for the SR3 membrane). The mean pore radii for the synthetic solution are also shown here by horizontal lines. It is important to mention that the initial values obtained for grape must are higher than the average pore radii obtained for the synthetic solution. This agrees with the assessment of sugar retention by comparing Figure $4.2 \mathrm{a}$ and $4.2 \mathrm{~b}$ in section 4.4.2. Average values for the synthetic solution are shown in Figure 4.9b for the sake of comparison, but in fact these values decrease with filtration time due to membrane fouling (intermediate blocking) previously mentioned. Moreover, comparing the initial values obtained for the synthetic solution (refer to dashed arrows in Figure 4.10b) with those corresponding to must, it can be seen that for HL and NF270 they are almost equal. However in the case of SR3 it is still higher for must. This larger pore size causes that more sugar molecules are able to enter the porous matrix blocking larger pores very quickly (in the first moments of the process). This occurs faster in the model solution than in must (due to the lower effective pressure and less flow in the case of 
must), so, apparently, during the initial moments the membrane fouled with must presents greater pore sizes.

It is clearly observed that SR3 has the biggest pore radii, while the smallest ones appear in NF270. It can also be seen that the final pore radii for all the membranes are around $0.3 \mathrm{~nm}$. This fact indicates that effective radius is determined mainly by the cake formed on the membrane, more than by the membrane itself.

In spite of the final convergence in equivalent pore radii, initial details do show differences between the membranes, especially between SR3 and the other two. Figure $4.10 \mathrm{~b}$ shows a clear and pronounced drop of pore radii during the very first filtration moments for NF270 and HL. This happens as a consequence of the pore blocking explained in previous paragraphs. In contrast, for SR3, the pore radius does not show any significant initial decrease.

It appears clear that, for $\mathrm{HL}$ and NF270, pore blocking is the main factor determining the effective pore size with a final smooth additional reduction of pore size caused by the formation of the cake. The SR3 membrane is only slightly influenced by pore blocking with a final deep reduction due to the cake deposit and its compaction.

Vertical solid line arrows in Figure 4.10b correspond to the maximal resistances (Figure 4.7). Thus, it seems clear that maximal resistance occurs when the trend of decrease in pore size due to the cake formation starts to stabilize. This is especially apparent for the SR3 membrane.

\subsubsection{Pressure drops}

Figure 4.11 shows the evolution of osmotic pressures and total effective pressures through: the global membrane system, the membrane and the cake itself.

Referring to the osmotic pressure (Figure 4.11a), it increases for the cake and the global membrane system (that seems to be controlled by the cake) and decrease for the membrane itself with time (permeated volume). Note that the maximum rate of change for all the osmotic pressure terms appear when the fouling resistance $R_{f}$ has its maximum (dashed lines in Figure 4.11). Below this maximum there are negative osmotic pressures for the cake which means that concentration is higher at the cakemembrane interface than at the feed-cake interface. After the maximum in resistance, all the interfaces from retentate to permeate (i.e. system and cake) correspond to positive concentration gradients.

It seems clear (see Figure $4.11 \mathrm{~b}$ ) that the effective pressure drop through all the components of the membrane system and through the global system decrease with time (permeated volume) and that the maximal fouling resistance appears when these 
pressure drops decrease faster. It seems also clear that most of the effective pressure drop happens through the cake.
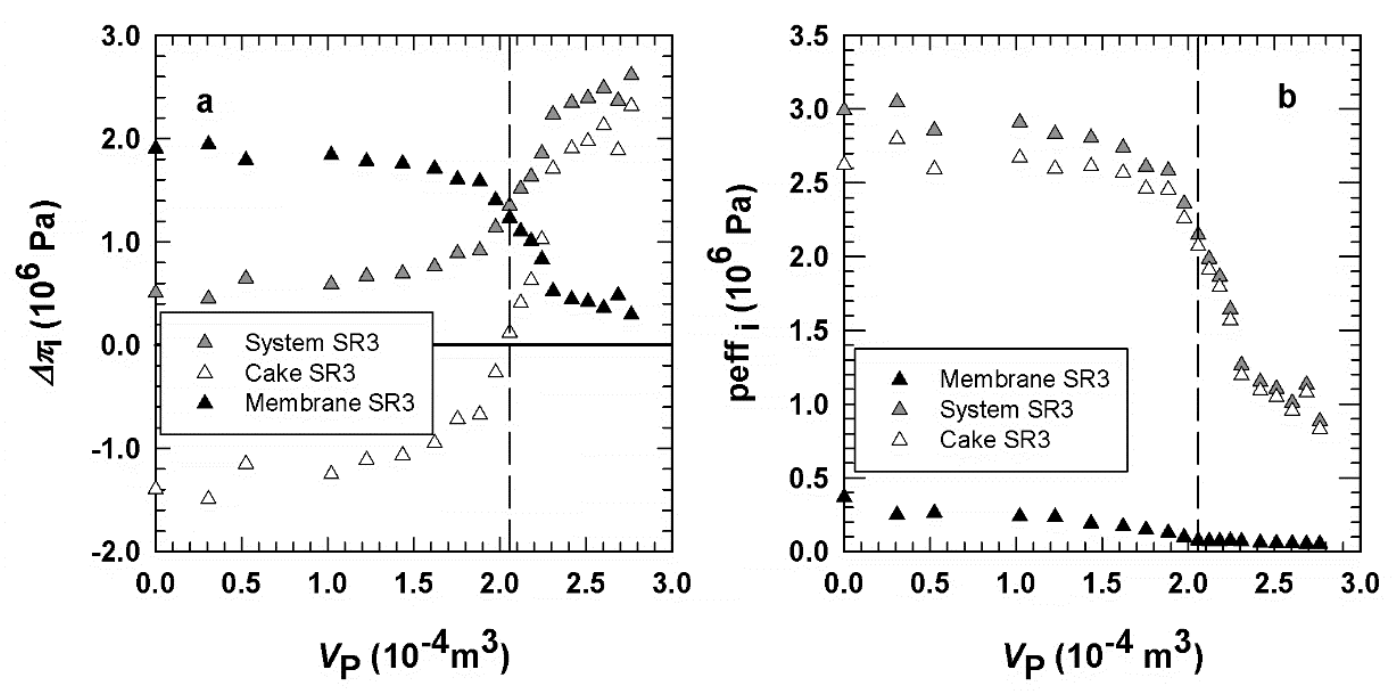

Figure 4.11 Osmotic pressures (a) and effective total pressures (b) through the membrane, cake and membrane system (membrane plus cake) for the SR3 membrane.

It can be concluded that, in our case, the maximum in the fouling resistance and the appearance of a change in cake kinetics occur when the osmotic pressures reduce substantially and quickly the effective pressure. Regarding the passage from negative to positive osmotic pressures for the cake this would happen when the cake is completely build due to compression followed by a gradual (slower) compaction with an increase of the concentration at the bulk-cake interface $\left(C_{\mathrm{m}}\right)$.

Note that, for the three membranes, when the osmotic pressure of the system starts to increase, sugars are retained at their maxima by the membrane system, as can be seen in Figure 4.2b. The highest $R_{f H M W}, R_{f L M W}$ and $R_{f}$ correspond to the beginning of the high retention plateau. This is especially clear for the SR3 membrane. So, as already mentioned, the sugar retention increase can be attributed to the formation of a cake layer on the membrane surface but its compression (and the corresponding osmotic pressure increase through the cake and subsequently through the membrane system) may be the cause of the significant retention increase that stops increasing when cake is completely built.

\subsection{Conclusions}

We have systematically studied the fouling mechanism and resistances and their influence on the performance of three different NF membranes proposed for sugar 
control of grape must. Moreover, a method was proposed for the analysis of the different osmotic pressure gradients through the resistances of the membrane system.

The fouling kinetics when high molecular weight compounds are present consists in three consecutive steps: An initial pore blocking step followed by a cake deposition phase and an increase in compression until arriving to compaction giving a slower kinetics. When the cake is completely well assembled, the sugar retention has arrived to the maximum and osmotic pressure of the system increases causing a reduction of the effective pressure. This later causes a decrease of cake resistance that was increasing until this moment. The evolution of retention and the effective pore size reveals the convergence of the effective pore size to that of the cake after compaction.

Moreover, when the cake is completely built, its compaction promotes an increase of the concentration at the feed-cake interface causing a passage from negative to positive osmotic pressures for the cake.

The analysis of the flux decay and retention of sugar in musts shows that, two of the three membranes studied, HL and SR3 are appropriate to reduce the content of sugar of red must. Specifically SR3 shows the best passage of sugar and less fouling.

\subsection{Acknowledgements}

Authors would like to thank the "Ministerio de Ciencia e Innovación (MCINN)" for the financial support of this work within the frame of the "Plan Nacional de I+D+I" through the research projects CTQ2012-31076 and MAT2011-25513. Also the Spanish "Junta de Castilla y Leon" has contributed through the project VA248U13.

C. Salgado wants to thank the Spanish Ministry of Education for the grant they gave her within the frame of the "Plan Nacional de Investigación Científica, Desarrollo e InnovaciónTecnológica 2008-2011" (FPU grant: AP2010-5769) to complete her PhD.

Authors acknowledge Dow-Filmtec for the free supply of membrane flat sheet samples to conduct this research. 


\subsection{Nomenclature}

Roman

\begin{tabular}{|c|c|}
\hline$A_{m}$ & Membrane surface area $\left(\mathrm{m}^{2}\right)$ \\
\hline$A_{k}$ & Membrane porosity \\
\hline $\mathrm{C}_{0, \mathrm{i}}$ & Feed concentration of the i-th component $\left(\mathrm{kg} \mathrm{m}^{-3}\right)$ \\
\hline $\mathrm{C}_{\mathrm{b}}$ & Bulk concentration of foulants $\left(\mathrm{kg} \mathrm{m}^{-3}\right)$ \\
\hline $\mathrm{C}_{\mathrm{f}, \mathrm{i}}$ & Feed concentration of the i-th component $\left(\mathrm{kg} \mathrm{m}^{-3}\right)$ \\
\hline $\mathrm{C}_{\mathrm{DE}}$ & Total dry extract of must $\left(\mathrm{kg} \mathrm{m}^{-3}\right)$ \\
\hline $\mathrm{C}_{\mathrm{HMW}}$ & Concentration of $\mathrm{HMW}\left(\mathrm{kg} \mathrm{m}^{-3}\right)$ \\
\hline $\mathrm{C}_{\mathrm{m}, \mathrm{i}}$ & $\begin{array}{l}\text { Concentration of the i-th component on the bulk-cake interface } \\
\text { (membrane active layer) }\left(\mathrm{kg} \mathrm{m}^{-3}\right)\end{array}$ \\
\hline $\mathrm{C}_{\mathrm{m}, \mathrm{i}}^{\prime}$ & $\begin{array}{l}\text { Concentration of the i-th component on the membrane-cake } \\
\text { interface }\left(\mathrm{kg} \mathrm{m}^{-3}\right)\end{array}$ \\
\hline $\mathrm{C}_{\mathrm{mT}}$ & Total sugar concentration on the membrane active layer $\left(\mathrm{kg} \mathrm{m}^{-3}\right)$ \\
\hline $\mathrm{C}_{\mathrm{p}, \mathrm{i}}$ & Permeate concentration of the i-th component $\left(\mathrm{kg} \mathrm{m}^{-3}\right)$ \\
\hline $\mathrm{C}_{\mathrm{T}, 0}$ & $\begin{array}{l}\text { Initial total sugar concentration (glucose and fructose) of red must } \\
\left(\mathrm{kg} \mathrm{m}^{-3}\right)\end{array}$ \\
\hline$D_{i}$ & Diffusion coefficient of the i-th component $\left(\mathrm{m}^{2} \mathrm{~s}^{-1}\right)$ \\
\hline HMW & High molecular weight compounds \\
\hline$J_{v}$ & Permeate flux per unit of area through the membrane $\left(\mathrm{m}^{3} \mathrm{~m}^{-2} \mathrm{~s}^{-1}\right)$ \\
\hline$J_{\mathrm{v}, 0}$ & $\begin{array}{l}\text { Permeate flux per unit of area through the membrane at time } t=0 \\
\left(\mathrm{~m}^{3} \mathrm{~m}^{-2} \mathrm{~s}^{-1}\right)\end{array}$ \\
\hline $\mathrm{K}_{\mathrm{c}}$ & Hindrance factor for convection given by Eq. (25) \\
\hline $\mathrm{K}_{\mathrm{d}}$ & Hindrance factor for diffusion given by Eq. (26) \\
\hline $\mathrm{K}_{\mathrm{m}, \mathrm{i}}$ & $\begin{array}{l}\text { Mass transfer coefficient of the } \mathrm{i} \text {-th component at semipermeable } \\
\text { membranes }\left(\mathrm{m} \mathrm{s}^{-1}\right)\end{array}$ \\
\hline LMW & Low molecular weight compounds \\
\hline$L_{p}$ & Water permeability $\left(\mathrm{m} \mathrm{Pa}^{-1} \mathrm{~s}^{-1}\right)$ \\
\hline $\mathrm{m}_{\mathrm{c}}$ & Mass of cake deposited on the membrane surface in $(\mathrm{kg})$ \\
\hline $\mathrm{m}_{\text {HMW }}$ & Mass of HMW in the retentate $(\mathrm{kg})$ \\
\hline $\mathrm{M}_{\mathrm{i}}$ & Molar weight of the i-th component $\left(\mathrm{kg} \mathrm{mol}^{-1}\right)$ \\
\hline $\mathrm{m}_{\mathrm{TR}}(\mathrm{t})$ & Total sugar content of the retentate at the filtration time $\mathrm{t}(\mathrm{kg})$ \\
\hline $\mathrm{Pe}$ & Peclet number \\
\hline $\mathrm{R}$ & ideal gas constant $\left(1.987 \cdot 10^{-3} \mathrm{kcal} \mathrm{mol}^{-1} \mathrm{~K}^{-1}\right)$ \\
\hline $\mathrm{R}_{\mathrm{fHMW}}$ & $\begin{array}{l}\text { Resistance due to fouling by high molecular weight compounds } \\
\left(\mathrm{m}^{-1}\right)\end{array}$ \\
\hline
\end{tabular}




\begin{tabular}{|c|c|}
\hline $\mathrm{R}_{\mathrm{fLMW}}$ & $\begin{array}{l}\text { Resistance due to fouling by low molecular weight compounds } \\
\left(\mathrm{m}^{-1}\right)\end{array}$ \\
\hline$R_{f j}$ & General resistance due to fouling $\left(\mathrm{m}^{-1}\right)$ \\
\hline$R_{f}$ & Total resistance due to fouling $\left(\mathrm{m}^{-1}\right)$ \\
\hline $\mathrm{R}_{\mathrm{i}}$ & Membranes true retention for the i-th component \\
\hline $\mathrm{R}_{\mathrm{m}}$ & Membrane resistance $\left(\mathrm{m}^{-1}\right)$ \\
\hline$r_{p}$ & Pore radii $(\mathrm{nm})$ \\
\hline$r_{i}$ & Radii of the $\mathrm{i}$-th component $(\mathrm{nm})$ \\
\hline $\mathrm{T}$ & Absolute temperature $(\mathrm{K})$ \\
\hline $\mathrm{t}$ & Filtration time \\
\hline $\mathrm{V}_{0}$ & Initial volume of grape must $\left(\mathrm{m}^{3}\right)$ \\
\hline$V_{p}$ & Permeate volume $\left(\mathrm{m}^{3}\right)$ \\
\hline$V_{R}(t)$ & Volume of the retentate at the filtration time $t\left(\mathrm{~m}^{3}\right)$ \\
\hline \multicolumn{2}{|l|}{ Greek } \\
\hline$\alpha$ & Specific cake resistance $\left(\mathrm{m} \mathrm{kg}^{-1}\right)$ \\
\hline$\gamma$ & Deposition factor on the membrane surface \\
\hline$\Delta \mathrm{p}_{\mathrm{h}, \mathrm{s}}$ & Applied transmembrane pressure $(\mathrm{Pa})$ \\
\hline$\Delta p_{\text {eff,c }}$ & Effective pressure drop across the cake $(\mathrm{Pa})$ \\
\hline$\Delta \mathrm{p}_{\mathrm{eff}, \mathrm{m}}$ & Effective pressure drop across the membrane $(\mathrm{Pa})$ \\
\hline$\Delta \mathrm{p}_{\mathrm{eff}, \mathrm{s}}$ & Effective pressure drop across the system $(\mathrm{Pa})$ \\
\hline$\Delta \mathrm{p}_{\mathrm{h}, \mathrm{c}}$ & Hydraulic Pressure drop across the cake $(\mathrm{Pa})$ \\
\hline$\Delta \mathrm{p}_{\mathrm{h}, \mathrm{m}}$ & Hydraulic Pressure drop across the membrane $(\mathrm{Pa})$ \\
\hline$\Delta x$ & Membrane thickness $(\mathrm{m})$ \\
\hline$\Delta \pi_{\mathrm{c}}$ & Osmotic pressure gradient across the cake-active la \\
\hline
\end{tabular}
(Pa)

$\Delta \pi_{\mathrm{m}} \quad$ Osmotic pressure gradient across the membrane-cake interface (Pa)

$\Delta \pi_{\mathrm{s}} \quad$ Osmotic pressure gradient across the membrane system $(\mathrm{Pa})$

$\eta_{\mathrm{p}} \quad$ Viscosity inside the membrane pore (Pa s)

$\kappa_{\mathrm{c}} \quad$ Kinetic constant for the cake model $\left(\mathrm{s} \mathrm{m}^{-6}\right)$

$\kappa_{i} \quad$ Kinetic constant for the intermediate blocking model $\left(\mathrm{m}^{-1}\right)$

$\lambda \quad$ Ratio $r_{i} / r_{\mathrm{p}}$

$\phi \quad$ Steric partition coefficient 


\subsection{References}

[1] A. Giacobbo, A.M. Bernardes, M.N.d. Pinho, Nanofiltration for the Recovery of Low Molecular Weight Polysaccharides and Polyphenols from Winery Effluents, Separation Science and Technology, 48 (2013) 2524-2530.

[2] J. Warczok, M. Ferrando, F. López, C. Güell, Concentration of apple and pear juices by nanofiltration at low pressures, Journal of Food Engineering, 63 (2004) 63-70

[3] I. Kiss, G. Vatai, E. Bekassy-Molnar, Must concentrate using membrane technology, Desalination, 162 (2004) 295-300.

[4] A. Versari, R. Ferrarini, G.P. Parpinello, S. Galassi, Concentration of Grape Must by Nanofiltration Membranes, Food and Bioproducts Processing, 81 (2003) 275-278.

[5] N. García-Martín, S. Perez-Magariño, M. Ortega-Heras, C. González-Huerta, M. Minnea, M.L. González-Sanjosé, L. Palacio, P. Prádanos, A. Hernández, Sugar reduction in musts with nanofiltration membranes to obtain low alcohol-content wines, Separation and Purification Technology, 76 (2010) 158-170.

[6] N. Garcia-Martin, S. Perez-Magarino, M. Ortega-Heras, C. Gonzalez-Huerta, M. Mihnea, M.L. Gonzalez-Sanjose, L. Palacio, P. Pradanos, A. Hernandez, Sugar reduction in white and red musts with nanofiltration membranes, Desalination and water treatment, 27 (2011) 167-174.

[7] K. Listiarini, W. Chun, D.D. Sun, J.O. Leckie, Fouling mechanism and resistance analyses of systems containing sodium alginate, calcium, alum and their combination in dead-end fouling of nanofiltration membranes, Journal of Membrane Science, 344 (2009) 244-251.

[8] D.C. Sioutopoulos, A.J. Karabelas, S.G. Yiantsios, Organic fouling of RO membranes: Investigating the correlation of $\mathrm{RO}$ and UF fouling resistances for predictive purposes, Desalination, 261 (2010) 272-283.

[9] B.F. Ruth, Studies in Filtration III. Derivation of General Filtration Equations, Industrial \& Engineering Chemistry, 27 (1935) 708-723.

[10] C.O. M J Matteson, Filtration: Principles and Practices, Second Edition, Revised and Expanded, Marcel Dekker, New York, 1987.

[11] F.M. Tiller, The role of porosity in filtration part 3: Variable-pressure-variable-rate filtration, AIChE Journal, 4 (1958) 170-174.

[12] F.M. Tiller, The role of porosity in filtration. Numerical methods for constant rate and constant pressure filtration based on Kozeny's law, Chem. Eng. Prog., 49 (1953) 467-479.

[13] F.M. Tiller, The role of porosity in filtration. Part 2. Analytical equations for constant rate filtration, Chem. Eng. Prog., 51 (1955) 282-290. 
[14] F.M. Tiller, H.R. Cooper, The role of porosity in filtration: IV. Constant pressure filtration, AIChE J., 6 (1960) 595-601.

[15] C. Tien, R. Bai, An assessment of the conventional cake filtration theory, Chemical Engineering Science, 58 (2003) 1323-1336.

[16] E. Vorobiev, Derivation of filtration equations incorporating the effect of pressure redistribution on the cake-medium interface: A constant pressure filtration, Chemical Engineering Science, 61 (2006) 3686-3697.

[17] M. Ferrando, A. Rǒżek, M. Zator, F. López, C. Güell, An approach to membrane fouling characterization by confocal scanning laser microscopy, Journal of Membrane Science, 250 (2005) 283-293.

[18] K.O. Ndukaife, J.C. Ndukaife, A.G. Agwu Nnanna, Membrane fouling characterization by infrared thermography, Infrared Physics \& Technology, 68 (2015) 186-192.

[19] Y. Lanteri, P. Fievet, C. Magnenet, S. Déon, A. Szymczyk, Electrokinetic characterisation of particle deposits from streaming potential coupled with permeate flux measurements during dead-end filtration, Journal of Membrane Science, 378 (2011) 224-232.

[20] P.H. Hermans, H.L. Bredee, Zur kenntnis der filtrationsgesetze, Rec. Trav. Chim., 54 (1935) 680-700.

[21] V.E. Gonsalves, A critical investigation on the viscose filtration process, Recueil des Travaux Chimiques des Pays-Bas, 69 (1950) 873-903.

[22] H.P. Grace, Structure and performance of filter media. I. The internal structure of filter media, AIChE Journal, 2 (1956) 307-315.

[23] M. Shirato, T. Aragaki, E. Iritani, Blocking filtration laws for filtration of power-law non-Newtonian fluids, J. Chem. Eng. Japan, 12 (1979) 162-164.

[24] W.R. Bowen, J.I. Calvo, A. Hernández, Steps of membrane blocking in flux decline during protein microfiltration, Journal of Membrane Science, 101 (1995) 153-165

[25] C. Herrero, P. Prádanos, J.I. Calvo, F. Tejerina, A. Hernández, Flux Decline in Protein Microfiltration: Influence of Operative Parameters, Journal of Colloid and Interface Science, 187 (1997) 344-351.

[26] J.C. Schippers, J. Verdouw, The modified fouling index, a method of determining the fouling characteristics of water, Desalination, 32 (1980) 137-148.

[27] K. Listiarini, D.D. Sun, J.O. Leckie, Organic fouling of nanofiltration membranes: Evaluating the effects of humic acid, calcium, alum coagulant and their combinations on the specific cake resistance, Journal of Membrane Science, 332 (2009) 56-62.

[28] C.H. Koo, A.W. Mohammad, F. Suja, M.Z. Meor Talib, Setting-up of modified fouling index (MFI) and crossflow sampler-modified fouling index (CFS-MFI) 
measurement devices for NF/RO fouling, Journal of Membrane Science, 435 (2013) 165-175.

[29] C. Salgado, L. Palacio, F.J. Carmona, A. Hernández, P. Prádanos, Influence of low and high molecular weight compounds on the permeate flux decline in nanofiltration of red grape must, Desalination, 315 (2013) 124-134.

[30] A.A. Kozinski, E.N. Lightfoot, Ultrafiltration of proteins in stagnation flow, AIChE Journal, 17 (1971) 81-85.

[31] R.L. Goldsmith, Macromolecular Ultrafiltration with Microporous Membranes, Industrial \& Engineering Chemistry Fundamentals, 10 (1971) 113-120.

[32] G. Jonsson, Boundary layer phenomena during ultrafiltration of dextran and whey protein solutions, Desalination, 51 (1984) 61-77.

[33] J.G. Wijmans, S. Nakao, C.A. Smolders, Flux limitation in ultrafiltration: Osmotic pressure model and gel layer model, Journal of Membrane Science, 20 (1984) 115-124 [34] L. Ding, M.Y. Jaffrin, Benefits of High Shear Rate Dynamic Nanofiltration and Reverse Osmosis: A Review, Separation Science and Technology, 49 (2014) 19531967.

[35] R.C. Kuhn, F. Maugeri Filho, V. Silva, L. Palacio, A. Hernández, P. Prádanos, Mass transfer and transport during purification of fructooligosaccharides by nanofiltration, Journal of Membrane Science, 365 (2010) 356-365.

[36] P. Prádanos, J.I. Arribas, A. Hernández, Retention of proteins in cross-flow UF through asymmetric inorganic membranes, AIChE Journal, 40 (1994) 1901-1910.

[37] P. Pradanos, J.I. Arribas, A. Hernandez, Hydraulic Permeability, Mass Transfer, and Retention of PEGs in Cross-flow Ultrafiltration through a Symmetric Microporous Membrane, Separation Science and Technology, 27 (1992) 2121-2142.

[38] P. Prádanos, Estudio y Caracterización de Membranas de Ultrafiltración. Su aplicación a Procesos de Interés Enológico, PhD Thesis, Secretariado de Publicaciones de la Universidad de Valladolid, ISBN 84-7762-524-7, Valladolid, (1994). [39] D.C. Sioutopoulos, S.G. Yiantsios, A.J. Karabelas, Relation between fouling characteristics of $\mathrm{RO}$ and UF membranes in experiments with colloidal organic and inorganic species, Journal of Membrane Science, 350 (2010) 62-82.

[40] OIV, Compendium of International Methods of Wine and Must Analysis, OIV, Paris, 2011.

[41] V. Silva, P. Prádanos, L. Palacio, J.I. Calvo, A. Hernández, Relevance of hindrance factors and hydrodynamic pressure gradient in the modelization of the transport of neutral solutes across nanofiltration membranes, Chemical Engineering Journal, 149 (2009) 78-86. 
[42] P. Dechadilok, W.M. Deen, Hindrance Factors for Diffusion and Convection in Pores, Industrial \& Engineering Chemistry Research, 45 (2006) 6953-6959

[43] K. Wesolowska, S. Koter, M. Bodzek, Modelling of nanofiltration in softening water, Desalination, 162 (2004) 137-151.

[44] J.-H. Choi, K. Fukushi, K. Yamamoto, A study on the removal of organic acids from wastewaters using nanofiltration membranes, Separation and Purification Technology, 59 (2008) 17-25.

[45] M. Mänttäri, T. Pekuri, M. Nyström, NF270, a new membrane having promising characteristics and being suitable for treatment of dilute effluents from the paper industry, Journal of Membrane Science, 242 (2004) 107-116.

[46] C.Y. Tang, Y.-N. Kwon, J.O. Leckie, Effect of membrane chemistry and coating layer on physiochemical properties of thin film composite polyamide $\mathrm{RO}$ and NF membranes: II. Membrane physiochemical properties and their dependence on polyamide and coating layers, Desalination, 242 (2009) 168-182.

[47] G. Rice, A.R. Barber, A.J. O'Connor, A. Pihlajamaki, M. Nystrom, G.W. Stevens, S.E. Kentish, The influence of dairy salts on nanofiltration membrane charge, Journal of Food Engineering, 107 (2011) 164-172.

[48] K. Singh, S. Devi, H.C. Bajaj, P. Ingole, J. Choudhari, H. Bhrambhatt, Optical Resolution of Racemic Mixtures of Amino Acids through Nanofiltration Membrane Process, Separation Science and Technology, 49 (2014) 2630-2641.

[49] D.L. Oatley, L. Llenas, R. Pérez, P.M. Williams, X. Martínez-Lladó, M. Rovira, Review of the dielectric properties of nanofiltration membranes and verification of the single oriented layer approximation, Advances in Colloid and Interface Science, 173 (2012) 1-11.

[50] A. Al-Amoudi, P. Williams, S. Mandale, R.W. Lovitt, Cleaning results of new and fouled nanofiltration membrane characterized by zeta potential and permeability, Separation and Purification Technology, 54 (2007) 234-240. 


\subsection{Supplementary Material}

The following are the supplementary data provided for this work.
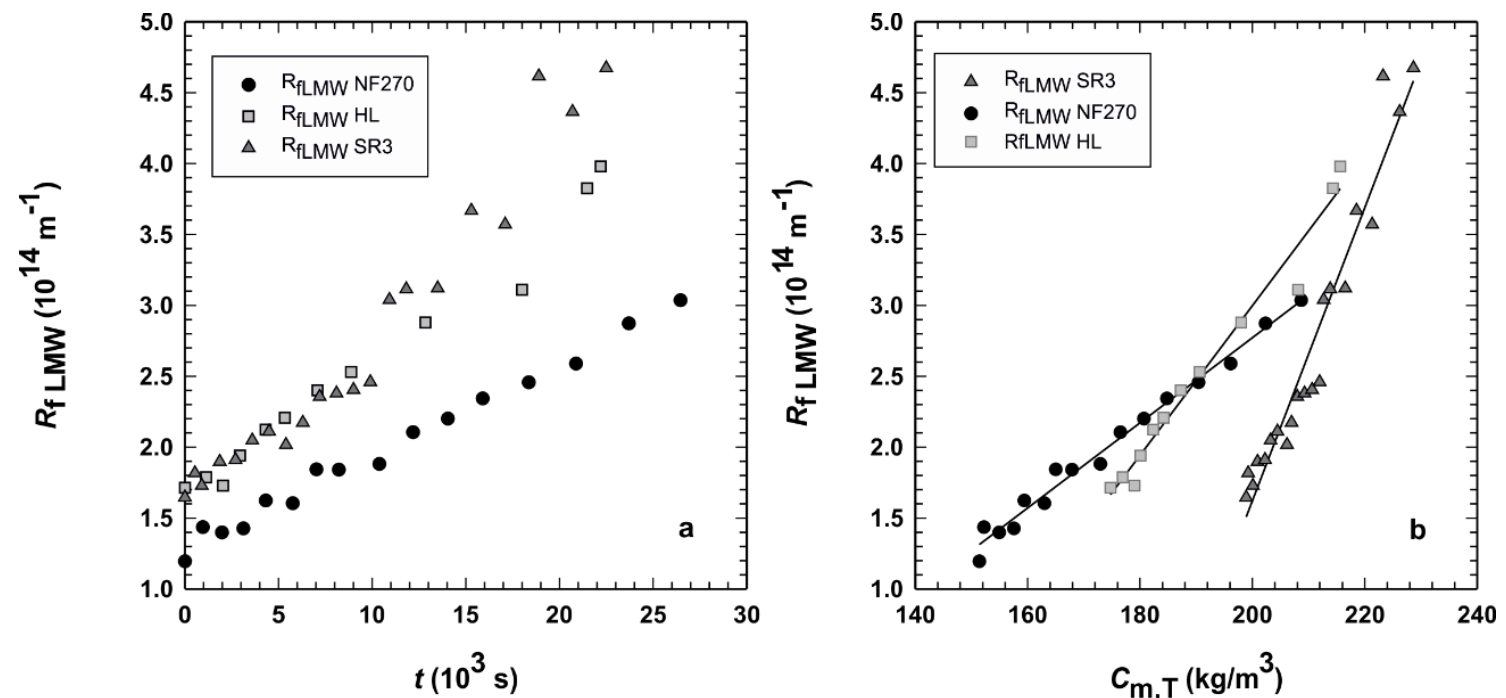

Figure S4.1 Evolution of $R_{f(L M W)}$ for the synthetic solution for the three membranes: (a) as a function of filtration time, (b) as a function of total sugar concentration in the membrane surface $C_{\mathrm{m}, \mathrm{T}}$. 
SECTION III. SCALE-UP A OF NANOFILTRATION PROCESS FOR SUGAR REDUCTION OF GRAPE MUST. ELABORATION OF LOW ALCOHOL CONTENT WINES 



\section{Chapter 5}

\section{Comparative Study of Red Grape Must Nanofiltration: Laboratory and Pilot Plant Scales}

Camila M. Salgado ${ }^{1}$, Laura Palacio ${ }^{1}$, Pedro Prádanos ${ }^{1}$, Antonio Hernández ${ }^{1}$, Carlos González- Huerta², Silvia Pérez-Magariño².

\footnotetext{
${ }^{1}$ Grupo de superficies y Materiales porosos (SMAP, UA-UVA-CSIC), Dpto. de Física Aplicada, Facultad de Ciencias, Universidad de Valladolid, 47011 Valladolid, Spain. ${ }^{2}$ Instituto Tecnológico Agrario de Castilla y León, Ctra. Burgos Km 119. Finca Zamadueñas. 47071 Valladolid. Spain.
}

This chapter has been published in:

Food and Bioproducts Processing 94 (2015) 610-620

DOI: http://dx.doi.org/10.1016/j.fbp.2014.08.007 



\section{Chapter 5. Comparative Study of Red Grape Must Nanofiltration: Laboratory and Pilot Plant Scales}

\section{Abstract}

A consequence of global warming is the early ripening of grapes which promotes, among others, a higher fermentable sugar (glucose and fructose) content. This leads to wines with an alcoholic degree higher than desired.

In this work, the main differences between red grape must nanofiltration at laboratory and pilot plant scale were studied in order to perform the scale-up of a nanofiltration process to reduce the sugar content. For this, previous results of the nanofiltration of commercial red must using the SR3 membrane in a flat sheet crossflow module were compared with those obtained for the filtration of natural red must using the same membrane in a spiral wound module at two different applied pressures.

The aim of this publication is to analyze the main differences between red grape must nanofiltration at laboratory and at pilot plant scale.

Results showed that the flow destabilization and eddy promotion caused by spacers in the spiral wound module mitigate the rate at which the cake thickens and compacts on the membrane surface. This causes a less sharp flux decrease, less variable sugars rejection and osmotic pressure difference. Moreover, higher applied pressure promotes a higher membrane fouling and osmotic pressure that worsen the flux decay.

Keywords:

Red grape must, Nanofiltration, Scale-up, Spiral wound module, sugar content reduction 


\subsection{Introduction}

Membrane processes are now widely considered as economical alternatives to conventional separation processes. Reverse osmosis (RO), nanofiltration (NF), ultrafiltration (UF) and microfiltration (MF) have become standard unit operations [1].

Membranes can be presented in several configurations such as: spiral wound, hollow fibers, tubular and plate-and-frame modules. Amongst these, the hollow fiber and the spiral wound modules are the most commonly used, due to their high membrane area to volume ratio. Moreover, spiral wound modules are often preferred in industry because they offer a good balance between ease of operation, fouling control, permeation rate and packing density [1, 2].

Some membrane processes have been used in winemaking for a long time. For example: cross-flow MF and UF to clarify white grape must [3], sugar concentration using NF [4] and RO [5] in musts. Reverse osmosis is also used to reduce alcohol in wines, unfortunately, $\mathrm{RO}$ membranes are permeable to both alcohol and water, and after the filtration it is necessary to add water to the dealcoholized wine which creates legal problems in some countries where the addition of water is forbidden by law [6].

Furthermore, more recent research and development activities have focused on the application of membrane technologies for sugar control in grape musts in order to reduce the alcohol content of the resulting wines [6-8]. As a consequence of global warming, an early ripening of grapes has been detected in some regions that causes higher fermentable sugar (glucose and fructose) content, lower acidities and some modifications of the varietal aroma compounds. Fermentation of this must leads to alcoholic degrees higher than desired [9], as they may be too burning in the mouth and mask the fruity aromas and taste of wine. Premature grape harvest and winemaking should affect the final wine quality, leading to more acid and less colored wines, because the phenolic maturity would not be fully achieved [8]. Therefore, in order to produce a full flavored wine, the harvest should be carried out in the optimum ripeness of the fruits and then innovative techniques to control sugars in musts should be applied to keep the alcohol degree of the resulting wines within the desired range. Moreover moderated alcohol contents are becoming a trend in the consumers demand.

If the molecular weight of sugars in must is taken into account, nanofiltration seems to be the most appropriate technique to control the concentration of glucose and fructose [7]. In their work, Garcia-Martin et al. studied the sugar reduction of fermentable sugars in musts such as glucose and fructose by a 2 stage nanofiltration process to obtain wines with a slight alcohol reduction [6, 8]. Their results showed that the mixture of the final permeate with the retentate or with untreated must in adequate 
proportions reduced the alcohol content of the resulting wines by $2^{\circ}$. However, a slight loss of color and aroma intensity and a slender unbalancing of some important substances (i.e. potassium, malic and tartaric acid) were detected. Moreover, these experiments of must nanofiltration, showed that there are some problems specially related with the permeate flux decline.

In our previous work [10], a method was proposed to study the influence of the different compounds present in red grape must on flux decline. Results showed that high molecular weight compounds (namely polyphenols, polysaccharides, proteins, etc) have more influence on the permeate flux decay since they are mainly responsible for the fouling phenomenon (cake filtration mechanism). While low molecular weight compounds (mainly glucose and fructose), contribute to the flux decay mostly through an increase of the osmotic pressure during the process. Aiming to select the most appropriate NF membrane for sugar control in grape must, further research was performed applying the same methodology mentioned in previous works [10]. In this work [11], the performance for must nanofiltration of 3 flat sheet NF membranes was compared: the NF270 (Dow Filmtec), HL (GE) and SR3 (Koch Membrane System). The results obtained showed that the $\mathrm{HL}$ and SR3 membranes were appropriate to reduce the content of sugar of red must. Specifically, the SR3 membrane showed the best passage of sugar and less fouling. Once the membrane is selected at a laboratory scale it is reasonable to analyze its performance at a higher scale using a spiral wound module.

The major components of a spiral wound module are the membrane, the feed and permeate channels, spacers in the feed and permeate channels, the permeate tube and the membrane housing $[1,12]$. The feed flow spacers, which usually consist in non-woven nearly cylindrical filaments, serve to separate adjacent leaves of the membrane and to create flow passages, but also to promote flow unsteadiness and therefore, to enhance mass transport. In this way, the undesirable fouling, concentration polarization and osmotic pressure on the membrane surface are mitigated [13]. The trade-off for a higher mass transfer rate is an increased pressure loss along the feed channel [1].

The geometry of a spiral wound module is described by the number of leaves, $N_{L}$, the leaf length, $L$, and leaf width, $W$, of each membrane leaf, the feed channel height, $H$, and permeate channel height, $H_{P}$. The channels heights are defined by the feed and permeate spacer heights. The spacers themselves are characterized by the mesh size, $I_{m}$ (distance between filaments); filament thickness, $d(d=H / 2)$; the ratio of them $\left(I_{m} / d\right)$; orientation of the filaments, $\beta$; angle of the feed flow, $\theta$; hydraulic diameter, $d_{h}$, and voidage, $\varepsilon$, the volume of the voids divided by the overall volume $[1,14]$. Figure 
5.1 provides the top view of a spacer where the geometric characteristics can be appreciated.

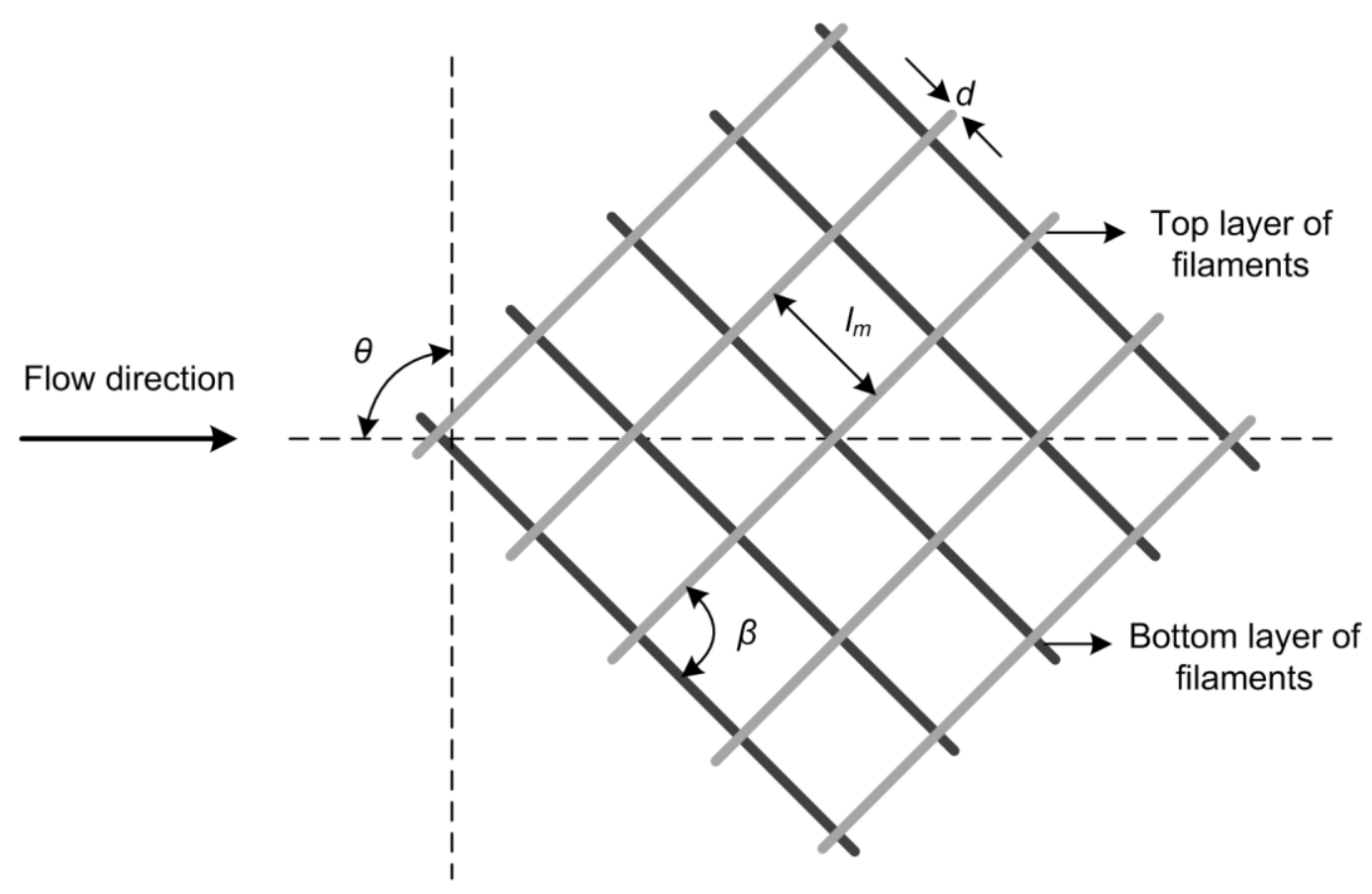

Figure 5.1 Geometric characteristics of a spacer; top view.

The hydrodynamics in a spiral wound module is critically influenced by the presence of the spacer material. Since the height of the feed channel of the spiral wound module is very small $(0.5-2 \mathrm{~mm})$, the effect of its curvature on the flow can be neglected and hence the flow can be modeled assuming a thin rectangular channel filled with spacers [14]. The presence of spacer materials in the channel reduces the void volume and hydraulic diameter $\left(d_{h}\right)$ while raises the effective velocity $\left(\vartheta_{\text {eff }}\right)$.

Furthermore, due to the small spacer height, the circulating velocity does not exceed $0.4 \mathrm{~m} / \mathrm{s}$ and the pressure drop, recommended by manufacturers, should be between 0.4-0.7 bar. Therefore, the Reynolds number, defined on the basis of the average velocity and the spacer filament diameter, is less than 200 [13].

Due to the low feed flow rates, the role of feed spacers in mass transfer enhancement is of utmost importance [2].Several experimental works in planechannels containing different periodic arrays of small-diameter cylinders (mimicking spacers) showed that the presence of them caused a flow destabilization [15-17]. In fact, it has been concluded [16] that this cylinders act as eddy promoters and their presence leads to the destabilization of the flow by essentially the same mechanism as in rectangular channels but at much lower Reynolds numbers (on the order of hundreds rather than thousands). In more recent studies, [13] the flow inside 
rectangular channels with non-woven diamond-shaped spacers were studied using direct numerical simulation. The results revealed that, for the range of geometrical parameters examined, the transition Reynolds number occurs at relatively low values: $\mathrm{Re}=35-45$.

According to other studies [14], spacer-filled channels exhibit significantly higher mass transfer rates compared to empty channels over the same range of Reynolds numbers. Further research on the influence of the geometry of the spacers on the Sherwood number [18] using numerical simulations and experimental data were performed developping dimensionless correlations for mass transfer coefficients of the usual form, $S h=a \cdot \operatorname{Re}^{m} \cdot S c^{n}$ for spacer each geometry.

As mentioned, previous studies at laboratory scale have been performed for the application of nanofiltration in order to control the sugar content of red grape must to produce low alcohol wine $[10,11]$. In the present work the scale-up of the selected nanofiltration process is performed as a continuation of the mentioned studies.

The aim of the present publication is to analyze the main differences between red grape must nanofiltration at laboratory and at pilot plant scale using the same membrane. Specifically the fouling mechanisms, sugars rejection and osmotic pressure are compared. The analysis of these processes can be considered as the first stage of the optimization of the procedure for sugar reduction of must at a higher scale.

For this purpose, the previous results obtained for the nanofiltration of commercial red must using the SR3 membrane in a flat sheet crossflow module [11] are compared with those obtained for the filtration of natural red must using the same membrane in a spiral wound module.

Moreover, because in our previous studies $[10,11]$ the increase of the osmotic pressure was considered to be a limiting factor of the permeate flux, the study of the increase of the applied transmembrane pressure is relevant. Therefore the effect of the variation of the applied pressure in the performance of the spiral wound module will be also analyzed in order to continue with the optimization process.

\subsection{Theory}

\subsubsection{The Spiral Wound Module}

\subsubsection{Flow conditions in a Spiral Wound Module}

As already mentioned, the flow in a spiral wound module can be modeled assuming a thin plane channel filled with spacers, neglecting the effects of the curvature of the module. 
The overall voidage fraction $(\varepsilon)$ can be evaluated by $[14,19]$

$\varepsilon=1-\frac{V_{s p}}{V_{t}}$

where $V_{s p}$ and $V_{t}$ are the volume occupied by the spacer and the total channel volume respectively.

$V_{s p}$ and $V_{t}$ can be calculated by

$V_{s p}=0.5 \cdot \pi \cdot d^{2} \cdot I_{m}$

$V_{t}=I_{m}^{2} \cdot H$

The effective area, $A_{\text {eff }}$, can be calculated from the leaf width $(W)$, height $(H)$ and porosity $(\varepsilon)$ of the spacer as

$$
A_{\text {eff }}=W \cdot H \cdot \varepsilon
$$

Therefore, the effective velocity in a spiral wound element can be calculated according to

$$
\vartheta_{\text {eff }}=\frac{Q}{W \cdot H \cdot \varepsilon}
$$

where $Q$ is the volumetric recirculation flow.

For a spacer- filled flat channel the resulting expression for the hydraulic diameter, $d_{h}$, is [14]

$$
d_{h}=\frac{4 \cdot \varepsilon}{\frac{2}{H}+(1-\varepsilon) \cdot a_{s p}}
$$

The specific surface area of the spacer $\left(a_{s p}\right)$ is defined as the ratio between its surface area and its volume:

$$
a_{s p}=\frac{A_{s p}}{V_{s p}}
$$


and Asp is defined as

$$
A_{s p}=2 \cdot \pi \cdot I_{m} \cdot d
$$

\subsubsection{Mass- transport in spacer-filled channels}

Estimates of the mass transfer coefficient in the presence of different spacers can be obtained [18] by using the appropriate correlation; that, for the spacer used in the present work, states that the Sherwood $(S h)$ number can be written in terms of the Reynolds $(R e)$ and Schmidt $(S c)$ numbers as

$$
S h=0.14 \cdot R e^{0.64} \cdot S c^{0.42}
$$

The Sherwood, Schmidt and Reynolds numbers are defined as

$$
S h=\frac{K_{\mathrm{m}, i} d_{\mathrm{h}}}{D_{i}}, \quad S c=\frac{\eta_{\mathrm{f}}}{\rho_{\mathrm{f}} D_{i}}, \quad \operatorname{Re}=\frac{v \rho_{f} d_{h}}{\eta_{f}}
$$

where, $K_{\mathrm{m}, i}$, and $D_{i}$ are the mass transfer and the diffusion coefficient of the $i$-th component respectively and $\eta_{f}$ and $\rho_{f}$ stand for the viscosity and density of the feed respectively.

Taking into account that the membrane is semipermeable, the value of $K_{m, i}$ calculated using Eqs 9 and 10, that should be valid for an impenetrable wall, needs to be corrected to $K_{m, i}^{s}$ according to [20]:

$$
K_{m, i}^{s}=k_{m, i}\left[\left(\frac{J_{v}}{K_{m, i}}\right)+\left(\frac{J_{v} / K_{m, i}}{\exp \left\{J_{v} / K_{m, i}-1\right\}}\right)\right] \text { for } \quad J_{v} / K_{m, i} \leq 1
$$

\subsubsection{Permeate flux decrease}

When the overall filtration process is taken into account, the flux through the membrane per unit of membrane area can be written in terms of the applied transmembrane pressure, $\Delta p$, the osmotic pressure gradient, $\Delta \pi$, the feed viscosity, $\eta_{\mathrm{f}}$, and the system resistance, $R_{\text {sys }}$ by [21-24] 


$$
J_{v}=\frac{\Delta p-\Delta \pi}{\eta R_{\text {sys }}}
$$

In filtration processes where the concentration of small and medium sized molecules increases, the flux decreases with time (or filtered volume). This decrease has been attributed to three fundamental factors: the increase of both osmotic pressure and viscosity of the solution that passes through the pores of the membrane and the evolution of the total resistance of the membrane system, $\Delta \pi, \eta$, and $R_{\text {sys }}$ respectively [25-27].

The overall system resistance, $R_{\mathrm{sys}}$, is the sum of the membrane resistance, $R_{\mathrm{m}}$, plus a series of terms that depend on the fouling caused by the solute and the membrane itself, $R_{\mathrm{f}}$ :

$$
R_{\mathrm{sys}}=R_{\mathrm{m}}+R_{\mathrm{f}}
$$

Assuming that the osmotic pressure follows the van't Hoff's law, the osmotic pressure difference generated by all components can be calculated as

$$
\Delta \pi=\sum_{i=1}^{N} \Delta \Pi_{i}=\sum_{i=1}^{N} \frac{R T}{M_{i}}\left(C_{\mathrm{m}, i}-C_{\mathrm{p}, i}\right)
$$

here $M_{i}$ is the molar weight, $C_{\mathrm{m}, i}$ the concentration on the membrane surface, $C_{P, i}$ the permeate concentration of the $i$-th component, $\mathrm{R}$ the gas constant, and $T$ the temperature. In order to use $\mathrm{Eq} 15$, it is necessary to calculate the experimentally inaccessible concentration $C_{\mathrm{m}, i}$. One of the methods to do this consists in the use of the Film Theory of concentration polarization.

\subsubsection{Concentration Polarization. Film theory}

This model is based on the use of the mass transfer coefficient, $K_{\mathrm{m}, \text { i, }}$ in order to describe the solute transport in the membrane active layer [27, 28] as

$$
C_{\mathrm{m}, i}=C_{\mathrm{p}, i}+\left(C_{0, i}-C_{\mathrm{p}, i}\right) e^{\left(J_{v} / K_{m, i}\right)}
$$


here, $J_{v}$ is the flux through the membrane defined by Eq 12; $C_{0, i}$ and $K_{m, i}$ are the feed concentration and the mass transfer coefficient of the $i$-th component respectively. The last one can be evaluated by Eqs 9, 10 and 11.

\subsubsection{Fouling mechanism. Cake Filtration}

The additional resistance attributed to fouling, $R_{\mathrm{f}}$, has been related with phenomena such as concentration polarization, gelation, deposition, adsorption of solute molecules inside the pores or pore blocking when the pore size is similar to the molecular dimensions [29-33]. All these processes should influence in a more or less balanced equilibrium. They can be accounted by means of four theoretical kinetic models commonly used for systems showing flux decline [32, 34]: complete blocking, intermediate blocking, standard filtration and cake filtration models.

In several previous experiments using different flat sheet membranes for grape must nanofiltration $[10,11]$, only the very first instants of filtration seemed to be described by an intermediate blocking mechanism.

During, the second and longest step of must nanofiltration, flux decay follows the cake filtration mechanism [10]. According to this model, each particle locates on others already arrived and already blocking some pores and there is no room for a direct obstruction of any membrane area. In this case the fouling kinetic constant is $k_{\mathrm{C}}$ (in $\mathrm{s} / \mathrm{m}^{6}$ ) and can be written as

$$
\frac{t}{V_{\mathrm{P}}}=\frac{k_{\mathrm{c}}}{2} V_{\mathrm{P}}+\frac{1}{J V_{0} \cdot A_{m}}
$$

The kinetic constant $k_{\mathrm{c}}$ is twice the Membrane Fouling Index (MFI) [35] that is defined as the slope of the plot of $t / V_{\mathrm{p}}$ versus $V_{\mathrm{p}}$.

According to several studies [36-39] on fouling of nanofiltration membranes, the cake layer formed on the membrane surface may be compressible and become more compact and dense after a certain period of filtration time or due to an increase of the applied pressure. In fact, another work described that a third mechanism may occur during the flux decline, the so called "cake filtration with compression model" [35].

\subsubsection{Retention model}

The efficiency of a membrane is determined by its true retention, $R$. This coefficient is defined as 
$R_{i}=1-\frac{C_{\mathrm{p}, i}}{C_{\mathrm{m}, i}} \quad(i=1,2 \ldots N)$

for the $\mathrm{i}$-th component present as solute in the feed. $C_{\mathrm{m}, \mathrm{i}}$ is the concentration of the $\mathrm{i}$-th component on the membrane surface (membrane active layer) and $C_{\mathrm{p}, i}$ the permeate concentration of the i-th component.

\subsection{Materials and Methods}

\subsubsection{Membrane and Experimental Set-up}

The experimental set-up used for must filtrations was similar to the one described in a previous work [10] for the laboratory scale experiments using a flat sheet cross flow module. The main difference, with the scheme presented there, is that the present experiments were performed in a pilot plant scale unit with a spiral wound module of nanofiltration. Briefly, it consists in a feed vessel, with a cryogenic unit to assure that the feed's temperature is kept at $16{ }^{\circ} \mathrm{C}$. The feed is extracted from the thermostated reservoir by means of a regulatable piston membrane pump Hydra - Cell G03. Two pressure transducers are placed before and after the spiral wound module to measure the inlet and outlet pressure. In order to adjust manually the pressure inside the module a needle valve is placed at the exit of the unit. Cross flow is adjusted through this valve and the speed control of the pump. The retentate flow rate is measured with a flowmeter ranging from 0 to $10 \mathrm{~L} / \mathrm{min}$. In order to decrease the retentate temperature a heat exchanger was placed before its return to the feed vessel. The permeate flux was monitored using a three-tube flow system with flow capacity from 0 to $10 \mathrm{~L} / \mathrm{min}$.

The membrane used for the nanofiltrations was a KMS SR3 (reference 3839 SR3- NYV), made and commercialized by Koch Membrane Systems. The main characteristics of the membrane and the spiral wound module are shown in Tables 5.1 and 5.2 respectively. The spacer porosity was assumed to be that determined by Vrouwenvelder, et al. [40] in their work using a diamond- shaped spacer with the same height as the SR3 $\left(H=0.787 \cdot 10^{-3} \mathrm{~m}\right)$. 
Table 5.1. Nominal data of the SR3 membrane.

\begin{tabular}{ccccc}
\hline $\begin{array}{c}\text { MWCO } \\
(\mathrm{Da})^{\mathrm{a}}\end{array}$ & $\begin{array}{c}\text { Lactose } \\
\text { Rejection } \\
(\%)^{\mathrm{a}}\end{array}$ & $\begin{array}{c}\mathrm{pH} \\
\text { rang } \\
\text { e }\end{array}$ & $\begin{array}{c}\text { Max. } \\
\text { Pressure } \\
\left(\mathbf{1 0 ^ { 5 }} \mathbf{~ P a}\right)\end{array}$ & $\begin{array}{c}\text { Max. } \\
\text { Temperature } \\
(-\mathrm{C})\end{array}$ \\
\hline 200 & 99.900 & $3-10$ & 41.400 & 50.000 \\
\hline${ }^{2} \%$ Lactose at $1380 \mathrm{kPa}$ & & &
\end{tabular}

Table 5.2. Main characteristics of the SR3 membrane and 3839 SR3-NYV Spiral Wound Module

\begin{tabular}{|c|c|c|c|c|c|}
\hline $\begin{array}{c}\text { Active } \\
\text { membrane } \\
\text { Area } \\
A_{m}\left(\mathrm{~m}^{2}\right)^{\mathrm{a}}\end{array}$ & $\begin{array}{c}\text { Module } \\
\text { Length } \\
L(\mathrm{~m})^{\mathrm{a}}\end{array}$ & $\begin{array}{l}\text { Module } \\
\text { diameter } \\
(\mathrm{m})^{\mathrm{a}}\end{array}$ & $\begin{array}{l}\text { Leaf with } W \\
(\mathrm{~m})^{\mathrm{b}}\end{array}$ & $\begin{array}{c}\text { Feed } \\
\text { spacer } \\
\text { height } \\
H\left(10^{-3} \mathrm{~m}\right)^{a}\end{array}$ & $\begin{array}{c}\text { Feed } \\
\text { spacer } \\
\text { porosity }^{\mathrm{c}} \\
\varepsilon\end{array}$ \\
\hline 7.061 & 0.984 & 0.096 & 3.608 & 0.787 & 0.850 \\
\hline
\end{tabular}

a Provided by the manufacturer

${ }^{\mathrm{b}}$ Own determination

${ }^{c}[40]$

As mentioned, prior to the selection of the SR3 membrane, different nanofiltration membranes in flat sheet configuration were tested using a commercial red must and a synthetic solution containing the main low molecular weight compounds typically found in red must. Results showed that, among the membranes studied, the SR3 presented an appropriate passage of sugars and less fouling [11].

\subsubsection{Must}

Tempranillo red grapes from D.O. Rueda were transported to the experimental winery of the Enological Station of Castilla y Leon (Rueda) in plastic boxes of $15 \mathrm{~kg}$. After the reception, grapes were de-stemmed and crushed and sulfite was added (60 $\mathrm{mg} / \mathrm{L}$ of $\mathrm{SO}_{2}$ ). The must was obtained by drawing off, without press. Pectinolytic enzymes (10mg/L of Novoclear Speed, Lamothe Abiet, France) were added to enhance first clarification. After that, must was filtered through $0.8 \mu \mathrm{m}$ cellulose plate filters in order to prevent sudden membrane fouling and to make nanofiltration easier. In this way natural must clarity is similar to that of the commercial must used in the previous experiments with the flat sheet cross flow module.

The main oenological parameters of the red must before the filtration process are shown in Table 5.3. 
Table 5.3. Oenological parameters of the natural red musts before and after the nanofiltration process.

\begin{tabular}{|c|c|c|c|c|c|c|c|c|}
\hline $\begin{array}{l}\text { Red } \\
\text { grape } \\
\text { must }\end{array}$ & $\begin{array}{c}\text { Glucose } \\
(g / L)\end{array}$ & $\begin{array}{l}\text { Fructose } \\
\qquad(g / L)\end{array}$ & $\begin{array}{c}\mathrm{TH}_{2} \\
(\mathrm{~g} / \mathrm{L})\end{array}$ & $\begin{array}{l}\mathrm{MH}_{2} \\
(\mathrm{~g} / \mathrm{L})\end{array}$ & $\begin{array}{c}\mathrm{K} \\
(\mathrm{mg} / \mathrm{L})\end{array}$ & $\mathrm{pH}$ & $\begin{array}{l}\text { Total } \\
\text { acidity } \\
\text { (g/L) }\end{array}$ & $\begin{array}{c}\text { Total } \\
\mathrm{SO}_{2} \\
(\mathrm{~g} / \mathrm{L})\end{array}$ \\
\hline $\begin{array}{c}\text { Original } \\
\text { must }\end{array}$ & 94.49 & 97.51 & 4.82 & 2.64 & 930 & 3.21 & 5.70 & 60 \\
\hline $\begin{array}{l}\text { Permeate } \\
3100 \mathrm{kPa}\end{array}$ & 25.56 & 25.91 & 2.92 & 2.37 & 660 & 3.10 & 4.18 & 21 \\
\hline $\begin{array}{l}\text { Retentate } \\
3100 \mathrm{kPa}\end{array}$ & 134.74 & 139.70 & 4.33 & 2.55 & 1050 & 3.41 & 4.72 & 65 \\
\hline $\begin{array}{l}\text { Permeate } \\
3300 \mathrm{kPa}\end{array}$ & 23.35 & 23.76 & 3.58 & 2.57 & 790 & 3.16 & 5.01 & 24 \\
\hline $\begin{array}{l}\text { Retentate } \\
3300 \mathrm{kPa}\end{array}$ & 130.14 & 134.16 & 4.18 & 2.36 & 900 & 3.28 & 5.27 & 68 \\
\hline
\end{tabular}

\subsubsection{Procedure}

Prior to the initial use of the brand new spiral wound module, a cleaning procedure was performed according to the manufacturer's recommendations in order to remove the preservative solution. Afterwards, to avoid any irreversible change during operation, the membrane was conditioned by pressurization at the highest pressure to be used for a sufficient period of time. In this case, the SR3 was pressurized filtering water at a pressure of $3300 \mathrm{kPa}$ with a recirculation flow of $9 \mathrm{~L} / \mathrm{min}$ during one hour. After this, water permeability was measured. This parameter was determined before and after every filtration and cleaning cycle.

Filtrations were performed in a batch system. The permeate was sent to the thermostated permeate vessel in order to collect it and the retentate was recirculated to the thermostated feed vessel.

In order to analyze the influence of the applied transmembrane pressure two filtrations were performed the first at $3100 \mathrm{kPa}$ and the second one at $3300 \mathrm{kPa}$. These two single and close values do not constitute a study of filtration versus pressure but rather have been chosen to show how increasing pressure without providing extra cake disruption media would have detrimental side effects: increasing fouling, worsening flux decay, and increasing osmotic pressure as will be shown below. The rest of the operating conditions for both filtrations were: a feed temperature of $16{ }^{\circ} \mathrm{C}$ and a recirculation flow of $9 \mathrm{~L} / \mathrm{min}$, which according to Eq 5 and the spacers dimensions (Table 5.2) corresponds to an effective velocity of $6.27 \cdot 10^{-2} \mathrm{~m} / \mathrm{s}$. Between filtrations, 
only one cleaning step was performed, which consisted in a flush cycle with soft water at a recirculation flow of $9 \mathrm{~L} / \mathrm{min}$ and low pressure using a minimum of three times the system hold-up volume and sending retentate and permeate to the drain.

The permeate flux was determined by measuring the flow, firstly every 15 minutes and then, when the permeate flux became less variable, every 45 minutes. Simultaneously, samples of permeate and retentate were taken in order to determine their content of glucose and fructose by liquid chromatography (HPLC).

The volumes filtered where of the order of $35 \mathrm{~L}$ of natural red must. Filtrations were performed until the flux decreased to a more or less constant value during a reasonable period of time.

Results of both filtrations were compared with those obtained previously using the same membrane in a flat sheet cross flow module [11].

\subsubsection{Analytical methods}

Musts were analyzed before and after filtrations according to the methods summarized in Table 5.4. With the exception of sugars, malic and tartaric acid, the oenological parameters analyzed were determined according to the Organisation Internationale de la Vigne et du Vin (OIV) methods [41].

Table 5.4. Summary of the methods used for the determination of some oenological parameters of musts.

\begin{tabular}{cc}
\hline Parameter & Method \\
\hline Glucose and Fructose & HPLC \\
\hline Tartaric and Malic Acid & HPLC \\
\hline $\mathrm{pH}$ & $\mathrm{pH}$ - meter \\
\hline Total acidity & Acid- base titration \\
\hline Total $\mathrm{SO}_{2}$ & lodometry \\
\hline Potassium & Atomic absorption spectroscopy \\
\hline
\end{tabular}

According also with the recommendations of OIV [41], potassium was measured by atomic absorption spectrophotometry using an atomic absorption spectrophotometer from Corning, model FP 410, equipped with an air-acetylene burner.

The chromatographic system used consisted in; an HPLC apparatus, with a Refractive Index detector, Waters 2414; an isocratic pump Waters 1515; the Waters 1707 Autosampler; a thermostated column compartment and a control unit 
commanded by the Breeze 2 software. In order to improve the resolution and precision, the samples were diluted 1:10 (V/V) with deionized water and then $20 \mu \mathrm{L}$ of each were injected in the HPLC system. A Supelco Supelcogel Pb column, and guard column, were used for the sugars (glucose and fructose) separation and a Shodex DE-413 column, and guard column, for malic and tartaric acids detection.

\subsection{Results and Discussion}

\subsubsection{Permeate flux evolution}

As mentioned, water permeability $\left(L_{p}\right)$ was determined before and after the filtrations and cleaning procedure. This parameter was calculated as the slope of the plot of $J_{v}$ versus $\Delta p$ by measuring the permeability of the membrane to Milli-Q water at different transmembrane pressures and at $20 \stackrel{\circ}{\circ}$. The initial and final membrane resistances, $R_{m}$, were calculated from $L_{p}$ data according to Eqs. 12 and 13 when $R_{f}=0$ and $\Delta \Pi=0$. Results are presented in Table 5.5. It is shown that after the first red must filtration and rinsing, the water permeability was reduced since the recovery was only $58.3 \%$ from the original value. After the cleaning procedure, there is a slight permeability recovery without reaching its original value $(66 \%$ of the permeability of the brand new membrane). This permanent loss of permeability is attributed to the inevitable and irreversible fouling of the membrane system due to the adsorption of substances on the membrane surface or inside the pores.

Table 5.5 Hydraulic permeability and membrane resistance, both initially and after filtration and cleaning procedure

\begin{tabular}{ccc}
\hline Process & $\begin{array}{c}\text { Water Permeability } \\
\boldsymbol{L}_{\boldsymbol{p}}\left(\mathbf{1 0 ^ { - 1 1 }} \mathbf{m} / \mathbf{P a} \cdot \mathbf{s}\right)\end{array}$ & $\begin{array}{c}\text { Membrane Resistance } \\
\boldsymbol{R}_{\boldsymbol{m}}\left(\mathbf{1 0}^{\mathbf{1 3}} \mathbf{m}^{-\mathbf{1}}\right)\end{array}$ \\
\hline Before filtration & 1.35 & 7.37 \\
\hline $\begin{array}{c}\text { After red must rinse } \\
\text { (soft water flush cycle) }\end{array}$ & 0.79 & 12.65 \\
\hline $\begin{array}{c}\text { After manufacturers } \\
\text { cleaning procedure }\end{array}$ & 0.89 & 11.16 \\
\hline
\end{tabular}

The evolution of permeate flux with natural red must as a function of time at both transmembrane pressures is presented in Figure 5.2a. As also observed in previous studies with a SR3 flat sheet module [11], both filtrations throughout the spiral wound module follow a typical flux decline kinetic: at the beginning there is a 
remarkable decrease of flow followed by a less-sharp progressive decay which can be assumed to tend to zero. As expected, higher initial fluxes were measured at the beginning of the filtration at $3300 \mathrm{kPa}$. But this process presented a faster flux decrease and reached lower values than the one at $3100 \mathrm{kPa}$. This difference can be attributed to the fact that a higher driving force (transmembrane pressure) accelerates the cake formation on the membrane surface and promotes a higher compaction of it. This issue will be discussed in more detail in section 5.4.4. Besides, it has to be taken into account that the first filtration was performed with the brand new membrane, which, as already mentioned, presented less initial fouling. Figure $5.2 \mathrm{~b}$ shows the comparison of the normalized flux decay using the spiral wound module and the flat sheet membrane module. Even though the later was performed at a higher tangential velocity $(2.78 \mathrm{~m} / \mathrm{s})$ [11], it is clear that the flat sheet cross flow module reached lower permeate fluxes in a shorter period of time. This issue can be attributed to a faster cake formation and compaction not only due to the higher applied pressure (3500 kPa) but to the absence of spacers that, as already mentioned, mitigate fouling mechanisms.
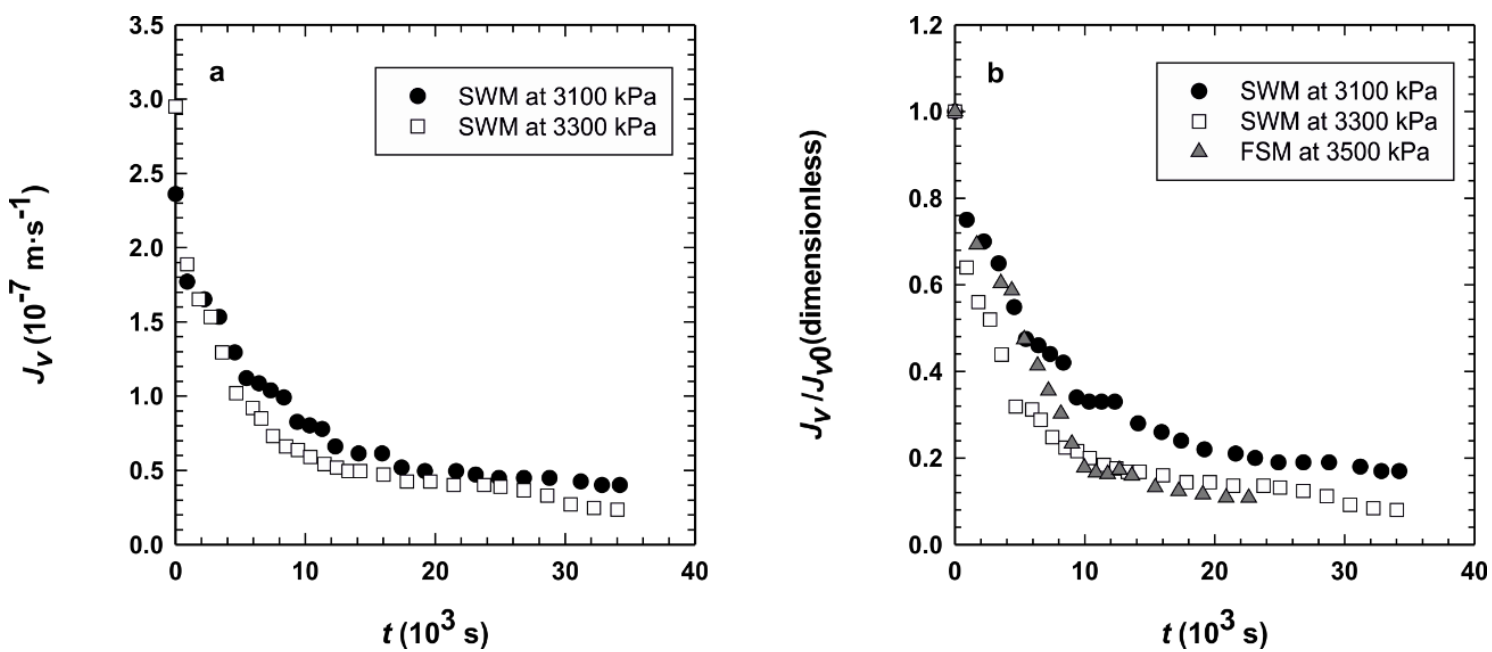

Figure 5.2 Permeate flux time evolution of red must: a) for the spiral wound module (SWM) at $3100 \mathrm{kPa}$ and at $3300 \mathrm{kPa}$; b) normalized for the SWM at $3100 \mathrm{kPa}$ and at $3300 \mathrm{kPa}$ and for the flat sheet module (FSM) at $3500 \mathrm{kPa}$ as a comparison.

\subsubsection{Efficiency of the spiral wound module}

\subsubsection{Analysis of the filtrated musts}

Recalling that the aim of the present study is the analysis of the performance of the SR3 spiral wound module for sugar control in grape must, it is essential to analyze the main characteristics of the obtained musts. Therefore, the concentrations of the resultant permeate and retentate were analyzed. Results presented in Table 5.3 clearly show a high reduction of total sugar content of permeates (about $73 \%$ ) and an increase 
in retentates. These variations are not so significant for the rest of compounds. Furthermore, if the purpose of filtration is to reduce the alcohol content of the final wine, the permeate has to be mixed with untreated must or with the retentate in adequate proportions before its fermentation. In this way, the reconstructed must will be chemically very similar to the original one but with a lower sugar content and the variation of the other compounds will be insignificant.

\subsubsection{Sugars rejection}

Sugar concentration measurements for the permeate and retentate allow the determination of the membrane efficiency by calculating the time evolution of the true retention of each sugar, $R_{i}$. True retentions of glucose and fructose have been evaluated according to $\mathrm{Eq} 18$ and using the equations of mass transport and Film Theory (Eqs 9 to 11 and 15 respectively). For the density, $\rho_{\mathrm{f}}$, of red must a correlation between density and its sugar content (${ }^{\circ}$ Brix) was taken from the literature [42]. In the case of red must, the viscosity, $\eta_{f}$, values used were obtained by a correlation versus concentration ( ${ }^{\circ}$ Brix) [43].

The corresponding results are shown in Figure 5.3a. It can be noted that there is an almost linear slight decrease of retention of both, glucose and fructose. This true retention time evolution differs from the results obtained in previous experiments using the flat sheet module procedure, where a progressive increase of this parameter was observed [11]. A comparison of the rejection of sugars for both the modules is depicted in Figure 5.3b, note that the permeate volume is normalized by the feed volume, $V_{0}$, of each filtration. Although it was expected that both systems presented similar initial rejections, it can be appreciated that the flat sheet module system has lower initial retentions ( 0.181 for glucose and 0.185 for fructose) which increase progressively exceeding the values observed at the beginning of the filtration using the spiral wound module system.

Apparently, the spiral wound module retention is stabilized faster due to an almost instantaneous initial fouling mechanism. Moreover, during the study of the individual effects of low and high molecular weight compounds on the nanofiltration of grape must using a flat sheet membrane, the significant increase of the retention of sugars was also observed in the presence of high molecular weight compounds. This feature was mainly attributed to the formation of the cake layer on the membrane surface that acts as a pseudo-membrane which lowers even more the passage of sugars through the membrane by changing both: permeability and selectivity of the overall membrane [10]. Taking into account that the effective velocity in the spiral wound module was much lower than in the flat sheet module $\left(6.27 \cdot 10^{-2} \mathrm{~ms}^{-1}\right.$ and 2.78 
$\mathrm{ms}^{-1}$ respectively), it is possible that the formation of this pseudo-membrane occurs almost instantly due to the lower shear stress that enables a faster deposition of foulants on the membrane surface. Furthermore, in the flat sheet module the progressive increase of $R_{i}$ would be caused by the thickening of the cake layer on the membrane surface which could not be avoided by the higher shear stress. This corroborates that the presence of feed spacers in the spiral wound module creates local flow structures that periodically disrupt the concentration boundary layers avoiding the thickening of the pseudo - membrane, that is an increase in $R_{i}$. Therefore, the slight decrease of the spiral wound module retention could be explained by the increase of sugars concentration on the retentate side that finally crosses the membrane.
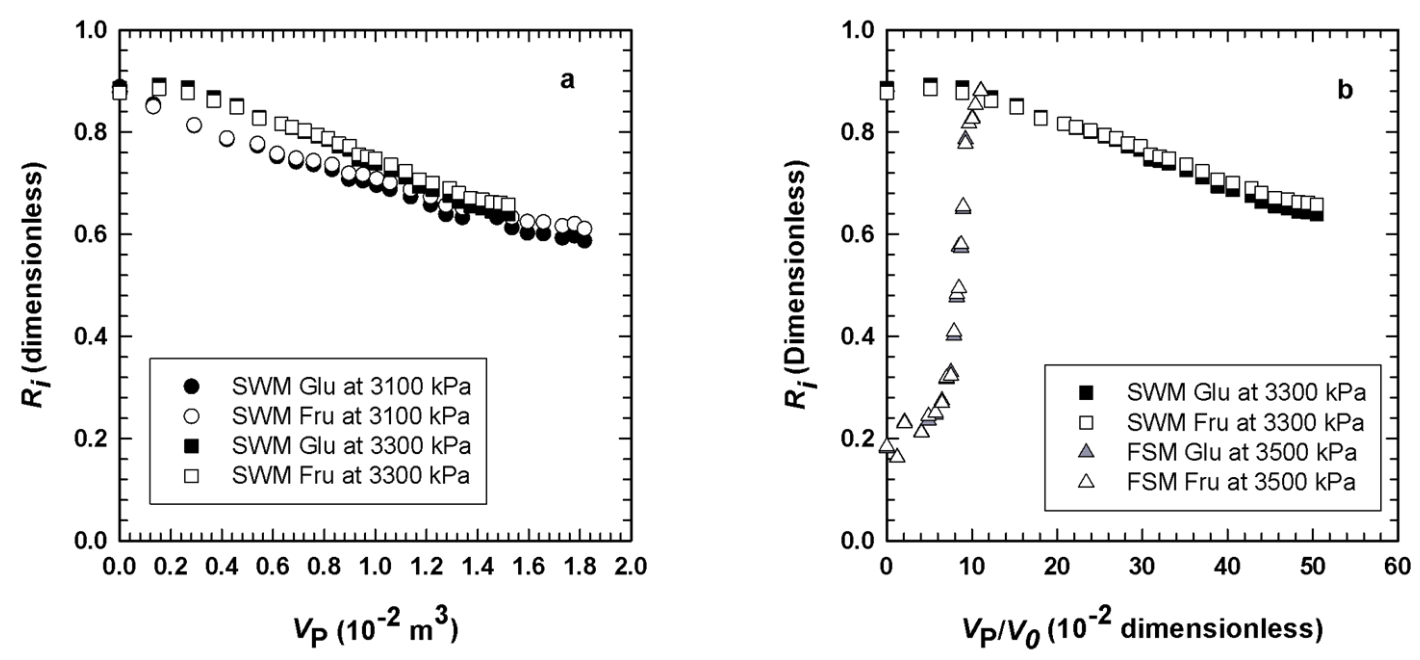

Figure 5.3 True glucose (Glu) and fructose (Fru) retentions: a) as a function of permeate volume $\left(V_{P}\right)$ for the spiral wound module $(S W M)$ at $3100 \mathrm{kPa}$ and at $\left.3300 \mathrm{kPa} ; \mathrm{b}\right)$ as a function of the normalized volume for the SWM at $3300 \mathrm{kPa}$ and for the flat sheet module (FSM) at 3500 $\mathrm{kPa}$ as a comparison.

All in all, the less variable rejection observed using the spiral wound module is more appropriate for the aim of this study (sugar reduction of red must) because it leads to a low sugar content of the permeate from the beginning of the filtration. Furthermore, $J_{V}$ is higher and therefore more $V_{P}$ with the appropriate sugars concentration is collected.

\subsubsection{Resistance to the permeate flux}

The resistance to permeate flux due to fouling, $R_{f}$, was determined according to Eqs. 12 and 13 , assuming that $R_{m}$ increases linearly with time [10]. Figure 5.4 shows 
the results obtained as a function of the filtration time. Here, it can be noticed that there is a slight difference between both the applied pressures. During the filtration at 3100 $\mathrm{kPa}, R_{f}$ increases progressively until reaching a maximum, beyond which there is a slight decrease and possible stabilization. A similar evolution of $R_{f}$ was observed during the filtration using the SR3 flat sheet module [11]. At $3300 \mathrm{kPa}$, this parameter grows continuously reaching higher values and no decay is observed. As reported in previous studies [10,44], a reduction in the resistance due to the cake formation can be caused by an increase of the osmotic pressure. For this purpose it has to be considered that the overall pressure drop (applied transmembrane pressure $\Delta p$ ) at any time is the sum of pressure drops through the membrane, $\Delta p_{m}$, and cake, $\Delta p_{c}$, plus the osmotic pressure, $\Delta \pi$. Besides when the cake has an appreciable thickness, $\Delta p_{m}$ is small in comparison with $\Delta p_{c}$. So, a reduction in the effective pressure across the total membrane system could be due to a reduction of the cake pressure drop, $\Delta p_{c}$ (and so in $R_{f}$ ) that may occur due to an increase in osmotic pressure.

Therefore, it was logic to expect a decrease in resistance for lower transmembrane pressures. Moreover, a higher applied pressure may cause the formation of a more compact cake layer on the membrane surface contributing also to higher values of $R_{f}$.

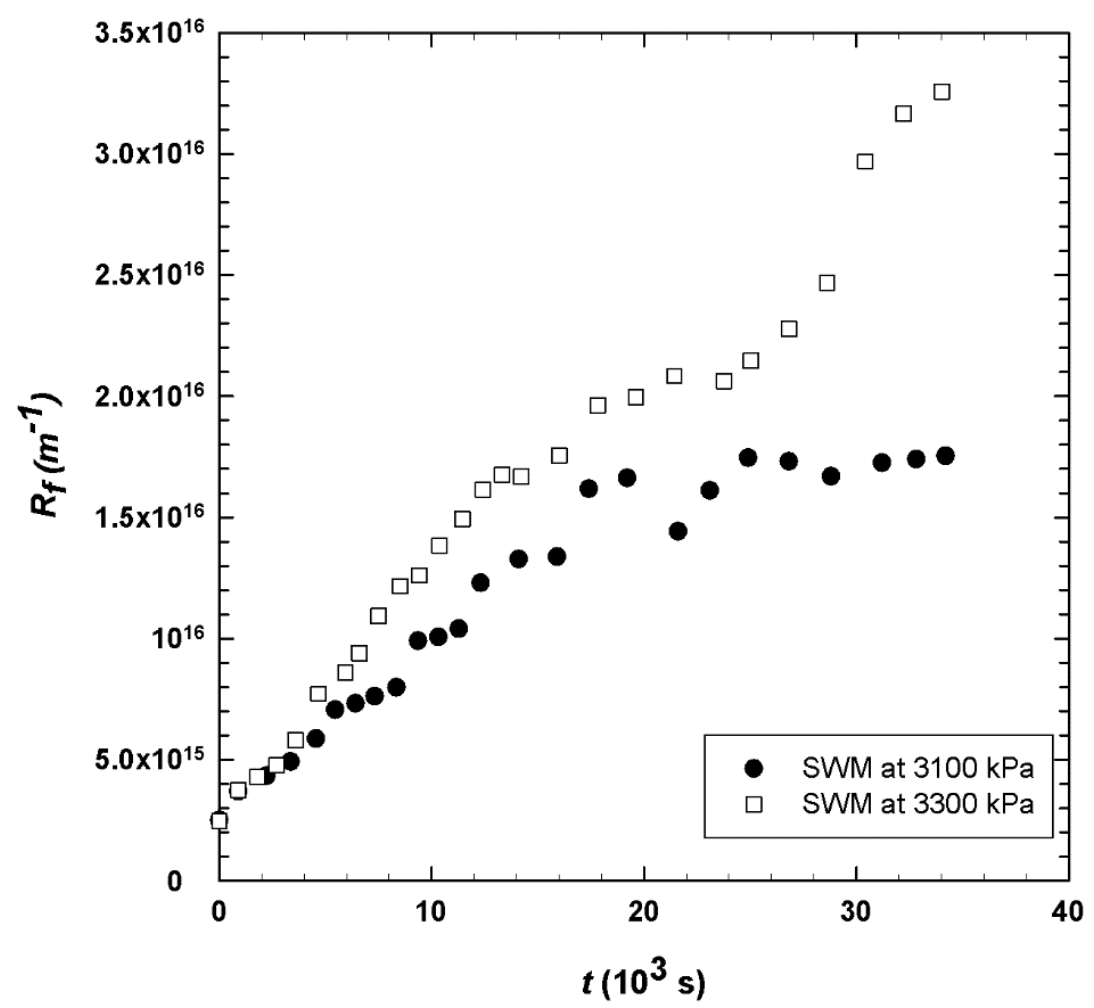

Figure 5.4. Time evolution of the resistance to the permeate flux due to fouling $\left(R_{f}\right)$ for the spiral wound module (SWM) at $3100 \mathrm{kPa}$ and at $3300 \mathrm{kPa}$. 
In order to analyze the influence of the osmotic pressure, the values calculated according to Eq 14 were plotted as a function of the total sugars content of the retentante $\left(C_{R T}\right)$ in Figure 5.5. In this case, no significant osmotic pressure variation can be appreciated. On the contrary, in studies using flat sheet modules, it was observed that this parameter increased remarkably during filtration [10,11] reaching higher values than in the spiral wound module. The values obtained for the SR3 flat sheet module are presented in Figure 5.5 for the sake of comparison. This shows that, as mentioned in 5.4.2.2, spacers increase shear rates, and mass transfer. Therefore, phenomena such as fouling, concentration polarization and osmotic pressure on the membrane surface are mitigated in the long term, and so the thickening of the cake layer is limited. This promotes more stable sugar retention and osmotic pressure difference. By contrast, in the flat sheet membrane filtration, the absence of local flow structures causes the progressive thickening of the cake layer, and consequently less constant osmotic pressure and sugar rejection.

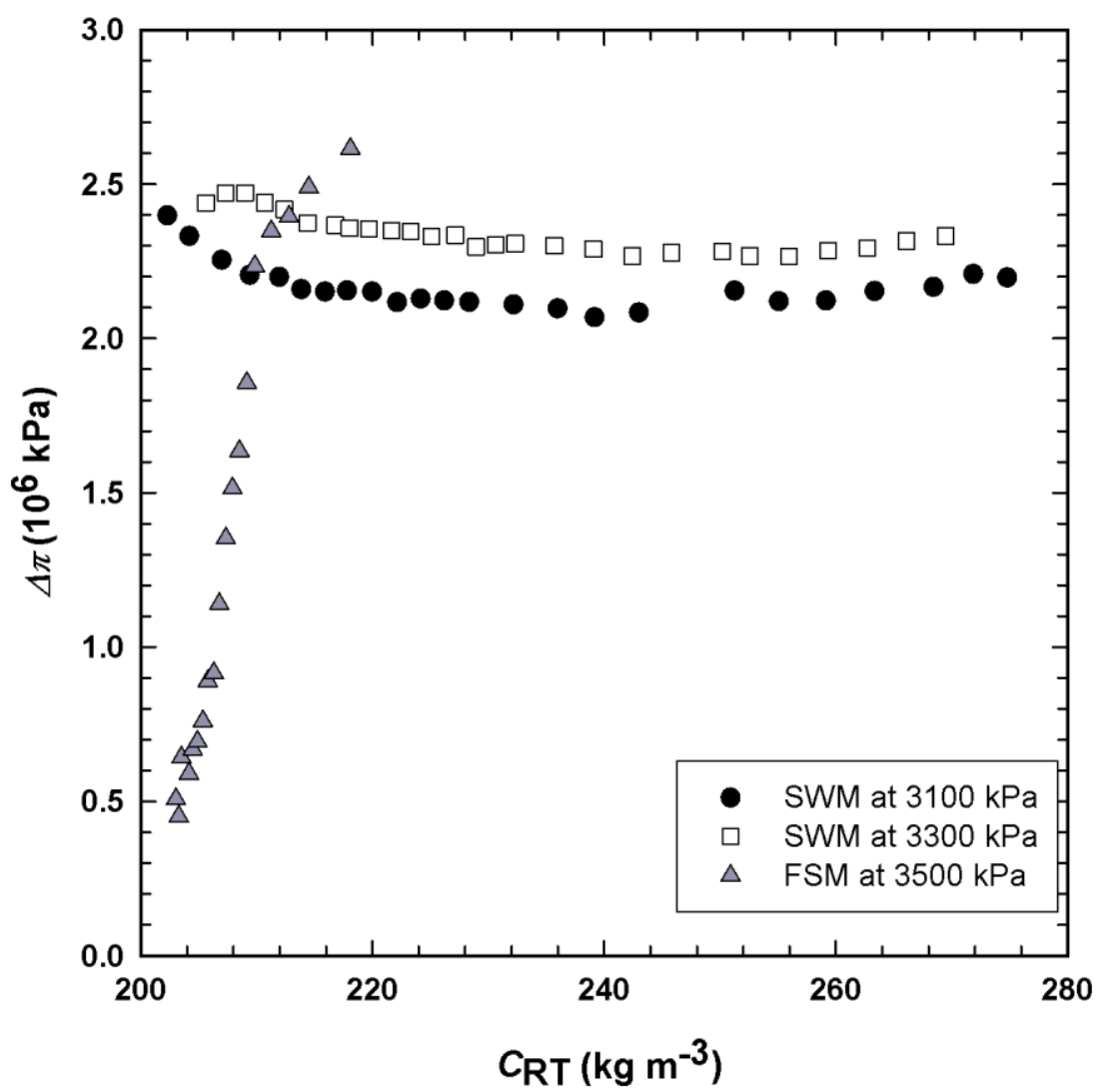

Figure 5.5 Osmotic pressure difference as a function of the total sugars content of the retentante $\left(C_{R T}\right)$ for the spiral wound module $(S W M)$ at $3100 \mathrm{kPa}$ and at $3300 \mathrm{kPa}$ and for the flat sheet module (FSM). 


\subsubsection{Fouling mechanism}

A description of the flux decline presented in Figure 5.2 can be performed in terms of the outlined fouling mechanisms. The fitting of the experimental data to the cake filtration mechanism (Eq 17) is plotted in Figure 5.6. It is observed that for both filtrations the cake filtration model satisfactorily describes the experimental data for almost the entire filtration period and seems to be divided in two regions, the so called: cake formation and cake formation with compaction [35]. Similar results were obtained during the filtration of red must using the flat sheet module [11]. As mentioned elsewhere [10], during the first minutes of must filtration (or the first $1.5 \cdot 10^{-3} \mathrm{~m}^{3}$ of permeated volume) other fouling mechanism as the intermediate blocking could be expected to play a dominant role, but in the present case the process is so fast that any other mechanism rather than cake couldn't be appreciated.

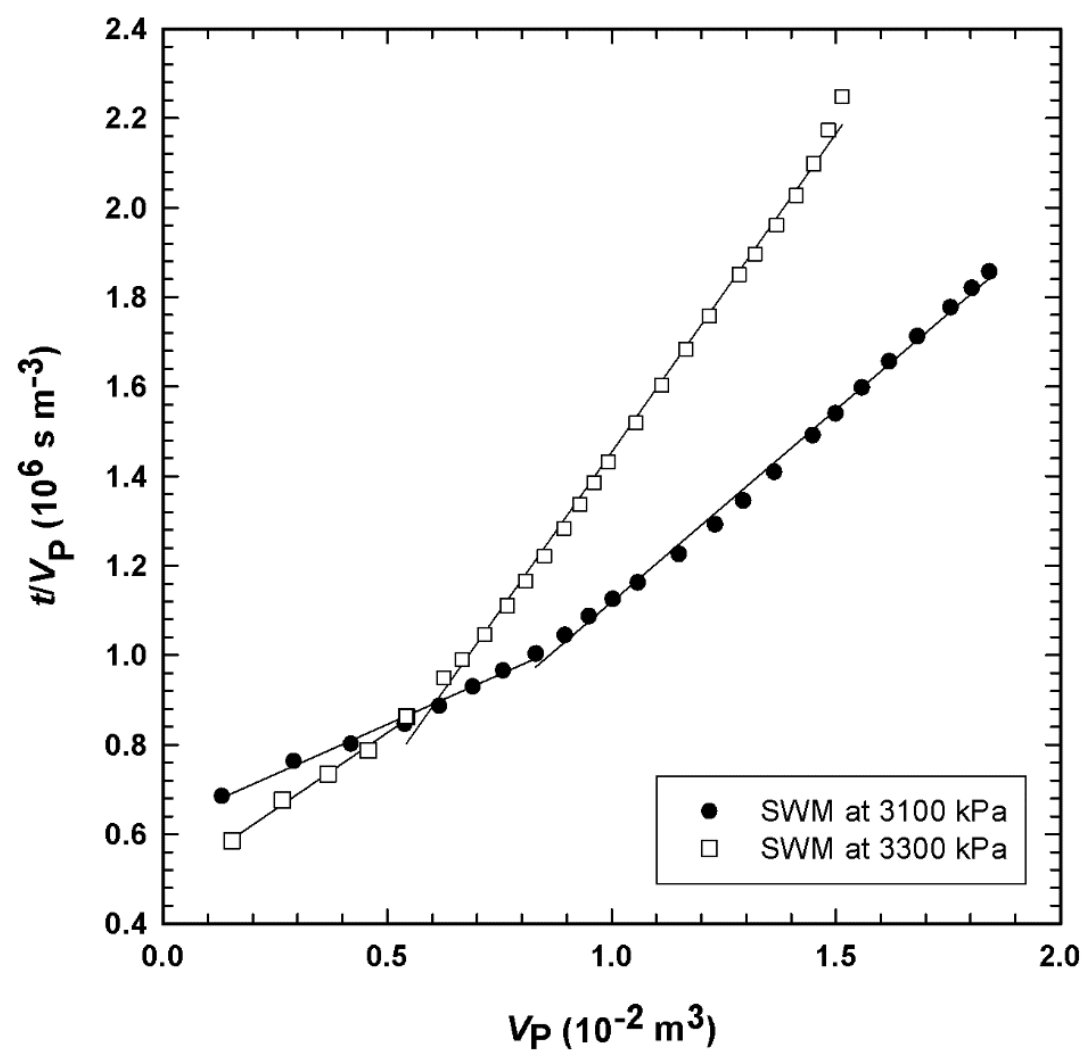

Figure $5.6\left(t / V_{\mathrm{P}}\right)$ vs $V_{\mathrm{P}}$ fitted to the cake filtration model for the spiral wound module (SWM) at $3100 \mathrm{kPa}$ and at $3300 \mathrm{kPa}$. The kinetic constants: $k_{c 1}$ and $k_{c 2}$, for both filtrations, correspond to the slope of the region of cake formation and cake formation with compaction respectively

In order to compare the cake formation kinetic constants $\left(k_{c 1}\right.$ and $\left.k_{c 2}\right)$ of both filtrations along the complete experiments, the slope of each region in the plot $\left(t / V_{\mathrm{P}}\right)$ versus $V_{P}$ (Figure 5.6) was obtained. Results are presented in Table 5.6, where it is 
apparent that the filtration performed at $3300 \mathrm{kPa}$ presented a higher slope that is higher cake formation kinetic constants in both regions $\left(k_{c 1}\right.$ and $\left.k_{c 2}\right)$. This agrees with the flux decline analyzed in section 5.4.1 where even though filtration at $3300 \mathrm{kPa}$ presented a higher initial flux it also reached lower values. Therefore it may be said that the initial flux has a clear effect on the rate of fouling since it affects the rate at which fouling species are brought to the membrane surface. Furthermore, high initial fluxes increase cake compaction and consequently the resistance to the permeate flux $\left(R_{f}\right)$ as mentioned in section 5.4.3. This agrees with the results presented in other studies of the influence of initial flux on membrane fouling [38]. There they concluded that the greater the initial rate, the more severe the fouling of the membrane.

Aiming to analyze the differences of the fouling mechanism between both modules, the results of the cake formation kinetic constants $\left(k_{c 1}\right.$ and $\left.k_{c 2}\right)$ obtained in previous experiments [11] for the flat sheet module are presented in Table 5.6. It is clear that $k_{c 1}$ and $k_{c 2}$ are around 1000 times higher for the flat sheet module. This agrees with the fact that a higher driving force (applied pressure) promotes the rate of fouling and cake compaction. This also corroborates the analysis made in the previous sections 5.4.2.2 and 5.4.3. Even though the formation of the pseudo-membrane is faster in the spiral wound module, the flow destabilization and eddy promotion caused by the spacers mitigates the rate at which the cake thickens on the membrane surface.

Table 5.6 Cake formation kinetic constants of both cake filtration mechanism regions for the spiral wound module and flat sheet module. Values were obtained as the slope of the plot $t / V_{P}$ vs $V_{P}$ for each region in the 3 filtration processes.

\begin{tabular}{cccc}
\hline Module & $\begin{array}{c}\text { Applied pressure } \\
\mathbf{\Delta p}(\mathbf{k P a})\end{array}$ & $\begin{array}{c}\boldsymbol{k}_{\boldsymbol{c 1}} \\
\left(\mathbf{s m}^{-6}\right)\end{array}$ & $\begin{array}{c}\boldsymbol{k}_{c 2} \\
\left(\mathbf{s m}^{-6}\right)\end{array}$ \\
\hline Spiral wound & 3100 & $8.90210^{7}$ & $1.71810^{8}$ \\
\hline Spiral wound & 3300 & $1.37410^{8}$ & $2.84710^{8}$ \\
\hline Flat sheet $^{\mathrm{a}}$ & 3500 & $1.47510^{11}$ & $8.42210^{11}$ \\
\hline${ }^{\mathrm{a}}[11]$ & & &
\end{tabular}

\subsection{Conclusions}

The comparison of the performance of both modules allowed the analysis of the influence of feed spacers on fouling mechanism, time evolution of sugar retention and osmotic pressure during must nanofiltration.

Even though the formation of the pseudo - membrane is faster in the spiral wound module, probably due to a lower tangential velocity, the flow destabilization and 
eddy promotion caused by the spacers mitigates the rate at which the cake thickens and compacts on the membrane surface. The latter causes a less-sharp $J_{v}$ decrease with more appropriate almost constant sugars rejection and small osmotic pressure differences.

Since the latter features were obtained at a lower recirculation flow than with the flat sheet module, it can be concluded that the spiral wound module is more energy efficient too.

The results obtained for the filtrations performed with the spiral wound module show that a higher applied pressure promotes cake formation and compaction and therefore a higher fouling resistance and osmotic pressure that worsen the decrease of $J_{v}$. The optimization of the system wouldn't consist in a simple increase of the applied transmembrane pressure but in promoting higher shear stress (presumably with a higher effective velocity)on the membrane surface combined with higher driving force (applied pressure). Thus, $J_{v}$ would be increased and polarization would be mitigated decreasing also the resistance toward mass transport (i.e. osmotic pressure and fouling).

\subsection{Acknowledgments}

Authors would like to thank the "Ministerio de Ciencia e Innovación (MCINN)" for the financial support of this work within the frame of the "Plan Nacional de I+D+l" through the research projects CTQ2009-07666, CTQ2012-31076 and MAT201020668. We also are grateful to the projects: VA-324A11-2 of the Junta de Castilla y León, and RTA2012-00092-C02 from the INIA of the MICINN. The company Acciona Agua partially founded this research too.

C. Salgado wants to thank the Spanish Ministry of Education for the grant they gave to her within the frame of the "Plan Nacional de Investigación Científica, Desarrollo e Innovación Tecnológica 2008-2011" (FPU grant: AP2010-5769) to complete her PhD. 


\subsection{Nomenclature}

Roman

$A_{\text {eff }}$

Effective area $\left(\mathrm{m}^{2}\right)$

$A_{m}$

Membrane active area $\left(\mathrm{m}^{2}\right)$

$a_{s p}$

Specific surface area of the spacer

$A_{s p}$

Surface area of the spacer $\left(\mathrm{m}^{2}\right)$

$C_{0, i}$

Feed concentration of the $\mathrm{i}$-th component $\left(\mathrm{kg} \mathrm{m}^{-3}\right)$

$C_{m, i}$

Concentration of the $\mathrm{i}$-th component on the membrane active layer $\left(\mathrm{kg} \mathrm{m}^{-3}\right)$

$C_{p, i}$

Permeate concentration of the i-th component $\left(\mathrm{kg} \mathrm{m}^{-3}\right)$

$C_{R T}$

$d$

Total sugar concentration (glucose and fructose) of the retentate $\left(\mathrm{kg} \mathrm{m}^{-3}\right)$

$d_{h}$

Filament thickness $(\mathrm{m})$

$d_{h}$

Hydraulic diameter of the channel $(\mathrm{m})$

$D_{i}$

Diffusion coefficient of the i-th component $\left(\mathrm{m}^{2} \mathrm{~s}^{-1}\right)$

$H \quad$ Feed channel height $(\mathrm{m})$

$J_{v} \quad$ Permeate flux per unit of area through the membrane $\left(\mathrm{m}^{3} \mathrm{~m}^{-2} \mathrm{~s}^{-1}\right)$

$J v_{0} \quad$ Permeate flux per unit of area through the membrane at time $t=0$ $\left(\mathrm{m}^{3} \mathrm{~m}^{-2} \mathrm{~s}^{-1}\right)$

$k \quad$ General kinetic constant for the fouling models $\left(\mathrm{s}^{-1}\right)$

$k_{c} \quad$ Kinetic constant for the cake model $\left(\mathrm{s} \mathrm{m}^{-6}\right)$

$K_{m, i}$

Mass transfer coefficient $\left(\mathrm{m} \mathrm{s}^{-1}\right)$ of the i-th component at impermeable membranes $\left(\mathrm{m} \mathrm{s}^{-1}\right)$

$K_{m, i}^{s} \quad$ Mass transfer coefficient of the i-th component at semipermeable membranes $\left(\mathrm{m} \mathrm{s}^{-1}\right)$

$L \quad$ Leaf length (m)

$I_{m} \quad$ Mesh size $(\mathrm{m})$

$L_{p} \quad$ Water permeability $\left(\mathrm{m} \mathrm{Pa}^{-1} \mathrm{~s}^{-1}\right)$

$M_{i} \quad$ Molar weight of the i-th component $\left(\mathrm{kg} \mathrm{mol}^{-1}\right)$

$n$

Dimensionless exponent which depends of the fouling model

$Q \quad$ Volumetric recirculation flow $\left(\mathrm{m}^{3} \mathrm{~s}^{-1}\right)$

$R$

ideal gas constant $\left(1.987 \cdot 10^{-3} \mathrm{kcal} \mathrm{mol}^{-1} \mathrm{~K}^{-1}\right)$

Re Reynolds number

$R_{f} \quad$ Resistance due to fouling $\left(\mathrm{m}^{-1}\right)$

$R_{i} \quad$ Membranes true retention for the i-th component

$R_{m} \quad$ Membrane resistance $\left(\mathrm{m}^{-1}\right)$

$R_{\text {Sys }} \quad$ System resistance $\left(\mathrm{m}^{-1}\right)$ 


$\begin{array}{ll}\text { Sc } & \text { Schmidt number } \\ S h & \text { Sherwood number } \\ T & \text { Absolute temperature }(\mathrm{K}) \\ V_{0} & \text { Initial volume of grape must }\left(\mathrm{m}^{3}\right) \\ V_{P} & \text { Permeate volume }\left(\mathrm{m}^{3}\right) \\ V_{s p} & \text { Volume occupied by the spacer }\left(\mathrm{m}^{3}\right) \\ V_{t} & \text { Volume of the total (empty) channel }\left(\mathrm{m}^{3}\right) \\ W & \text { Leaf width }(\mathrm{m})\end{array}$

Greek

$\beta$

Angle between crossing filaments

$\Delta \mathrm{p}$

Applied transmembrane pressure $(\mathrm{Pa})$

$\Delta \mathrm{p}_{\mathrm{c}}$

Pressure drop across the cake $(\mathrm{Pa})$

$\Delta \mathrm{p}_{\mathrm{m}}$

Pressure drop across the membrane (Pa)

$\Delta \pi$

Osmotic pressure gradient $(\mathrm{Pa})$

$\varepsilon$

Feed spacer porosity

$\eta \quad$ Viscosity of the solution that passes through the membrane (Pa s)

$\eta_{\mathrm{f}} \quad$ Feed viscosity (Pa s)

$\eta_{\mathrm{p}} \quad$ Viscosity inside the membrane pore (Pa s)

$\theta \quad$ Angle of the feed flow

$\vartheta_{\text {eff }} \quad$ Effective velocity $\left(\mathrm{m} \mathrm{s}^{-1}\right)$

$\rho_{\mathrm{f}} \quad$ Feed density $\left(\mathrm{kg} \mathrm{m}^{-3}\right)$ 


\subsection{References}

[1] J. Schwinge, P.R. Neal, D.E. Wiley, D.F. Fletcher, A.G. Fane, Spiral wound modules and spacers: Review and analysis, Journal of Membrane Science, 242 (2004) 129-153.

[2] V.t. Geraldes, V. Semião, M.N. de Pinho, Flow management in nanofiltration spiral wound modules with ladder-type spacers, Journal of Membrane Science, 203 (2002) 87-102.

[3] A. Cassano, A. Mecchia, E. Drioli, Analyses of hydrodynamic resistances and operating parameters in the ultrafiltration of grape must, Journal of Food Engineering, 89 (2008) 171-177.

[4] A. Versari, R. Ferrarini, G.P. Parpinello, S. Galassi, Concentration of Grape Must by Nanofiltration Membranes, Food and Bioproducts Processing, 81 (2003) 275-278.

[5] A. Rektor, Pilot plant RO-filtration of grape juice, Separation and Purification Technology, 57 (2007) 473.

[6] N. García-Martín, S. Perez-Magariño, M. Ortega-Heras, C. González-Huerta, M. Mihnea, M.L. González-Sanjosé, L. Palacio, P. Prádanos, A. Hernández, Sugar reduction in musts with nanofiltration membranes to obtain low alcohol-content wines, Separation and Purification Technology, 76 (2010) 158-170.

[7] N. García-Martín, L. Palacio, P. Prádanos, A. Hernández, M. Ortega-Heras, S. Pérez-Magariño, D.C. González-Huerta, Evaluation of several ultra- and nanofiltration membranes for sugar control in winemaking, Desalination, 245 (2009) 554-558.

[8] N. Garcia-Martin, S. Perez-Magarino, M. Ortega-Heras, C. Gonzalez-Huerta, M. Mihnea, M.L. Gonzalez-Sanjose, L. Palacio, P. Pradanos, A. Hernandez, Sugar reduction in white and red musts with nanofiltration membranes, Desalination and water treatment, 27 (2011) 167-174.

[9] R. Mira de Orduña, Climate change associated effects on grape and wine quality and production, Food Research International, 43 (2010) 1844-1855.

[10] C. Salgado, L. Palacio, F.J. Carmona, A. Hernández, P. Prádanos, Influence of low and high molecular weight compounds on the permeate flux decline in nanofiltration of red grape must, Desalination, 315 (2013) 124-134.

[11] C. Salgado, F.J. Carmona, L. Palacio, P. Prádanos, A. Hernández, Evaluation of nanofiltration membranes for sugar reduction in red grape must, in: EUROMEMBRANE 2012, London, UK, 2012.

[12] J.M. Dickson, J. Spencer, M.L. Costa, Dilute single and mixed solute systems in a spiral wound reserve osmosis module Part I: Theoretical model development, Desalination, 89 (1992) 63-88. 
[13] C.P. Koutsou, S.G. Yiantsios, A.J. Karabelas, Direct numerical simulation of flow in spacer-filled channels: Effect of spacer geometrical characteristics, Journal of Membrane Science, 291 (2007) 53-69.

[14] G. Schock, A. Miquel, Mass transfer and pressure loss in spiral wound modules, Desalination, 64 (1987) 339-352.

[15] C.P. Koutsou, S.G. Yiantsios, A.J. Karabelas, Numerical simulation of the flow in a plane-channel containing a periodic array of cylindrical turbulence promoters, Journal of Membrane Science, 231 (2004) 81-90

[16] G.E. Karniadakis, B.B. Mikic, A.T. Patera, Minimum-dissipation transport enhancement by flow destabilization: Reynolds' analogy revisited, Journal of Fluid Mechanics, 192 (1988) 365-391.

[17] L. Zovatto, G. Pedrizzetti, Flow about a circular cylinder between parallel walls, Journal of Fluid Mechanics, 440 (2001) 1-25.

[18] C.P. Koutsou, S.G. Yiantsios, A.J. Karabelas, A numerical and experimental study of mass transfer in spacer-filled channels: Effects of spacer geometrical characteristics and Schmidt number, Journal of Membrane Science, 326 (2009) 234-251.

[19] D. Van Gauwbergen, J. Baeyens, Macroscopic fluid flow conditions in spiral-wound membrane elements, Desalination, 110 (1997) 287-299.

[20] V. Geraldes, M.D. Afonso, Prediction of the concentration polarization in the nanofiltration/reverse osmosis of dilute multi-ionic solutions, Journal of Membrane Science, 300 (2007) 20-27.

[21] A.A. Kozinski, E.N. Lightfoot, Ultrafiltration of proteins in stagnation flow, AIChE Journal, 17 (1971) 81-85.

[22] R.L. Goldsmith, Macromolecular Ultrafiltration with Microporous Membranes, Industrial \& Engineering Chemistry Fundamentals, 10 (1971) 113-120

[23] G. Jonsson, Boundary layer phenomena during ultrafiltration of dextran and whey protein solutions, Desalination, 51 (1984) 61-77.

[24] J.G. Wijmans, S. Nakao, C.A. Smolders, Flux limitation in ultrafiltration: Osmotic pressure model and gel layer model, Journal of Membrane Science, 20 (1984) 115124.

[25] P. Pradanos, J.I. Arribas, A. Hernandez, Flux Limiting Factors in Cross-flow Ultrafiltration of Invertase through an Asymmetric Inorganic Membrane, Separation Science and Technology, 28 (1993) 1899-1911.

[26] P. Prádanos, J. de Abajo, J.G. de la Campa, A. Hernández, A comparative analysis of flux limit models for ultrafiltration membranes, Journal of Membrane Science, 108 (1995) 129-142. 
[27] R.C. Kuhn, F. Maugeri Filho, V. Silva, L. Palacio, A. Hernández, P. Prádanos, Mass transfer and transport during purification of fructooligosaccharides by nanofiltration, Journal of Membrane Science, 365 (2010) 356-365.

[28] P. Prádanos, J.I. Arribas, A. Hernández, Retention of proteins in cross-flow UF through asymmetric inorganic membranes, AIChE Journal, 40 (1994) 1901-1910.

[29] M.W. Chudacek, A.G. Fane, The dynamics of polarisation in unstirred and stirred ultrafiltration, Journal of Membrane Science, 21 (1984) 145-160.

[30] L.J. Zeman, Adsorption effects in rejection of macromolecules by ultrafiltration membranes, Journal of Membrane Science, 15 (1983) 213-230.

[31] J.H. Hanemaaijer, T. Robbertsen, T. Van Den Boomgaard, C. Olieman, P. Both, D.G. Schmidt, Characterization of clean and fouled ultrafiltration membranes, Desalination, 68 (1988) 93-108.

[32] W.R. Bowen, J.I. Calvo, A. Hernández, Steps of membrane blocking in flux decline during protein microfiltration, Journal of Membrane Science, 101 (1995) 153-165.

[33] M.N.A. Seman, M. Khayet, N. Hilal, Nanofiltration thin-film composite polyester polyethersulfone-based membranes prepared by interfacial polymerization, Journal of Membrane Science, 348 (2010) 109-116.

[34] P. Prádanos, A. Hernández, J.I. Calvo, F. Tejerina, Mechanisms of protein fouling in cross-flow UF through an asymmetric inorganic membrane, Journal of Membrane Science, 114 (1996) 115-126.

[35] J.C. Schippers, J. Verdouw, The modified fouling index, a method of determining the fouling characteristics of water, Desalination, 32 (1980) 137-148.

[36] K. Listiarini, W. Chun, D.D. Sun, J.O. Leckie, Fouling mechanism and resistance analyses of systems containing sodium alginate, calcium, alum and their combination in dead-end fouling of nanofiltration membranes, Journal of Membrane Science, 344 (2009) 244-251.

[37] K. Listiarini, D.D. Sun, J.O. Leckie, Organic fouling of nanofiltration membranes: Evaluating the effects of humic acid, calcium, alum coagulant and their combinations on the specific cake resistance, Journal of Membrane Science, 332 (2009) 56-62.

[38] D.C. Sioutopoulos, S.G. Yiantsios, A.J. Karabelas, Relation between fouling characteristics of RO and UF membranes in experiments with colloidal organic and inorganic species, Journal of Membrane Science, 350 (2010) 62-82.

[39] D.C. Sioutopoulos, A.J. Karabelas, S.G. Yiantsios, Organic fouling of RO membranes: Investigating the correlation of $\mathrm{RO}$ and UF fouling resistances for predictive purposes, Desalination, 261 (2010) 272-283. 
[40] J.S. Vrouwenvelder, C. Picioreanu, J.C. Kruithof, M.C.M. van Loosdrecht, Biofouling in spiral wound membrane systems: Three-dimensional CFD model based evaluation of experimental data, Journal of Membrane Science, 346 (2010) 71-85

[41] OIV, Compendium of International Methods of Wine and Must Analysis, OIV, Paris, 2011.

[42] J. Hidalgo - Togores, Calidad del vino desde el viñedo, Mundi- Prensa, Madrid, 2006.

[43] C.A. Zuritz, E.M. Puntes, H.H. Mathey, E.H. Pérez, A. Gascón, L.A. Rubio, C.A. Carullo, R.E. Chernikoff, M.S. Cabeza, Density, viscosity and coefficient of thermal expansion of clear grape juice at different soluble solid concentrations and temperatures, Journal of Food Engineering, 71 (2005) 143-149.

[44] G. Foley, D.M. Malone, F. MacLoughlin, Modelling the effects of particle polydispersity in crossflow filtration, Journal of Membrane Science, 99 (1995) 77-88 


\section{Chapter 6}

\section{Alcohol reduction in red and white wines by nanofiltration of musts before fermentation}

Camila M. Salgado ${ }^{1}$, Encarnación Fernández-Fernández, Laura Palacio ${ }^{1}$, Antonio Hernández ${ }^{1}$ and Pedro PrádanoS ${ }^{1}$.

${ }^{1}$ Grupo de superficies y Materiales porosos (SMAP, UA-UVA-CSIC), Dpto. de Física Aplicada, Facultad de Ciencias, Universidad de Valladolid, 47011 Valladolid, Spain. ${ }^{2}$ Área de Tecnología de Alimentos, E.T.S. de Ingenierías Agrarias, Universidad de Valladolid, Campus La Yutera, Avda. Madrid 44, 34071 Palencia, Spain.

This chapter has been accepted for publication in the journal:

Food and Bioproducts Processing.

DOI: 10.1016/j.fbp.2015.09.005 



\section{Chapter 6. Alcohol reduction in red and white wines by nanofiltration of musts before fermentation}

\section{Abstract}

A consequence of global warming is the early ripening of grapes which promotes, among others, a higher fermentable sugar (glucose and fructose) content. This leads to wines with an alcoholic degree higher than desired.

In this work, the main differences between red grape must nanofiltration at laboratory and pilot plant scale were studied in order to perform the scale-up of a nanofiltration process to reduce the sugar content. For this, previous results of the nanofiltration of commercial red must using the SR3 membrane in a flat sheet crossflow module were compared with those obtained for the filtration of natural red must using the same membrane in a spiral wound module at two different applied pressures.

The aim of this publication is to analyze the main differences between red grape must nanofiltration at laboratory and at pilot plant scale.

Results showed that the flow destabilization and eddy promotion caused by spacers in the spiral wound module mitigate the rate at which the cake thickens and compacts on the membrane surface. This causes a less sharp flux decrease, less variable sugars rejection and osmotic pressure difference. Moreover, higher applied pressure promotes a higher membrane fouling and osmotic pressure that worsen the flux decay.

Keywords:

Red grape must, Nanofiltration, Scale-up, Spiral wound module, Sugar content reduction 


\subsection{Introduction}

Over the last years, due to global warming, observations from various world winemaking regions have provided evidence of modified vine development and fruit maturation patterns. Among the most important climate change-related effects there is an increased grape sugar concentration that leads to high wine alcohol levels, lower acidities and modification of varietal aroma compounds [1]. Premature grape harvest and winemaking should affect the final wine quality, because the acidic and phenolic maturity should not be fully achieved [2] leading to more acid and less colored wines. A commendable oenological practice establishes that the quality of wines depends essentially on the maturity of phenolic components contained in the grape berries. Since phenolic maturity is directly linked to a high sugar concentration, grapes are being picked having high potential alcohol content, up to 17\%, with low acidity [3].

But in some countries, as USA, wine producers have to struggle with a supplementary tax added to beverages with alcohol content over $14.5 \%$. Moreover, this over maturity leads to difficulties in wine making as some difficulties appear in alcoholic fermentation and in microbiological stabilization. It also causes a gustatory disequilibrium since the strengthening of warm sensation in the mouth could mask the fruity aromas and taste of wine. Meanwhile, consumers show preference and demand wines with less alcohol content (between 9 and 13\%), tendency reinforced by the new social trends of limiting alcohol consumption [3-5].

Therefore, in order to produce a full flavored wine, the harvest should be carried out in the optimum ripeness of the fruits and then innovative techniques to control sugars in musts should be applied.

In order to use a mild and highly specific technology, membranes are a good election. Recently, the OIV introduced in the "International Code of Oenological practices" the application of membrane techniques for the treatment of musts and wine in order to enable the selective holding back or passing of some compounds [6].

If the molecular weight of sugars in must is taken into account, nanofiltration (NF) seems to be the most appropriate technique to control their concentration [7]. In our previous work [8], several experiments were performed aiming to select the most appropriate NF membrane for sugar control in grape must. Here, the performance on must NF of 3 flat sheet membranes was compared: NF270 (Dow Filmtec), HL (GE) and SR3 (Koch Membrane System). The results obtained showed that the HL and SR3 membranes were the most appropriate to reduce the content of sugar of red must. Specifically SR3 showed the best passage of sugar and less fouling. As a continuation 
of the mentioned study, the SR3 membrane was successfully used for sugar control in grape must at a higher scale using a spiral wound module (SWM) [9].

The scope of the present study is to select the most appropriate NF technique to reduce the alcohol content of wines approximately 2 degrees by controlling the sugar content of the grape must before its fermentation. For that purpose the performance of single- stage and two-stage NF processes using a SWM unit were compared. This was tested by treating musts coming from two Spanish varieties of grapes, a white one (Verdejo) and a red one (Garnacha).

\subsection{Theory}

When the overall filtration process is taken into account, the permeate flux per unit of membrane area can be written in terms of the applied transmembrane pressure, $\Delta p$, the osmotic pressure gradient, $\Delta \pi$, the viscosity of the solution, $\eta$, and the system resistance. This is the sum of the membrane resistance, $R_{\mathrm{m}}$, plus a series of terms that depend on the fouling caused by the solute and the membrane itself, $R_{\mathrm{f}}$ [10-13]. Thus the permeate flux can be written as

$$
J_{v}=\frac{\Delta p-\Delta \pi}{\eta\left(R_{m}+R_{f}\right)}
$$

The efficiency of a membrane is determined by its true retention, $R$, which is defined as

$$
R_{i}=1-\frac{C_{\mathrm{p}, i}}{C_{\mathrm{m}, i}} \quad(i=1,2 \ldots N)
$$

for the $i$-th component present as solute in the feed. Here $C_{\mathrm{m}, i}$ is the concentration of the $\mathrm{i}$-th component on the membrane active layer and $C_{\mathrm{p}, i}$ the permeate concentration of the i-th component. One of the methods to calculate the experimentally inaccessible concentration $C_{\mathrm{m}, i \cdot}$ is the use of the Film Theory of concentration polarization. This model is based on the use of the mass transfer coefficient, $K_{\mathrm{m}, i}$ in order to describe the solute transport in the membrane active layer $[14,15]$ as

$$
C_{\mathrm{m}, i}=C_{\mathrm{p}, i}+\left(C_{0, i}-C_{\mathrm{p}, i}\right) e^{\left(J_{\mathrm{v}} / K_{m, i}\right)}
$$


here, $J_{v}$ is the flux through the membrane; $C_{0, i}$ and $K_{m, i}$ are the feed concentration and the mass transfer coefficient of the $i$-th component respectively.

The hydrodynamics and mass transport in a spiral wound module are critically influenced by the presence of the spacer material in the feed channel. The appropriate equations for the spiral wound unit and used in the present study have been explained in detail in our previous work [9] and according to it $K_{m, l}$ can be evaluated as [16-18]

$$
K_{m, i}=0.14 \times D_{i}^{0.58} x d_{h}^{-0.36} x v_{e f f}^{0.64} \times \rho_{f}^{0.22} x \eta_{f}^{-0.22}
$$

where $D_{i}$ is the diffusion coefficient of the $i$-th component, $d_{h}$ and $v_{\text {eff }}$ are the hydraulic diameter and the effective velocity characteristic of the feed channel respectively, and $\eta_{f}$ and $\rho_{f}$ stand for the viscosity and density of the feed respectively.

Taking into account that the membrane is semipermeable, the $K_{\mathrm{m}, i}$ calculated using Eq. 4, that should be valid for an impenetrable wall, need to be corrected to $K_{m, i}^{s}$ according to Geraldes and Afonso [19]:

$$
K_{m, i}^{s}=K_{m, i}\left[\left(\frac{J_{v}}{K_{m, i}}\right)+\left(\frac{J_{v} / K_{m, i}}{\exp \left\{J_{v} / K_{m, i}-1\right\}}\right)\right] \text { for } \quad J_{v} / K_{m, i} \leq 1
$$

\subsection{Materials and Methods}

\subsubsection{Membrane and experimental set-up}

Grape must filtrations were performed in a pilot plant scale unit with a NF SWM. The experimental set-up used is shown in Figure 6.1.

It consists in a feed vessel, with a cryogenic unit to assure that the feed's temperature is kept at $16 \stackrel{\circ}{\circ}$. The feed is extracted from the thermostated reservoir by means of a regulatable piston pump Hydra-Cell G03. Two pressure transducers are placed before and after the SWM to measure the inlet and outlet pressure. In order to adjust manually the pressure inside the module a needle valve is placed at the exit of the unit. Cross flow is adjusted through this valve and the speed control of the pump. The retentate flow rate is measured with a flowmeter ranging from 0 to $10 \mathrm{~L} / \mathrm{min}$. In order to decrease the retentate temperature a heat exchanger was placed before its return to the feed vessel. The permeate flux was monitored using a three-tube flow system with flow capacity from 0 to $10 \mathrm{~L} / \mathrm{min}$. 


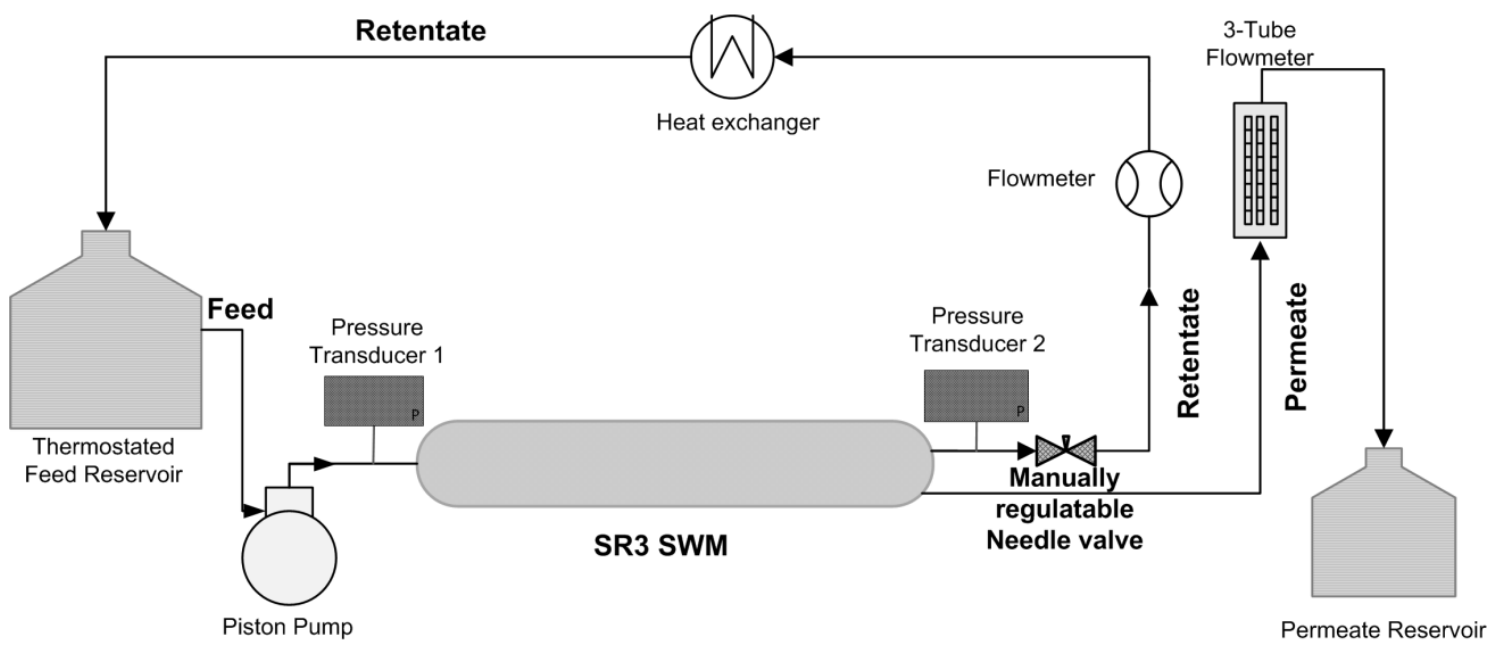

Figure 6.1. Scheme of the experimental device used in the Nanofiltration processes

The membrane used for NF was a KMS SR3 (reference 3839 SR3- NYV), made and commercialized by Koch Membrane Systems. As mentioned, the selection of the SR3 membrane was based on previous experiments testing different nanofiltration membranes in flat sheet configuration using commercial musts [8]. The main characteristics of the membrane and SWM have already been exposed in our previous study [9], they are summarized in the supplementary material (see Table S6.1).

\subsubsection{Grape musts}

Two different grape must varieties were used, one white and one red, called Verdejo and Garnacha respectively. Both varieties were cultivated in the experimental vineyard of the Agriculture Technology Institute of Castilla y León (experimental field of Zamadueñas, Valladolid, Spain) from 2012 vintage. Both, grapes, white and red, were transported in plastic boxes of $15 \mathrm{~kg}$ to the experimental wine cellar of the Agricultural Engineering School (University of Valladolid, Palencia, Spain), where the musts were elaborated.

\section{Garnacha red must}

After the reception, about $100 \mathrm{~kg}$ of Garnacha grapes were destemmed and crushed and potassium metabisulphite was added $\left(80 \mathrm{mg} / \mathrm{L}\right.$ of $\left.\mathrm{SO}_{2}\right)$ in order to prevent oxidation or spoilage caused by bacteria. The must was obtained by drawing off, without press. In this case, the solid parts (crushed mass which consist of the grape skins, seeds, remaining must and so forth), were cold-stored at $4{ }^{\circ} \mathrm{C}$ in airtight plastic boxes for ulterior addition to musts for the fermentation after nanofiltration. The must 
was filtered first through $3 \mu \mathrm{m}$ and then through $0.8 \mu \mathrm{m}$ cellulose filter plates in order to prevent fast membrane clogging and to make the nanofiltration easier.

\section{Verdejo white must}

In this case, nearly $200 \mathrm{~kg}$ of Verdejo grapes were destemmed, crushed, sulphited and pressed to obtain the respective must. Potassium metabisulphite was added $\left(80 \mathrm{mg} / \mathrm{L}\right.$ of $\mathrm{SO}_{2}$ ) with the same purpose as for red must. Pectolytic enzymes (10 $\mathrm{mg} / \mathrm{L}$ of Enozym Altair, Agrovin) were added to enhance first clarification.

The cleared must was filtered through $0.8 \mu \mathrm{m}$ cellulose filter plates in order prevent ulterior membrane fouling and thereby facilitating the nanofiltering process.

The main oenological parameters of the pre-filtered red and white must before the nanofiltration process are given in the first column (as control must) of the Tables 6.2 and6.3, respectively.

The portions of the musts that were going to be nanofiltered were transported in $35 \mathrm{~L}$ stainless steel vessels to the Laboratory of Membrane Processes of the Faculty of Science (University of Valladolid, Valladolid, Spain). The remaining volumes of musts were cold-stored at $4 \stackrel{\circ}{\circ} \mathrm{C}$ in airtight vessels and kept as control musts in the cold chamber of the Agricultural Engineering College (University of Valladolid, Palencia, Spain).

\subsubsection{Procedure}

In order to select the most appropriate nanofiltration process for sugar reduction in musts, different techniques were studied. In the case of the white must, two nanofiltrations were carried out: a single-stage method and a two- stage one. For the red must a two-stage nanofiltration was analyzed.

Before using the SR3 module, it had to be conditioned following successive cleaning steps to enhance its performance (refer to Fig. S6.1 of the supplementary material for more detail).

All must filtrations were carried out in a batch concentration mode. Permeate was sent to the thermostated permeate vessel in order to collect it and the retentate was recirculated to the thermostated feed vessel.

Between filtrations, membrane setting was carried out and water permeability was determined.

After all filtration processes, a cleaning procedure, according to manufacturer's instructions (refer to Fig. S6.2 of the supplementary material), was carried out and the final water permeability of the membrane was determined. 


\subsubsection{Two-stage Nanofiltrations}

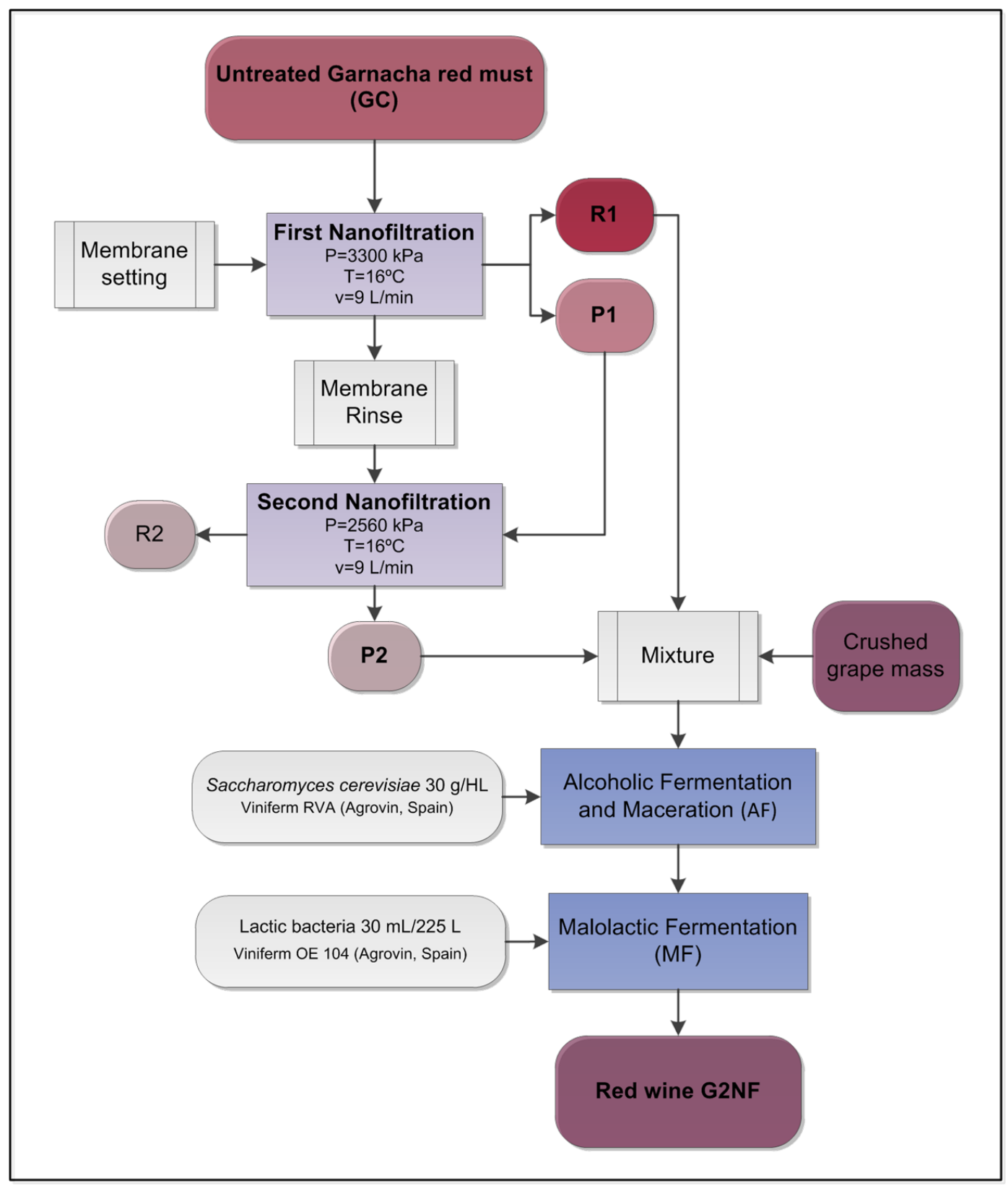

Figure 6.2. Scheme of the procedure carried out for the Garnacha red must two-stage Nanofiltration and ulterior fermentations

$25 \mathrm{~L}$ of must (red and white) were treated in a double nanofiltration in the following steps:

- Nanofiltration (first stage) of untreated must (C) providing a permeate with a medium sugar content (P1) and a sugar rich retentate (R1). The later also contains the main portion of the high molecular weight compounds such as polyphenols, polysaccharides and proteins. 
- Nanofiltration (second stage) of the first permeate (P1) providing a retentate (R2) and a second permeate (P2) with a lower sugar content.

- For both musts, red and white, the second permeate (P2) was mixed with the first retentate $(R 1)$ in appropriate proportions to produce the intended moderate reduction in the alcohol degree of the final wine. This mixture preserves the specific grape features linked to the high molecular weight components retained in $\mathrm{R} 1$.

A scheme that describes briefly each two-stage nanofiltration procedure and operating conditions is depicted in Figure 6.2 for the Garnacha red must and in Figure $6.3 a$ for the Verdejo white must.

\subsubsection{Single-stage Nanofiltration}

$25 \mathrm{~L}$ of white must were treated using one nanofiltration stage. Figure $6.3 \mathrm{~b}$ shows a scheme of the single-stage nanofiltration process carried out.

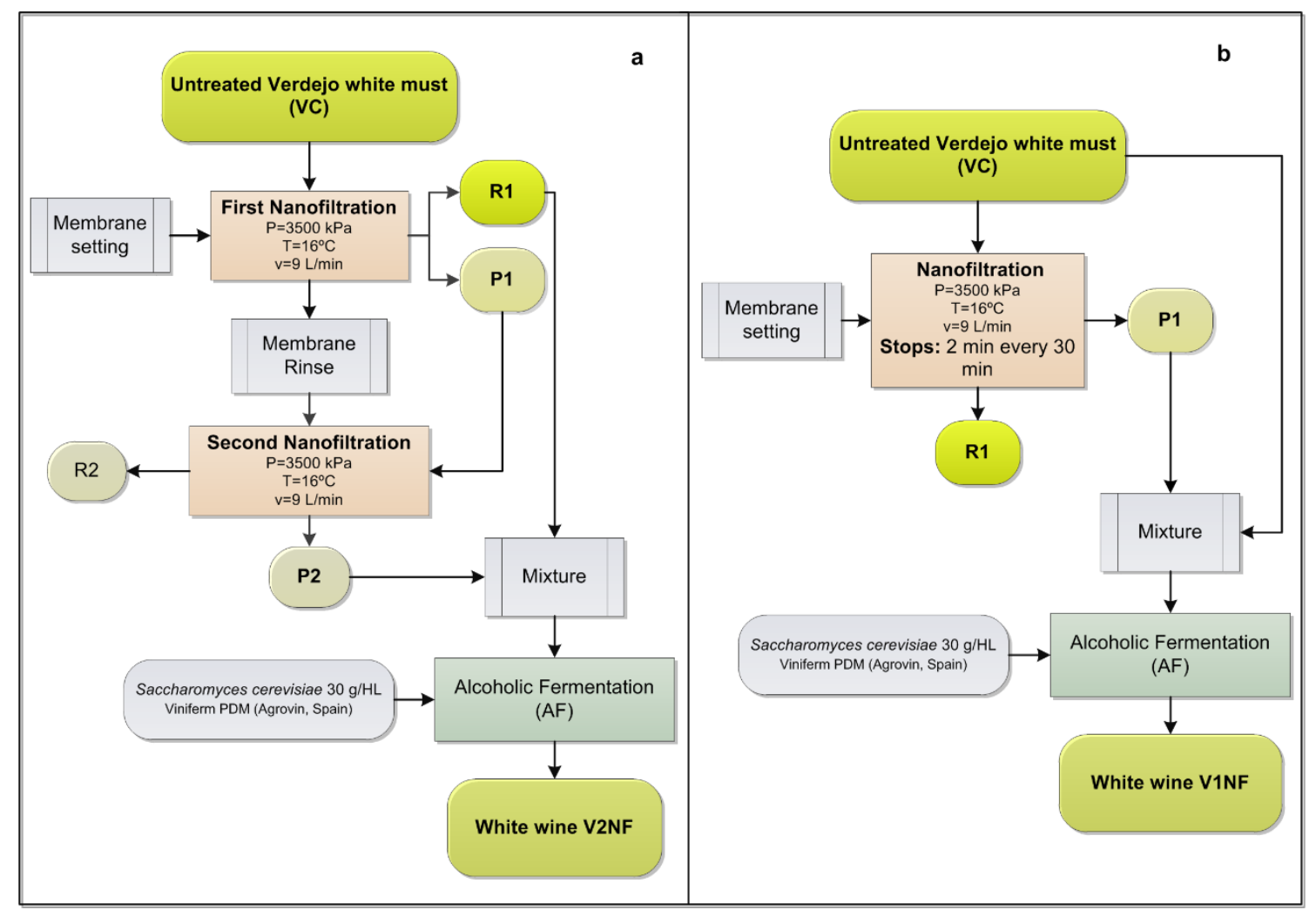

Figure 6.3. Scheme of the Nanofiltration procedures carried out for the Verdejo white must and ulterior fermentation. a) two-stage and b) single-stage nanofiltration

During this procedure 2-minutes-stops were performed every 30 minutes by manually opening the needle valve of the retentate loop, at the exit of the SWM (see 
Figure 6.1). Thereby, the applied pressure inside the module is zero. In this way, only the osmotic pressure acts as driving force creating a backflush of permeate to the retentate. This overturn of the flow promotes shear, which may affect the deposition and detachment behavior of the fouling species on the membrane surface.

This process provides a sugar rich retentate $(\mathrm{R} 1)$ and a permeate $(\mathrm{P} 1)$ with a low sugar content.

After this, permeate (P1) was blended with untreated white must (VC) in adequate proportions to create a mixture with a similar sugar content as in the twostage process.

\subsubsection{Winemaking process}

The elaboration of wines was carried out at the experimental winery of the Agricultural Engineering School (University of Valladolid, Palencia, Spain). Both wine varieties, red and white, were manufactured following the corresponding traditional procedure (detailed in Fig. S6.3 of the supplementary material).

Three different Garnacha red wines were elaborated: A control made from the control must (GC) and two low alcohol content wines obtained from the mixture of musts (P2+R1): G2NF1 and G2NF2. These low alcohol samples represent the duplicate of the fermentation of the same blend of musts.

Also, three different Verdejo white wines were manufactured: A control obtained from the control must (VC), and two low alcohol content wines: one made from the mixture proceeding from the single-stage nanofiltration $(P 1+C): V 1 N F$ and one produced from the mixture $(\mathrm{P} 2+\mathrm{R} 1)$ obtained from the two-stage nanofiltration process: V2NF.

\subsubsection{Analytical methods}

Musts were analyzed before and after the filtration process according to the principles and methods summarized in Table 6.1.

The chromatographic system used consisted in an HPLC apparatus from Waters with a Refractive Index detector Waters 2414, an isocratic pump Waters 1515, the Waters 1707 Autosampler, and a thermostated column compartment together with the software Breeze 2. A Supelco Supelcogel Pb guard column and column were used for the sugars (glucose and fructose) separation and a Shodex DE-413 guard column and column for malic and tartaric acid detection. 
Total and Free $\mathrm{SO}_{2}$ were determined by idometry according to the Ripper method [20]. This technique was automated by means of an SO2- Matic 23 apparatus from Crison.

Alcohol Degree of wines was measured by ebulliometry [22] using a Barus apparatus from GAB System.

UV/Vis spectrophotometric methods were performed using the UV/Vis spectrophotometer (Lan Optics 2000 UV, Labolan, Spain).

Table 6.1. Methods used for the determination of some oenological parameters of musts.

\begin{tabular}{|c|c|c|}
\hline Parameter & Principle & Method \\
\hline Glucose and & Ion exchange & \multirow{2}{*}{ HPLC } \\
\hline Fructose & Chromatography & \\
\hline Tartaric and & \multirow{2}{*}{ Chromatography } & \multirow{2}{*}{ HPLC } \\
\hline Malic Acid & & \\
\hline $\mathrm{pH}$ & Potentiometry & pH-meter \\
\hline Volatile acidity & Acid- base titration & García-Tena $^{a}$ \\
\hline Total acidity & Potentiometric titration & OIV $^{b}$ \\
\hline $\mathrm{SO}_{2} \mathrm{~T}$ and $\mathrm{SO}_{2} \mathrm{~F}$ & lodometry & Ripper automated \\
\hline Alcoholic degree & Ebullometry & Barus apparatus $^{c}$ \\
\hline Total & \multirow{2}{*}{ UV absorbance } & \multirow{2}{*}{ UV/Vis spectrophotometry } \\
\hline Polyphenols & & \\
\hline Anthocyanins & Vis absorbance & UV/Vis spectrophotometry ${ }^{d}$ \\
\hline Color & Vis absorbance & UV/Vis spectrophotometry \\
\hline
\end{tabular}

\subsubsection{Consumer sensory test}

Sensory evaluation of the wines was conducted with 48 consumer volunteers from 18 to 65 years old of various socioeconomic backgrounds. A total of $68.75 \%$ of the consumers were male and $85.42 \%$ were between 18 and 34 years of age.

Consumer tests were carried out in the Sensory Science Laboratory of the Agricultural Engineering College at the University of Valladolid, Palencia (Spain), in individual booths.

The sensory analysis session for each panelist consisted in doing first the acceptability test of the white wine samples and then of the red wine samples. Consumers tasted the samples served sequential monodically. Samples were 
presented in glasses coded with 3-digit random numbers and served in a randomized order. Water and crackers were available for rinsing.

Here, the wines were evaluated on the basis of the acceptance of the sensory descriptors color, odor, flavor, persistence and overall liking on a 9-point hedonic scale. The scale of values ranged from "like extremely" to "dislike extremely" corresponding to the highest and lowest scores of 9 and 1, respectively.

Principal component analysis (PCA) was used to know the effect of the different filtrations on the sensorial and physicochemical characteristics of the wines. Consumer sensory data collected from the acceptability test were subjected to PCA in order to see which the favorite wines were. PCA was performed with the correlation matrix (derived from the data matrix). SPSS for Windows (version 20.0) was used for data processing [25].

\subsection{Results and discussion}

\subsubsection{Nanofiltration processes}

As mentioned, water permeability $\left(L_{p}\right)$ and resistance $\left(R_{m}\right)$ of the SWM were determined before each filtration process to control its performance. The values obtained are given in Table S6.2 of the supplementary material.

Figure 6.4 depicts the kinetics of the permeate flux of the three filtration processes.
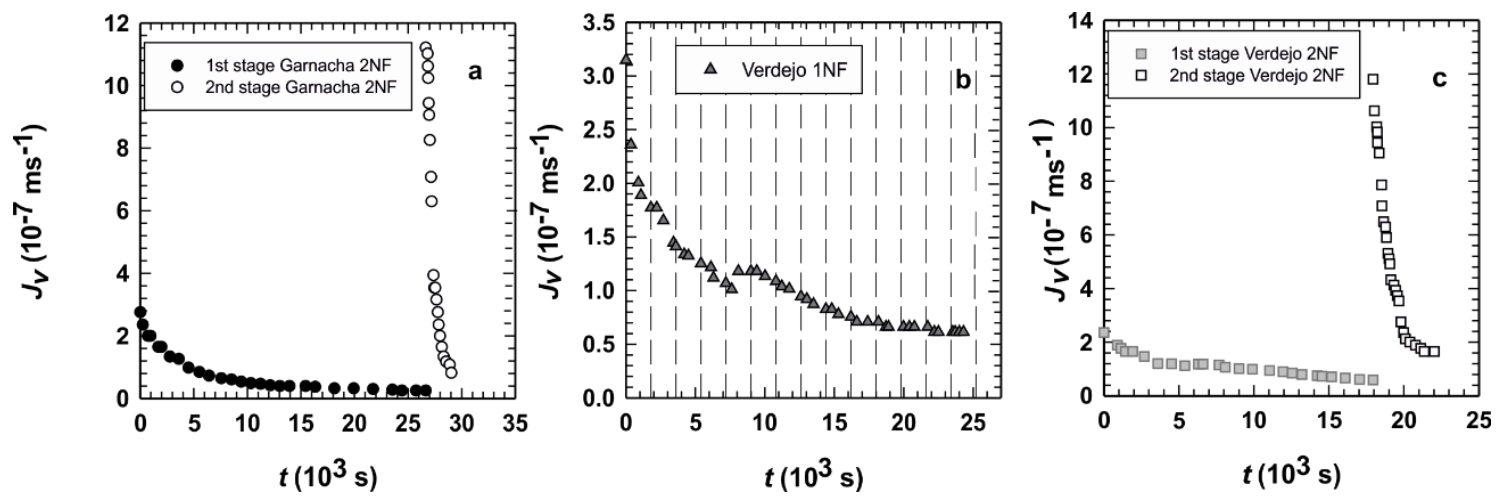

Figure 6.4. Kinetics of the permeate flux of the three filtration processes. (a) and (c) for the two-stage filtration processes, of red and white must respectively. (b) shows the kinetics of the white permeate must during the single-stage NF process. Dashed lines represent the 2minutes-stops with osmotic backflushing 
Figure 6.5 compares the filtration processes of the red and white musts during the first and second stages (Figure 6.5a and b respectively), in terms of the initial permeate flux $\left(J_{v} / J_{v, 0}\right)$. Thus the influence of the initial membrane fouling is avoided.
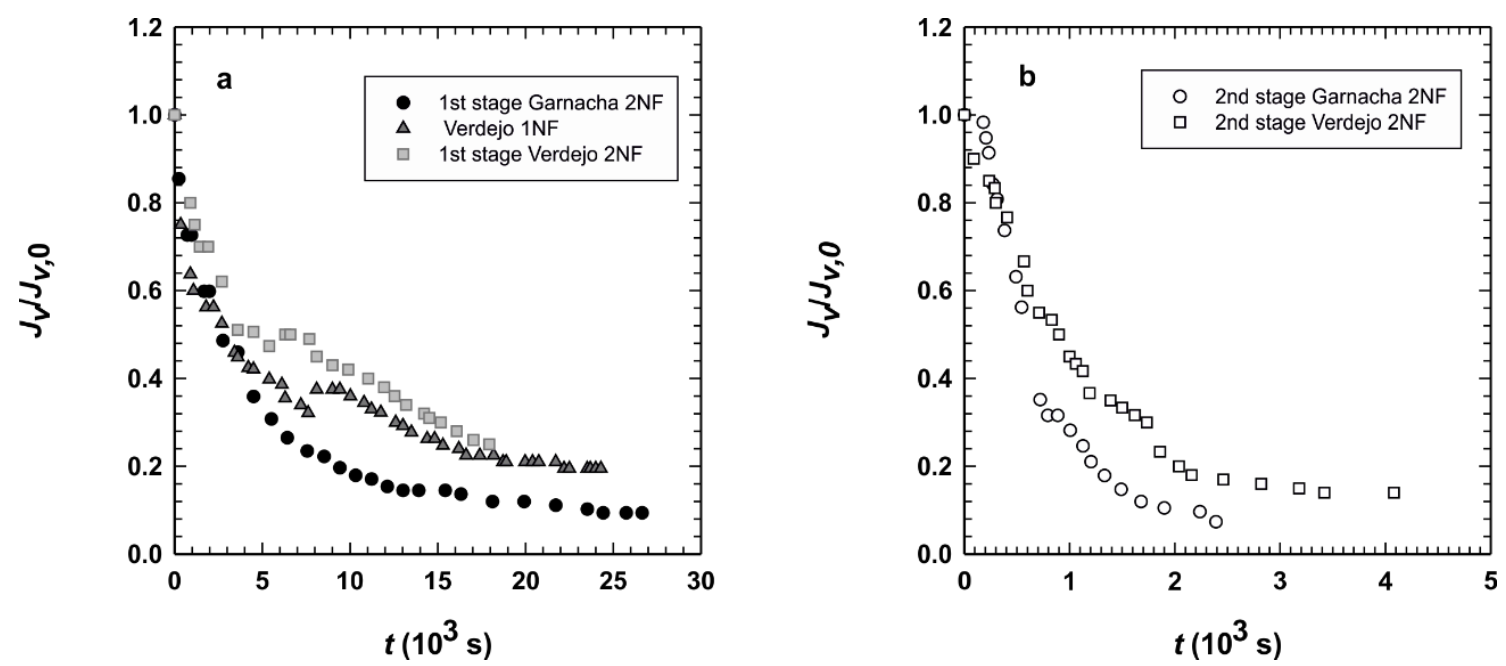

Figure 6.5. Comparison of the filtration processes of the red and white musts during the first (a) and second stage (b), in terms of the initial permeate flux $\left(J_{v} / J_{v, 0}\right)$

According to Eq. (1), the factors that would mainly promote the flux decline during the first- stage of nanolfiltration (due to the presence of high molecular weight compounds in the feed) are:

1. Formation and thickening of the cake layer on the membrane surface $\left(R_{f}\right)$.

2. Increase of the viscosity $(\eta)$ of the fluid that goes through the membrane pores.

3. Reversible or irreversible fouling of the membrane during the process $\left(R_{m}\right)$.

As expected, the contribution of these factors is more significant in the case of Garnacha red must (see Figure 6.5a) because of its higher concentration of molecules with a molecular weight higher than 300 Da such as polyphenols (see Total polyphenols index in Table 6.2) and proteins (as shown in table S6.1, the molecular weight cut-off of the membrane is $200 \mathrm{Da}$ ). Moreover, the importance of fouling and cake formation is shown in Fig. 6.4a and 6.4c. Here, the initial flow of the first- stage is considerably lower than the initial one of the second-stage, where the feed is mainly composed of low molecular weight molecules.

The permeate flow is also influenced by the osmotic pressure $(\Delta \pi)$ increase (see Eq. (1)) due to the increment of the concentration of small molecules in the retentate, $\left(C_{0}\right)$ and therefore on the membrane active layer $\left(C_{m}\right)$. This contribution should be similar for both musts, since the concentration of small solutes (such as 
glucose, fructose malic and tartaric acids) is similar in both as shown in Tables 6.2 and 6.3. This fact can be mainly appreciated in Figure 6.5b, where the flow kinetics in the second filtration stage is illustrated. Thus the influence of the high molecular weight compounds is avoided.

The effect of the 2-minutes-stops carried out during the single stage NF process of Verdejo must can be assessed in Figure 6.5a. Here, lower permeate flow values than for the two-stage NF process are reached. Apparently, the permeate backflush affects in an unexpected way the deposition of foulants and their attachment on the membrane surface, this is, on the growing cake surface. This agrees with the results obtained by [26]. In their research they studied the influence of shear on cake formation and fouling of reverse osmosis and ultrafiltration membranes. They observed that when applying higher stirring rotation speed (i.e. higher shear) in the dead end filtration cell, lower permeate fluxes were obtained. They attributed this to the formation of a thinner cake. Results suggest that the re-suspension of the deposited molecules promoted by shear leads to a thinner cake or the formation of smaller aggregates. This may have higher resistance to the permeate flux and therefore be more effective in reducing the permeate flow.

The concentration of glucose and fructose was measured for the retentate and permeate for both musts along all filtration stages and processes. $R_{i}$ was calculated according to Eqs.(2) to (5).

Figure 6.6 shows a comparison of the sugars rejection during the first (Figure 6.6a) and the second stages (Figure 6.6b) of filtration of both musts.

It may be observed a slight reduction in the time evolution of the retention for the three processes and also for the 2 stages. This decrease was expected due to the rise of the concentration of sugars in the retentate that finally cross the membrane.

During the first filtration, the retention is higher for the Garnacha must. This is due to the presence of higher amounts of high molecular weight compounds (higher than $300 \mathrm{Da}$ ), which contribute to the membrane fouling and cake formation. As observed in previous works [27], this cake layer formed on the membrane surface acts as a pseudo-membrane that changes both: permeability and selectivity of the overall membrane. In the absence of larger molecules (Figure 6.6b) the phenomena related with cake formation are mitigated. Thus, the sugar retention is similar for the musts obtained from Garnacha and Verdejo varieties, during the second stage.

Figure 6.6a shows that the process in which the stops were carried out (Verdejo $1 \mathrm{NF}$ ) sugars rejection is higher than in the process without them. This suggests that the thinner cake formed, probably composed of smaller aggregates, as mentioned, may be less porous and therefore less permeable to sugars too. 

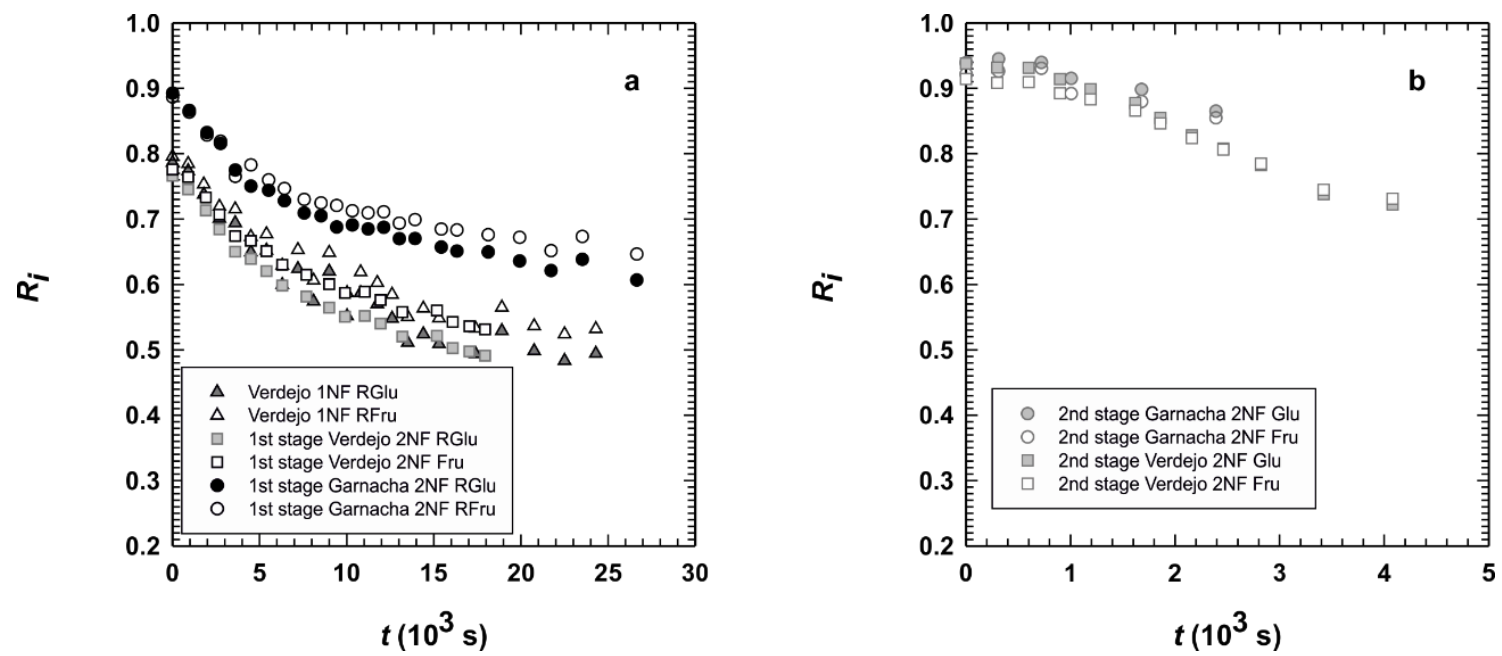

Figure 6.6. Comparison of the sugars rejection during the first (a) and the second stages (b) of filtration of both musts

\subsubsection{Analysis of the filtered musts}

Concentrations of the resultant permeates and retentates were analyzed, for each stage and NF process. Results for the Garnacha red must and for the Verdejo white must are shown in Tables 6.2 and 6.3 respectively. Note that some parameters have not been determined for some samples because they were considered irrelevant.

Results show that the general trend is a high reduction of total sugars in the permeates and an increase in the retentates.

Regarding the effect of NF on the concentration of low molecular weight compounds such as malic and tartaric acid, Tables 6.2 and 6.3 show that the variations are not so significant for these compounds. Furthermore, since the purpose is to produce low alcohol wines, the permeate has to be mixed with untreated must $(P 1+C)$ or with the retentate $(P 2+R 1)$ in adequate proportions before its fermentation. In this way, the reconstructed must will be chemically very similar to the original one but with a lower sugar content and the variation of the other compounds will be reduced. In accordance to the total sugar content of the mixtures, the probable alcoholic degree of the resulting wine can be estimated from tables [20]. In this way, Table 6.2 shows that the blend $(\mathrm{P} 2+\mathrm{R} 1)$ of red musts predicts a $1.67^{\circ}$ reduction of the alcohol content. In the case of white musts (Table 6.3), the mixtures $(P 1+C)$ and $(P 2+R 1)$ predict a decrease by $2.17^{\circ}$ and $1.49^{\circ}$ respectively. In all cases this predictive parameter shows that the alcohol reduction would be around $2^{\circ}$ as intended. Note that the reduction is not exactly the same in all cases due to the difficulty involved in determining the exact proportions of musts to blend. 
Table 6.2. Oenological parameters of Garnacha red musts after the two-stage NF process and of the control must (C).

\begin{tabular}{|c|c|c|c|c|c|c|}
\hline & \multirow{2}{*}{$\begin{array}{l}\text { Control } \\
\text { (VC) }\end{array}$} & \multicolumn{5}{|c|}{ Garnacha two-stage NF } \\
\hline & & P1 & R1 & P2 & R2 & P2+R1 \\
\hline $\begin{array}{c}\text { Glucose } \\
(\mathrm{g} / \mathrm{L})\end{array}$ & $105 \pm 2$ & $27.6 \pm 0.6$ & $135 \pm 3$ & $5.73 \pm 0.13$ & $92 \pm 2$ & $90 \pm 2$ \\
\hline $\begin{array}{c}\begin{array}{c}\text { Fructose } \\
(\mathrm{g} / \mathrm{L})\end{array} \\
\end{array}$ & $106 \pm 4$ & $27.0 \pm 1.0$ & $138 \pm 5$ & $7.5 \pm 0.3$ & $92 \pm 3$ & $93 \pm 3$ \\
\hline $\begin{array}{c}P^{P^{a}} \\
(\% \text { vol) }\end{array}$ & $12.5 \pm 0.3$ & --- & --- & --- & --- & $10.9 \pm 0.3$ \\
\hline $\begin{array}{c}\mathrm{TH}_{2} \\
(\mathrm{~g} / \mathrm{L})\end{array}$ & $4.4 \pm 0.5$ & $3.0 \pm 0.4$ & $4.3 \pm 0.5$ & $1.51 \pm 0.19$ & $\begin{array}{c}4.8 \pm \\
0.6 \\
\end{array}$ & $3.9 \pm 0.5$ \\
\hline $\begin{array}{l}\mathrm{MH}_{2} \\
(\mathrm{~g} / \mathrm{L}) \\
\end{array}$ & $0.59 \pm 0.01$ & $\begin{array}{c}0.53 \pm \\
0.01 \\
\end{array}$ & $0.47 \pm 0.01$ & $0.43 \pm 0.01$ & $\begin{array}{c}0.58 \pm \\
0.01\end{array}$ & $0.49 \pm 0.01$ \\
\hline $\mathrm{pH}$ & $3.02 \pm 0.01$ & ---- & $3.12 \pm 0.01$ & ---- & ---- & $3.19 \pm 0.01$ \\
\hline $\begin{array}{c}\mathrm{TA} \\
\left(\mathrm{gTH}_{2} / \mathrm{L}\right)\end{array}$ & $3.21 \pm 0.01$ & ---- & $3.06 \pm 0.1$ & ---- & ---- & $2.70 \pm 0.14$ \\
\hline TPI & $8.8 \pm 0.3$ & $\begin{array}{c}1.18 \pm \\
0.01\end{array}$ & $12.9 \pm 0.5$ & $0.29 \pm 0.01$ & ---- & $7.93 \pm 0.18$ \\
\hline $\mathrm{Cl}$ & $0.34 \pm 0.04$ & $\begin{array}{c}0.02 \pm \\
0.01\end{array}$ & $0.28 \pm 0.04$ & $\mathrm{~N} / \mathrm{D}$ & $\mathrm{N} / \mathrm{D}$ & $0.20 \pm 0.06$ \\
\hline $\begin{array}{c}\mathrm{AC} \\
(\mathrm{mg} / \mathrm{L})^{\mathrm{b}}\end{array}$ & $63 \pm 3$ & ---- & $91 \pm 7$ & ---- & ---- & $56.9 \pm 1.2$ \\
\hline
\end{tabular}

VC: Control must; P1: permeate of the first stage; R1: retentate of the first stage; P2: permeate of the second stage; R2: retentate of the second stage.

PA: Probable alcoholic degree; TA Total acidity expressed as $\mathrm{g} \mathrm{TH}_{2}$ per liter; $\mathrm{TH}_{2}$ : Tartaric acid, $\mathrm{MH}_{2}$ : Malic acid; TPI: Total Polyphenol Index; Cl: Color Index; AC: Anthocyanins content $\mathrm{N} / \mathrm{D}$ : not detectable

${ }^{a}$ Estimated from tables of the alcoholic degree to be expected on the basis of $16.83 \mathrm{~g}$ sugars from must per $1 \%$ alcohol [20]

${ }^{\mathrm{b}}$ expressed as mg malvidin-3 glycoside per liter

The influence of the NF procedures on the phenolic compounds was measured in terms of the total polyphenols index (TPI) and the color index $(\mathrm{Cl})$, since they are related to the color of must (see Tables 6.2 and 6.3). In the case of the main red musts samples (i.e. GC, R1 and (R1+P2)), the content of anthocyanins was also measured. 


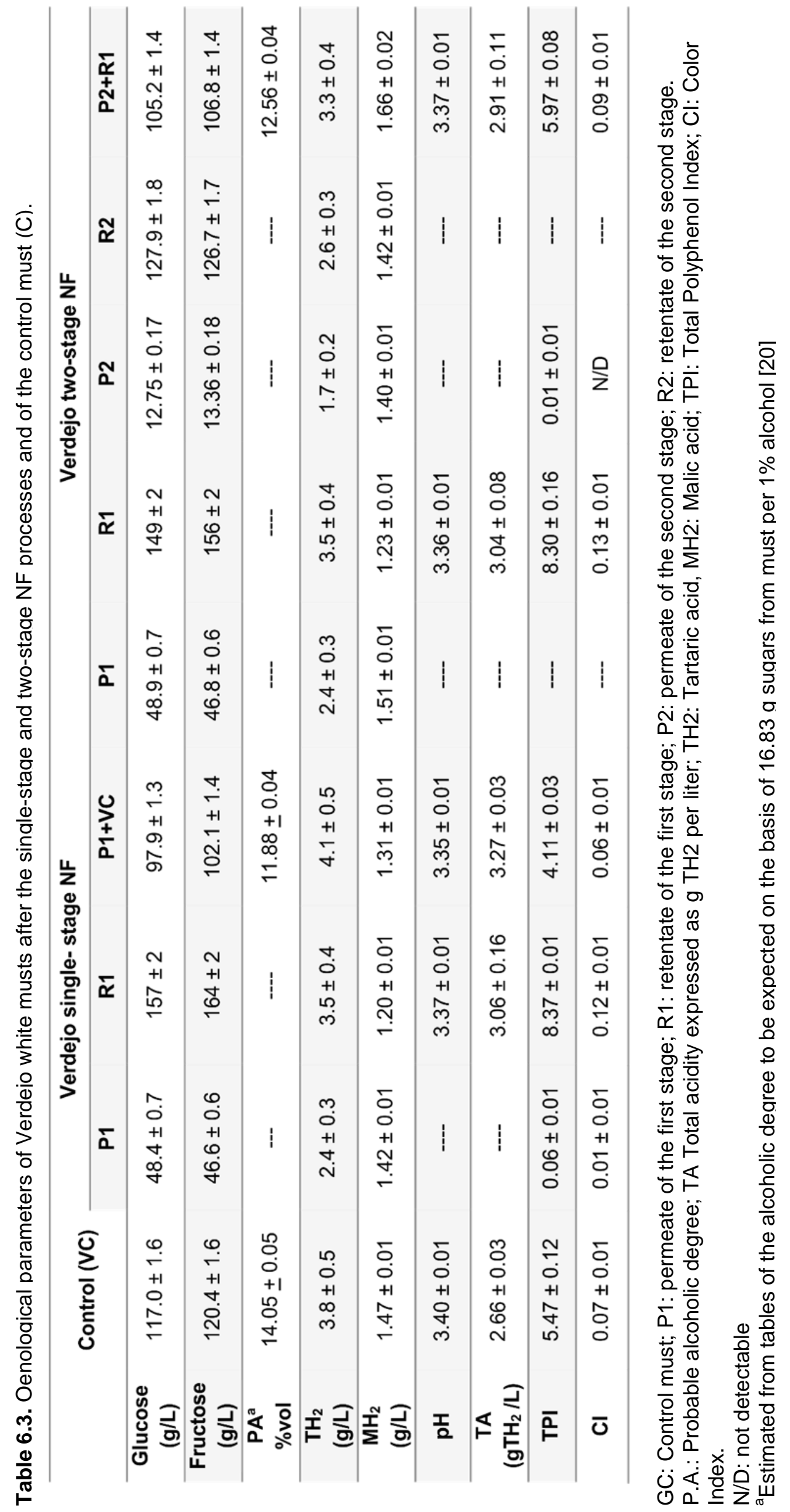


Results show that nanofiltration did not allow the passage of polyphenolic compounds due to their higher molecular weight. Therefore their concentration increased in the retentates and was lower in the permeate samples. Moreover, it can be seen that in the case of some permeate samples $\mathrm{Cl}$ could not be detected (N/D). The blending of the permeate with untreated must (single-stage NF) or with the retentate (two-stage NF) reduces the final loss of these compounds. Furthermore, as shown in Table 6.3, the mixture with the first retentate $(\mathrm{P} 2+\mathrm{R} 1)$ promotes a higher recovery of these substances than with untreated must. In this way, if the chemical and sensory characteristics of the wine obtained from the blend $(P 2+R 1)$ are similar or better than those of the blend $(\mathrm{P} 1+\mathrm{VC})$ it can be said that the best technique is the twostage NF. Besides, this process minimizes volume losses, as it will be discussed later.

\subsubsection{Production and analysis of wines}

As mentioned in section 6.3.4, six different wines were elaborated. Three Garnacha red wines: GC, G2NF1, G2NF2 and three Verdejo white wines: VC, V1NF and V2NF. Table 6.4 shows the results of the chemical analysis of the six wine samples.

In the case of the Garnacha wines, after the malolactic fermentation, wines G2NF1 and G2NF2 had an alcohol degree lower by $1.2^{\circ}$ and $1.4^{\circ} \%$ vol respectively in comparison to the control $\mathrm{C}$ wine. In both cases the alcohol reduction achieved was lower than the $2^{\circ}$ expected. This could be due to the additional input of untreated must (i.e. sugar content) remaining in the crushed grape mass that was blended with the mixture $(\mathrm{R} 1+\mathrm{P} 2)$ prior to the alcoholic fermentation. Regarding the parameters of Total Acidity (T.A.) and $\mathrm{pH}$, no significant differences were determined between the 2 nanofiltered samples and also in comparison with the control wine. Volatile acidity (V.A.) is similar for the G2NF1 and G2NF2 but slightly higher when compared to the control wine. This could be understood as a minor deterioration of must during the NF process, since the V.A. values correspond to the fatty acids including those related with the acetic series (i.e. acetic, acetate, formic, propionic, butyric). As also observed for the resulting musts, nanofiltration affected the concentration of polyphenols and the parameters related ( $\mathrm{Cl}$ and anthocyanins). Table 6.4 shows that wines G2NF1 and G2NF2 presented a $14 \%$ and $16.5 \%$ TPI loss respectively when compared with the control wine. 
Table 6.4.Chemical analysis for the main oenological parameters of the red and white wines

\begin{tabular}{|c|c|c|c|c|c|c|}
\hline \multirow{2}{*}{$\begin{array}{l}\text { Chemical } \\
\text { parameter }\end{array}$} & \multicolumn{3}{|c|}{ Garnacha } & \multicolumn{3}{|c|}{ Verdejo } \\
\hline & GC & G2NF1 & G2NF2 & VC & V1NF & V2NF \\
\hline \multirow{2}{*}{$\mathrm{pH}$} & $3.21 \pm$ & $3.29 \pm$ & $3.31 \pm$ & $3.37 \pm$ & $3.31 \pm$ & $3.42 \pm$ \\
\hline & 0.01 & 0.01 & 0.01 & 0.01 & 0.01 & 0.01 \\
\hline \multirow{2}{*}{$\begin{array}{c}\text { TA } \\
\left(\mathrm{gTH} \mathrm{TH}_{2} / \mathrm{L}\right)\end{array}$} & $4.60 \pm$ & $4.26 \pm$ & $4.05 \pm$ & $3.75 \pm$ & $3.92 \pm$ & $3.75 \pm$ \\
\hline & 0.03 & 0.03 & 0.05 & 0.05 & 0.03 & 0.05 \\
\hline \multirow{2}{*}{$\begin{array}{c}\text { VA } \\
(g / L)\end{array}$} & $0.23 \pm$ & $0.31 \pm$ & $0.34 \pm$ & $0.37 \pm$ & $0.18 \pm$ & $0.63 \pm$ \\
\hline & 0.01 & 0.01 & 0.01 & 0.01 & 0.01 & 0.05 \\
\hline \multirow{2}{*}{ TPI } & $42.9 \pm$ & $36.93 \pm$ & $35.85 \pm$ & $6.31 \pm$ & $5.37 \pm$ & $7.75 \pm$ \\
\hline & 0.4 & 0.04 & 0.07 & 0.08 & 0.01 & 0.05 \\
\hline $\begin{array}{c}\mathrm{AC} \\
(\mathrm{mg} / \mathrm{L})^{\mathrm{a}}\end{array}$ & $\begin{array}{c}371 \pm \\
14\end{array}$ & $355 \pm 2$ & $288 \pm 3$ & $4.4 \pm 1.9$ & $\begin{array}{c}2.63 \pm \\
0.01\end{array}$ & $2.2 \pm 1.9$ \\
\hline \multirow{2}{*}{$\mathrm{Cl}$} & $11.1 \pm$ & $8.19 \pm$ & $6.94 \pm$ & $0.09 \pm$ & $0.07 \pm$ & $0.10 \pm$ \\
\hline & 0.2 & 0.07 & 0.02 & 0.01 & 0.01 & 0.01 \\
\hline AD & $12.40 \pm$ & $11.20 \pm$ & $11.00 \pm$ & $13.88 \pm$ & $11.95 \pm$ & $14.00 \pm$ \\
\hline (\%vol) & 0.18 & 0.01 & 0.01 & 0.01 & 0.01 & 0.01 \\
\hline
\end{tabular}

G C: Garnacha Control wine, G2NF1and G2NF2: Red wines obtained from fermentation of the mixture (R1+P2), VC: Verdejo control wine, V1NF: white wine obtained after the fermentation of the mixture (VC+P1), V2NF: white wine obtained after the fermentation of the mixture $(\mathrm{R} 1+\mathrm{P} 2)$

TA: Total acidity expressed as $\mathrm{g} \mathrm{TH} 2$ per liter; $\mathrm{TH}_{2}=$ Tartaric acid; VA: Volatile acidity; TPI: Total Polyphenol Index; CI: Color Index; AC: Anthocyanins content; AD: Alcoholic degree ${ }^{a}$ Expressed as mg malvidin-3-glycoside per liter

Regarding the Verdejo samples, after alcoholic fermentation, V1NF wine had a $1.93^{\circ} \%$ vol lower alcohol content when compared to the control, but no alcohol degree reduction was achieved in the V2NF wine. Note that the sugar content of the must mixture (P2+R1) would have led to a lower alcohol degree. It is probable that some microbiological contamination could have promoted this. Also, the fermentation of this blend took longer than the one of the other musts causing the high VA and IC values measured for this sample. The degradation of the wine related to these parameters respectively is for example the formation of acetic acid and the oxidation of compounds related with the color of it.

Also a $15 \%$ TPI loss was determined for the V1NF sample.

All in all, it can be said that among the processes studied, the best NF technique is the two- stage process without backflush. This technique allows not only an appropriate sugar content reduction, but the mixture $(\mathrm{P} 2+\mathrm{R} 1)$ promotes a higher recovery of polyphenolic compounds (i.e. color). Besides it minimizes volume losses since the retentate of the first stage and the permeate of the second stage are used for the appropriate blend of must and. Only the permeate of the second stage and the 
volume retained in the pump and in the module are of no use. At a larger scale (industrial scale) these dead volumes are negligible and it is has been estimated that in the $2 \mathrm{NF}$ technique proposed the volume losses would be around $18 \%$.

\subsubsection{Chemical and sensory characteristics of the resulting wines}

Sensory evaluation of the wines was carried out only with 5 samples: 3 with lower alcohol content (G2NF1, G2NF2 and V1NF) and the respective control samples (GC and VC). The V2NF wine was not included in this analysis because fermentation was not correct. However, the process of sugar reduction was satisfactory, so the results of this experience have been kept.

Results of the chemical analysis (presented in Table 6.4) and acceptability test were put into a matrix form. This data matrix consisted of 5 wine samples (rows) by 12 variables (columns): 7 physicochemical and 5 sensorial.

The data matrix of variables analyzed was subjected to PCA in order to decrease the number of results associated with the data set while still explaining the maximum amount of variability present in the data [28]. In this way, a new set of orthogonal variables (PCs) was generated.

The first 2 PCs explain the $90.32 \%$ of the total variance in the data set. Figure 6.7 shows the plot of the 5 wine samples, the 5 sensorial and 7 physicochemical variables in the first 2 PCs. Furthermore, the first principal component, PC1, accounts for $69.92 \%$ of the variability data and PC2 explains the $20.41 \%$ of the data variance.

Specific patterns of correlations between the variables can be appreciated from the plot between the PCs, where the position of the variables respect to one other and their corresponding correlations can be visualized. In order to analyze this, the Pearson correlation between the sensorial and physicochemical variables tested was performed. Results showed that the chemical variables related with color, namely TPI, $\mathrm{Cl}$ and Anthocyanins are strong and positively correlated with the sensorial variable color $(r=0.945 ; r=0.972$ and $r=0.947$ respectively with a significance level $p<0.05$ ). Moreover, the sensorial variable flavor is positively correlated with $\mathrm{pH}(r=0.959$, $p<0.05)$ and negatively correlated with total acidity $(r=-0.994, p<0.05)$. Therefore it can be said, that these sensorial variables (evaluated by the consumers) are appropriately correlated with the chemical variables that describe them.

From the sensorial point of view it may be appreciated that none of the samples was particularly preferred by the consumers. Moreover, since there is no significant difference between the control or the filtered samples, this general trend can be attributed to an absence of substantial moddifications apart from the alcohol reduction. 
It can be noticed that red wines, especially the control (GC) and G2NF1, were preferred by their odor and color. The sample G2NF2 presented a high volatile acidity and lower TPI and therefore it is located further from the other two red wines and was less preferred. Since both, G2NF1 and G2NF2 were obtained from the same nanofiltrated must, it can be said that the differences of G2NF2 were caused by the fermentation and they are not related with the nanofiltration process. Results show that the filtration did not affect significantly the odour and color acceptance of the resulting red wines, since the G2NF1 had the highest color and odor acceptance. Regarding white wines, they showed the highest acceptance in flavor and overall liking, especially the control one. But they were not located in the space defined by the color and odor descriptors. Moreover, the sample V1NF presented lower persistence in mouth, flavor and overall liking. These features could be related, from the sensorial point of view, to a wine with a lower alcohol degree, even though the alcohol degree is not strongly correlated with any other descriptor. Besides, Verdejo is a variety characterized by its aroma components (volatile compounds). That is why nanofiltration could be more effective in the loss of these compounds in this variety.

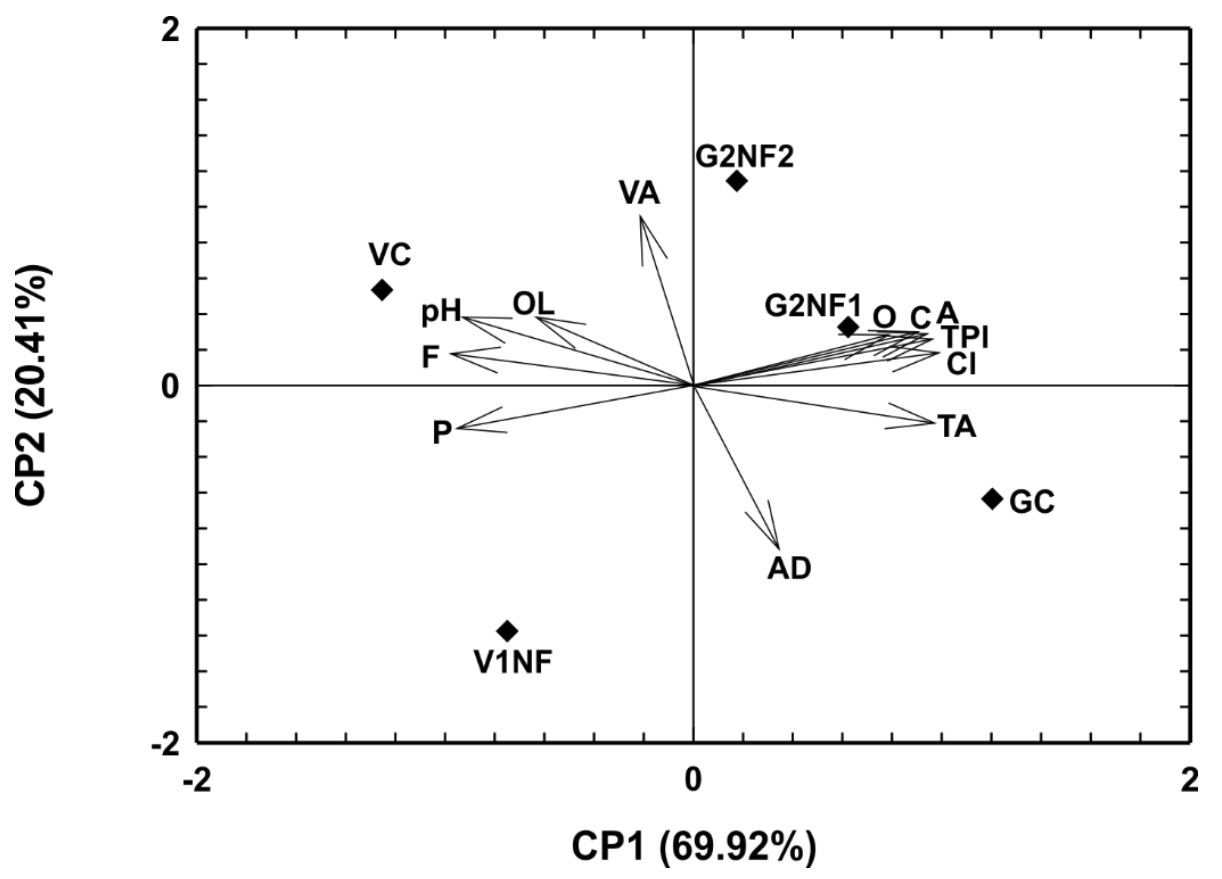

Figure 6.7. Principal Component Analysis of the wine samples and the physicochemical and sensorial characteristics. Symbols. Physicochemical variables: Anthocyanins (A); Total Acidity (TA); Volatile Acidity (VA); Total Polyphenol Index (TPI); Color Index (Cl); Alcoholic Degree $(A D)$. Sensory descriptors: Color (C); Odor (O); Flavor (F); Persistence (P); Overall liking (OL). Wine samples: Verdejo: Control (VC); single-stage (V1NF). Garnacha: Control (GC); two-stage (G2NF1) and fermentation duplicate (G2NF2). 


\subsection{Conclusion}

After the assessment of the different NF techniques studied, the main following conclusions can be raised:

- The use of backflush during the single-stage NF of Verdejo must is not appropriate since it caused lower permeate flow values. This means that it does not improve the productivity of the process.

- The mixture of the second must permeate with the first retentate (P2+R1) promoted a higher recovery of polyphenolic compounds than with untreated must $(\mathrm{P} 1+\mathrm{C})$.

Regarding the wines produced, the following conclusions can be made:

- The techniques studied here for sugar control in grape juice allow the partial reduction of alcohol in the resulting wine. Results show that the two-stage NF process promotes a higher IPT recovery and less volume losses.

- Sensory evaluation and PCA analysis showed that none of the wine samples was particularly preferred by the consumers, showing that there were no significant differences between the control and the filtered wines.

- NF did not affect significantly the odor and color of the resulting red wines, since the G2NF1 had the highest color and odor acceptance.

Moreover, the depletion of aroma components observed during Verdejo filtration may be analyzed in future studies by the recovery of these compounds using pervaporation before NF.

All in all, it can be said that this study reveals the feasibility of single-and-twostage NF processes for sugar reduction in grape must without a significant alteration of important compounds such as polyphenols, malic and tartaric acids. This allows the production of wines with sensorial and chemical characteristics similar as wines obtained of the fermentation of untreated musts. Therefore, this technique could be applied at a larger scale for the production of low alcohol content wines.

\subsection{Acknowledgments}

Authors would like to thank the "Ministerio de Ciencia e Innovación (MCINN)" for the financial support of this work within the frame of the "Plan Nacional de I+D+l" through the research projects, CTQ2012-31076 and MAT2011-25513. We also are grateful to the projects: VA-248U13 of the Junta de Castilla y León. 
C. Salgado wants to thank the Spanish Ministry of Education for the grant they gave to her within the frame of the "Plan Nacional de Investigación Científica, Desarrollo e Innovación Tecnológica 2008-2011" (FPU grant: AP2010-5769) to complete her PhD.

Authors also want to thank Miguel Angel García Esteban for his support during the fermentation procedures and wine analysis and the consumers that participated in the sensory tests. 


\subsection{Nomenclature}

Roman

$C_{0, i} \quad$ feed concentration of the i-th component $\left(\mathrm{kg} \mathrm{m}^{-3}\right)$

$C_{m, \mathrm{i}} \quad$ concentration of the $\mathrm{i}$-th component on the membrane active layer $\left(\mathrm{kg} \mathrm{m}^{-3}\right)$

$C_{p, i} \quad$ permeate concentration of the i-th component $\left(\mathrm{kg} \mathrm{m}^{-3}\right)$

$D_{i} \quad$ diffusion coefficient of the i-th component $\left(\mathrm{m}^{2} \mathrm{~s}^{-1}\right)$

$J_{v} \quad$ permeate flux per unit of area through the membrane $\left(\mathrm{m}^{3} \mathrm{~m}^{-2} \mathrm{~s}^{-1}\right)$

$J_{v}, 0 \quad$ permeate flux per unit of area through the membrane at time $t=0$ $\left(\mathrm{m}^{3} \mathrm{~m}^{-2} \mathrm{~s}^{-1}\right)$

$K_{m, i} \quad$ mass transfer coefficient $\left(\mathrm{m} \mathrm{s}^{-1}\right)$ of the i-th component at impermeable membranes $\left(\mathrm{m} \mathrm{s}^{-1}\right)$

$K_{m, i}^{s} \quad$ mass transfer coefficient of the $\mathrm{i}$-th component at semipermeable membranes $\left(\mathrm{m} \mathrm{s}^{-1}\right)$

$R_{f} \quad$ resistance due to fouling $\left(\mathrm{m}^{-1}\right)$

$R_{i} \quad$ membranes true retention for the i-th component

$R_{m} \quad$ membrane resistance $\left(\mathrm{m}^{-1}\right)$

\section{Greek}

$\Delta \pi \quad$ osmotic pressure gradient $(\mathrm{Pa})$

$\eta \quad$ solution viscosity (Pa s)

$\eta_{\mathrm{f}} \quad$ feed viscosity (Pa s)

$v_{\text {eff }} \quad$ effective velocity $\left(\mathrm{m} \mathrm{s}^{-1}\right)$

$\rho_{f} \quad$ feed density $\left(\mathrm{kg} \mathrm{m}^{-3}\right)$ 


\subsection{References}

[1] R. Mira de Orduña, Climate change associated effects on grape and wine quality and production, Food Research International, 43 (2010) 1844-1855.

[2] N. Garcia-Martin, S. Perez-Magarino, M. Ortega-Heras, C. Gonzalez-Huerta, M. Mihnea, M.L. Gonzalez-Sanjose, L. Palacio, P. Pradanos, A. Hernandez, Sugar reduction in white and red musts with nanofiltration membranes, Desalination and water treatment, 27 (2011) 167-174.

[3] A. Massot, M. Mietton-Peuchot, C. Peuchot, V. Milisic, Nanofiltration and reverse osmosis in winemaking, Desalination, 231 (2008) 283-289.

[4] J. Masson, P. Aurier, F. D'hauteville, Effects of non-sensory cues on perceived quality: the case of low-alcohol wine, International Journal of Wine Business Research, 20 (2008) 215-229.

[5] J. Labanda, S. Vichi, J. Llorens, E. López-Tamames, Membrane separation technology for the reduction of alcoholic degree of a white model wine, LWT - Food Science and Technology, 42 (2009) 1390-1395.

[6] OIV, International Code of Oenological Practices, OIV, Paris, 2012.

[7] N. García-Martín, L. Palacio, P. Prádanos, A. Hernández, M. Ortega-Heras, S. Pérez-Magariño, D.C. González-Huerta, Evaluation of several ultra- and nanofiltration membranes for sugar control in winemaking, Desalination, 245 (2009) 554-558.

[8] C. Salgado, F.J. Carmona, L. Palacio, P. Prádanos, A. Hernández, Evaluation of nanofiltration membranes for sugar reduction in red grape must, in: EUROMEMBRANE 2012, London, UK, 2012.

[9] C.M. Salgado, L. Palacio, P. Prádanos, A. Hernández, C. González-Huerta, S. Pérez-Magariño, Comparative study of red grape must nanofiltration: Laboratory and pilot plant scales Food and Bioproducts Processing, 94 (2015) 610-620.

[10] A.A. Kozinski, E.N. Lightfoot, Ultrafiltration of proteins in stagnation flow, AIChE Journal, 17 (1971) 81-85.

[11] R.L. Goldsmith, Macromolecular Ultrafiltration with Microporous Membranes, Industrial \& Engineering Chemistry Fundamentals, 10 (1971) 113-120.

[12] G. Jonsson, Boundary layer phenomena during ultrafiltration of dextran and whey protein solutions, Desalination, 51 (1984) 61-77.

[13] J.G. Wijmans, S. Nakao, C.A. Smolders, Flux limitation in ultrafiltration: Osmotic pressure model and gel layer model, Journal of Membrane Science, 20 (1984) 115124. 
[14] R.C. Kuhn, F. Maugeri Filho, V. Silva, L. Palacio, A. Hernández, P. Prádanos, Mass transfer and transport during purification of fructooligosaccharides by nanofiltration, Journal of Membrane Science, 365 (2010) 356-365.

[15] P. Prádanos, J.I. Arribas, A. Hernández, Retention of proteins in cross-flow UF through asymmetric inorganic membranes, AIChE Journal, 40 (1994) 1901-1910.

[16] C.P. Koutsou, S.G. Yiantsios, A.J. Karabelas, A numerical and experimental study of mass transfer in spacer-filled channels: Effects of spacer geometrical characteristics and Schmidt number, Journal of Membrane Science, 326 (2009) 234-251.

[17] G. Schock, A. Miquel, Mass transfer and pressure loss in spiral wound modules, Desalination, 64 (1987) 339-352.

[18] J. Schwinge, P.R. Neal, D.E. Wiley, D.F. Fletcher, A.G. Fane, Spiral wound modules and spacers: Review and analysis, Journal of Membrane Science, 242 (2004) 129-153.

[19] V. Geraldes, M.D. Afonso, Prediction of the concentration polarization in the nanofiltration/reverse osmosis of dilute multi-ionic solutions, Journal of Membrane Science, 300 (2007) 20-27.

[20] J. García - Barceló, Técnicas Analíticas Para Vinos, in, GAB, Barcelona, Spain, 1990.

[21] OIV, Compendium of International Methods of Wine and Must Analysis, OIV, Paris, 2011.

[22] A. Amerine, C.S. Ough, Análisis de vinos y mostos, 1st ed., Acribia Zaragoza. Spain, 1976.

[23] Ribereau-Gayon P., Stonestreet E., Le dosage des anthocyanes dans le vins rouge, Bulletin de la Société Chimique de France, 419 (1965) 2649-2652.

[24] C. Lasanta, I. Caro, J. Gómez, L. Pérez, The influence of ripeness grade on the composition of musts and wines from Vitis vinifera cv. Tempranillo grown in a warm climate, Food Research International, 64 (2014) 432-438.

[25] J.M. Rodriguez-Nogales, E. Fernández-Fernández, J. Vila-Crespo, Effect of the addition of $\beta$-glucanases and commercial yeast preparations on the chemical and sensorial characteristics of traditional sparkling wine, European Food Research and Technology, 235 (2012) 729-744.

[26] D.C. Sioutopoulos, S.G. Yiantsios, A.J. Karabelas, Relation between fouling characteristics of RO and UF membranes in experiments with colloidal organic and inorganic species, Journal of Membrane Science, 350 (2010) 62-82.

[27] C. Salgado, L. Palacio, F.J. Carmona, A. Hernández, P. Prádanos, Influence of low and high molecular weight compounds on the permeate flux decline in nanofiltration of red grape must, Desalination, 315 (2013) 124-134. 
[28] E.-C. Shin, B.D. Craft, R.B. Pegg, R.D. Phillips, R.R. Eitenmiller, Chemometric approach to fatty acid profiles in Runner-type peanut cultivars by principal component analysis (PCA), Food Chemistry, 119 (2010) 1262-1270.

[29] J.S. Vrouwenvelder, C. Picioreanu, J.C. Kruithof, M.C.M. van Loosdrecht, Biofouling in spiral wound membrane systems: Three-dimensional CFD model based evaluation of experimental data, Journal of Membrane Science, 346 (2010) 71-85. 


\subsection{Supplementary material}

The following are the supplementary data provided for this work.

Table S6.1 Main characteristics of the 3839 SR3-NYV spiral wound module

\begin{tabular}{|c|c|c|c|c|c|c|c|c|}
\hline $\begin{array}{l}\text { MWCO } \\
\left(^{\text {Da })^{a, b}}\right.\end{array}$ & $\begin{array}{l}\text { Lactose } \\
\text { Rejection } \\
(\%)^{\mathrm{a}, \mathrm{b}}\end{array}$ & $\begin{array}{c}\mathrm{pH} \\
\text { range }\end{array}$ & $\begin{array}{c}\text { Max. P } \\
\left(10^{5}\right. \\
P a)^{b}\end{array}$ & $\begin{array}{c}\text { Max. T } \\
\left({ }^{\circ} \mathrm{C}\right)^{b}\end{array}$ & $\begin{array}{c}\text { Active } \\
\text { membrane } \\
\text { Area } A_{m} \\
\left(\mathrm{~m}^{2}\right)^{\mathbf{b}}\end{array}$ & $\begin{array}{c}\text { Feed } \\
\text { spacer } \\
\text { porosity }^{c} \\
\varepsilon\end{array}$ & $\begin{array}{c}\text { Feed } \\
\text { spacer } \\
\text { height, } H \\
\left(10^{-3} \mathrm{~m}\right)^{\mathrm{b}}\end{array}$ & $\begin{array}{l}\text { Leaf } \\
\text { width } \\
W(m)^{d}\end{array}$ \\
\hline 200 & 99.900 & 3- 10 & 41.400 & 50.000 & 7.061 & 0.850 & 0.787 & 3.608 \\
\hline \multicolumn{9}{|c|}{${ }^{\mathrm{a}} 5 \%$ Lactose at $1380 \mathrm{kPa}$} \\
\hline \multicolumn{9}{|c|}{${ }^{\mathrm{b}}$ Provided by the manufacturer } \\
\hline \multicolumn{9}{|c|}{${ }^{c}[29]$} \\
\hline \multicolumn{9}{|c|}{ d Own determination } \\
\hline
\end{tabular}

Table S6.2 Hydraulic permeability, $L_{p}$, and membrane resistance, $R_{m}$, both initially and after filtration and cleaning procedure.

\begin{tabular}{|c|c|c|}
\hline Process & $\begin{array}{c}\text { Water } \\
\text { Permeability } L_{p} \\
\left(10^{-12} \mathrm{~m} / \mathrm{Pa} \cdot \mathrm{s}\right) \\
\end{array}$ & $\begin{array}{c}\text { Membrane Resistance } R_{m} \\
\left(10^{14} \mathrm{~m}^{-1}\right)\end{array}$ \\
\hline Initial: Before filtrations & 7.88 & 1.27 \\
\hline After red must two- stage NF & 6.15 & 1.62 \\
\hline $\begin{array}{c}\text { After white must single- } \\
\text { stage NF }\end{array}$ & 6.04 & 1.65 \\
\hline $\begin{array}{c}\text { After white must two- stage } \\
\text { NF }\end{array}$ & 5.78 & 1.72 \\
\hline $\begin{array}{l}\text { After manufacturers } \\
\text { cleaning procedure }\end{array}$ & 7.82 & 1.27 \\
\hline
\end{tabular}




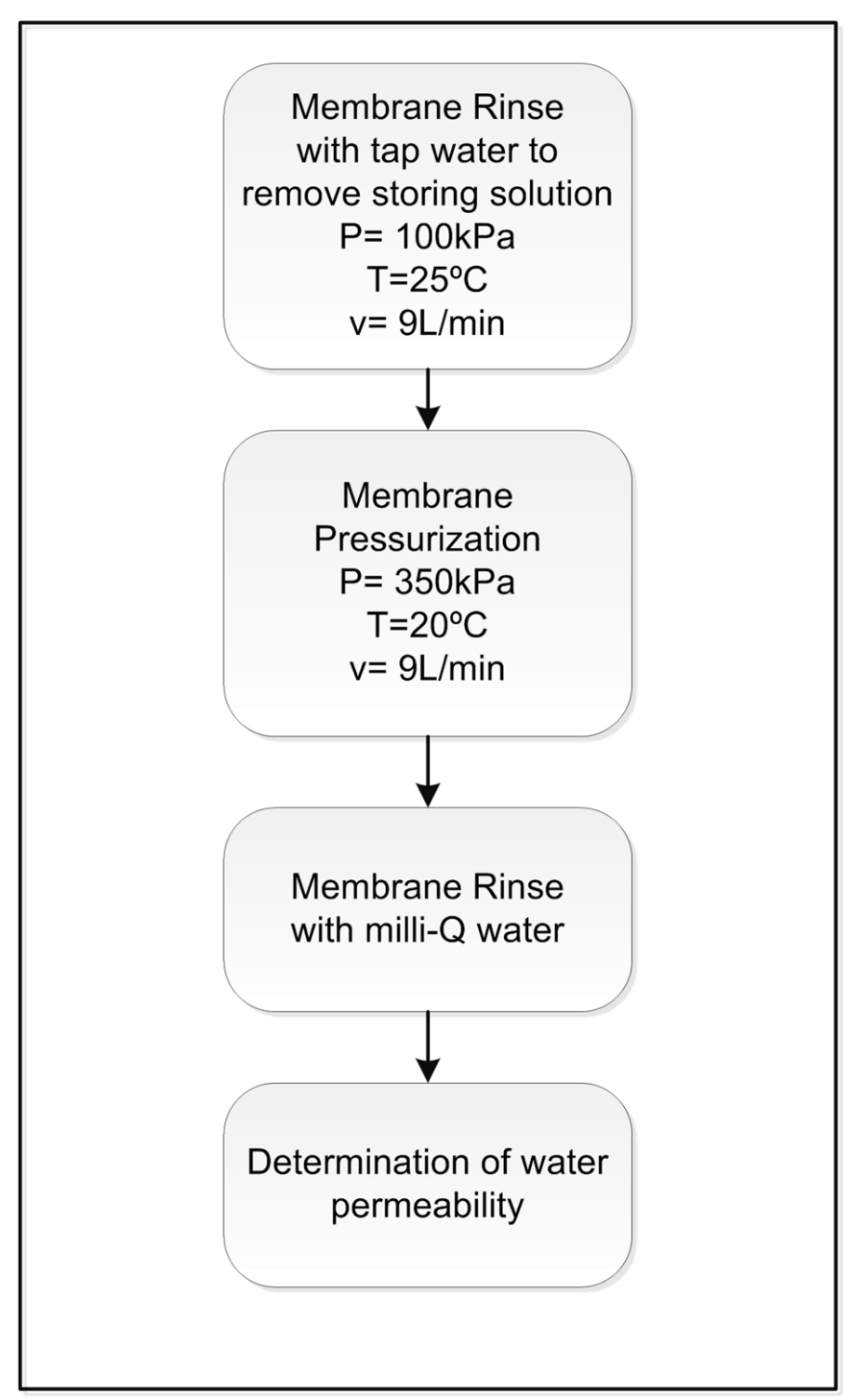

Figure S6.1. Procedure for Membrane conditioning 


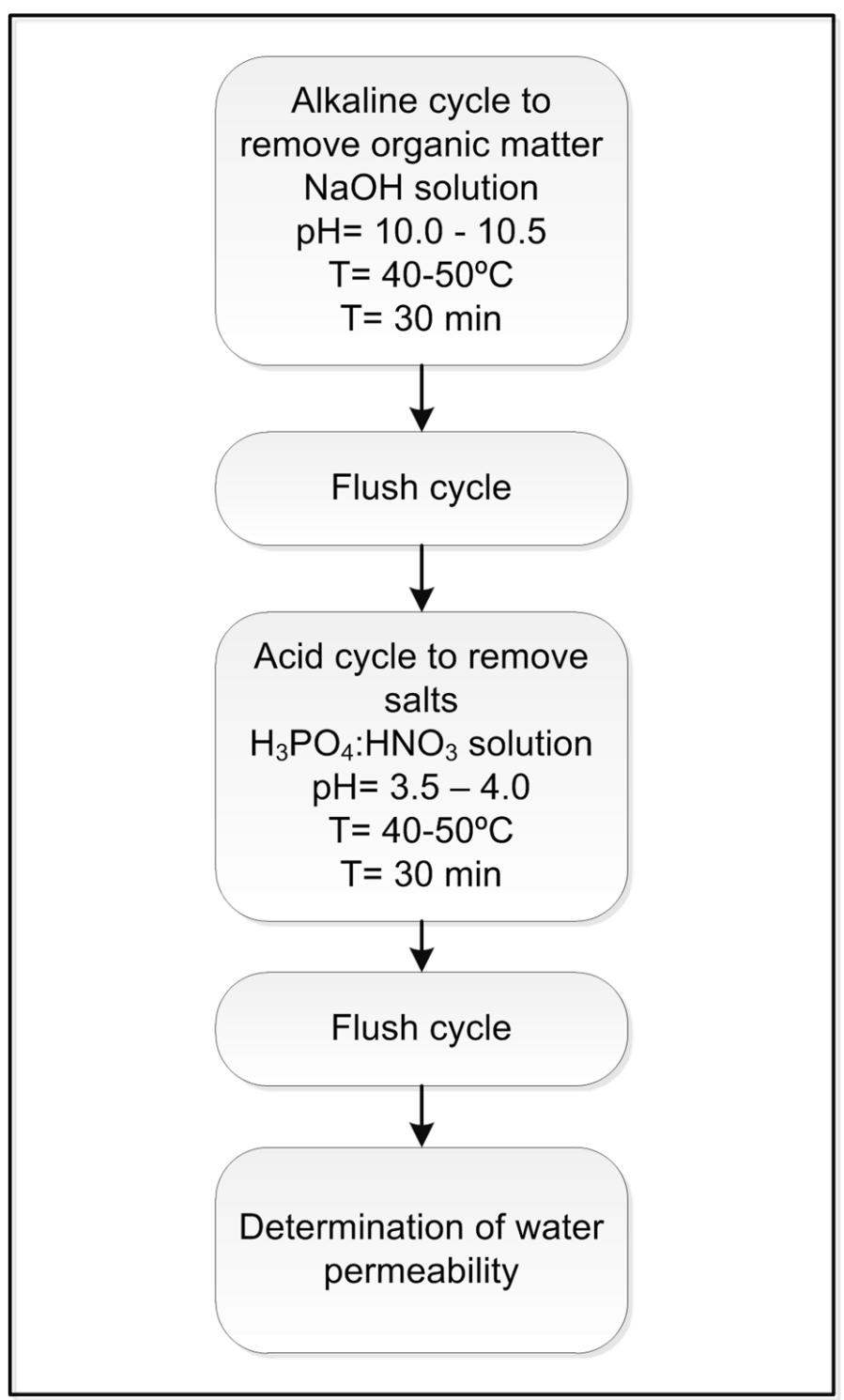

Figure S6.2 Cleaning Procedure for the SR3 Spiral Wound Module according to manufacturer's instructions 


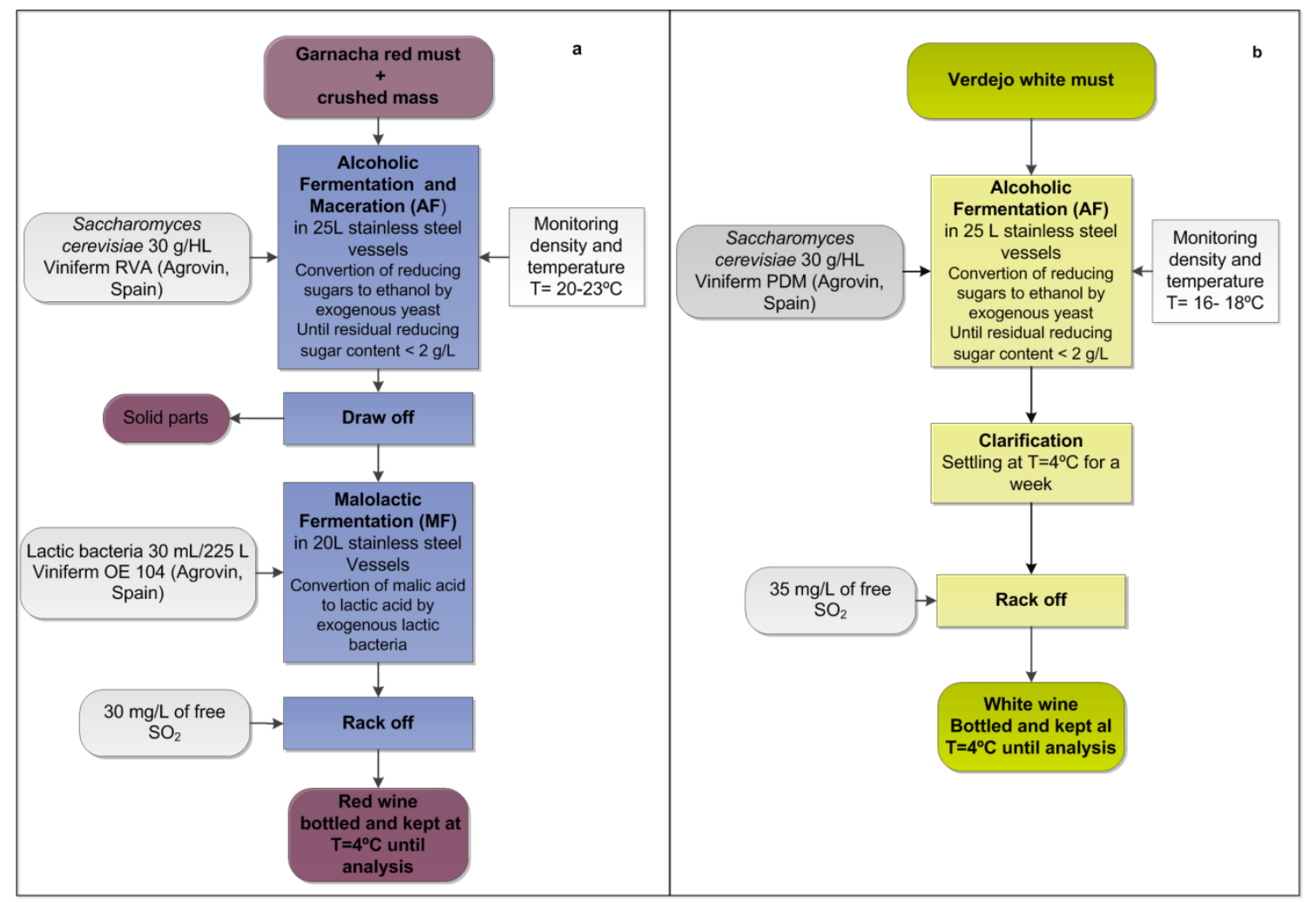

Figure S6.3 Traditional winemaking procedures for (a) red and (b) white wine 
SECTION IV. AROMA RECOVERY OF GRAPE MUST USING PERVAPORATION. ELABORATION OF A FULL FLAVORED LOW ALCOHOL CONTENT WINE 



\section{Chapter 7}

\section{Experimental investigation of pervaporation membranes for aroma recovery in white grape must}

Camila M.Salgado ${ }^{1}$, Laura Palacio ${ }^{1}$, Carla Brazinha², Antonio Hernández ${ }^{1}$, João G. Crespo ${ }^{2}$, Pedro Prádanos ${ }^{1}$

${ }^{1}$ Grupo de superficies y Materiales porosos (SMAP, UA-UVA-CSIC), Dpto. de Física Aplicada, Facultad de Ciencias, Universidad de Valladolid, 47011 Valladolid, Spain. ${ }^{2}$ REQUIMTE/CQFB, Department of Chemistry, FCT, Universidade Nova de Lisboa, 2829-516 Caparica, Portugal. 



\section{Chapter 7. Experimental investigation of pervaporation membranes for aroma recovery in white grape must}

\section{Abstract}

The aroma profile of natural beverages is typically formed by volatile organic compounds such as alcohols, aldehydes and esters usually present at low levels. In such conditions, pervaporation with organophilic membranes has a high potential for recovering natural aroma compounds.

The aim of this study is to assess the performance of pervaporation through membranes made of PEBA and PDMS for the recovery of primary aromas of grape juice. For this, pervaporation experiments were carried out using natural grape must and model solutions made of seven of the main aroma compounds present in it.

Results showed that during pervaporation of the model solution both membranes had higher selectivity for aldehydes than for alcohols. Even, the PEBA membrane was not able to permeate benzylalcohol. Moreover, higher selectivity for alcohols appeared through both membranes during pervaporation of natural grape juice, probably due to a higher interaction of aldehydes with the must liquid matrix. Finally, the analysis of the pervaporation performance revealed that the overall separation of the PDMS membrane is more efficient for aroma recovery of both feeds.

This research reveals that pervaporation is a powerful tool for the extraction of natural primary aroma for the grape juice and winemaking industries.

\section{Keywords}

Pervaporation, Organophilic membranes, Aroma recovery, Grape juice, Winemaking. 


\subsection{Introduction}

Aromas are of key relevance for foods and beverages since they are directly linked to the product quality and the consumer's acceptance [1]. A characteristic aroma profile is typically formed by a mixture of hundreds of different organic compounds usually present at ppm or ppb levels. They consist mainly in esters, alcohols, aldehydes, ketones, carboxylic acids, hydrocarbons, amines, mercaptans, terpenes, ethers, phenols, lactones, etc [2]. Among them, alcohols, aldehydes and esters, are in general extremely volatile. The loss of these compounds during beverage processing is often inevitable [3]. For example the concentration of beverages by evaporation would result in considerable losses and in some cases even total disappearance of all the volatile compounds in the evaporator. More recently, nanofiltration (NF) processes have been proposed in the wine industry to reduce the sugar content of grape juice and therefore to produce low alcohol content wines [4-6]. In their work, Garcia Martin et al. $[4,5]$ reduced by 2 degrees the alcohol content of wines fermenting grape musts by previously reducing their sugar content using NF membranes. The disadvantage of this process was that wines made from the nanofiltered musts showed a profile of volatile compounds that was poorer than that of the control wines. It seemed that during sugar reduction some of the primary aroma compounds or aroma precursors of wine were decreased.

Wine flavor and aroma profiles result from a combination of nonvolatile and volatile aromatic compounds. The first group is present in the grape juice and is responsible for the basic taste sensations (acidity, bitterness and astringency). The second group can be classified into primary, secondary and tertiary aroma compounds. The primary compounds, which correspond to the varietal characteristics, are present in the grapes and then in the wine; secondary aroma compounds are formed during fermentation and the tertiary aroma compounds are formed during maturation [7, 8]. The varietal aroma is mainly due to the volatile compounds which are whether in free volatile form or in bound form, usually as glycosides (having the aroma compound as aglycone) [8, 9]. The free form corresponds mainly to alcohols, aldehydes and esters, in a wide range of concentrations. As mentioned, these substances are extremely volatile.

In order to minimize the resulting impairment of the aroma and flavor quality of the final wine, the primary aroma compounds could be recovered from the grape juice before processing (by NF, for example) and then added back to the filtered must before fermentation. 
In view of their intrinsic characteristics, namely high selectivity and possibility of operation at moderate temperatures, pervaporation (PV) is a membrane process that seems highly appropriate for the separation of dilute species in liquid solutions. The possibility to operate $\mathrm{PV}$ at low temperatures is quite important when the aroma compounds of interest or the feed itself are susceptible of heat-induced deterioration. Moreover low temperatures imply less energy consumption [2, 3]. Specifically, organophilic PV membranes have a high potential for recovering natural and naturalidentical aroma compounds, highly diluted in complex aqueous media.

In this process a liquid feed mixture is separated by partial vaporization through a non-porous permselective membrane. Its separation mechanism is based on favorable molecular interactions between the dense membrane top-layer and the target compounds, allowing for their selective solubilisation in the membrane matrix and recovery in the permeate stream. The process results in a vapor permeate and a liquid retentate. The partial vaporization through the membrane is responsible for the separation potential of pervaporation. The driving force for the mass transfer of permeants from the feed side to the permeate one is a gradient in chemical potential, which is established by the application of a difference in the partial pressures of the permeants across the membrane. This difference in partial pressure can be created by partial pressure reduction on the permeate (downstream) side, which can be accomplished, for example, by applying vacuum or blowing a sweep inert gas on this side. Vacuum PV, is the most common way of performance, because it makes easy to reach low solute downstream partial pressures, assuring high driving forces for solute transport. The partial pressures of the permeant components are usually lower than their corresponding saturation pressures, and these components are therefore removed as vapor. The permeate is collected in cold traps, which at laboratory scale are normally cooled by using liquid nitrogen $(-196 \stackrel{\circ}{\circ})[2,3,10]$.

Aiming to recover organic compounds, the membrane naturally employed is organophilic. Elastomers normally present higher chain mobility than glassy polymers and contain non-polar side groups. Consequently, they preferentially permeate organic substances. Polydimethylsiloxane: PDMS is the most used material in the available literature studies on aroma recovery by pervaporation. A non-silicone membrane that is also available for this purpose consists in a thermoplastic polymer called polyetherblock-amide: PEBA. It is composed of rigid polyamide segments and flexible elastomeric polyether blocks [2]. The aim of the present work is to analyse the performance of the organophilic PV membranes made of PEBA and PDMS for the aroma recovery of primary aromas of grape juice. For this purpose, PV experiments will be carried out using a model solution made of the main aroma compounds present in 
grape must. Results will be then tested using natural grape must as feed of the experiments.

\subsection{Experimental}

\subsubsection{Materials}

\subsubsection{Model solution}

Grape must contains a great number of compounds making identification, quantification and analysis very complicated. Therefore, a model aqueous solution containing 6 of the most important aroma compounds of must, as found in the literature $[8,9,11]$, was used to simulate grape juice. These substances were two aldehydes: hexanal and benzaldehyde and four alcohols: isoamylalcohol, 1-hexanol, benzylalcohol and 2-phenylethanol. The concentration of each compound was $3.5 \pm 0.5 \mathrm{ppm}$.

The main physicochemical properties of water and the aroma substances are shown in Table 7.1. The data presented here for the molecular surface and Henry constant $\left(\mathrm{H}_{\mathrm{i}}\right)$ at $16{ }^{\circ} \mathrm{C}$ are necessary to calculate the theoretical selectivity that a PV membrane has for these compounds. This will be explained with more detail in section 7.2.5. These data were obtained using the Conductor-like Screening Model for Real Solvents (COSMO-RS) [12, 13] using the software COSMOthermX (COSMOlogic $\mathrm{GmbH}$, Leverkusen, Germany).

\subsubsection{Verdejo Grape Juice}

The grapes used for the experiments came from a Spanish white variety named Verdejo. They were cultivated in the experimental vineyard of the Institute of Agricultural Technology of Castilla y León (trial fields of Zamadueñas, Valladolid, Spain) from 2013 vintage. Verdejo grapes were destemmed, crushed, sulphited and pressed to obtain the respective must. Potassium metabisulphite was added $(80 \mathrm{mg} / \mathrm{L}$ of $\mathrm{SO}_{2}$ ) in order to prevent oxidation or spoilage caused by bacteria. Pectolytic enzymes (10 mg/L of Enozym Altair, Agrovin) were added to enhance first clarification.

The cleared must was filtered through $0.8 \mu \mathrm{m}$ cellulose filter plates in order to prevent ulterior membrane fouling. 
Table 7.1 Main properties of the aroma compounds present in the model solution

\begin{tabular}{|c|c|c|c|c|c|c|}
\hline Compound & Abbreviation & $\begin{array}{l}\text { Sensory } \\
\text { descriptor }\end{array}$ & $\begin{array}{l}\text { Molecular } \\
\text { Weight } \\
(\mathrm{g} / \mathrm{mol})\end{array}$ & $\begin{array}{c}\text { Boiling } \\
\text { Point } \\
(-\mathrm{C})(\text { at } \\
\text { 1atm) }\end{array}$ & $\begin{array}{c}\text { Molecular } \\
\text { Surface } \\
\AA^{2}\end{array}$ & $\underset{(\mathrm{kPa})}{\mathrm{H}_{\mathrm{i}}}$ \\
\hline Hexanal & HexAL & $\begin{array}{l}\text { Herbaceou } \\
\text { s, green, } \\
\text { crushed } \\
\text { grapes }\end{array}$ & 100.16 & 130 & 163.09 & 575.21 \\
\hline Isoamylalcohol & $i-A m O L$ & $\begin{array}{c}\text { Marzipan, } \\
\text { burnt, } \\
\text { alcoholic, } \\
\text { malty, } \\
\text { solvent }\end{array}$ & 88.08 & 132 & 144.98 & 18.169 \\
\hline 1-Hexanol & 1-HexOL & $\begin{array}{c}\text { Floral, } \\
\text { grass, } \\
\text { herbaceous } \\
\text { sweet }\end{array}$ & 102.16 & 158 & 169.50 & 35.301 \\
\hline Benzaldehyde & BezAL & $\begin{array}{c}\text { Dry, plastic, } \\
\text { bitter } \\
\text { almonds, } \\
\text { cherry } \\
\end{array}$ & 106.12 & 178.1 & 145.46 & 32.572 \\
\hline Benzylalcohol & $\mathrm{BezOL}$ & $\begin{array}{c}\text { Sweet, } \\
\text { fruity }\end{array}$ & 108.14 & 205 & 151.55 & 0.9427 \\
\hline $\begin{array}{c}2- \\
\text { Phenylethanol }\end{array}$ & 2-PhetOL & $\begin{array}{l}\text { Roses, } \\
\text { honey, dry } \\
\text { fruits }\end{array}$ & 122.16 & 219 & 170.78 & 0.9721 \\
\hline Water & $\mathrm{H}_{2} \mathrm{O}$ & & 18.015 & 100 & 43.10 & 1.7711 \\
\hline
\end{tabular}

After filtration, the content of total sugars (glucose and fructose), ${ }^{\circ} \mathrm{Brix}, \mathrm{pH}$, hexanal, isoamylalcohol, 1-hexanol, benzaldehyde, benzylalcohol and 2-phenylethanol were measured. Results are presented in Table 7.2.

Table 7.2 Original composition of Verdejo grape must

\begin{tabular}{|c|c|c|c|c|c|c|c|c|c|}
\hline & \multirow{2}{*}{$\begin{array}{c}\text { Glucose } \\
\text { +Fructos } \\
\text { e (g/L) }\end{array}$} & \multirow{2}{*}{ oBrix } & \multirow{2}{*}{$\mathrm{pH}$} & \multicolumn{6}{|c|}{ Aroma compound (ppb) } \\
\hline & & & & $\stackrel{x}{\stackrel{x}{x}}$ &. & 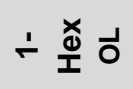 & $\stackrel{N}{\Phi}$ & 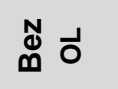 & ৯ $\frac{\bar{\Phi}}{a}$ \\
\hline $\begin{array}{l}\text { Verdejo } \\
\text { grape } \\
\text { must }\end{array}$ & $215 \pm 9$ & $\begin{array}{r}19.95 \\
\pm 0.07\end{array}$ & $\begin{array}{c}3.09 \pm \\
0.04\end{array}$ & $\begin{array}{c}8.06 \pm \\
0.73\end{array}$ & $\begin{array}{c}188 \pm \\
13\end{array}$ & $\begin{array}{c}1372 \pm \\
9\end{array}$ & $\begin{array}{c}23.5 \pm \\
1.8\end{array}$ & $\begin{array}{c}19 \pm \\
7\end{array}$ & $\begin{array}{c}68 \pm \\
6\end{array}$ \\
\hline
\end{tabular}

\subsubsection{Membranes tested}

Two different organophilic flat sheet membranes manufactured and commercialized by Pervatech (Pervatech BV, Rijssen, The Netherlands) were tested in this research. One of them was coated by the manufacturers with PDMS and the other with PEBA. 
The membrane morphology was investigated by scanning electron microscopy (SEM) using a Quanta 200 FEG (field emission gun) equipment of FEI (FEI Company Hillsboro, Oregon, USA). For this purpose, membranes were fractured with liquid nitrogen. Figures 7.1a and 7.1b show the cross section of the PDMS and PEBA membranes respectively. The upper dense layer, which is the selective part, can be seen. This active layer should be as thin as possible to minimize transport resistance. This layer is cast on a porous asymmetric support layer which shows the usual morphology of a membrane prepared by phase inversion. To further increase the mechanical stability of the membrane, this microporous support membrane is usually cast on a fabric fleece. As can be seen, the thickness of the PDMS active layer was smaller than that of the PEBA one. SEM images of transversal sections allowed determining the average thickness of both active layers. The PDMS selective layer thickness was $1.51 \pm 0.14 \mu \mathrm{m}$ while for PEBA it was equal to $2.07 \pm 0.15 \mu \mathrm{m}$.
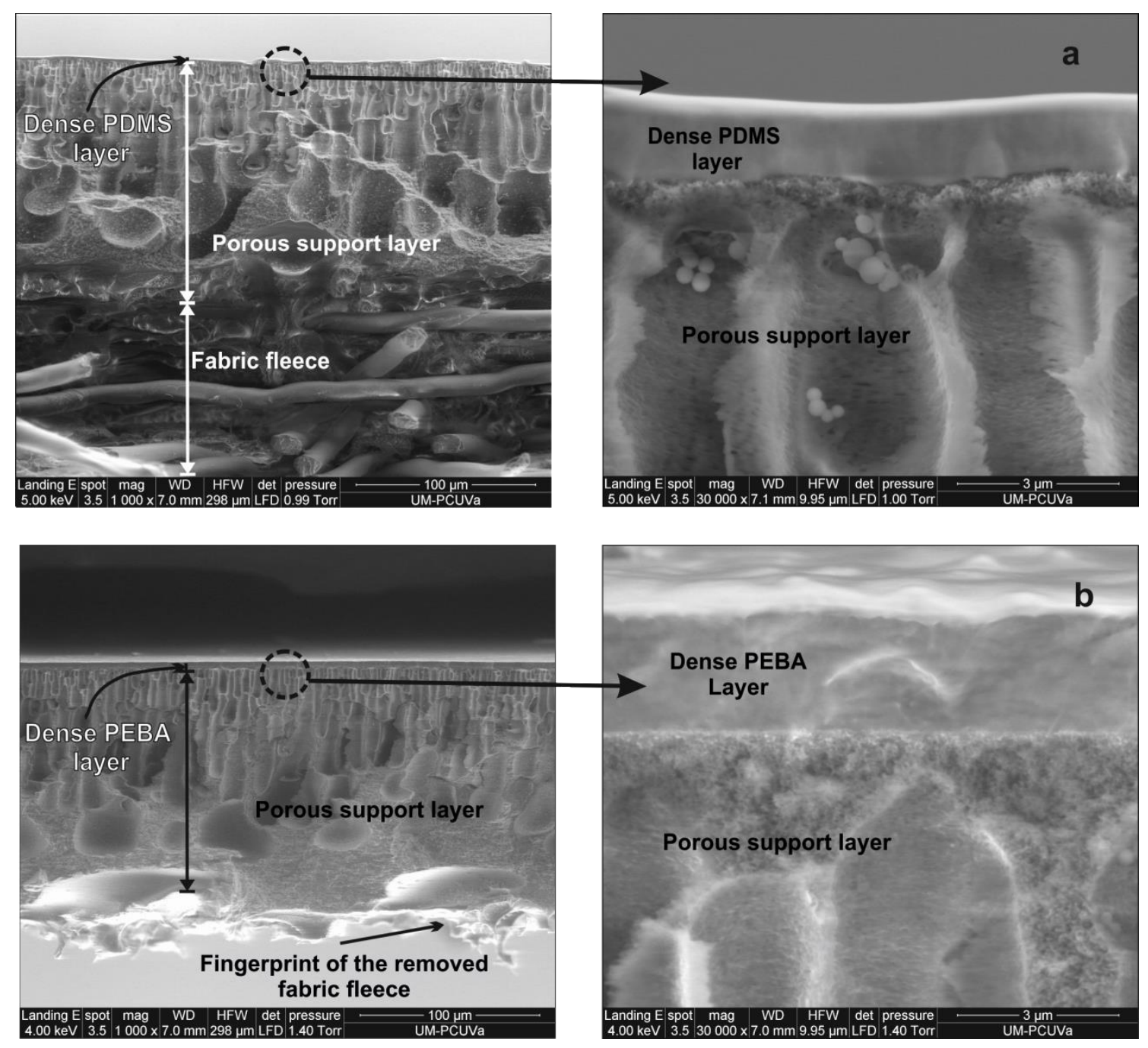

Figure 7.1 SEM images of the cross section of the membranes used here: PDMS (a) and PEBA (b) 


\subsubsection{Experimental Set-up}

An installation was designed and built for the test of the membranes for recovery of aroma compounds present in the model solution and grape must. It comprised a thermostated feed vessel; a pervaporation cell with the feed stream operated under controlled temperature and flow-rate and a downstream circuit with a condenser (Figure 7.2).

The module used was a stainless steel flat sheet crossflow module which is described in detail by Schäfer and Crespo [14]. According to it, the cell's dimensions provide a membrane active area $A_{m}=5 \cdot 10^{-4} \mathrm{~m}^{2}$ and a hydraulic diameter $d_{h}=2 \cdot 10^{-3} \mathrm{~m}$. The upstream tubing was in Viton and Teflon and the metal used in the permeate stream piping was made in stainless steel. The vacuum conditions in the downstream side were assured by a vacuum pump from Pfeiffer (Pfeiffer Vacuum Technology AG, Asslar, Germany). The unit was equipped with a pressure gauge on the permeate circuit consisting on a Capacitance Manometer, a transducer power supply and a monitor from Edwards (Atlas Copco, Nacka, Sweden), with readings of the permeate pressure, $p_{p e r m}$, independent from the nature of the gas or vapor present. The condenser was a glass $U$-shaped trap immersed in liquid nitrogen.

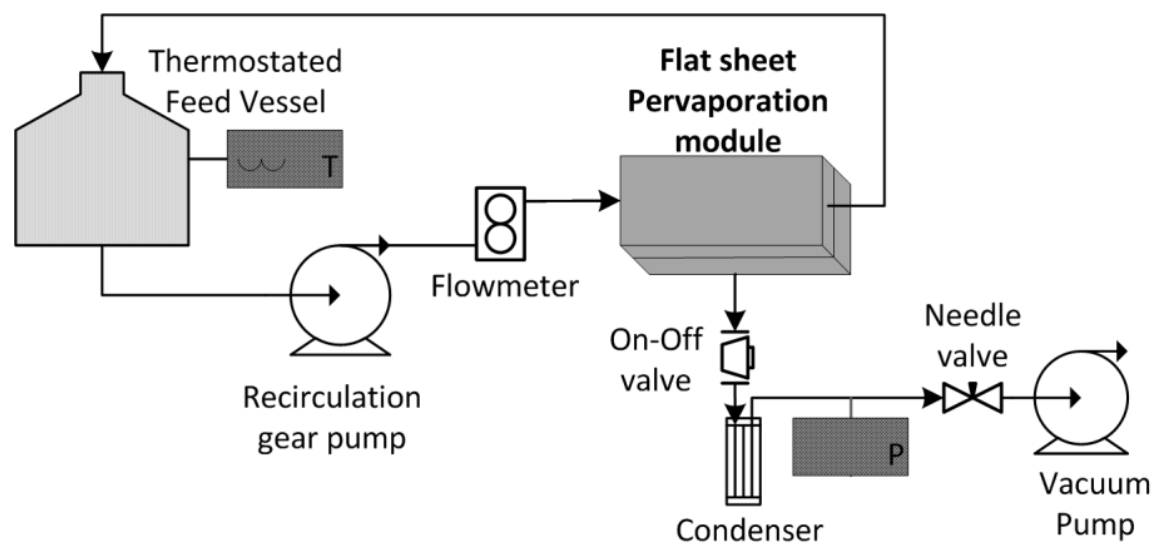

Figure 7.2 Scheme of the experimental set up

\subsubsection{Operating conditions}

In each set of experiments, with a defined feed solution, the following parameters were controlled: temperature of the feed stream, $T_{\text {feed }}=16 \pm 1{ }^{\circ} \mathrm{C}$, temperature of the condenser, $T_{\text {condens, }}$ which was kept constant at $-196{ }^{\circ} \mathrm{C}$ and the feed flow rate. The gear pump was set at the highest possible constant feed velocity. 
This gave two different limit feed tangential velocities, due to the different viscosity of the model solution and grape juice, namely about $5.96 \mathrm{~ms}^{-1}$ for the model solution and $4.93 \mathrm{~ms}^{-1}$ for the must. These corresponded to Reynolds numbers of $1.08 \cdot 10^{4}$ and $6.85 \cdot 10^{3}$ respectively. The downstream pressure was kept constant at $p_{\text {perm }}=1.5 \pm 0.5$ mbar.

In order to minimize the depletion of aromas during each experiment the feed vessel was kept closed and with a small headspace. The volume of the feed solution was $500 \mathrm{~mL}$ for the model solution and $250 \mathrm{~mL}$ for grape juice.

The duration of the experiments was $3 \mathrm{~h}$ when the model solution was used and $6 \mathrm{~h}$ when grape must was employed. In the first case, the duration of the experiment was shorter because the concentration of aromas was higher and condensation in the cold-trap tubing caused obstruction and vacuum was reduced. In the first case, the duration of the experiment was shorter since the concentration of aromas was higher and their condensation could cause obstruction of the cold traps.

Before each experiment the PV membrane was conditioned. Here, the PDMS and PEBA membranes were treated by filtering Milli-Q (Merck Millipore, Billerica, Massachusetts, USA) water under the same operating conditions. This is: $T_{\text {feed }}=16 \pm 1$ ${ }^{\circ} \mathrm{C}, p_{\text {perm }}=1.5 \pm 0.5 \mathrm{mbar}$ and $T_{\text {condens }}=-196{ }^{\circ} \mathrm{C}$. In this case, the experiment lasted for 2 h.

\subsubsection{Analytical Methods}

Samples coming from the experiments carried out using the model solution (i.e. feed, permeate and retentate) were analysed using an Agilent (Agilent Technologies) gas chromatograph equipped with a FID (flame ionization detector) and a split/splitless injector. Separations were conducted on a HP-INNOWax capillary column $(60 \mathrm{~m} \times 0.25$ $\mathrm{mm}$ i.d., and film thickness $0.5 \mu \mathrm{m}$ ) from Agilent Technologies. Helium was used as carrier gas at a constant linear velocity of $23.19 \mathrm{~cm} \mathrm{~s}^{-1}$. Injections $(1 \mu \mathrm{L})$ were done at $275 \mathrm{C}$ in the splitless mode. The oven temperature was held at $35^{\circ} \mathrm{C}$ for $1 \mathrm{~min}$. Then it was increased at a rate of $3{ }^{\circ} \mathrm{C} \min ^{-1}$ to $215^{\circ} \mathrm{C}$ (held for $5 \mathrm{~min}$ ) and then at $3^{\circ} \mathrm{C} \mathrm{min}^{-1}$ to $250^{\circ} \mathrm{C}$. The FID temperature was maintained at $250^{\circ} \mathrm{C}$. Hydrogen gas was used for FID at a flow rate of $30 \mathrm{~mL} \mathrm{~min}{ }^{-1}$. The flow rate of air for FID was $400 \mathrm{~mL} \mathrm{~min}{ }^{-1}$. The make-up gas (helium) flow rate was $45 \mathrm{~mL} \mathrm{~min}^{-1}$. The compounds were quantified by standard curves obtained of pure commercially available standards injected under the same conditions.

Due to the low concentration of compounds present in grape must, samples of the original juice, retentante and permeates had to be conditioned for their analysis. 
For this purpose a solid-phase microextraction (SPME) device from Supelco (SigmaAldrich Corporation) with a $10 \mathrm{~mm}$ fiber coated with $65 \mu \mathrm{m}$ PDMS/DVB was used. The grape extracts were analyzed by an Agilent Technologies Gas chromatography-mass spectrometry system (GC-MS). The gas chromatograph was equipped with a HPINNOWax capillary column $(60 \mathrm{~m} \times 0.25 \mathrm{~mm}$ i.d. $\times 0.5 \mu \mathrm{m})$ from Agilent and the carrier gas used was helium at a flow of $1.2 \mathrm{~mL} \mathrm{~min}^{-1}$. Prior to the first extraction, the fiber was conditioned in the GC injector port at $270^{\circ} \mathrm{C}$ for 30 min according to manufacturer's recommendations.

The major parameters that influence the SPME process had to be firstly optimized and the best conditions for the extraction of the volatile compounds were: 2 $\mathrm{mL}$ of the sample were transferred to a $4 \mathrm{~mL}$ vial; the ionic strength was adjusted with $0.8 \mathrm{~g} \mathrm{NaCl}$. The vial was sealed and the headspace extraction was performed for 60 $\min$ at $50 \stackrel{\circ}{\circ}$ keeping the sample under continuous stirring. After this the fiber was withdrawn into the needle, removed from the vial and inserted into the injector of the GC-MS system in splitless mode at $270{ }^{\circ} \mathrm{C}$ for $15 \mathrm{~min}$.

The GC oven temperature was programmed from $40{ }^{\circ} \mathrm{C}$ (held for $2 \mathrm{~min}$ ) to 215 $\stackrel{\circ}{ } \mathrm{C}$ at $3.1{ }^{\circ} \mathrm{C} \mathrm{min}^{-1}$ (held for $3 \mathrm{~min}$ ) and then to $250 \stackrel{\circ}{\circ}$ at $10 \stackrel{\circ}{\circ} \mathrm{min}^{-1}$. Agilent MSD ChemStation D.01.00 Build 75 (26-Aug-2003) software was used to acquire the GC/MS data. Compounds were identified by matching the mass spectra of the unknown peaks with the data stored in the Wiley Registry of Mass spectral Data, $7^{\text {th }}$ Edition (Agilent Part No.1730 A) library and were confirmed and quantified by standard curves obtained by the SPME of pure commercially available standards injected under the same conditions.

Standard curves were acquired using solutions in the appropriate concentrations of the standards hexanal $(98 \%)$, benzaldehyde $(\geq 99 \%)$, isoamylalcohol (98\%), 1-hexanol ( $\geq 99 \%)$, benzylalcohol (TraceCERT ${ }^{\circledR}$ ) and 2-phenylethanol $(\geq 99 \%)$. All substances were purchased from Sigma Aldrich, Spain.

\subsubsection{Methods of Calculation}

The performance of a PV process is often described by the following three parameters. The permeate flux, $J_{\mathrm{i}}$, which is the flow rate of permeate of the $\mathrm{i}$-th component per unit of membrane area expressed in $\mathrm{gh}^{-1} \mathrm{~m}^{-2}$. The mass concentration enrichment factor, $\beta_{\mathrm{i}}$, for the component $\mathrm{i}$ defined as the ratio of the mass concentration of $i$ in the permeate $C_{\mathrm{P}, \mathrm{i}}$ and the mass concentration of $\mathrm{i}$ in the feed, $C_{\mathrm{f}, \mathrm{i}}$ 


$$
\beta_{i}=\frac{C_{P, i}}{C_{F, i}}
$$

The ratio of enrichment factors of a compound $i$ and a compound $j$ indicates the selectivity or separation factor, $a_{i, j}$, that a membrane has for a compound $i$ in comparison with compound $\mathrm{j}$ :

$$
\alpha_{i, j}=\frac{\beta_{i}}{\beta_{j}}
$$

Usually, the permeation and selectivity of a membrane are inversely correlated; this is, when one factor increases, the other decreases. Therefore a composite parameter called pervaporation separation index (PSI) has been widely accepted to evaluate the overall performance of a membrane [15-17]. PSI is defined as:

$$
P S I=\left(\alpha_{i, j}-1\right) J_{i}
$$

According to del Olmo and coworkers [18] the selectivity of a membrane can be predicted and compared to the experimental one using

$$
\alpha_{i, j}=\frac{\Delta \delta_{j}^{2} A_{j} H_{i}}{\Delta \delta_{i}^{2} A_{i} H_{j}}
$$

where $A$ represents the molecular surface area (in $\AA^{2}$ ) and $\mathrm{H}$ (in $\mathrm{kPa}$ ) is the Henry constant of the component $\mathrm{i}$ or $\mathrm{j}$. The terms $\Delta \delta_{i}{ }^{2}$ and $\Delta \delta_{j}{ }^{2}$ give an idea of the distance between the component $\mathrm{i}$ or $\mathrm{j}$ and the polymer $\mathrm{p}$ in the space of the Hansen solubility parameters, calculated as:

$$
\Delta \delta^{2}=4\left(\delta_{i}^{d}-\delta_{p}^{d}\right)^{2}+\left(\delta_{i}^{p}-\delta_{p}^{p}\right)^{2}+\left(\delta_{i}^{h}-\delta_{p}^{h}\right)^{2}
$$

where $\delta^{d}$ is the Hansen dispersion parameter, $\delta^{p}$, the Hansen polarity parameter and $\delta^{h}$ the Hansen hydrogen-bonding parameter, of the component $\mathrm{i}$ or $\mathrm{j}$ and the membranes polymer p. As stated by Hansen [19, 20], the total energy of vaporization of a liquid can be divided in three individual parts: non-polar (atomic) dispersion forces, (molecular) permanent dipole-permanent dipole forces, and hydrogen bonding forces. 
The distance parameter describes all these cohesive forces which hold liquid molecules together and cause interactions between the membranes polymer and the feed solution molecules.

\subsection{Results and discussion}

\subsubsection{Model solution experiments}

Figure 7.3 shows the concentration results for the permeate and retentate obtained using the PEBA (a) and the PDMS (b) membranes in comparison to the feed of each experiment. As can be seen, both membranes have the same trend of permeation: aldehydes are more permeated than alcohols since the former ones are less polar. The less polar the aldehyde and/or alcohol is the higher its permeation. A very small amount of benzylalcohol (1.19 $\pm 0.01 \mathrm{ppm})$ was measured for the PDMS permeates and it was not detected in the case of PEBA ones.
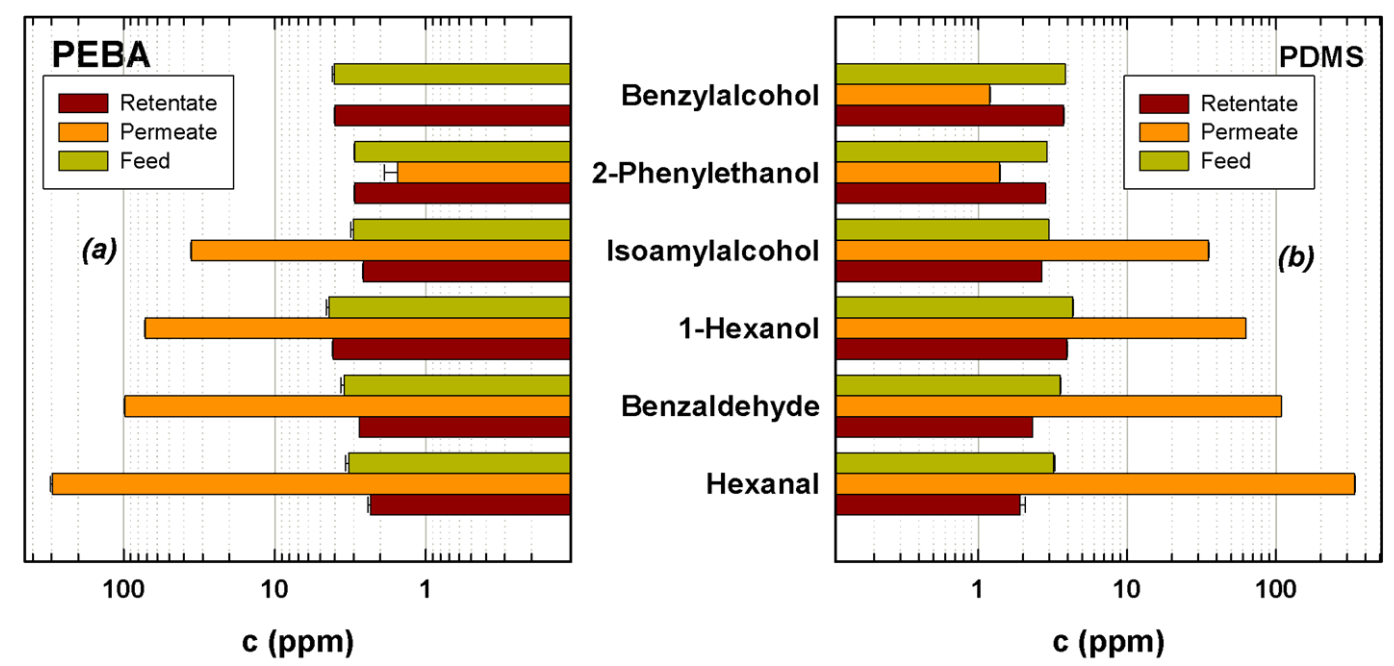

Figure 7.3 Concentration of aroma compounds in the permeate and retante for the synthetic solution, using the PEBA (a) and PDMS (b) membranes, in comparison to the feed.

After the conditioning procedures, the water flux of each membrane was measured and results showed (see Table 7.3) that PDMS has a higher hydraulic flux than PEBA. Actually this difference may be more related to the dissimilarity in the thickness of the dense layer of both membranes (see Figure 7.1), rather than to differences in the intrinsic permeability of both polymers. 
Table 7.3 Total and partial fluxes obtained of the Pervaporation of the aqueous model solution using PEBA and PDMS membranes. Also the water flux of the conditioning procedure of each membrane is presented here

\begin{tabular}{|c|c|c|c|c|c|c|c|c|c|}
\hline \multirow[b]{2}{*}{ Membrane } & \multirow[b]{2}{*}{$\begin{array}{c}\mathrm{J}_{\mathrm{H} 2 \mathrm{O}} \\
\text { conditioning } \\
\left(10^{3} \mathrm{~g} / \mathrm{hm}^{2}\right)\end{array}$} & \multirow[b]{2}{*}{$\begin{array}{c}J_{\text {total }} \\
\text { Model } \\
\text { solution } \\
\left(10^{3} \mathrm{~g} / \mathrm{hm}^{2}\right)\end{array}$} & \multicolumn{7}{|c|}{$\mathrm{J}_{\mathrm{i}}\left(\mathrm{g} / \mathrm{hm}^{2}\right)$} \\
\hline & & & 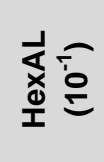 & 它 & 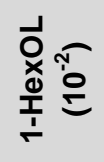 & 通产 & 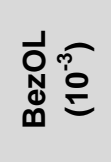 & 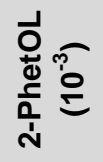 & 오ำ \\
\hline PEBA & 1.14 & 1.06 & 3.1 & 3.78 & 7.63 & 1.03 & ND & 1.63 & 1.06 \\
\hline PDMS & 1.38 & 1.22 & 4.12 & 4.30 & 7.66 & 1.33 & 1.46 & 1.70 & 1.22 \\
\hline
\end{tabular}

Based on the mass of model solution that permeated through the membrane area during the experimental time ( 3 hours) the overall flux $J_{\text {,tot }}$ was calculated. The PDMS membrane presented also a higher $J_{\text {tot, }}$ as can be appreciated in Table 7.3. Although when aroma compounds are present (as is the case of the model solution), PDMS membrane showed a $J_{t o t,} 15 \%$ higher than PEBA, although $20 \%$ higher $J_{t o t}$, was observed for pure water.

By using the permeate mass fraction of solvents in the permeate, the partial flux of each aroma compound $J_{i}$ was calculated (see Table 7.3). Higher partial fluxes were measured for the PDMS membrane for all the aroma compounds. As expected from the conditioning results, this membrane presented also a higher $J_{H 2 O}$. Moreover, both membranes showed partial fluxes of aromas 4 to 6 orders of magnitude smaller than the water flux. This is a consequence of the low concentration of these compounds in the feed. However, as seen in Figure 7.3 the increase of concentration of aromas in the permeate is significant.

To quantify the separation capacity of these membranes the enrichment factor $\left(\beta_{i}\right)$ and selectivity towards water $\left(\alpha_{i, H 2 O}\right)$ was calculated using Eqs. (1) and (2) for each solvent. The results obtained for these performance parameters are presented in Figure 7.4 versus one divided by the difference of the Hildebrand solubility parameter $(1 / \Delta \delta)$ of each component and of the polymer for both membranes. The Hansen solubility constants and $\Delta \delta$ are presented in Table 7.4. Regarding $\beta_{i}$ and $\alpha_{i, H 2 O}$ some observations can be made. Both parameters show an exponential growth with $(1 / \Delta \delta)$. This indicates that an increase of the solubility of the different solvents in the polymer leads to an increase of both the enrichment factor and the selectivity towards water, as expected [18]. Also, both membranes presented higher values for the aldehydes followed by alcohols without considerable differences in isoamylalcohol. Moreover, PEBA showed the best performance parameters for the alcohols 1-hexanol and 2phenylethanol but no benzyalcohol could be detected in the PEBA permeates. 
Table7.4 Hansen solubility parameters of PDMS [20], PEBA [21] and aroma compounds [19]

\begin{tabular}{cccccc}
\hline & \multicolumn{2}{c}{$\begin{array}{c}\text { Hansen solubility constants } \\
(\mathbf{M p a})^{\mathbf{1 / 2}}\end{array}$} & \multicolumn{2}{c}{$\begin{array}{c}\text { Distance parameter } \\
\text { Compound }\end{array}$} \\
\cline { 2 - 6 } & $\begin{array}{c}\delta^{\mathrm{D}} \\
\text { Dispersion }\end{array}$ & $\delta^{\mathrm{P}}$ Polar & $\begin{array}{c}\delta^{\mathrm{h}} \\
\text { Hydrogen } \\
\text { Bonding }\end{array}$ & $\left(\Delta \delta_{\text {PDMS }}\right)^{2}$ & $\left(\Delta \delta_{\text {PEBA }}\right)^{2}$ \\
\hline Hexanal & 15.8 & 8.5 & 5.4 & 15.73 & 71.09 \\
\hline Isoamylalcohol & 15.8 & 5.2 & 13.3 & 60.97 & 100.01 \\
\hline 1-Hexanol & 15.9 & 5.8 & 12.5 & 47.29 & 93.33 \\
\hline Benzaldehyde & 19.4 & 7.4 & 5.3 & 15.25 & 102.65 \\
\hline Benzylalcohol & 18.4 & 6.3 & 13.7 & 51.86 & 144.44 \\
\hline 2-Phenylethanol & 19.0 & 5.8 & 12.8 & 47.08 & 136.54 \\
\hline Water & 15.5 & 16.0 & 42.3 & 1348.00 & 1667.00 \\
\hline PDMS & 15.9 & 0.1 & 4.7 & & \\
\hline PEBA & 18.8 & 5.4 & 11.2 & & \\
\hline
\end{tabular}
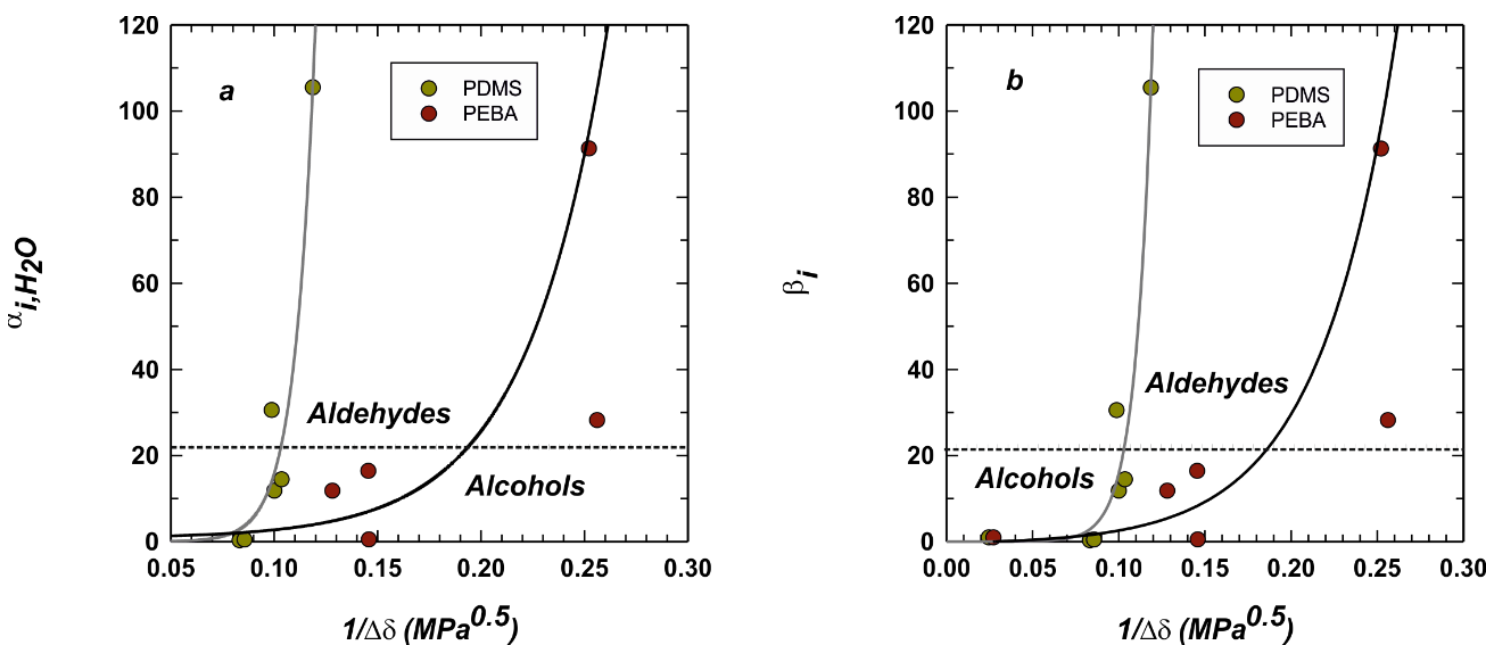

Figure 7.4 (a) Enrichment factor, $\beta_{i}$, of the $\mathrm{i}$-th aroma in the synthetic solution and (b) its selectivity towards water $\alpha_{i, H 2 O}$ versus the inverse the Hildebrand solubility parameter, $(1 / \Delta \delta)$.

In order to predict $\alpha_{i, H 2 O}$, the model proposed in Eq. (4) [18] was used. For this purpose the physicochemical data provided in Table 7.1 for each aroma compound and the Hansen solubility constants, presented in Table 7.4, were used. Figure 7.5a shows

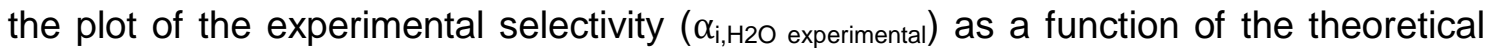

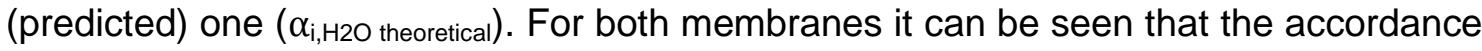
is far from being accurate as it should be if the points of the figure were on the plotted bisecting line. As also mentioned by del Olmo et al. [18], this difference can be explained because in Eq. (4) factors like the interaction solute-solute (mutual influence) or flux coupling are not taken into account. 
Figure $7.5 \mathrm{~b}$ shows the difference $\left(\alpha_{\mathrm{i}, \mathrm{H} 2 \mathrm{O}}\right.$ theoretical $-\alpha_{\mathrm{i}, \mathrm{H} 2 \mathrm{O}}$ experimental $)$ for each membrane. As can be seen, PDMS data have smaller differences than PEBA. This means that the selectivity of the PDMS membrane can be better predicted by this model for all aroma compounds present in grape juice. Higher $\alpha_{i, H 2 O}$ and flow and similar or higher values of enrichment for the PDMS membrane mean that this membrane has an overall higher performance, in separating aromas from water, than PEBA.
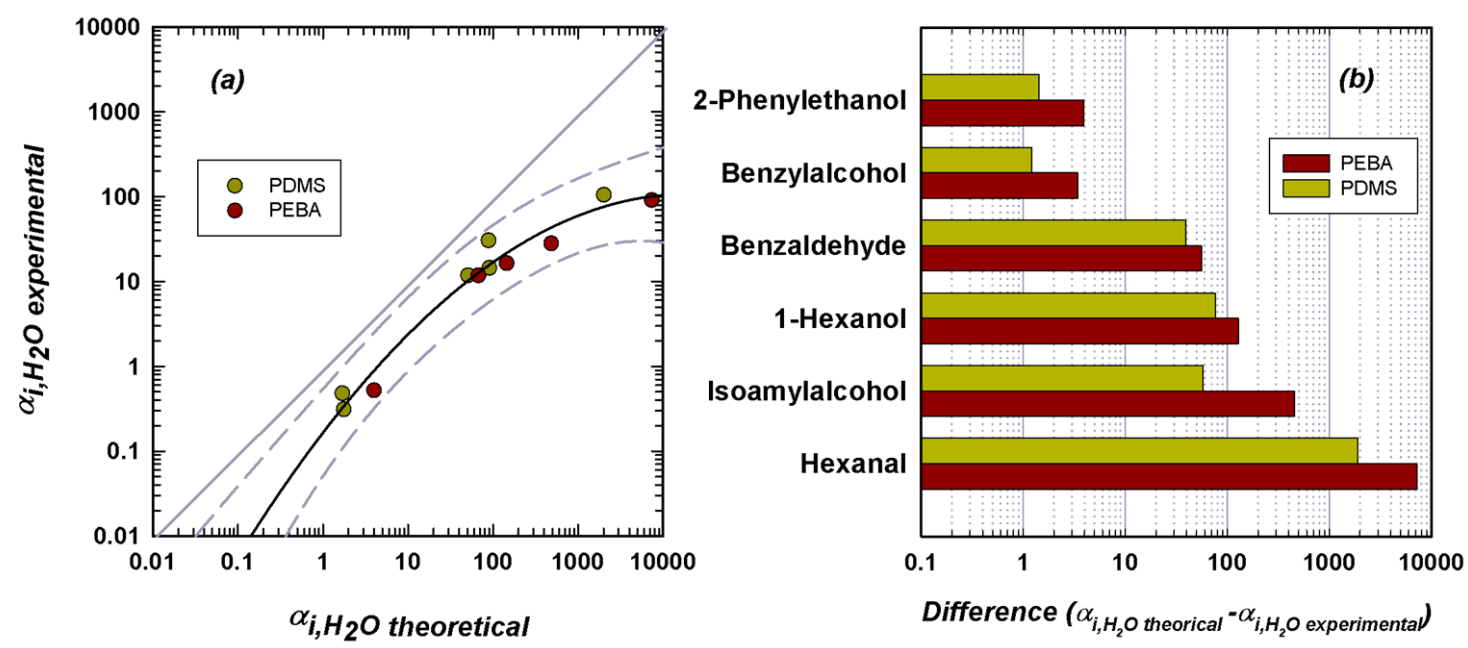

Figure 7.5 For both membranes: (a) Experimental selectivity to water in the synthetic solution (Eq. (2)) versus. the theorical one (Eq. (3)) and (b) difference $\left(\alpha_{i, H 2 O}\right.$ theorical $-\alpha_{i, H 2 O}$ experimental $)$

\subsubsection{Pervaporation of grape must}

Results obtained from the PV experiments using grape must are presented in Table 7.5. Higher $J_{\text {tot }}$ values were measured for the PDMS membrane similarly to the case of the model solution. Also PDMS shows the highest partial fluxes for all compounds except for 1-hexanol and hexanal.

Table 7.5 Total and partial fluxes obtained of the Pervaporation of grape must using PEBA and PDMS membranes.

\begin{tabular}{|c|c|c|c|c|c|c|c|c|}
\hline \multirow[b]{2}{*}{ Membrane } & \multirow[b]{2}{*}{$\begin{array}{c}J_{\text {total }} \\
\text { Grape } \\
\text { must } \\
\left(10^{2} \mathrm{~g} / \mathrm{hm}^{2}\right)\end{array}$} & \multicolumn{7}{|c|}{$J_{i}\left(g / h^{2}\right)$} \\
\hline & & 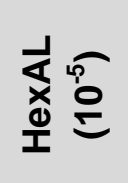 & 울 & 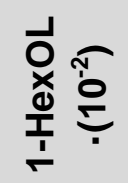 & 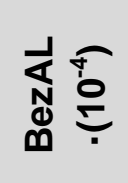 & 융 & 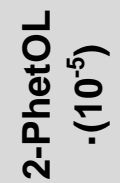 & 웅 \\
\hline PEBA & 9.41 & 12.07 & 3.13 & 3.76 & 2.92 & 7.13 & 9.97 & 9.41 \\
\hline PDMS & 9.87 & 6.94 & 3.65 & 3.08 & 4.13 & 33.56 & 99.71 & 9.87 \\
\hline
\end{tabular}


Once again, using Eq. (1) the enrichment factor of each compound was calculated for both membranes. The selectivity of each aroma towards the compounds present in grape juice except the aromas studied $\alpha_{i, m u s t}$ was calculated. Results of both parameters obtained for the experiments with grape must are compared with those obtained using the model solution as feed in Figure 7.6.
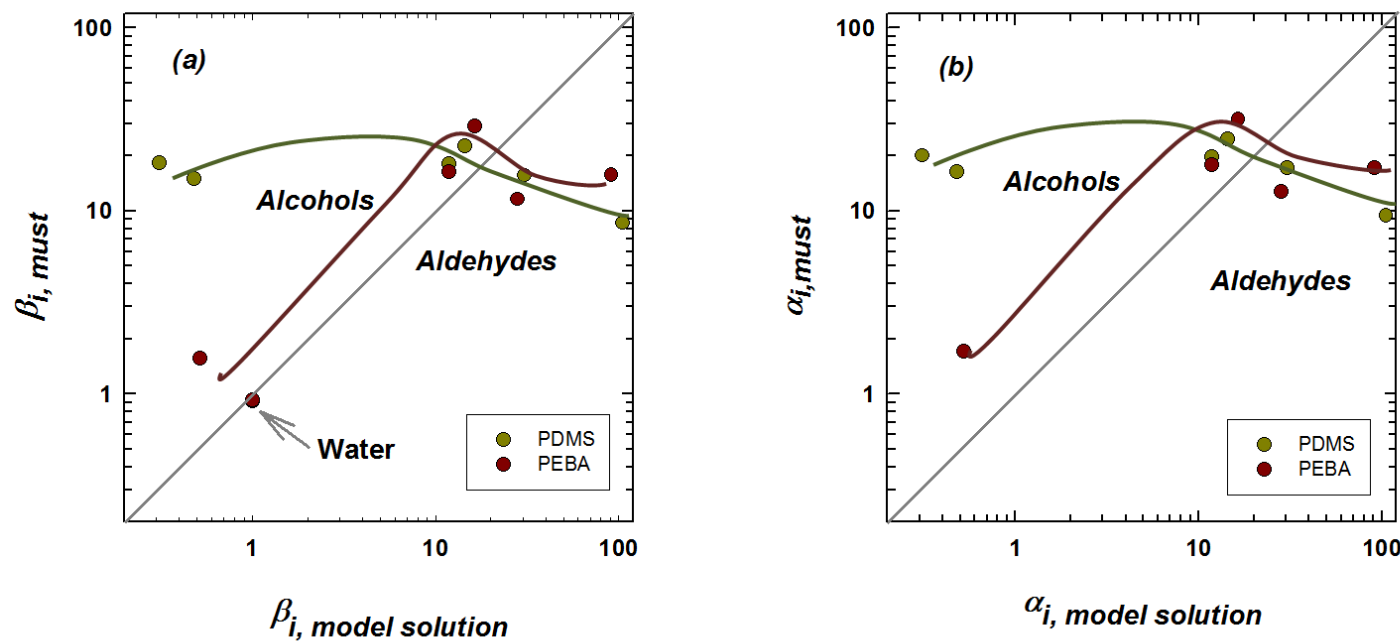

Figure 7.6 Comparison of the enrichment factor, $\beta_{\mathrm{i}}$, (a) and selectivity towards water, $\alpha_{\mathrm{i}, \mathrm{H} 2 \mathrm{O}}$, (b) of grape must vs. model solution for both membranes PEBA and PDMS. The lines are simply for orientation purposes

According to the results shown in Tables 7.3 and 7.5 and Figures 7.4 and 7.6, some particular differences can be observed:

- In the presence of grape juice, the trend of passage of the compounds through the membrane changes, especially for the PDMS. Now it is higher for alcohols than for aldehydes.

- It should be noticed that the values of $\alpha_{i, m u s t}$ (and also for $\beta_{i}$ ) are lower than those for the synthetic solution for aldehydes and higher for alcohols.

- For the must, PDMS shows the highest partial fluxes (and therefore greater enrichments) for all compounds except for 1-hexanol and hexanal. In the case of the synthetic solution these exceptions do not appear.

- Both membranes allow a high passage of benzylalcohol in comparison to the other aromas.

Results show that both membranes exhibit, in general, the same differences in their separation behavior when comparing their performances during the PV of the model solution and grape must. These can be attributed to several factors. One of 
them is the different environment of the feeds studied. It seems that in the case of grape must aldehydes have a stronger interaction with the liquid matrix than in the model solution. That is why in the former, aldehydes showed lower selectivities than expected, contrary to alcohols. Another factor can be the different ratios of aroma compounds in both feeds. While the model solution had approximately the same content of each aroma compound (3.5 ppm), in grape juice different ratios, with much lower concentrations, were measured for them (see Table 7.2). Of course, solutes can show quite different permeation behavior when their concentrations or ratios in the feed change. This mutual influence was observed by Heitmann and coworkers [21] when they studied the performance of PDMS and PEBA membranes for the recovery of acetone, butanol and ethanol compounds from feeds which contained different ratios of solutes.

To evaluate the separation efficiency of the different investigated membranes, pervaporation separation index (PSI) (Eq. (3) was calculated. Figure 7.7 shows the corresponding PSI of the pervaporation of both, model solution and grape juice using the PDMS membrane versus the one using the PEBA membrane.

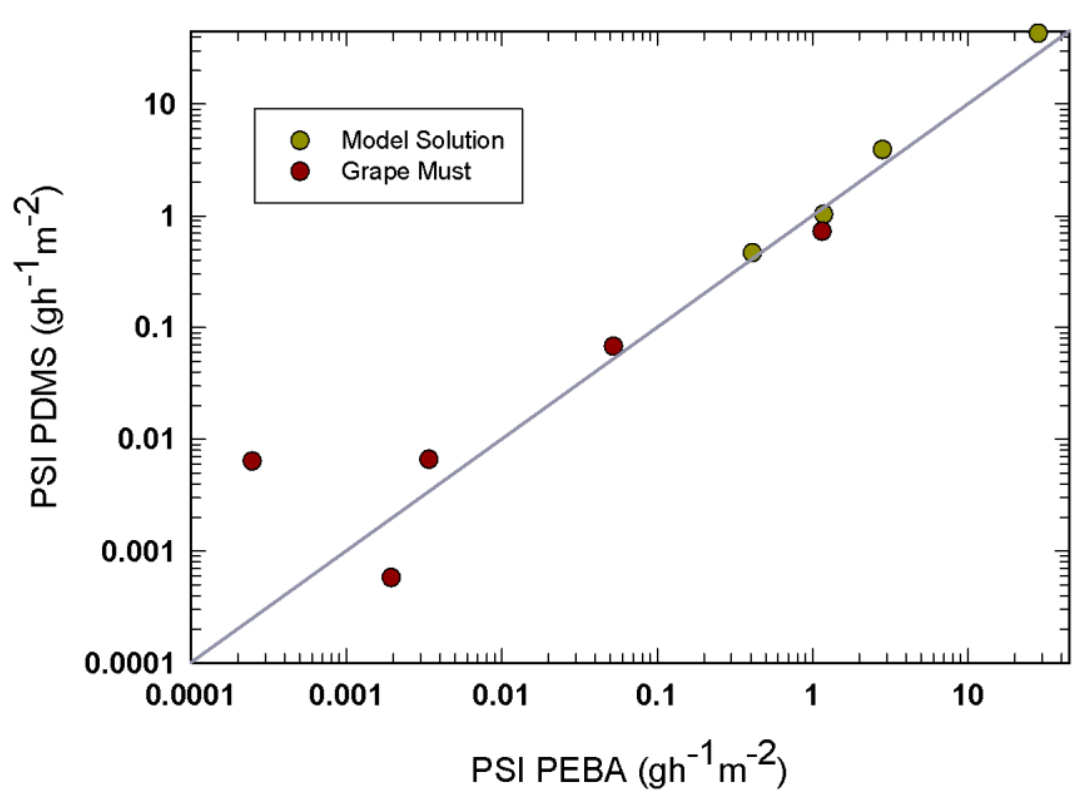

Figure 7.7 Pervaporation separation index (PSI) of the PDMS membrane versus PEBA membrane for both, model solution (green circles) and grape juice (red circles).

As can be appreciated, for model solution and grape juice, more PSI values are located over the bisecting line plotted. This means that PDMS membrane presents higher PSI for more aroma compounds than the PEBA membrane. The pervaporation separation of the PEBA membrane was higher only for 2 of the 7 aroma compounds 
studied here. Specifically, in the pervaporation of the model solution and grape juice, 1hexanol exhibited a more efficiently separation using the PEBA membrane. Also hexanal was better recovered from grape juice using this membrane but not from the model solution.

Results obtained for the PDMS and PEBA membranes tested within this research show that both membranes could be appropriate for aroma recovery in grape juice since the performance differences between them are scarce. But it seems that the use of a PDMS membrane could be better suited for our aim. First of all, this membrane showed higher $J_{\text {tot }}$ for both feeds, model solution and grape juice. Despite both membranes presented different permeation behaviors during the pervaporation of the model solution and grape juice, the PDMS membrane showed an appropriate selectivity to all compounds of interest and for both feeds. Moreover, the analysis of PSI showed that the recovery of more aroma compounds of the model solution and grape juice is more efficient using the PDMS membrane.

This means that the results obtained here show signs of future success in the use of PDMS membranes for aroma recovery in the wine industry and, in general, in beverage production.

\subsection{Conclusions}

During model solution experiments it was observed that both membranes have higher selectivity for aldehydes than for alcohols. But PEBA membrane is not selective to benzylalcohol since this compound could not be detected in its permeate. In general, PDMS membrane presented better permeation performance parameters.

Both membranes showed a different permeation behavior during pervaporation of grape juice tests changing to a higher selectivity for alcohols. This means that probably aldehydes have stronger interactions than alcohols with the rest of the components of grape must.

This study reveals the feasibility of pervaporation for natural aroma recovery in beverages to decrease aromatic depletion before their processing. Even though both membranes exhibited similar performance, PDMS showed the best permeation behavior to all compounds of interest and for both feeds.

\subsection{Acknowledgments}

Spanish authors would like to thank the "Ministerio de Ciencia e Innovación (MCINN)" for the financial support of this work within the frame of the "Plan Nacional de 
I+D+l" through the research projects, CTQ2012-31076 and MAT2011-25513. We also are grateful to the projects: VA-248U13 of the Junta de Castilla y León.

C. Salgado wants to thank the Spanish Ministry of Education for the grant they gave her: FPU grant: AP2010-5769 to complete her PhD.

Spanish authors thank also Sofia Fraga (REQUIMTE/CQFB, FCT, Universidade Nova de Lisboa, Caparica, Portugal) for her support during the PV experiments. 


\subsection{Nomenclature}

\section{Roman}

A

$A_{m}$

$\mathrm{C}_{\mathrm{F}, \mathrm{j}}$

$\mathrm{C}_{\mathrm{P}, \mathrm{j}}$

$d_{h}$

$\mathrm{H}_{\mathrm{i}}$

$\mathrm{J}_{\mathrm{i}}$

PSI

Greek

$a_{i, j}$

$\beta_{\mathrm{i}}$

$\Delta \delta^{2}$

$\Delta \delta^{\mathrm{d}}$

$\Delta \delta^{\mathrm{h}}$

$\Delta \delta^{p}$
Surface area $\left(\AA^{2}\right)$

Membrane active area $\left(\mathrm{m}^{2}\right)$

Mass concentration of the i-th compound in the feed $\left(\mathrm{kgm}^{-3}\right)$

Mass concentration of the i-th compound in the permeate $\left(\mathrm{kgm}^{-3}\right)$

Hydraulic diameter $(\mathrm{m})$

Henry constant of the $(\mathrm{kPa})$

Permeate flux of the i-th compound $\left(\mathrm{gh}^{-1} \mathrm{~m}^{2}\right)$

Pervaporation separation index $\left(\mathrm{gh}^{-1} \mathrm{~m}^{-2}\right)$

Selectivity for the i-th compound towards the $\mathrm{j}$-th compound.

(dimensionless). With $\mathrm{j}=\mathrm{H}_{2} \mathrm{O}$ for the model solution and $\mathrm{j}=$ must in grape must

Mass concentration enrichment factor (dimensionless)

Distance between the $\mathrm{i}$-th or $\mathrm{j}$-th component to the polymer $\mathrm{p}(\mathrm{MPa})$

Hansen dispersion parameter $\left(\mathrm{MPa}^{0,5}\right)$

Hansen hydrogen-bonding parameter $\left(\mathrm{MPa}^{0,5}\right)$

Hansen polarity parameter $\left(\mathrm{MPa}^{0,5}\right)$ 


\subsection{References}

[1] F. Lipnizki, J. Olsson, G. Trägårdh, Scale-up of pervaporation for the recovery of natural aroma compounds in the food industry. Part 1: simulation and performance, Journal of Food Engineering, 54 (2002) 183-195.

[2] C.C. Pereira, C.P. Ribeiro Jr, R. Nobrega, C.P. Borges, Pervaporative recovery of volatile aroma compounds from fruit juices, Journal of Membrane Science, 274 (2006) $1-23$.

[3] H.O.E. Karlsson, G. Tragardh, Applications of pervaporation in food processing, Trends in Food Science \& Technology, 7 (1996) 78-83.

[4] N. Garcia-Martin, S. Perez-Magarino, M. Ortega-Heras, C. Gonzalez-Huerta, M. Mihnea, M.L. Gonzalez-Sanjose, L. Palacio, P. Pradanos, A. Hernandez, Sugar reduction in white and red musts with nanofiltration membranes, Desalination and water treatment, 27 (2011) 167-174.

[5] N. García-Martín, S. Perez-Magariño, M. Ortega-Heras, C. González-Huerta, M. Mihnea, M.L. González-Sanjosé, L. Palacio, P. Prádanos, A. Hernández, Sugar reduction in musts with nanofiltration membranes to obtain low alcohol-content wines, Separation and Purification Technology, 76 (2010) 158-170.

[6] C.M. Salgado, L. Palacio, P. Prádanos, A. Hernández, C. González-Huerta, S. Pérez-Magariño, Comparative study of red grape must nanofiltration: Laboratory and pilot plant scales, Food and Bioproducts Processing, 94 (2015) 610-620.

[7] M. Catarino, A. Mendes, Dealcoholizing wine by membrane separation processes, Innovative Food Science \& Emerging Technologies, 12 (2011) 330-337.

[8] E. López-Tamames, N. Carro-Mariño, Y.Z. Gunata, C. Sapis, R. Baumes, C. Bayonove, Potential Aroma in Several Varieties of Spanish Grapes, Journal of Agricultural and Food Chemistry, 45 (1997) 1729-1735.

[9] S.M. Rocha, P. Coutinho, A. Barros, I. Delgadillo, M.A. Coimbra, Establishment of the varietal volatile profile of musts from white Vitis vinifera $L$. varieties, Journal of the Science of Food and Agriculture, 87 (2007) 1667-1676.

[10] C. Brazinha, V.D. Alves, R.M.C. Viegas, J.G. Crespo, Aroma recovery by integration of sweeping gas pervaporation and liquid absorption in membrane contactors, Separation and Purification Technology 70 (2009) 103-111.

[11] E.S. Palomo, M.C. Díaz-Maroto, M.A.G. Viñas, A. Soriano-Pérez, M.S. PérezCoello, Aroma profile of wines from Albillo and Muscat grape varieties at different stages of ripening, Food Control, 18 (2007) 398-403.

[12] A. Klamt, Conductor-like Screening Model for Real Solvents: A New Approach to the Quantitative Calculation of Solvation Phenomena, The Journal of Physical Chemistry, 99 (1995) 2224-2235. 
[13] A. Klamt, F. Eckert, W. Arlt, COSMO-RS: An Alternative to Simulation for Calculating Thermodynamic Properties of Liquid Mixtures, Annual Review of Chemical and Biomolecular Engineering, 1 (2010) 101-122.

[14] T. Schäfer, J.G. Crespo, Study and optimization of the hydrodynamic upstream conditions during recovery of a complex aroma profile by pervaporation, Journal of Membrane Science, 301 (2007) 46-56.

[15] R. Kopeć, M. Meller, W. Kujawski, J. Kujawa, Polyamide-6 based pervaporation membranes for organic-organic separation, Separation and Purification Technology, 110 (2013) 63-73.

[16] R.Y.M. Huang, C.K. Yeom, Pervaporation separation of aqueous mixtures using crosslinked poly(vinyl alcohol)(pva). II. Permeation of ethanol-water mixtures, Journal of Membrane Science, 51 (1990) 273-292.

[17] P. Sampranpiboon, R. Jiraratananon, D. Uttapap, X. Feng, R.Y.M. Huang, Pervaporation separation of ethyl butyrate and isopropanol with polyether block amide (PEBA) membranes, Journal of Membrane Science, 173 (2000) 53-59.

[18] Á.d. Olmo, C.A. Blanco, L. Palacio, P. Prádanos, A. Hernández, Pervaporation methodology for improving alcohol-free beer quality through aroma recovery, Journal of Food Engineering, 133 (2014) 1-8.

[19] C.M. Hansen, Hansen Solubility Parameters: A User's Handbook, Second Edition, CRC Press, 2007.

[20] J. Niemistö, W. Kujawski, R.L. Keiski, Pervaporation performance of composite poly(dimethyl siloxane) membrane for butanol recovery from model solutions, Journal of Membrane Science, 434 (2013) 55-64.

[21] S. Heitmann, V. Krüger, D. Welz, P. Lutze, Experimental Investigation of Pervaporation Membranes for Biobutanol Separation, Journal of Membrane and Separation Technology, 2 (2013) 245-262. 



\section{Chapter 8}

\section{Application of pervaporation and nanofiltration membrane processes for the optimization of sugar reduction in grape must in order to produce a full flavored low alcohol content wine}

Camila M. Salgado ${ }^{1}$, Encarnación Fernández-Fernándeż, Laura Palacio, Francisco J. Carmona ${ }^{2}$, Antonio Hernández ${ }^{1}$ and Pedro Prádanos ${ }^{1}$.

${ }^{1}$ Grupo de superficies y Materiales porosos (SMAP, UA-UVA-CSIC), Dpto. de Física Aplicada, Facultad de Ciencias, Universidad de Valladolid, 47011 Valladolid, Spain.

${ }^{2}$ Área de Tecnología de Alimentos, E.T.S. de Ingenierías Agrarias, Universidad de Valladolid, Campus La Yutera, Avda. Madrid 44, 34071 Palencia, Spain.

${ }^{3}$ Dpto. de Física Aplicada. Esc. Politécnica. Universidad de Extremadura, 1003. Cáceres, Spain. 



\section{Chapter 8. Application of pervaporation and nanofiltration membrane processes for the optimization of sugar reduction in grape must in order to produce a full flavored low alcohol content wine}

\section{Abstract}

In the present work the performance of the combination of pervaporation and nanofiltration at pilot plant scale was studied for the elaboration of a full flavored low alcohol content wine. Two processes were compared in this work in order to assess the effectiveness of PV for aroma recovery of grape must. The first process consisted of the use of a two stage NF process for the reduction of the sugar content of must. The second combined the use of PV for aroma recovery of grape must followed by the twostage NF process for sugar reduction. Six different wine samples were obtained from the must blends. Two control wines ( $\mathrm{C} 1$ and $\mathrm{C} 2$ ); two nanofiltered wines (2NF1 and 2NF2) and two pervaporated -nanofiltered wines (PV+2NF1 and PV+2NF2).

The assessment of the permeate flux showed that in terms of the PV tests the values were remarkably lower than those obtained in the previous test using the PDMS flat sheet module. Moreover, the analysis of the aromatic profile revealed that the mixture of musts (P1+R2+ aromas) corresponding to the process $\mathrm{PV}+2 \mathrm{NF}$ exhibited an aroma content more similar to the original grape must with the exception of benzaldehyde and 1-hexanol.

The wines produced were sensorial analyzed and consumers' overall liking scores showed that Sample C1 and (PV+2NF1) were the most liked. Moreover, results exhibited that consumers found the wine samples corresponding to the PV tests more similar to the control samples. The analysis of the aroma compounds of the resulting wines showed that in comparison to the most liked control wine, wines coming from the PV experiments had a more similar aromatic profile than the ones coming only from the NF tests.

Keywords:

Pervaporation, Nanofiltration, Full flavored low alcohol content wine, aromatic profile 


\subsection{Introduction}

During the ripening of grapes, most of the compounds that determine the sensory characteristics of wines are produced [1]. Along this period, the concentration of sugars, aminoacids, phenolic compounds and potassium increase, while the content in organic acids, particularly malic acid, decreases. These changes do not necessarily occur simultaneously and it would be necessary to control all of them to determine the optimal harvesting date.

Along the last years, various world winemaking regions have provided evidence of modified vine development and fruit maturation patterns as a consequence of global warming. Among the most important climate change-related effects there is a higher sugar content, lower acidities and modification of varietal aroma compounds. Fermentation of this must leads to alcoholic degrees higher than desired [2], as they may be too burning in the mouth and mask the fruity aromas and taste of wine. Premature grape harvest and winemaking should affect the final wine quality, leading to more acid and less colored wines, because the phenolic maturity would not be yet fully achieved [3]. Therefore, in order to produce a full flavored wine, the harvest should be carried out when the optimum ripeness of the fruits has been reached and innovative techniques should be applied to musts to control their sugars to keep the final alcohol degree within the desired range.

Several studies have successfully used membrane processes, specifically nanofiltration (NF) for sugar control in beverages such as grape must [3-7]. Moreover, in our previous studies the performance of single- stage and two-stage NF processes for sugar control in red and white grape musts were compared at a pilot plant scale (see Chapter 6). Results showed that the best NF technique was a two-stage NF process. It promoted a higher recovery of the chemical properties of grape must and less volume losses before fermentation. But the sensory evaluation of the white wines obtained showed that they were less persistent in mouth and had lower flavor in comparison to the control wines. This aroma depletion was attributed to the possible loss of volatile compounds (primary aroma compounds) during grape must NF.

In order to minimize the resulting impairment of the aroma and flavor quality of the final wine, primary aroma compounds could be recovered from the grape juice before NF and then added back to the filtered must before fermentation. Traditional aroma recovery processes such as distillation, adsorption and solvent extraction are not advisable since they operate at high temperatures [8] which could deteriorate the feed and its aromas. In view of their intrinsic characteristics, namely high selectivity and possibility of operation at moderate temperatures, pervaporation (PV) is a membrane 
process that seems highly appropriate for the separation of dilute species in liquid solutions [9, 10]. Specifically, organophilic PV membranes have a high potential for recovering natural and natural-identical aroma compounds, highly diluted in complex aqueous media [11].

In our previous work (refer to Chapter 7), different PV experiments were carried out in flat sheet configuration at laboratory scale. In them PEBA and PDMS membranes were tested for aroma recovery of natural grape must and of a model solution containing the main aromas characterizing musts. Results showed that among the membranes studied, the PDMS one presented an appropriate performance.

The scope of the present research is to optimize sugar reduction in grape must, using NF and PV, in order to produce a full flavored white wine with reduced alcohol content. In that sense two aspects of the previously studied two-stage NF process will be addressed. First, the use of PV for aroma recovery of grape must before NF and fermentation will be assessed in order to minimize aroma depletion. Second, the time required for the NF procedure will be reduced by improving the NF set up described elsewhere [7].

\subsection{Materials and Methods}

\subsubsection{Pervaporation experimental set up}

Aroma recovery of grape must prior to NF was carried out in a pilot plant scale unit equipped with a PV spiral wound module (SWM). The installation built for the experiments is schematized in Figure 8.1. It consisted in a 60L stainless steel feed vessel equipped with a TAE 051 water chiller to assure that the must is kept at constant temperature. The feed was extracted from the feed reservoir by means of a Tuthill gear pump. Two manometers were placed before and after the SWM to measure the inlet and outlet pressure. The upstream tubing was made of Teflon and the metal used in the permeate stream piping was stainless steel. The vacuum conditions in the downstream side were assured by a vacuum pump from Agilent Technologies. The unit was equipped with a vacuum pressure transducer from MKS, giving the permeate pressure, $p_{\text {perm }}$, independently from the nature of the gas or vapor in presence. The condenser system consisted in two cold traps immersed in liquid nitrogen connected in parallel by three-way valves. This system allowed to take permeate samples at different filtration times. 


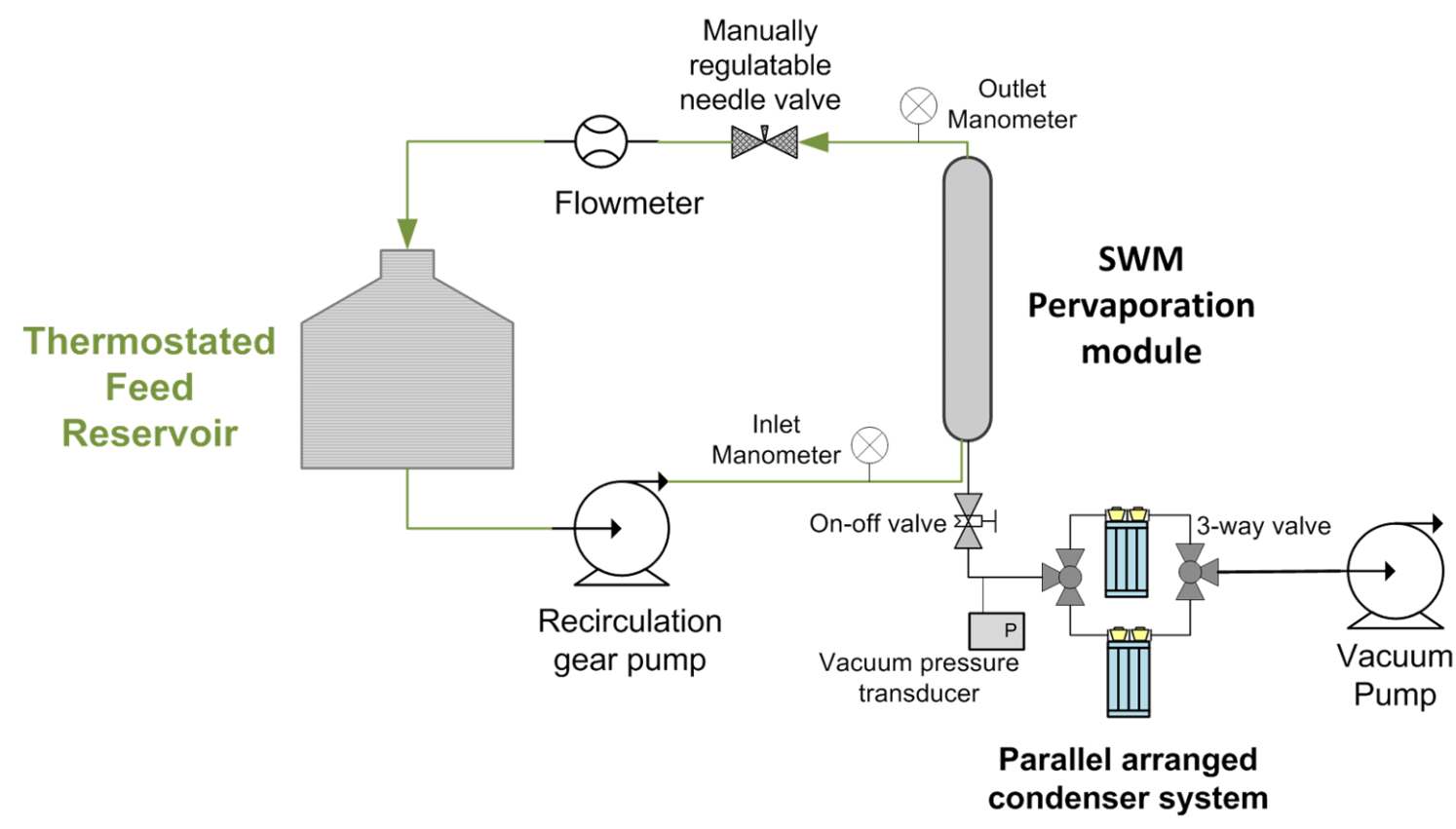

Figure 8.1. Experimental set-up used for the pervaporation of must

The PV SWM used was a PV-SR1 with a PDMS based membrane inside made and commercialized by Pervatech. The main characteristics of it are shown in Table 8.1 .

Table 8.1. Main characteristics of the PV-SR1 pervaporation Spiral Wound Module

\begin{tabular}{|c|c|c|c|c|c|c|c|c|c|}
\hline $\begin{array}{l}\text { Max. P } \\
\left(10^{5} \mathrm{~Pa}\right)\end{array}$ & $\begin{array}{r}\text { Max. } \Delta P \\
\left(10^{5} \mathrm{~Pa}\right)\end{array}$ & $\begin{array}{c}\mathrm{pH} \\
\text { range }\end{array}$ & $\begin{array}{c}\text { Max } \\
\cdot \mathrm{T} \\
\left({ }^{\circ} \mathrm{C}\right)\end{array}$ & $\begin{array}{c}\text { Active } \\
\text { membrane } \\
\text { Area } \\
A_{m}\left(\mathrm{~m}^{2}\right)^{\mathrm{a}}\end{array}$ & $\begin{array}{l}\text { Module } \\
\text { Length } \\
L(\mathrm{~m})^{\mathrm{a}}\end{array}$ & $\begin{array}{l}\text { Module } \\
\text { diameter } \\
(\mathrm{m})^{\mathrm{a}}\end{array}$ & $\begin{array}{l}\text { Leaf } \\
\text { with } W \\
(\mathrm{~m})^{\mathrm{b}}\end{array}$ & $\begin{array}{c}\text { Feed } \\
\text { spacer } \\
\text { height } \\
H \\
\left(10^{-3} \mathrm{~m}\right)^{\mathrm{a}}\end{array}$ & $\begin{array}{c}\text { Feed } \\
\text { spacer }^{\text {a }} \text { porosity }^{\mathrm{a}} \\
\varepsilon\end{array}$ \\
\hline 3 & 1 & $3-8$ & 80 & 0.550 & 0.505 & 0.062 & 0.545 & 2.000 & 0.750 \\
\hline
\end{tabular}

${ }^{a}$ Provided by the manufacturer

${ }^{\mathrm{b}}$ Own determination

As mentioned, the selection of the PDMS membrane and module was based on the results obtained in a previous work (refer to Chapter 7), testing the performance of different organophillic PV membranes in flat sheet configuration. Results showed that among the membranes studied, the PDMS presented an appropriate performance for aroma recovery of grape juice.

\subsubsection{Nanofiltration experimental set up}

Grape must nanofiltrations were performed in a pilot plant scale unit with two NF SWMs arranged in parallel. The experimental set-up used is shown in Figure 8.2. It 
consisted in the same thermostated 60L stainless steel feed vessel used for the PV test. The feed was extracted from the reservoir by means of a diaphragm pump Hydra - Cell D25. Two pressure transducers were placed before and after the SWM configuration to measure the inlet and outlet pressure. In order to adjust manually the pressure inside the module a needle valve was placed at the exit of the unit. Cross flow was adjusted through this valve and the speed control of the pump. The retentate flow rate was measured with a flowmeter ranging from 0 to $150 \mathrm{~L} / \mathrm{min}$. The permeate flux was monitored using a multi-tube flow system with flow capacity from 0 to $10 \mathrm{~L} / \mathrm{min}$.

The NF membranes used in the spiral wound configuration were the KMS SR3 (reference 3839 SR3- NYV), made and commercialized by Koch Membrane Systems. The selection of the SR3 membrane was based on previous experiments testing different nanofiltration membranes in flat sheet configuration using commercial musts [12].The main characteristics of the membrane and SWM have already been exposed in our previous work [7] where a single SWM was used for the filtration of natural grape must.

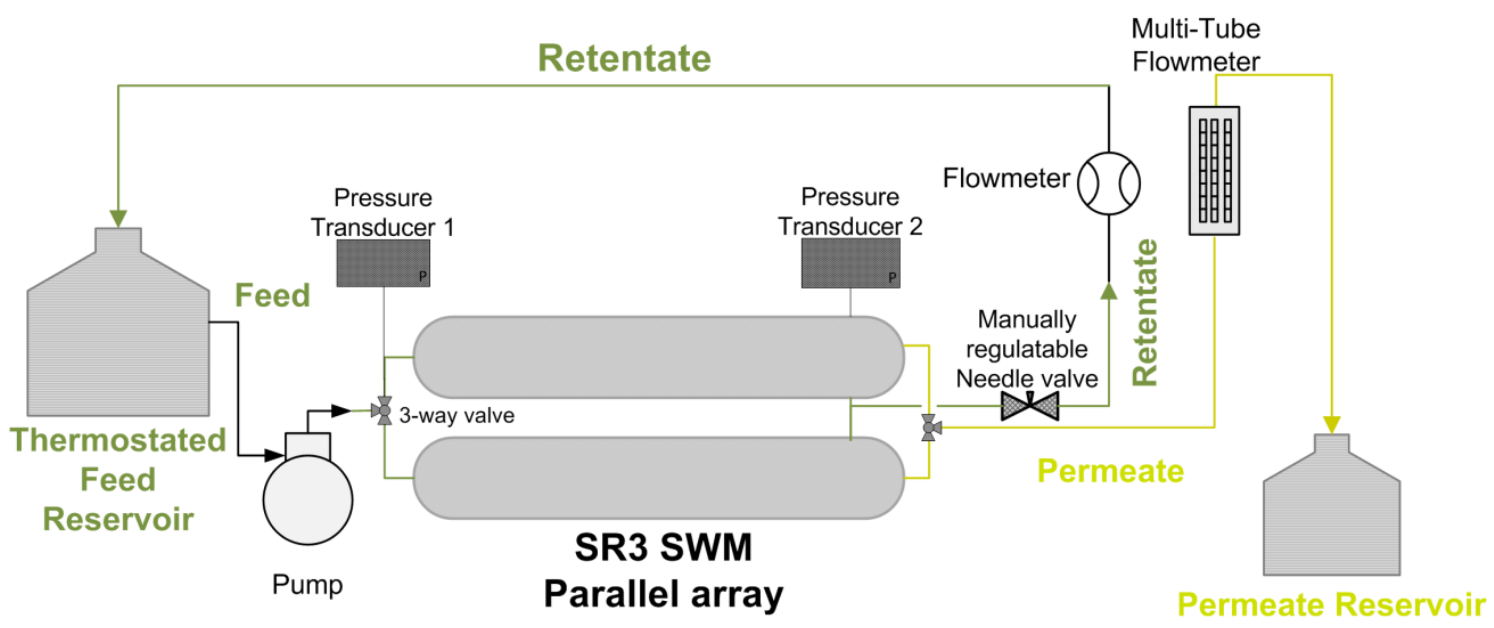

Figure 8.2 Experimental set-up used for the nanofiltrations of must

\subsubsection{Verdejo white grape must}

The grapes used for the experiments came from a Spanish white variety named Verdejo. They were cultivated in the experimental vineyard of the Institute of Agricultural Technology of Castilla y León (fields of Zamadueñas and Rueda, Valladolid, Spain) from the 2013 vintage. Nearly $700 \mathrm{~kg}$ of Verdejo grapes were transported in plastic boxes of $15 \mathrm{~kg}$ to the experimental wine cellar of the Agricultural Engineering School (University of Valladolid, Palencia, Spain), where the musts were elaborated. The fruits were destemmed, crushed, sulphited and pressed to obtain the respective must. Potassium metabisulphite was added $\left(40 \mathrm{mg} / \mathrm{L}\right.$ of $\left.\mathrm{SO}_{2}\right)$ in order to 
prevent oxidation or spoilage caused by bacteria. Pectolytic enzymes $(10 \mathrm{mg} / \mathrm{L}$ of Enozym Altair, Agrovin) were added to enhance first clarification. The cleared must was filtered through 3 and $0.8 \mu \mathrm{m}$ cellulose filter plates in order to prevent ulterior membrane fouling.

After this, the content of total sugars (glucose and fructose), density viscosity, and main oenological parameters were determined. Some of these results are presented in Table 8.2 and the oenological properties of this must are shown in Table 8.4 as control must $(C)$.

Grape must contains a great number of aromatic compounds making their identification, quantification and analysis very complicated. Therefore six of the most important aroma compounds of must, as found in the literature [13-15], have been studied in our previous work and also in this research. These compounds are: hexanal (HexAL), isoamylalcohol (i-AmOL), 1-hexanol (1-HexOL), benzaldehyde (BezAL), benzylalcohol (BezOL) and 2-phenylethanol (2-PhetOL). The concentration of them is exhibited in Table 8.2.

Table 8.2. Original composition of pre-filtered Verdejo grape must

\begin{tabular}{|c|c|c|c|c|c|c|c|c|c|}
\hline & \multirow[b]{2}{*}{$\begin{array}{c}\text { Total } \\
\text { Sugars } \\
\left(g^{-1}\right)\end{array}$} & \multirow[b]{2}{*}{$\begin{array}{c}\rho^{a} \\
\left(\mathrm{kgm}^{-3}\right)\end{array}$} & \multirow[b]{2}{*}{$\begin{array}{c}\eta^{b} \\
\left(10^{-3} \text { Pas }\right)\end{array}$} & \multicolumn{6}{|c|}{ Aroma compound (ppb) } \\
\hline & & & & $\begin{array}{l}\frac{1}{4} \\
\underset{\Phi}{\Phi} \\
\text { I }\end{array}$ & 론 & $\begin{array}{l}\overrightarrow{1} \\
0 \\
\mathbb{x} \\
\stackrel{1}{1} \\
r\end{array}$ & $\underset{\substack{\alpha \\
\Phi}}{\mathbb{d}}$ & $\begin{array}{l}\overrightarrow{1} \\
\underset{\mathbb{N}}{\mathbf{m}}\end{array}$ & $\begin{array}{l}\vec{d} \\
\frac{1}{0} \\
\frac{c}{\alpha} \\
\frac{1}{N}\end{array}$ \\
\hline $\begin{array}{c}\text { Verdejo } \\
\text { grape } \\
\text { must }\end{array}$ & $215 \pm 9$ & $\begin{array}{c}1092.2 \\
6\end{array}$ & 1.517 & $\begin{array}{c}8.06 \pm \\
0.73\end{array}$ & $\begin{array}{c}188 \pm \\
13\end{array}$ & $\begin{array}{c}1372 \pm \\
9\end{array}$ & $\begin{array}{c}23.5 \pm \\
1.8\end{array}$ & $\begin{array}{c}19 \pm \\
7\end{array}$ & $\begin{array}{c}68 \pm \\
6\end{array}$ \\
\hline
\end{tabular}

The portions of musts that were going to be used for the filtration experiments were transported in stainless steel vessels to the Laboratory of Membrane Processes of the Faculty of Science (University of Valladolid, Valladolid, Spain). The remaining volumes of musts were kept as control musts in the cold chamber (at $4^{\circ} \mathrm{C}$ in airtight vessels) of the Agricultural Engineering College (University of Valladolid, Palencia, Spain).

\subsubsection{Experimental Procedure}

Two processes were studied and compared in this work in order to assess the effectiveness of PV for aroma recovery of grape must before sugar reduction using NF. The first process consisted in the use of a two stage NF process for the reduction of 
the sugar content of must. The second combined the use of PV of grape must for aroma recovery followed by the two-stage NF process for sugar reduction.

A scheme that summarizes the steps and operating conditions of each process and the combination of them is depicted in Figure 8.3.

\subsubsection{Pervaporation}

During this experiment the operating parameters controlled (refer also to the dashed blue arrows in Figure 8.3) were: temperature of the feed stream, $T_{\text {feed }}=16 \pm 1$ $\circ \mathrm{C}$, temperature of the condenser, $T_{\text {condens, }}$ which was kept constant at $-196 \circ \mathrm{C}$. The downstream pressure was kept constant at $p_{\text {perm }}=0.6 \pm 0.2 \mathrm{kPa}$ and the feed flow rate was set to $4 \mathrm{~L} / \mathrm{min}$. According to the flow conditions in a SWM explained in a previous work [7] and the spacers dimensions shown in Table 8.1, this corresponds to an effective velocity, of $8.16 \cdot 10^{-2} \mathrm{~ms}^{-1}$. Moreover, according to this work and the properties of grape must (Table 8.2) this tangential velocity corresponded to a Reynolds number of 88.14 in the SWM. This Re number exceeds the transition state as mentioned by Koutsou and coworkers [18] assuring turbulent flow.

In order to minimize the depletion of aromas during each experiment the feed vessel was kept closed and with a small headspace.

Before the test the PV membrane was conditioned. Here, the PDMS membrane was treated by filtering Milli-Q (Merck Millipore) water under the same operating conditions. In this case, the experiment lasted for $2 \mathrm{~h}$.

$50 \mathrm{~L}$ of grape must were pervaporated during $6 \mathrm{~h}$. Three different permeates (PV1, PV2 and PV3) and retentates were collected every two hours alternately in the two cold traps of the condenser system. Samples were taken analyzed by gas chromatography.

After the PV experiment the retentate was submitted to the 2-stage NF process, described in the next section, for sugar reduction. The permeates were kept in freezing conditions until the appropriate mixture before fermentation (see Figure 8.3).

\subsubsection{Two-stage nanofiltration}

This process consisted of the same sequence of steps mentioned in the previous works presented elsewhere [3, 7, 19] (see also Chapter 6). Operating conditions were modified in order to reduce the filtration time. For this purpose, the membrane active area $\left(A_{m}=7.1 \mathrm{~m}^{2}\right)$ was increased in the first stage using two SWM arranged in parallel. Besides, the feed flow was increased by means of a larger diaphragm pump. 
Operating conditions are presented in Figure 8.3. It is important to remark that the recirculation flow in the first stage was of $50 \mathrm{~L} / \mathrm{min}(25 \mathrm{~L} / \mathrm{min}$ in each module) and $30 \mathrm{~L} / \mathrm{min}$ in the second. According to the equations and the spacers dimensions shown in a previous work [7] these correspond to an effective velocity, of $1.75 \cdot 10^{-1} \mathrm{~ms}^{-1}$ per module in the first stage and $2.09 \cdot 10^{-1} \mathrm{~ms}^{-1}$ in eachmodule ${ }^{-1}$ in the second.

For both processes ( 2 stage- NF and PV followed by 2 stage- NF), the second permeate (P2) was mixed with the first retentate (R1) in appropriate proportions to produce the intended moderate reduction in the alcohol degree of the final wine. This mixture preserves the specific grape features linked to the high molecular weight components retained in $\mathrm{R} 1$ but with a lower sugar concentration.

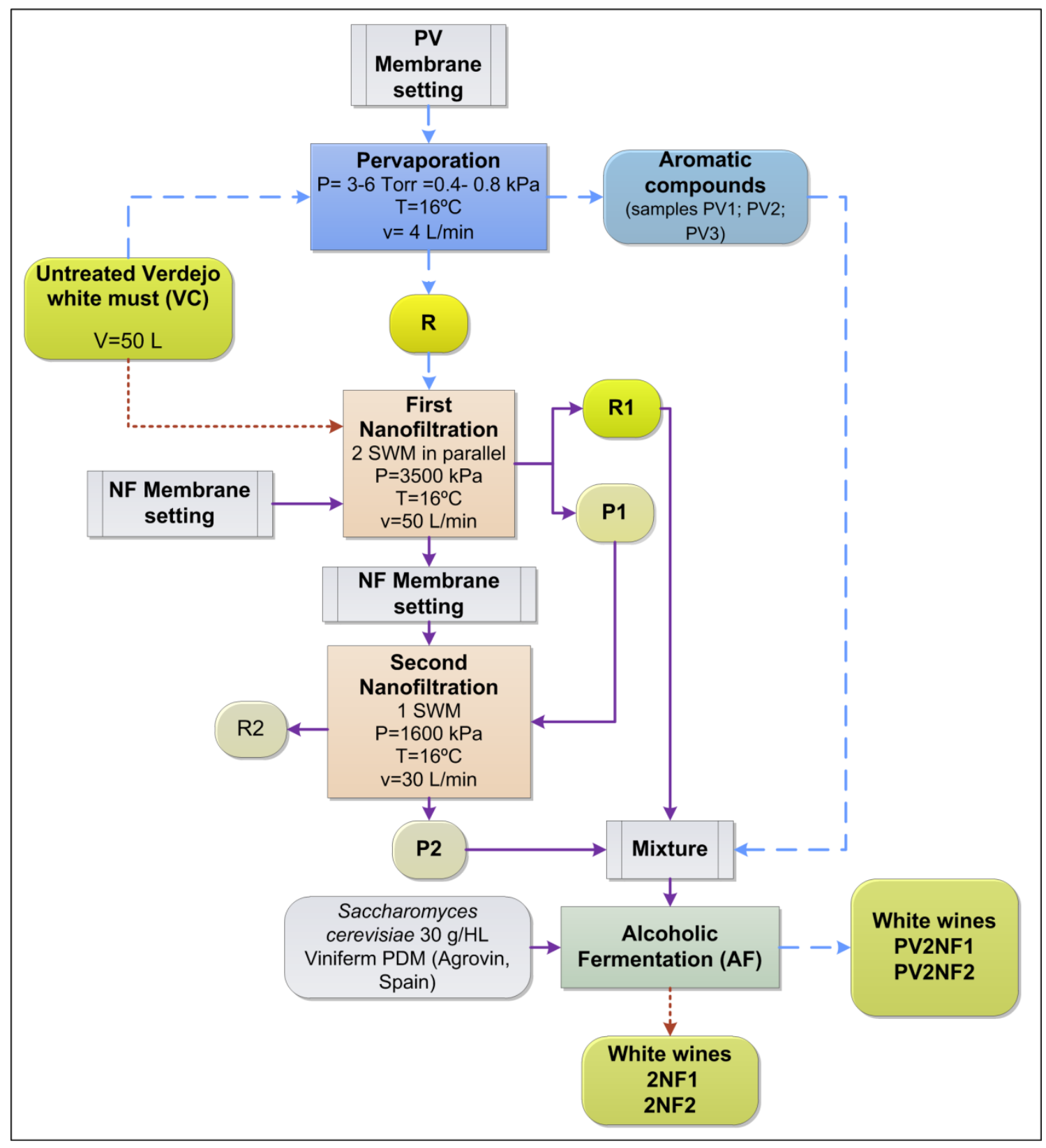

Figure 8.3. Experimental steps carried out during the different methods proposed 


\subsubsection{Elaboration of the corresponding wines}

The elaboration of wines was carried out at the experimental cellar of the Agricultural Engineering School (University of Valladolid, Palencia, Spain). Three different Verdejo white wines were manufactured: A control obtained from the control must $(C)$, and two low alcohol content wines: one made from the mixture coming from the two-stage nanofiltration $(P 2+R 1)$ and one produced from the mixture (P2+R1+Aromatic compounds) obtained from the pervaporation followed by the twostage nanofiltration process (see Figure 8.3).

Fermentations were performed by duplicate. This means that each must or mixture was divided in two and fermented in separated vessels. In this way six different wine samples were obtained: two control wines (C1 and $C 2)$; two nanofiltered wines (2NF1 and 2NF2) and two pervaporated -nanofiltered wines (PV+2NF1 and PV+2NF2).

All white wines were manufactured following the corresponding traditional procedure detailed in Figure S8.1 of the supporting material.

\subsubsection{Analytical Methods}

\subsubsection{Oenological parameters}

As mentioned, the main oenological parameters of verdejo musts and corresponding wines were determined according to the principles and methods summarized in Table 8.3.

Table 8.3. Methods used for the determination of some oenological parameters of musts.

\begin{tabular}{|c|c|c|}
\hline Parameter & Principle & Method \\
\hline $\begin{array}{l}\text { Glucose and } \\
\text { Fructose }\end{array}$ & $\begin{array}{c}\text { Ion exchange } \\
\text { Chromatography }\end{array}$ & HPLC \\
\hline $\begin{array}{c}\text { Tartaric and Malic } \\
\text { Acid }\end{array}$ & Chromatography & HPLC \\
\hline $\mathrm{pH}$ & Potentiometry & $\mathrm{pH}$ - meter \\
\hline Volatile acidity & Acid- base titration & García-Tena $^{a}$ \\
\hline Total acidity & $\begin{array}{l}\text { Potentiometric } \\
\text { titration }\end{array}$ & OIV $^{b}$ \\
\hline $\mathrm{SO}_{2} \mathrm{~T}$ and $\mathrm{SO}_{2} \mathrm{~F}$ & Iodometry & Ripper automated \\
\hline Alcoholic degree & Ebullometry & Barus apparatus $^{c}$ \\
\hline Total Polyphenols & UV absorbance & UV/Vis spectrophotometry \\
\hline Color & Vis absorbance & UV/Vis spectrophotometry ${ }^{b}$ \\
\hline
\end{tabular}

${ }^{\mathrm{a}}[20] ;{ }^{\mathrm{b}}[21] ;{ }^{\mathrm{c}}[22]$;

$\mathrm{SO}_{2} \mathrm{~T}$ : Total $\mathrm{SO}_{2} ; \mathrm{SO}_{2} \mathrm{~F}$ : Free $\mathrm{SO}_{2}$ 
The chromatographic system used consisted in an HPLC apparatus from Waters with a Refractive Index detector Waters 2414, an isocratic pump Waters 1515, the Waters 1707 Autosampler, and a thermostated column compartment together with the software Breeze 2. A Supelco Supelcogel Pb guard column and column were used for the sugars (glucose and fructose) separation and a Shodex DE-413 guard column and column for malic and tartaric acid detection.

Total and Free $\mathrm{SO}_{2}$ were determined by iodometry according to the Ripper method [20]. This technique was automated by means of an SO2- Matic 23 apparatus from Crison.

Alcohol Degree of wines was measured by ebulliometry [22] using a Barus apparatus from GAB System.

UV/Vis spectrophotometric methods were performed using the UV/Vis spectrophotometer (Lan Optics 2000 UV, Labolan, Spain).

\subsubsection{Volatile compounds}

Solid-phase microextraction (SPME) was used to analyze the volatile compounds of samples coming from grape must and also of the corresponding wines.

Extracts were analyzed by an Agilent Technologies Gas chromatography-mass spectrometry system (GC-MS).

In the case of samples coming from grape juice, an SPME device from Supelco (Sigma-Aldrich Corporation) with a $10 \mathrm{~mm}$ fiber coated with $65 \mu \mathrm{m}$ polydimethylsiloxane/divinylbenzene (PDMS/DVB) was used. The gas chromatograph was equipped with a HP-INNOWax capillary column $(60 \mathrm{~m} \times 0.25 \mathrm{~mm}$ i.d. $\times 0.5 \mu \mathrm{m})$ from Agilent and the carrier gas used was helium at a flow of $1.2 \mathrm{~mL} \mathrm{~min}^{-1}$. The conditions for the extraction of the volatile compounds were: $2 \mathrm{~mL}$ of the sample were transferred to a $4 \mathrm{~mL}$ vial; the ionic strength was adjusted with $0.8 \mathrm{~g} \mathrm{NaCl}$. The vial was sealed and the headspace extraction was performed for $60 \mathrm{~min}$ at $50^{\circ} \mathrm{C}$ keeping the sample under continuous stirring. After this, the fiber was withdrawn into the needle, removed from the vial and inserted into the injector of the GC-MS system in splitless mode at $270^{\circ} \mathrm{C}$ for $15 \mathrm{~min}$. The GC oven temperature was programmed from $40^{\circ} \mathrm{C}$ (held for $2 \mathrm{~min}$ ) to $215^{\circ} \mathrm{C}$ at $3.1^{\circ} \mathrm{C} \min ^{-1}$ (held for $3 \mathrm{~min}$ ) and then to $250 \stackrel{\circ}{\circ} \mathrm{C}$ at $10 \stackrel{\circ}{\circ} \mathrm{min}^{-1}$.

For the extraction of wine samples, a $10 \mathrm{~mm}$ fiber coated with $100 \mu \mathrm{m}$ polydimethylsiloxane (PDMS) was used. The gas chromatograph was equipped with a HP-5MS capillary column ( $30 \mathrm{~m} \times 0.25 \mathrm{~mm}$ i.d. $\times 0.25 \mu \mathrm{m}$ ) from Agilent, and the carrier gas used was helium ( $1 \mathrm{~mL} \mathrm{~min}^{-1}$ constant flow). The SPME parameters used were as described by Zhang and coworkers [23]. Specifically, $5 \mathrm{~mL}$ of wine were added to a 15 $\mathrm{mL}$ glass vial and the ionic strength was adjusted with $1.5 \mathrm{~g} \mathrm{NaCl}$. The optimized 
extraction of volatiles from the wine headspace consisted in exposing the fiber at $40{ }^{\circ} \mathrm{C}$ for 30 min keeping the sample under continuous stirring. After this, the volatiles were desorbed in a splitless injector at $250{ }^{\circ} \mathrm{C}$ for $10 \mathrm{~min}$ and transferred directly to the analytical column. The GC oven temperature was programmed from $40 \stackrel{\circ}{\mathrm{C}}$ (held for $3 \mathrm{~min}$ ) at $2{ }^{\circ} \mathrm{C} \min ^{-1}$ to $120^{\circ} \mathrm{C}$ (for $1 \mathrm{~min}$ ), then at $4{ }^{\circ} \mathrm{C} \min ^{-1}$ to $200{ }^{\circ} \mathrm{C}$ (for $1 \mathrm{~min}$ ), then at $12 \stackrel{\circ}{\circ} \mathrm{Cmin}^{-1}$ to $250 \stackrel{\circ}{\mathrm{C}}$ (for $2 \mathrm{~min}$ ).

Agilent MSD ChemStation D.01.00 Build 75 (26-Aug-2003) software was used to acquire the GC/MS data. Compounds were identified by matching the mass spectra of the unknown peaks with the data stored in the Wiley Registry of Mass spectral Data, $7^{\text {th }}$ Edition (Agilent Part No.1730 A) library.

In the case of samples coming from grape juice, the main aromatic compounds (i.e.Hexanal, isoamylalcohol, 1-Hexanol, Benzaldehyde, Benzylalcohol and 2Phenylethanol) were confirmed and quantified by standard curves obtained by the SPME of pure commercially available standards injected under the same conditions.

\subsubsection{Consumer sensory test}

Sensory evaluation of the wines was conducted with 20 oenology student volunteers from 18 to 44 years old and with previous experience in wine tasting.

Consumer tests were carried out in the Sensory Science Laboratory of the Agricultural Engineering College at the University of Valladolid, Palencia (Spain), in individual booths.

Consumers tasted the samples served sequentially and monodically, using randomized complete block design. Samples were presented in wine- tasting glasses coded with 3-digit random numbers and served in a randomized order. Water and crackers were available for rinsing.

The sensory analysis session for each panelist consisted in three tests which will be briefly explained.

\subsubsection{Overall liking}

In the first study consumers were asked to try each of the wines and to evaluate their overall liking using a 9-point hedonic scale. The scale of values ranged from "like extremely" to "dislike extremely" corresponding to the highest and lowest scores of 9 and 1 , respectively. 


\subsubsection{Intensity scales}

Asking consumers to rate the intensity of different sensory attributes using scales has been reported as an appropriate alternative to the sensory profile that trained assessors could provide [24].

In this task, consumers had to rate the intensity of nine sensory attributes using a $10 \mathrm{~cm}$ unstructured line scale from 0 to 10 . The attributes considered were the following: color, odor, volume in mouth, bitter, acid, fruity, fennel, herbaceous and persistence in mouth.

\subsubsection{Projective mapping}

The third and last study corresponded to the projective mapping task, also known as Napping ${ }^{\circledR}$ [25]. This method has been used to quantify individual perception of overall similarity and dissimilarity between products. In this methodology consumers are asked to provide a two dimensional projection of a group of samples, according to their own criteria [24]. Here consumers were first asked to try each of the wines. After this, consumers were asked to place the samples on a $60 \times 40 \mathrm{~cm}$ white sheet according to the similarities or dissimilarities between them. Consumers were explained that they had to complete the task according to their own criteria and that there were no right or wrong answers. They were also explained that samples close together on the sheet would correspond to very similar wines and that if they perceived samples as very different they had to locate them very distant from each other. Only for this study, consumers were briefly told about the wine making and membrane process involved for samples production. In this case, information was provided in order to evaluate the influence of membrane processes in consumers 'perception.

For each consumer map, the $X$ and $Y$ coordinates of each sample were determined, considering the left bottom corner of the sheet as origin of the coordinate system.

\subsubsection{Data analysis}

Descriptive statistics (mean, standard deviation) were calculated for each of the descriptors evaluated using hedonic and intensity scales. An analysis of variance (ANOVA) was performed with the hedonic data using the statistical program SPSS Statistics version 20.0. The Tukey test was used to determine statistically significant differences between the means. Confidence intervals of $95 \%$ or a significant level of $p$ $=0.05$ were used.

For intensity scales, a principal component analysis (PCA) was carried out on the data matrix composed of the means of consumers data $x$ samples. Statgraphics 
Plus for Windows 4.0 (Statistical Graphics Corp., Rockville, MD 20852-4999 USA) was used for data processing.

Data from the projective mapping task consists on the $X$ and $Y$ coordinates of the wines in the white sheet, for each consumer. These data were analyzed using Multiple Factor Analysis (MFA), to allow an study of the different aspects of such a data set [25]. For data analysis, $R$ programming language [26] and the $R$ package FactoMineR were used.

\subsection{Results and Discussion}

\subsubsection{Pervaporation experiments}

The permeate flux, $J_{\mathrm{i}}$, which is the flow rate of permeate of the $\mathrm{i}$-th component per unit of membrane area expressed in $\mathrm{gh}^{-1} \mathrm{~m}^{-2}$. Based on the mass of grape must that permeated through the PV membrane area every 2 hours, the instantaneous overall flux $J_{\text {tot,j }}$ and also the global flux $J_{\text {tot }}$ during the experimental time (6 hours) were calculated. In this way, the global permeation of grape juice was $J_{t o}=73.97\left(\mathrm{gh}^{-1} \mathrm{~m}^{-2}\right)$. This value was more than 10 times lower than the global value obtained in the previous test using the PDMS flat sheet module: $987.30\left(\mathrm{gh}^{-1} \mathrm{~m}^{-2}\right)$ (see Chapter 7). This decrease is only attributable to the difference in the configuration of the modules used. On one hand the configuration in a SWM modifies the effectivity of the vacuum in the permeate side. On the other hand, as mentioned elsewhere [7] the presence of spacers modifies the hydrodynamic conditions in the retentate side modifying concentration polarization and fouling effects. Figure $8.4 \mathrm{a}$ shows permeate flux decrease every 2 hours. It can be appreciated that there is a remarkable decrease of $J_{\text {tot,j }}$ during the first period followed by a less sharp decrease suggesting that a more or less constant permeate flux could be reached. This decay can be attributed to the process of membrane fouling and also to the reduction of the concentration of volatile compounds in the retentate side.

By using the permeate mass fraction of the i-th component in the permeate, the partial flux of each aroma compound $J_{i}$ was calculated along the pervaporation process. Results are shown in Figure $8.4 \mathrm{~b}$. The partial fluxes obtained here were between 2 and 3 orders of magnitude lower than those for the flat sheet module. Nevertheless, the same trend of permeation was detected, i.e. the passage of alcohols through the membrane is higher than that of aldehydes. Additionally it may be appreciated that alcohols present a decreasing trend along the complete process. This is, possibly because a very quick saturation of the membrane and the decrease of the 
concentration of these compounds with time in the retentate. In contrast, aldehydes exhibit a maximum at intermediate filtration time values. This may be due to their lower affinity for the polymer, making the process of saturation of the membrane slower. Although, as mentioned in Chapter 7, the permeability of aldehydes within grape must seems to be strongly influenced by the interactions of these compounds with other molecules or macromolecules present in the media.
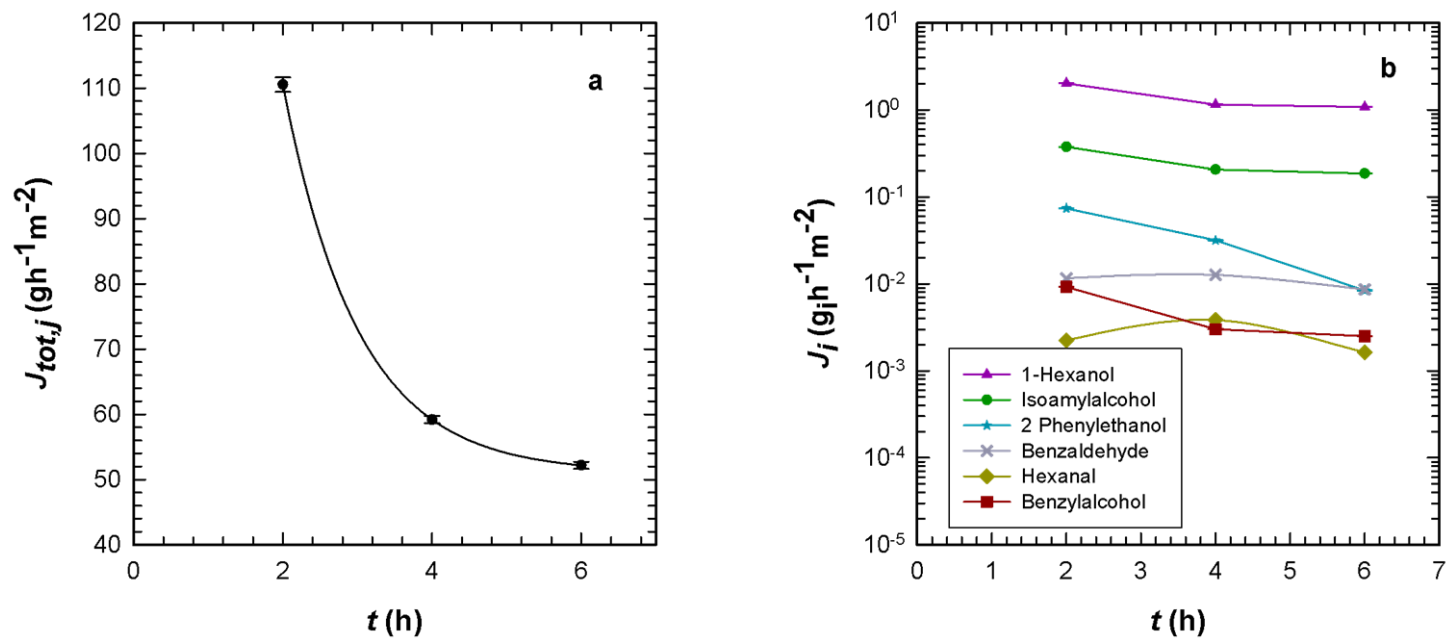

Figure 8.4 Time evolution of the total permeate flux $\left(J_{\text {tot }, j}\right)$ (a) and partial fluxes of each aroma compound (b) along pervaporation of grape must

The performance of a PV membrane is often described by the separation capacity along the process. In order to quantify this, the mass concentration enrichment factor, $\beta_{i}$, for the component $i$ is defined as the ratio of the mass concentration of $\mathrm{i}$ in the permeate $C_{\mathrm{P}, \mathrm{i}}$ and the mass concentration of $\mathrm{i}$ in the feed, $C_{\mathrm{f}, \mathrm{i}}$ :

$$
\beta_{i}=\frac{C_{P, i}}{C_{F, i}}
$$

The ratio of enrichment factors of a compound $i$ and a compound $j$ indicates the selectivity or separation factor, $a_{i, j}$, that a membrane has for a compound $i$ in comparison with compound $\mathrm{j}$ :

$$
\alpha_{i, j}=\frac{\beta_{i}}{\beta_{j}}
$$

Since grape juice is a complex matrix, selectivity was defined as the separation of each aroma towards the compounds present in grape juice except the aromas 
studied. The results obtained for these performance parameters are plotted in Figure 8.5. Here, it can be observed that the enrichment and separation factors decrease with PV time for ilsoamylalcohol, hexanal, 2 phenylethanol and benzaldehyde. This suggests a good trend of recovery of these solutes along the process. In the case of hexanol and benzylalcohol a progressive increase of these factors is shown but no decrease is observed. This means that the depletion of these aromas is not achieved during the experimental time studied.
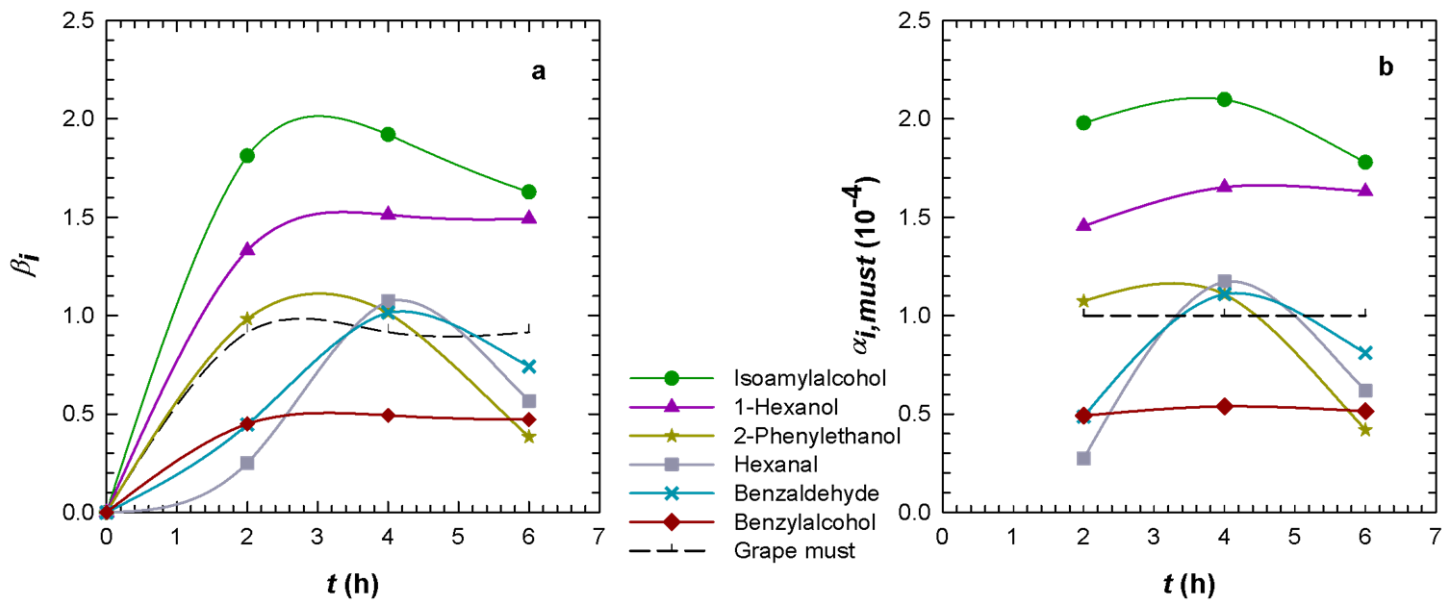

Figure 8.5 Time evolution of enrichment $\left(\beta_{i}\right)(a)$ and separation $\left(\alpha_{i, m u s t}\right)$ (b) factors of each aroma compound along the pervaporation process Dashed lines correspond to the factors when $\mathrm{j}$ represents must except the aromas analyzed $(\mathrm{j}=\mathrm{i})$

Once again the values obtained for these performance parameters are about 10 times lower than the respective values calculated in the previous test using the PDMS flat sheet module (see Chapter 7). This was expected due to the lower fluxes mentioned before.

The results obtained for these parameters, compared with those obtained in our lower-scale studies, suggest that mass transfer should be enhanced in the SWM (even though turbulent conditions were assured).

\subsubsection{Nanofiltration experiments}

As shown in Figure 8.3, the two-stage nanofiltration process is common to both filtration methods studied. The only difference was the feed which in one case consisted of the original must and in the other it was the same must but with a lower aromatic profile (retentate of the PV process). This difference should not affect the NF process. Figure 8.6 shows the kinetics of permeate flow, which is therefore representative of two methods. Green filled circles correspond to the first NF- stage 
while white filled circles represent the second NF- stage. The permeate flux decrease for both stages showed the same trend as observed in previous studies using the same grape juice variety in Chapter $6[3,19]$. Here, the initial flow of the first- stage is considerably lower than the initial one of the second-stage. The presence of high molecular weight compounds in the feed of the first process increases the effects on permeate flux decrease of the increase of viscosity, osmotic pressure difference and membrane fouling. Although these parameters have the same influence during the second filtration, their effect on permeate flux is smaller since the feed is mainly composed of low molecular weight molecules.

It is important to remember that one of the aims of this research is to reduce the NF time necessary for the intended sugar reduction. Therefore, in comparison to our previous studies [7], the effective membrane area was increased in the first NF-stage and the effective crossflow velocity was increased in both stages. Figure 8.6 shows that the initial permeate flux of the first stage is around two times higher: $2.36 \cdot 10^{-7} \mathrm{~ms}^{-1}$ vs $5.31 \cdot 10^{-7} \mathrm{~ms}^{-1}$ and around four times for the second stage $\left(11.80 \cdot 10^{-7} \mathrm{~ms}^{-1}\right.$ vs $47.21 \cdot 10^{-7} \mathrm{~ms}^{-1}$ ) (see Chapter 6 ). In this way the filtration times required were also remarkably decreased.

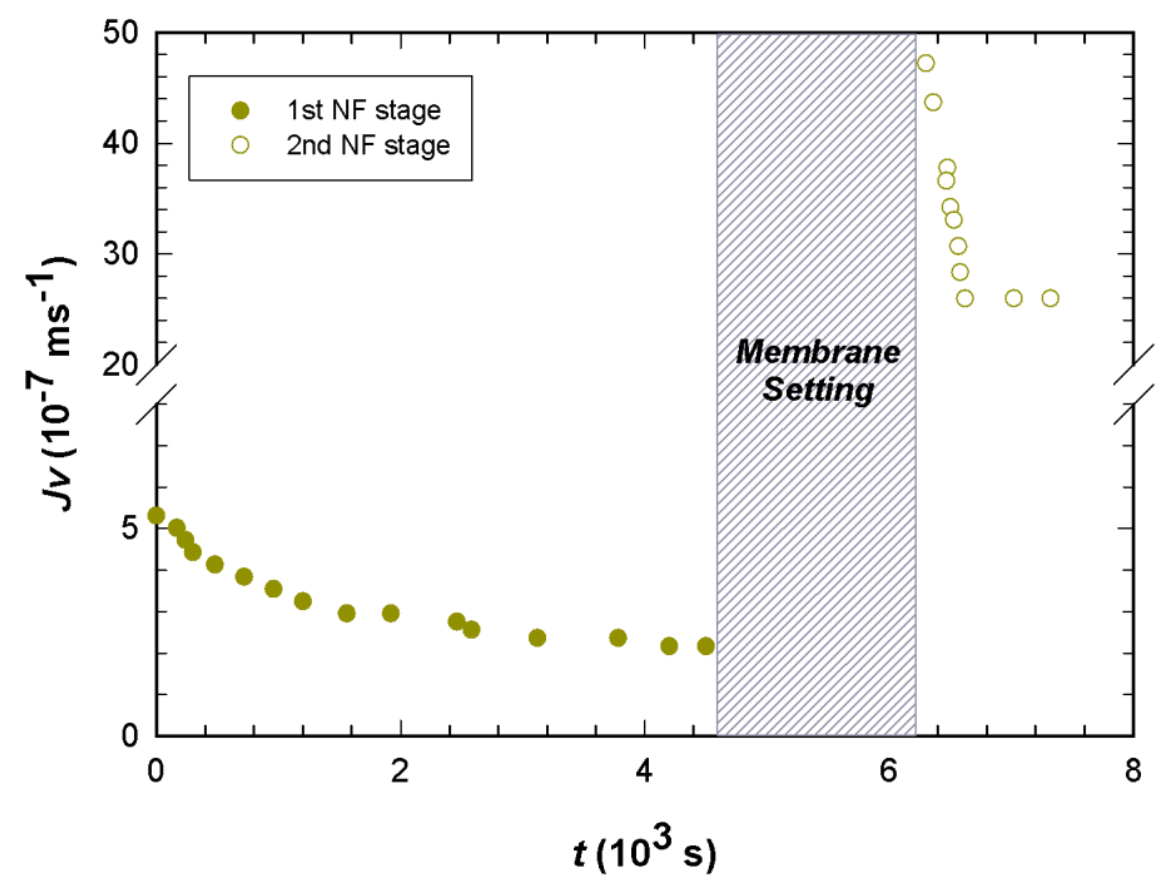

Figure 8.6 Permeate flux decrease of Verdejo grape must during the first (green filled circles) and second (white filled circles) NF stages 


\subsubsection{Analysis of the resulting musts}

The main oenological parameters of the resultant permeates and retentates were determined, for each NF stage and membrane process. These were also analyzed for the must mixtures with a lower potential alcohol content coming from the 2 membrane processes (mentioned in section 8.3.5). Results are shown in Table 8.4. Note that some parameters have not been determined for some samples because they were considered irrelevant. It can be appreciated that the mixtures $(\mathrm{P} 2+\mathrm{R} 1)$ and (P2+R1+Aromas) predict a $25^{\circ}$ reduction of the alcohol content as intended. The influence of membrane procedures on the phenolic compounds was measured in terms of the total polyphenols index (TPI) and the color index $(\mathrm{CI})$, since they are related to the color of must. Table 8.4 shows that the must blends have similar or even higher values as the control must. This means that the influence of the membrane processes on factors related with color is negligible. It is also important to analyze the total acidity (TA) of must and their mixtures since it is one of the parameters controlled to achieve an appropriate fermentation. In this sense TA should not be lower than $5 \mathrm{~g} / \mathrm{L}$ (expressed in $\mathrm{g}$ of tartaric acid $\left(\mathrm{TH}_{2}\right)$ per liter of must) otherwise it should be adjusted by adding tartaric acid before fermentation. Table 8.4 shows that the mixtures and even the original must had a TA lower than $5 \mathrm{gTH}_{2} / \mathrm{L}$ and all of them had to be adjusted. Moreover both mixtures: $(\mathrm{P} 2+\mathrm{R} 1)$ and $(\mathrm{P} 2+\mathrm{R} 1+$ Aromas $)$ had a lower TA than the original must. However the blend obtained from the PV process ( $\mathrm{P} 2+\mathrm{R} 1+$ Aromas) has a TA value that is more similar to the original must than the mixture coming from the NF process. This means that the PV process and its musts mixture allows a higher TA recovery.

The performance of the PV process was also analyzed by measuring the aroma profile of the mixtures. Results are shown and compared with the control must in Figure 8.7. It can be observed that none of the mixtures presented the same aromatic profile as the original grape must. As expected, NF enhanced the depletion of most of the aromatic compounds studied since the mixture of musts coming from this process exhibited a lower aromatic profile of them. The mixture corresponding to the process $\mathrm{PV}+2 \mathrm{NF}$ showed that PV allowed a recovery of the majority of compounds studied with the exception of benzaldehyde and 1-hexanol. Nevertheless, results advocate that PV shows an appropriate behavior for the aim of this study, but as already mentioned mass transfer during this process has to be enhanced. 


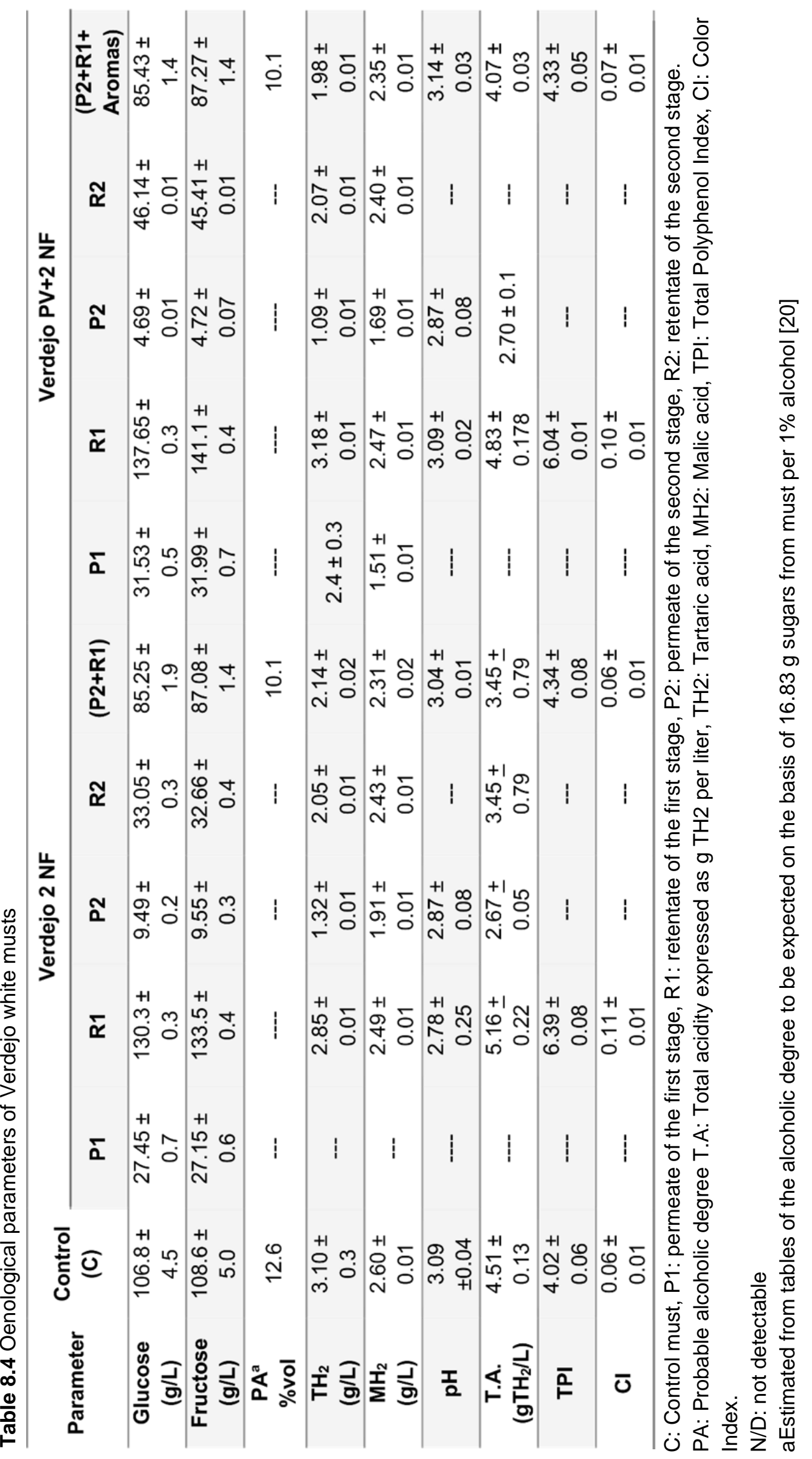




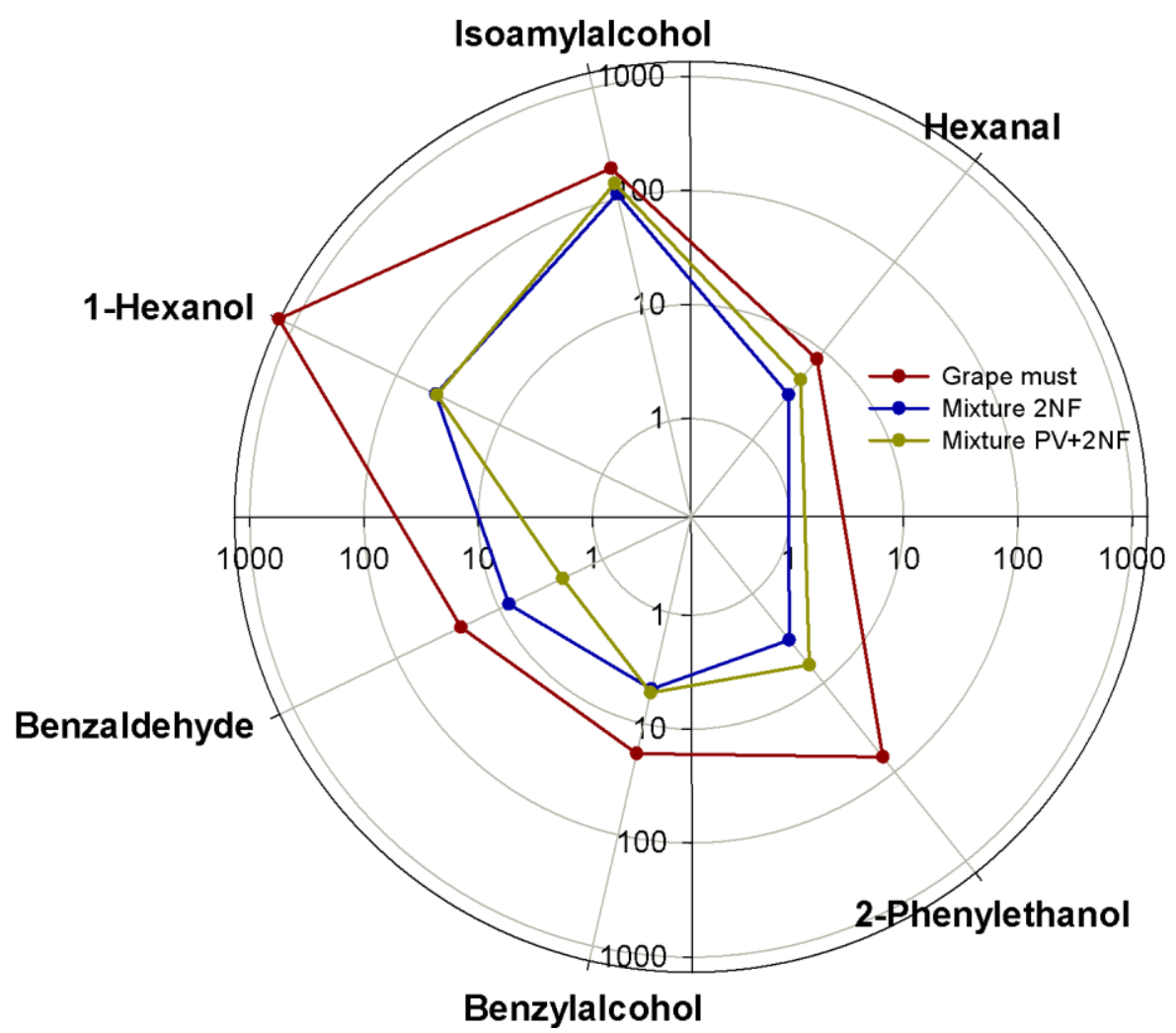

Figure 8.7 Aromatic profile of untreated grape must and the mixtures of must coming from the $2 \mathrm{NF}$ and $\mathrm{PV}+2 \mathrm{NF}$ processes before fermentation

\subsubsection{Production and chemical analysis of wines}

As mentioned in section 8.2.5, six different wines were elaborated. Two control wines ( $\mathrm{C} 1$ and $\mathrm{C} 2$ ) with a regular alcohol degree; and four low alcohol content wines: two nanofiltered (2NF1 and 2NF2) and two pervaporated -nanofiltered (PV+2NF1 and $P V+2 N F 2)$. Table 8.5 shows the results of the chemical analysis of the six wine samples.

In the case of nanofiltered samples 2NF1 and 2NF2 wines had an alcohol degree lower by $1.5^{\circ}$ and $1.4^{\circ} \%$ vol respectively in comparison to the control $\mathrm{C}$ wine. Regarding the pervaporated -nanofiltered samples, PV+2NF1 and PV+2NF2 showed an alcohol reduction by $1.7^{\circ}$ and $1.5^{\circ} \%$ vol respectively.

In terms of $\mathrm{pH}$, no significant differences between the control and filtered samples were measured. In terms of volatile acidity (VA) NF samples presented lower values but all samples had a content lower than $1 \mathrm{~g} / \mathrm{L}$ which describes an appropriate fermentation.

Regarding the parameters related to the color of wines, color index $(\mathrm{Cl})$, no significant differences were detected. But in terms of total polyphenol index (TPI) the 
control sample $\mathrm{C} 2$ presented a value much lower than $\mathrm{C} 1$. This means that the reactions during the fermentation of each control sample were different.

Table 8.5 Chemical analysis for the main oenological parameters of the white wines elaborated

\begin{tabular}{ccccccc}
\hline Paramete & \multicolumn{2}{c}{ Verdejo Control } & \multicolumn{2}{c}{ Verdejo 2NF } & \multicolumn{2}{c}{ Verdejo PV+2NF } \\
\cline { 2 - 7 } $\mathbf{r}$ & $\mathbf{C 1}$ & $\mathbf{C 2}$ & 2NF1 & 2NF2 & PV+2NF1 & PV+2NF2 \\
\hline AD & $11.90 \pm$ & $11.95 \pm$ & $10.45 \pm$ & $10.52 \pm$ & $10.25 \pm$ & 10.43 \\
(\%vol) & 0.07 & 0.01 & 0.01 & 0.01 & 0.01 & \pm 0.04 \\
& & & & & & \\
\hline \multirow{2}{*}{$\mathbf{p H}$} & $2.89 \pm$ & $2.89 \pm$ & $2.82 \pm$ & $2.79 \pm$ & $2.73 \pm$ & $2.76 \pm$ \\
& 0.01 & 0.01 & 0.02 & 0.02 & 0.01 & 0.04 \\
\hline T.A. & $7.65 \pm$ & $7.61 \pm$ & $7.28 \pm$ & $8.23 \pm$ & $7.31 \pm$ & $7.38 \pm$ \\
(gTH $/$ L) & 0.01 & 0.05 & 0.08 & 0.16 & 0.03 & 0.01 \\
\hline V.A. & $0.67 \pm$ & $0.52 \pm$ & $0.33 \pm$ & $0.28 \pm$ & $0.78 \pm$ & $0.75 \pm$ \\
(g /L) & 0.05 & 0.01 & 0.05 & 0.01 & 0.04 & 0.01 \\
\hline \multirow{2}{*}{ TPI } & $4.41 \pm$ & $4.06 \pm$ & $4.44 \pm$ & $4.22 \pm$ & $4.12 \pm$ & $4.15 \pm$ \\
& 0.04 & 0.01 & 0.06 & 0.01 & 0.08 & 0.9 \\
\hline Cl & $0.07 \pm$ & $0.08 \pm$ & $0.11 \pm$ & $0.12 \pm$ & $0.09 \pm$ & $0.09 \pm$ \\
& 0.01 & 0.01 & 0.01 & 0.01 & 0.01 & 0.01 \\
\hline
\end{tabular}

Verdejo C: White control wine, Verdejo 2NF: white wine obtained after the fermentation of the mixture $(\mathrm{R} 1+\mathrm{P} 2)$, Verdejo $\mathrm{PV}+2 \mathrm{NF}$ : white wine obtained after the fermentation of the mixture (R1+P2+Aromas)

T.A: Total acidity expressed as $g \mathrm{TH}_{2}$ per liter, $\mathrm{TH}_{2}=$ Tartaric acid, TPI: Total Polyphenol Index, Cl: Color Index

\subsubsection{Sensory characteristics of the resulting wines}

\subsubsection{Overall liking}

Consumers' overall liking scores are exhibited in Table 8.6 as the mean of this descriptor for each of the six evaluated samples. Standard deviations were relatively high, ranging from 0.78 to 1.45 , indicating some variability in consumers' evaluation for each sample. Furthermore, the same superscripts within the column indicate that, according to the Tukey`s test $(p=0.05)$, no significant differences between the samples were detected. Nevertheless scores allowed discriminating between samples. Sample $\mathrm{C} 1$ and $(\mathrm{PV}+2 \mathrm{NF} 1)$ were the most liked whereas $\mathrm{C} 2$ was the most disliked. However, no high differences were found between them, since the scores ranged from 5.00 to 6.05. This suggests that samples did not cause highly different affective reactions to the consumers. Moreover, all samples were positioned in the middle part of the scale corresponding to products classified as indifferent or slightly liked in the 9-point hedonic scale. 
Table 8.6 Mean overall liking for the six evaluated wine samples

\begin{tabular}{cc}
\hline Sample & Overall liking \\
\hline C1 & $6.05 \pm 0.78^{\mathrm{a}}$ \\
\hline C2 & $5.00 \pm 1.45^{\mathrm{a}}$ \\
\hline $2 \mathrm{NF1}$ & $5.21 \pm 1.23^{\mathrm{a}}$ \\
\hline $2 \mathrm{NF2}$ & $5.42 \pm 1.22^{\mathrm{a}}$ \\
\hline $\mathrm{PV}+2 \mathrm{NF} 1$ & $5.95 \pm 1.27^{\mathrm{a}}$ \\
\hline $\mathrm{PV}+2 \mathrm{NF2}$ & $5.42 \pm 1.17^{\mathrm{a}}$ \\
\hline
\end{tabular}

\subsubsection{Intensity scales}

Average scores for the nine evaluated sensory attributes of the six samples were subjected to principal component analysis (PCA) in order to decrease the number of results associated with the data and get a consensus representation of the samples. Results are shown in Figure 8.8, were it can be appreciated that the first principal component, PC1, accounts for $44.89 \%$ of the variability data and PC2 explains the $19.34 \%$ of the data variance. According to Figure 8.8 wines could be separated into three groups. First, sample 2NF1 was located apart from the rest of samples and was characterized by high odor intensity. Meanwhile, samples C1, 2NF2 and PV+2NF2 were located in the group of wines perceived as bitter, fruity and fennel. Whereas samples PV+2NF1 and C2 were perceived as herbaceous and more persistent in mouth and acid. Specially, sample C2 was located at the highest acid intensity and this may be the reason why this sample corresponded to the most disliked one as shown in Table 8.6.

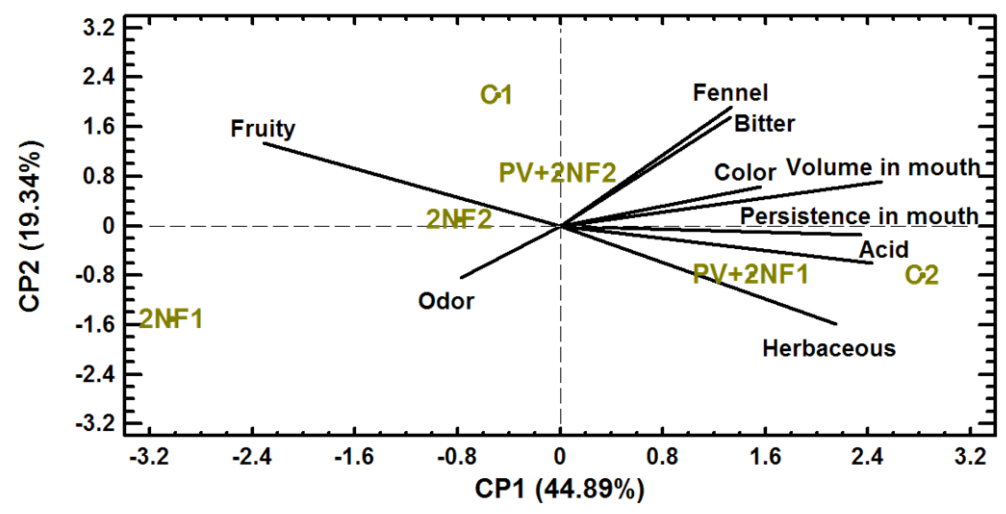

Figure 8.8 Representation of the six wine samples in the first two dimensions of the PCA plot of mean scores from intensity scales. 


\subsubsection{Projective mapping}

Figure 8.9 represents the location of wine samples in the first two dimensions of the MFA of the projective mapping data. The first dimension of the MFA accounted for $28.67 \%$ and the second for $22.24 \%$ of the total variance of the experimental data. MFA shows that samples can be separated into 2 main groups. One group is composed of samples $\mathrm{C} 1, \mathrm{PV}+2 \mathrm{NF} 2$ and $2 \mathrm{NF} 1$ being all samples located in the negative values of both dimensions. The second group is composed of samples C2, PV+2NF1 and 2NF2 even though they are located relatively apart from each other. It is important to see that in both groups the low alcohol samples: PV+2NF2 and 2NF1 in the first group and $\mathrm{PV}+2 \mathrm{NF} 1$ and $2 \mathrm{NF} 2$ in the second, were found more similar between them. It is also important to analyze that, in both groups; the samples corresponding to the PV experiments are located nearer to the control samples than the ones coming from the NF tests. This suggests that consumers found PV samples more similar to the control wines than NF samples.

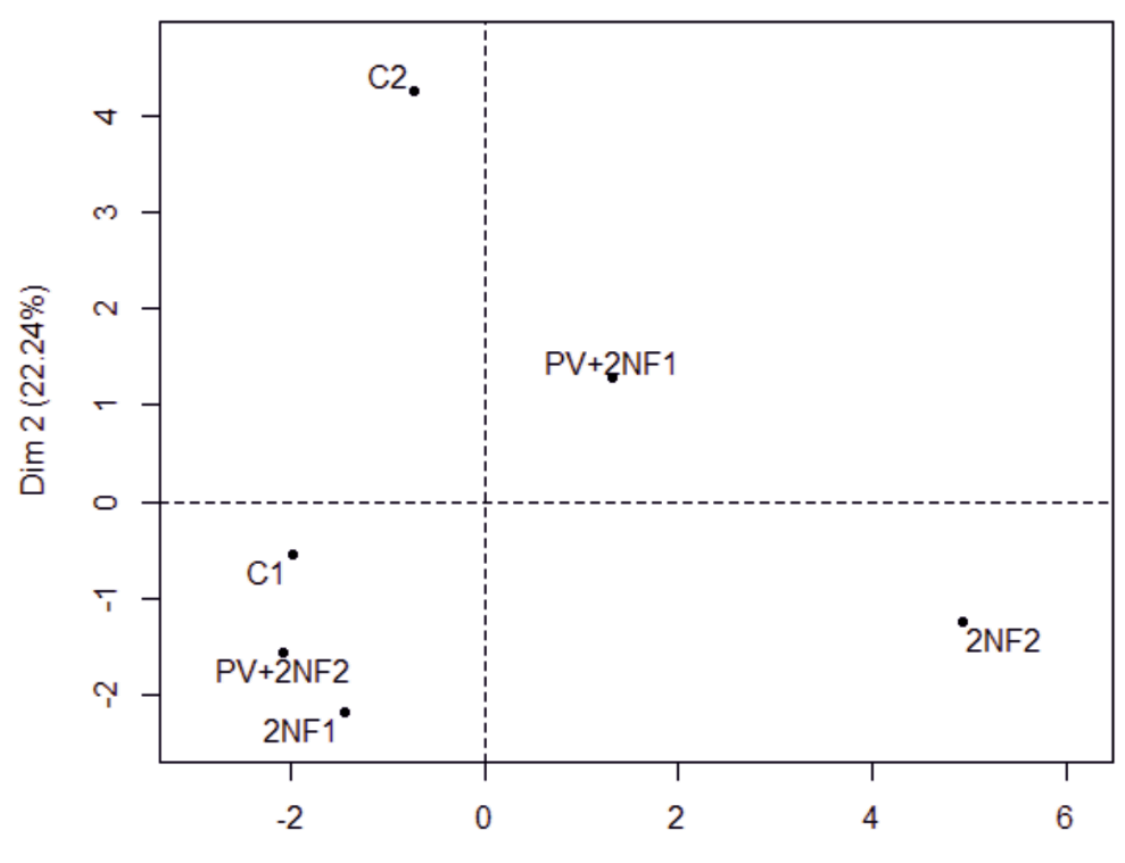

$\operatorname{Dim} 1(28.67 \%)$

Figure 8.9. Representation of the six wine samples in the first two dimensions of the MFA plot of data from projective mapping

\subsubsection{Aromatic profile of the resulting wines}

The transformation of must into wine trough alcoholic fermentation alters considerably the chemical composition of the medium. The alcohol produced by the 
fermentation of sugars in the must causes both qualitative and quantitative changes in its chemical composition.

In our case the difference in sugar content of the mixtures and control musts affects the production of one of the major compounds, ethanol. This compound is also associated with the formation of various compounds that provide aroma characteristics to wine. For example ethylesters are produced during fermentation by the reaction of ethanol with fatty acids.

Moreover, it is not simple to compare the aromatic profile of the six wines elaborated since not only the alcohol content of the blends was different, also each fermentation was carried out in a different vessel. Therefore, the aromas of the different volatile compounds generated combine to create a new aroma that makes each wine unique.

Thus, in order to compare the aroma profile of the wines obtained by each membrane process, the average aromatic content of the filtrated wines were compared with the most liked control wine (C1). The comparison of all the compounds identified in the three wine samples is beyond the scope of this study. Therefore, only 14 of the 23 compounds were selected for the assessment of the wines obtained. Results are shown in Figure 8.10. Note that the peak areas are normalized (100) to the total peak area excluding ethanol.

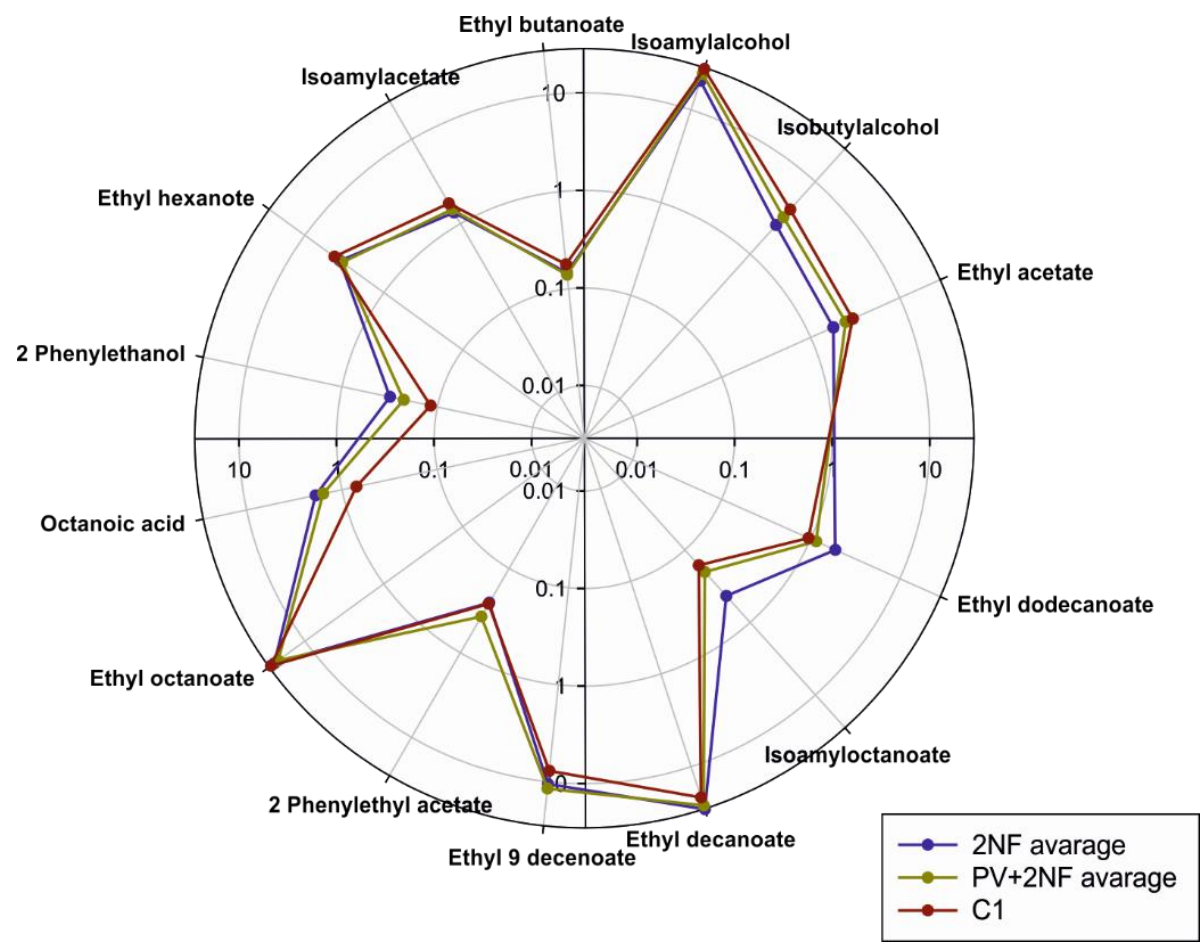

Figure 8.10 Aromatic profile of the resulting average wine samples expressed in normalized peak areas $(A \%)$ to the total peak area excluding ethanol 
Results show that the average wine coming from the PV experiments ( $P V+2 N F$ average have a more similar aromatic profile to the control wine (C1) for eight of the compounds that compose it. Moreover, this occurs mainly with low molecular weight alcohols and esters (see Table 8.7) with the exception of ethyldodecanoate. The concentration of higher molecular weight components (such as higher ethylesters) occurs during the last stages of alcoholic fermentation and is more influenced by reactions of byproducts during this process. Lower alcohols and esters are produced during the initial phase of fermentation and are more related with aroma precursors in grape juice which are recovered during PV and can be lost during NF. Moreover, as shown in Figure 8.7 PV allowed the recovery of isoamylalcohol and 2-phenylethanol and it can be expected that it allowed also the recovery of similar compounds as is the case of Isobutyl alcohol. In this sense, it is logical that the wine (PV+2NF average) has a more similar content of these compounds than (2NF average) when compared to $C 1$. Figure 8.10 also shows that (PV+2NF average) has a higher content of aromas related to the mentioned precursors such as isoamylacetate, isoamyloctanoate and phenylethylacetate.

Table 8.7 Characteristic wine aroma components

\begin{tabular}{|c|c|c|c|}
\hline Compound & $\begin{array}{c}\text { Molecular } \\
\text { weight }\left(\mathrm{g} \mathrm{mol}^{-1}\right)\end{array}$ & $\begin{array}{l}\text { Boiling Point } \\
\text { (으) }\end{array}$ & $\begin{array}{l}\text { Aromatic } \\
\text { descriptor }\end{array}$ \\
\hline Ethyl acetate & 88.11 & 77 & Ethereal -fruity \\
\hline Isobutylalcohol & 74.12 & 108 & $\begin{array}{c}\text { Nail polish, } \\
\text { pungent }\end{array}$ \\
\hline Isoamylalcohol & 88.15 & 130 & Malty, pungent \\
\hline Ethylbutanoate & 116.16 & 119 & Fruity, sweet \\
\hline Isoamylacetate & 129.18 & 215 & Banana \\
\hline Ethyl hexanoate & 144.21 & 166 & Fruity, pleasant \\
\hline 2 Phenylethanol & 122.16 & 219 & Rose, spicy \\
\hline Octanoic acid & 144.21 & 237 & Rotten fruit \\
\hline Ethyl octanoate & 172.26 & 206 & Ripe fruit \\
\hline 2 Phenylethylacetate & 164.2 & 238 & Rose, floral \\
\hline Ethyl 9 decenoate & 198.30 & 249 & Rose \\
\hline Ethyl decanoate & 200.32 & 245 & Fruity \\
\hline Isoamyloctanoate & 214.34 & 267 & Oily \\
\hline Ethyl dodecanoate & 228.37 & 269 & $\begin{array}{l}\text { Sweet, waxy, } \\
\text { fruity }\end{array}$ \\
\hline
\end{tabular}


The chemical analysis of the aromas also allowed to evaluate the consumer sensory test. As shown in Figure 8.8 C1 and the PV wines were located in the regions perceived by the consumers as fruity, herbaceous and fennel. This last descriptor is related with herbaceous, sweet notes, similar to anise. These agrees with the aromatic descriptors (see Table 8.7) characteristic of these samples such as Isoamylalcohol, Ethylacetate, Ethyldodecanoate, Octanoicacid, Phenylethanol, Isoamylacetate and Isoamyloctanoate.

\subsection{Conclusions}

After the assessment of the different membrane processes studied in this work, the main following conclusions can be raised:

- The new experimental set up allowed the reduction of the NF time necessary for the intended sugar control.

- The mixture of musts ( $\mathrm{P} 1+\mathrm{R} 2+$ aromas) corresponding to the process $\mathrm{PV}+2 \mathrm{NF}$ showed an aroma content more similar to the original grape must with the exception of Benzaldehyde and 1-Hexanol.

Regarding the wines produced, the following conclusions can be made:

- Both of the membrane processes studied here for sugar control in grape juice allowed the partial reduction of alcohol in the resulting wine.

- Consumers' overall liking scores showed that Sample C1 and (PV+2NF1) were the most liked.

- Projective mapping (Napping ${ }^{\circledR}$ ) results exhibited that consumers found the wine samples corresponding to the PV tests more similar to the control samples.

- Analysis of the aroma compounds showed that in comparison to the most liked control wine, wines coming from the PV experiments had a more similar aromatic profile than the ones coming only from the NF tests.

All in all it can be concluded that among the membrane processes assessed in this work, the combination of PV and a 2 stage NF process presented the best results for the elaboration of a full flavored low alcohol content wine. Nevertheless mass transfer during the PV process needs to be enhanced. This can be presumably achieved by increasing the time of PV. Also a higher feed tangential flow or feed 
pressure should improve the aroma transfer if care was taken to avoid exceeding the maximal pressure drop through SWM recommended by the manufacturer.

\subsection{Acknowledgments}

Authors would like to thank the "Ministerio de Ciencia e Innovación (MCINN)" for the financial support of this work within the frame of the "Plan Nacional de I+D+I" through the research projects, CTQ2012-31076 and MAT2011-25513. We also are grateful to the projects: VA-248U13 of the Junta de Castilla y León.

C. Salgado wants to thank the Spanish Ministry of Education for the grant they gave to her within the frame of the "Plan Nacional de Investigación Científica, Desarrollo e Innovación Tecnológica 2008-2011" (FPU grant: AP2010-5769) to complete her PhD.

Authors also want to thank Miguel Angel García Esteban for his support during the fermentation procedures and wine analysis and the consumers that participated in the sensory tests. 


\subsection{Nomenclature}

Roman

$A_{m}$

Membrane active area $\left(\mathrm{m}^{2}\right)$

$\mathrm{C}_{\mathrm{F}, \mathrm{j}}$

Mass concentration of the i-th compound in the feed $\left(\mathrm{kgm}^{-3}\right)$

$\mathrm{C}_{\mathrm{P}, \mathrm{j}}$

Mass concentration of the i-th compound in the permeate $\left(\mathrm{kgm}^{-3}\right)$

$\mathrm{J}_{\mathrm{i}}$

Permeate flux of the i-th compound $\left(\mathrm{gh}^{-1} \mathrm{~m}^{2}\right)$

$J_{v}$

Volumetric permeate flux per unit of area through the membrane $\left(\mathrm{m} \mathrm{s}^{-1}\right)$

Greek

$\alpha_{i, j}$

Selectivity for the i-th compound towards the j-th compound.

(dimensionless).

$\beta_{i} \quad$ Mass concentration enrichment factor (dimensionless) 


\subsection{References}

[1] C. Lasanta, I. Caro, J. Gómez, L. Pérez, The influence of ripeness grade on the composition of musts and wines from Vitis vinifera cv. Tempranillo grown in a warm climate, Food Research International, 64 (2014) 432-438.

[2] R. Mira de Orduña, Climate change associated effects on grape and wine quality and production, Food Research International, 43 (2010) 1844-1855.

[3] N. Garcia-Martin, S. Perez-Magarino, M. Ortega-Heras, C. Gonzalez-Huerta, M. Mihnea, M.L. Gonzalez-Sanjose, L. Palacio, P. Pradanos, A. Hernandez, Sugar reduction in white and red musts with nanofiltration membranes, Desalination and water treatment, 27 (2011) 167-174.

[4] I. Kiss, G. Vatai, E. Bekassy-Molnar, Must concentrate using membrane technology, Desalination, 162 (2004) 295-300.

[5] A. Versari, R. Ferrarini, G.P. Parpinello, S. Galassi, Concentration of Grape Must by Nanofiltration Membranes, Food and Bioproducts Processing, 81 (2003) 275-278.

[6] C. Salgado, L. Palacio, F.J. Carmona, A. Hernández, P. Prádanos, Influence of low and high molecular weight compounds on the permeate flux decline in nanofiltration of red grape must, Desalination, 315 (2013) 124-134.

[7] C.M. Salgado, L. Palacio, P. Prádanos, A. Hernández, C. González-Huerta, S. Pérez-Magariño, Comparative study of red grape must nanofiltration: Laboratory and pilot plant scales, Food and Bioproducts Processing, 94 (2015) 610-620.

[8] T. Schäfer, Recovery of wine-must aroma by pervaporation, in, Universidade Nova de Lisboa, Portugal, 2002.

[9] C.C. Pereira, C.P. Ribeiro Jr, R. Nobrega, C.P. Borges, Pervaporative recovery of volatile aroma compounds from fruit juices, Journal of Membrane Science, 274 (2006) $1-23$.

[10] H.O.E. Karlsson, G. Tragardh, Applications of pervaporation in food processing, Trends in Food Science \& Technology, 7 (1996) 78-83.

[11] C. Brazinha, D.S. Barbosa, J.G. Crespo, Sustainable recovery of pure natural vanillin from fermentation media in a single pervaporation step, Green Chemistry, 13 (2011) 2197-2203.

[12] C. Salgado, F.J. Carmona, L. Palacio, P. Prádanos, A. Hernández, Evaluation of nanofiltration membranes for sugar reduction in red grape must, in: EUROMEMBRANE 2012, London, UK, 2012.

[13] S.M. Rocha, P. Coutinho, A. Barros, I. Delgadillo, M.A. Coimbra, Establishment of the varietal volatile profile of musts from white Vitis vinifera $L$. varieties, Journal of the Science of Food and Agriculture, 87 (2007) 1667-1676. 
[14] E. López-Tamames, N. Carro-Mariño, Y.Z. Gunata, C. Sapis, R. Baumes, C. Bayonove, Potential Aroma in Several Varieties of Spanish Grapes, Journal of Agricultural and Food Chemistry, 45 (1997) 1729-1735.

[15] E.S. Palomo, M.C. Díaz-Maroto, M.A.G. Viñas, A. Soriano-Pérez, M.S. PérezCoello, Aroma profile of wines from Albillo and Muscat grape varieties at different stages of ripening, Food Control, 18 (2007) 398-403.

[16] J. Hidalgo - Togores, Calidad del vino desde el viñedo, Mundi- Prensa, Madrid, 2006.

[17] C.A. Zuritz, E.M. Puntes, H.H. Mathey, E.H. Pérez, A. Gascón, L.A. Rubio, C.A. Carullo, R.E. Chernikoff, M.S. Cabeza, Density, viscosity and coefficient of thermal expansion of clear grape juice at different soluble solid concentrations and temperatures, Journal of Food Engineering, 71 (2005) 143-149.

[18] C.P. Koutsou, S.G. Yiantsios, A.J. Karabelas, Direct numerical simulation of flow in spacer-filled channels: Effect of spacer geometrical characteristics, Journal of Membrane Science, 291 (2007) 53-69.

[19] N. García-Martín, S. Perez-Magariño, M. Ortega-Heras, C. González-Huerta, M. Mihnea, M.L. González-Sanjosé, L. Palacio, P. Prádanos, A. Hernández, Sugar reduction in musts with nanofiltration membranes to obtain low alcohol-content wines, Separation and Purification Technology, 76 (2010) 158-170.

[20] J. García - Barceló, Técnicas Analíticas Para Vinos, in, GAB, Barcelona, Spain, 1990.

[21] OIV, Compendium of International Methods of Wine and Must Analysis, OIV, Paris, 2011.

[22] A. Amerine, C.S. Ough, Análisis de vinos y mostos, 1st ed., Acribia Zaragoza. Spain, 1976.

[23] J. Zhang, L. Li, N. Gao, D. Wang, Q. Gao, S. Jiang, Feature extraction and selection from volatile compounds for analytical classification of Chinese red wines from different varieties, Analytica Chimica Acta, 662 (2010) 137-142.

[24] G. Ares, P. Varela, G. Rado, A. Giménez, Identifying ideal products using three different consumer profiling methodologies. Comparison with external preference mapping, Food Quality and Preference, 22 (2011) 581-591.

[25] J. Pagès, Collection and analysis of perceived product inter-distances using multiple factor analysis: Application to the study of 10 white wines from the Loire Valley, Food Quality and Preference, 16 (2005) 642-649

[26] R.D.C. Team, R: A Language and Environment for Statistical Computing, in, R Foundation for Statistical Computing, Vienna, Austria. ISBN 3-900051-07-0, 2007. 


\subsection{Supplementary material}

The following is the supplementary information provided for this work.

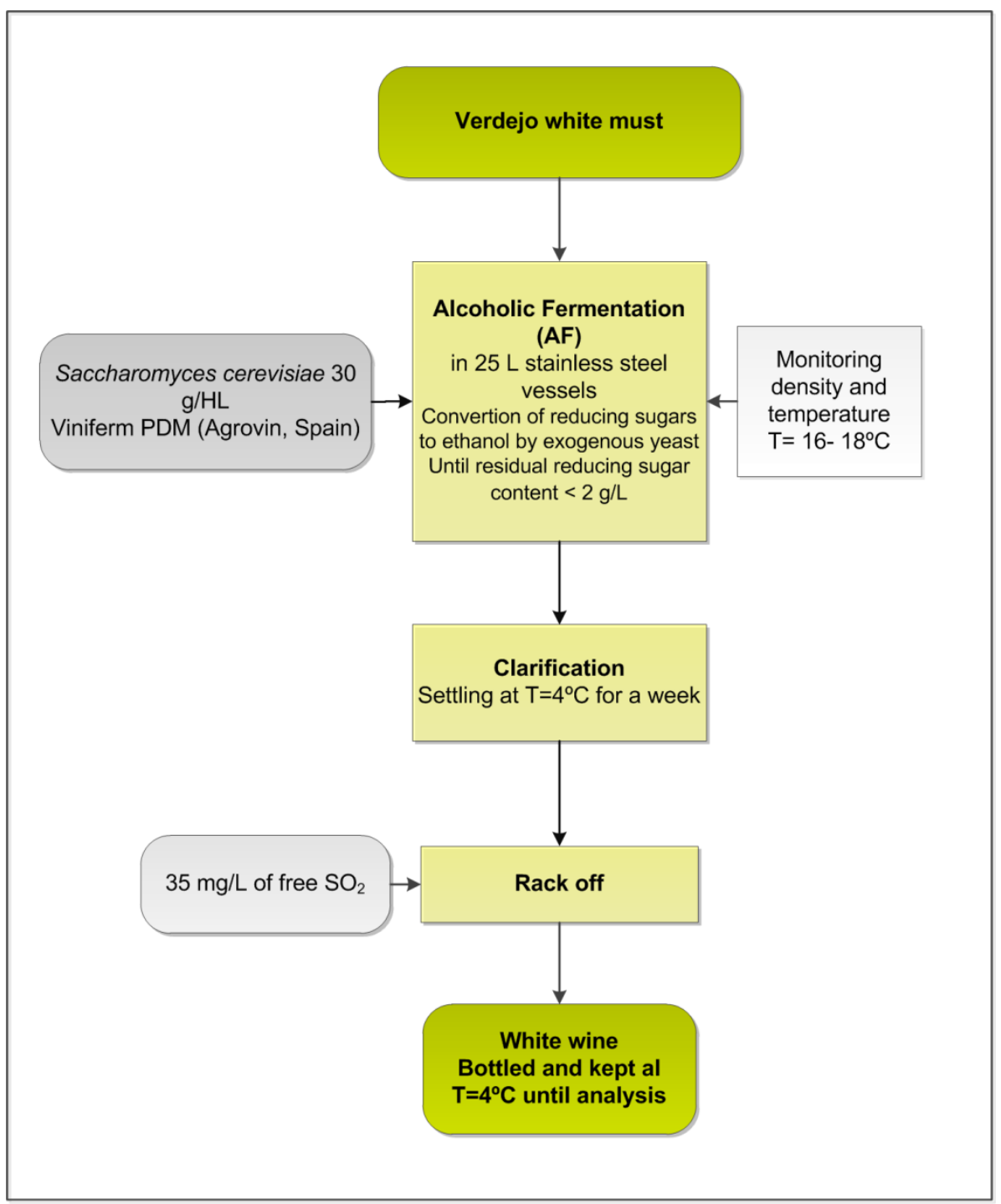

Figure S8.1 Traditional winemaking procedure for white wines 
SECTION V. MAIN CONCLUSIONS \& FUTURE WORK 



\section{Conclusions}





\section{Conclusions}

The scope of the work described in the present $\mathrm{PhD}$ thesis is to optimize a membrane process for the appropriate control of fermentable sugar of grape must aiming to produce full flavored low alcohol content wines. In general, this research has been focused on the development of a complete membrane process capable of solving the problems caused by climate change on grapes composition. This process should be able to help winemakers to keep the elaboration of wines with a controlled alcohol content, which at the same time is liked and accepted by consumers.

From the different studies carried out for this purpose, several conclusions may be raised.

Regarding the study of reduction of the nanofiltration permeate volume flux $\left(J_{v}\right)$ due to fouling, resistances $\left(R_{j}\right)$ and osmotic pressure generated during the nanofiltration of grape must a method was proposed. This one allowed the individual analysis of the influence of the different molecular weight compounds characteristic of grape juice. The results proved that high molecular weight compounds (HMW) have more influence on the permeate flux decrease since they are the main responsible of the fouling phenomenon (cake filtration fouling mechanism), while low molecular weight compounds (LMW) contribute to the flux decay mostly through an increase of osmotic pressure during the process.

Moreover, the method was tested using three different nanofiltration membranes. This allowed a systematical analysis and comparison of the performance and fouling of these membranes during must nanofiltration. Here, it was proven that for the three of them:

- the kinetics of fouling when HMW compounds were present included three consecutive steps: pore blocking followed by cake deposition and an increase in compression until arriving to compaction

- it was observed that, the maximum resistances caused by HMW ( $\left.R_{\text {HHMW }}\right)$ agreed fairly well with the beginning of the third fouling mechanism, where the cake starts to be compacted

- the evolution of the effective pore radii evaluated from must retention showed that for long filtration periods they tend to a similar final effective pore size which converges in the pore size determined by the cake deposit and its compaction.

According to this study it could also be concluded that the ideal NF membrane for the intended process would, have a retention of the main sugars of about $50 \%$. 
Also, it should have low affinity for HMW since they are the main responsible of flux decrease due to fouling. Besides, the process should be designed to operate at low concentration polarization conditions in order to reduce the effects of osmotic pressure observed. The latter should be achieved working at the highest possible recirculation flow and also using effective turbulence promoters inside the membrane module.

The design of a pilot plant-scale experimental set up that would simultaneously allow an adequate control, short filtration times and volume, promoted several results. First, the systematic study and comparison of different nanofiltration membranes helped the selection of the most appropriate spiral wound module (SWM) in terms of desired sugars retention and less fouling. Moreover, the tests carried out aiming to analyze mass transfer and membrane fouling in the SWM allowed assessing the influence of spacers in it. Results showed that the flow destabilization and eddy promotion caused by spacers mitigated the rate at which the cake thickens and compacts on the membrane surface. The latter caused a less-sharp permeate flux decrease with an almost constant sugars rejection and small osmotic pressure differences.

The results of the experiments conducted during the first vintage promoted the selection of the most appropriate NF technique. Results showed that for the intended sugar reduction and wine elaboration a 2-stage NF process is the best choise. This is because the mixture of the retentate of the first stage $(R 1)$ with the permeate of the second (P2) allowed not only the appropriate control of sugars but it also promoted a higher recovery of HMW (i.e. polyphenols) and minimized volume losses. This 2-stage process was improved in ulterior experiments carried out during the second vintage. This was achieved designing a device with two SWM arranged in parallel and increasing the recirculation flow. The new set up reduced the NF time required for sugar reduction using the 2-stage process.

The studies of the resulting impairment of the aroma and flavor quality of the final wine allowed the analysis of the use of pervaporation (PV) for the recovery of the primary aromas of must before NF.

Experiments at laboratory scale using PV membranes coated with two of the most used polymers: polydimetylsiloxane (PDMS) and polyetherblockamide (PEBA) promoted different results. First it showed the feasibility of the use of these membranes for the recovery of several aroma compounds characteristic of natural beverages. Moreover, it was observed during aqueous model solution experiments that both membranes have higher selectivity for aldehydes than for alcohols. But, both 
membranes showed a different permeation behavior during PV of grape juice tests changing to a higher selectivity for alcohols. This means that probably aldehydes have stronger interactions than alcohols with the rest of the components of grape must. Even though both membranes exhibited similar performance, PDMS showed the best permeation behavior to all compounds of interest and for both feeds. It is also important to mention that one of the major disadvantages of the PV process proposed is the low operating temperature. Although it reduces the mass transfer through the membrane of the target compounds, it is required to prevent the evaporation of these compounds in the tank. Also higher temperatures would promote undesirable reactions in the juice such as spontaneous fermentation or spoilage and the formation of side aromas.

Aroma depletion was evaluated at a higher scale (i.e. pilot plant) in the second vintage using a PDMS based SWM. The comparison of the results obtained at both scales showed that in terms of permeate flux, enrichment factor and selectivity of the PV SWM the values were remarkably lower than those obtained at laboratory scale. In spite of this, the analysis of the aroma compounds of the musts mixtures and resulting wines, showed that those coming from the PV and NF processes had an aroma profile more similar to the control ones. Moreover, consumers' overall liking scores showed that wines coming from PV and NF processes were more preferred than those coming only from NF experiments. This leads to the conclusion of the feasibility of the use of PV for aroma recovery of grape juice for the elaboration of a full flavored low alcohol content wine.

As the main conclusion of the present work it can be said that among the different processes studied here, the best one is the combination of pervaporation for aroma recovery followed by a 2-stage nanofiltration procedure for sugar reduction. This combination will provide a solution to the climate-change related effects detected the winemaking industry 



\section{Future directions}





\section{Future directions}

In accordance to the results obtained in this work the following issues could be considered for ulterior research and development activities in order to enhance the membrane process proposed:

- Study of an online cleaning procedure for the nanofiltration membrane in order to enhance the productivity and yield of the process by increasing the volume of must to be filtered. An interesting process could be the use of a high flux backflush system for the removal of the cake deposited on the membrane surface.

- Detailed study of mass transfer and hydrodynamics in the PV SWM in order to enhance the permeation of primary aroma compounds in grape must.

- Design of a new PV set up capable of operate at higher temperatures inside the module (around $30^{\circ} \mathrm{C}$ ) without increasing the temperature of the feed. This can be presumably achieved with two heat exchangers at the ends of the PV module. A heater should be placed before the module in order to heat the feed and a cooler in the retentate loop aiming to cool the retentate before it returns to the feed tank. 
